University of Louisville

ThinkIR: The University of Louisville's Institutional Repository

Electronic Theses and Dissertations

8-2015

\title{
Globalization and inter-local cooperation : the mediating roles of local contexts in the global North and South.
}

\author{
Eric Yankson \\ University of Louisville
}

Follow this and additional works at: https://ir.library.louisville.edu/etd

Part of the Urban Studies Commons

\section{Recommended Citation}

Yankson, Eric, "Globalization and inter-local cooperation : the mediating roles of local contexts in the global North and South." (2015). Electronic Theses and Dissertations. Paper 2240.

https://doi.org/10.18297/etd/2240

This Doctoral Dissertation is brought to you for free and open access by ThinkIR: The University of Louisville's Institutional Repository. It has been accepted for inclusion in Electronic Theses and Dissertations by an authorized administrator of ThinkIR: The University of Louisville's Institutional Repository. This title appears here courtesy of the author, who has retained all other copyrights. For more information, please contact thinkir@louisville.edu. 


\title{
GLOBALIZATION AND INTER-LOCAL COOPERATION: THE MEDIATING ROLES OF LOCAL CONTEXTS IN THE GLOBAL NORTH AND SOUTH
}

\author{
By
}

\author{
Eric Yankson \\ B.A., University of Ghana-Legon, 2006 \\ M.Sc., University of Alabama, 2011

\begin{abstract}
A Dissertation
Submitted to the Faculty of the

College of Arts and Sciences of the University of Louisville

In Partial Fulfillment of the Requirements

For the Degree of
\end{abstract} \\ Doctor of Philosophy in Urban and Public Affairs \\ Department of Urban and Public Affairs \\ University of Louisville \\ Louisville, Kentucky
}

August, 2015 
Copyright (C) 2015 by Eric Yankson

All Rights Reserved 



\title{
GLOBALIZATION AND INTER-LOCAL COOPERATION: THE MEDIATING ROLES OF LOCAL CONTEXTS IN THE GLOBAL NORTH AND SOUTH
}

\author{
By
}

\author{
Eric Yankson \\ B.A., University of Ghana-Legon, 2006 \\ M.Sc., University of Alabama, 2011
}

A Dissertation Approved on

May 8, 2015

By the following Dissertation Committee:

Hank V. Savitch, Ph.D. (Chair)

Steven G. Koven, Ph.D. (Member)

Margath Walker, Ph.D. (Member)

Charles E. Ziegler, Ph.D. (Member) 


\section{ACKNOWLEDGEMENTS}

I wish to express my profound gratitude to the Almighty God because I could not have come this far in my academic pursuits without His guidance and protection. He is the author of my life; and I owe my existence to Him. I am also grateful to my dissertation supervisor, Dr. Hank V. Savitch, for his input, guidance, and penchant for excellence which have contributed immensely to the quality of this work. As a distinguished scholar and mentor, Dr. Savitch inspires me greatly; and I am humbled by the opportunity to have worked with him. Moreover, I wish to thank Dr. Steven G. Koven, a member of my dissertation committee, for bringing his wealth of experience, knowledge, and insights to bear on my research through his comments and suggested changes. I am also thankful to Dr. Margath Walker for her great contributions as a member of my dissertation committee; particularly her comments and the invaluable knowledge gained from her qualitative methods class, which have enriched the quality of my research. I wish to thank Dr. Charles E. Ziegler, also a member of my dissertation committee, for his insightful comments, suggestions, and inputs.

I am grateful to a number of persons (currently or previously affiliated with the Department of Urban and Public Affairs at the University of Louisville) for contributing in diverse ways to the success of my studies and research. Specific thanks go to Dr.

David Imbroscio, Dr. David Simpson, Dr. Steven C. Bourassa, Mr. Yani Vozos, Ms. Juli Wagner, Ms. Patty Sarley, and Mr. Chris Peveler. I also wish to thank all my professors 
in both the doctoral and master's programs (especially Dr. Seth Appiah-Opoku) for their advise, guidance, and support in the course of my academic endeavors.

The interviews carried out in connection with this study would not have been possible without the respondents and facilitator. Thus, I wish to express my heartfelt gratitude to the various business/investment and local officials in Chicago and Accra who graciously took time off their busy schedules to be interviewed in connection with this research. I also thank my sister (Marian Yankson) for her role in arranging and facilitating my interviews in Accra. I am grateful to the organizations in Chicago which provided me with data/information in connection with this study. I also thank some foreign/diplomatic missions in Ghana for responding favorably to my request for data in relation to this research.

I wish to thank my parents, Anthony and Grace Yankson, for inculcating in me the love for knowledge, imbibing me with self-confidence, and inspiring me to aspire to greater laurels. My siblings (Cynthia, Ernest, Anthony, and Marian Yankson) and cousin (Kojo Baiden) have also been strong pillars of support; and I am grateful to them. I am thankful to my close friends (Naa Ansaa, Adjoa Basintale, Charles Kaye-Essien, Emmanuel Frimpong Boamah, Will and Maria Drake, John and Mabel Micah, Worlali Senyo, James Malm, Stephen Adu, and Emeka Nwafor), my contact families in Louisville (Mike and Joy Hagan; Ron and Nancy Aguiar) and all loved ones whose efforts and encouragement one way or the other have contributed to the success of my studies and research. 


\begin{abstract}
GLOBALIZATION AND INTER-LOCAL COOPERATION: THE MEDIATING ROLES OF LOCAL CONTEXTS IN THE GLOBAL NORTH AND SOUTH
\end{abstract}

Eric Yankson

May 8, 2015

There is an area of scholarly interest which argues that globalization brings about the need for collaboration among local governmental units in order to address common challenges. According to Brenner and Swyngedouw, globalization also results in rescaling because it redefines spatial and political frameworks, and thus transfers powers to actors beneath and beyond the nation-state. Inter-local cooperation is a form of rescaling since it reconfigures territorial boundaries and results in either decentralization or centralization. This research explores the implications of globalization for interjurisdictional collaboration, as modified by local factors. It focuses on two city-regions in the Global North and South respectively (i.e. Chicago, Illinois and Accra, Ghana). Specific research questions are: (a) What is the nature of globalization in Chicago and Accra given their unique local contexts?; (b) How do local factors mediate the implications of globalization for regional cooperation in the two metropolitan areas?; (c) What are the ramifications of globalization for rescaling in the two city-regions, given their respective local contexts? 
The qualitative inquiry is exploratory in nature and relies on secondary data, discourse analysis, and interviews. It finds that because of their different levels of strategic importance in the global economy, Chicago serves as a headquarter location for multinational corporations, while Accra plays host to subsidiaries or local branches of such corporate entities. As a result of Chicago's strong private sector and history of civic engagement, globalization has resulted in a fluid, voluntary, and informal approach to regionalism characterized by resistance to annexation and political fragmentation. In the case of Accra, governmental institutional restructuring associated with the global era has created an administrative, directed, and formal approach to regionalism, associated with territorial expansion and centralized bureaucracy. The research shows existing works by scholars such as Brenner and Swyngedouw do not sufficiently account for the mediating roles of local contexts, particularly in the Global South, when analyzing the implications of globalization for regionalism. 


\section{TABLE OF CONTENTS}

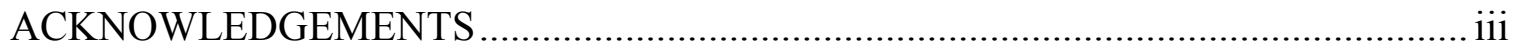

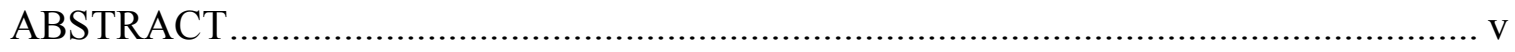

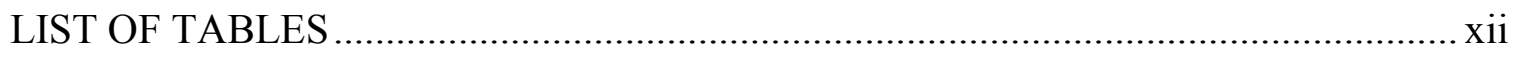

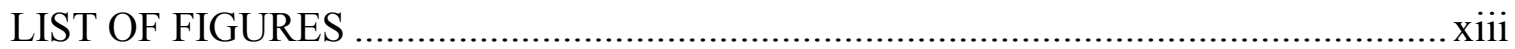

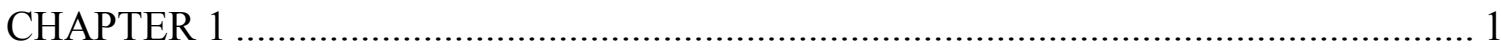

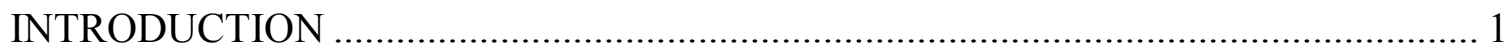

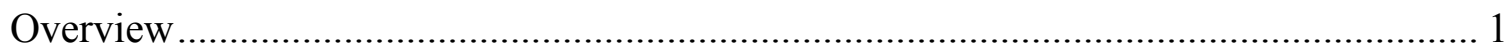

1.1 Globalization, Nations, and Cities ..................................................................... 4

1.2 Inter-Local Cooperation, Governance, and Government....................................... 8

1.3 Globalization, Inter-Local Cooperation, and the Roles of Local Factors .................. 10

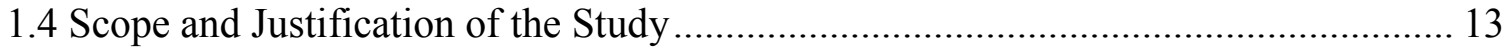

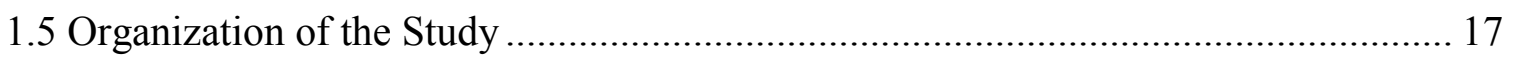

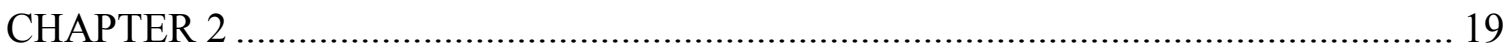

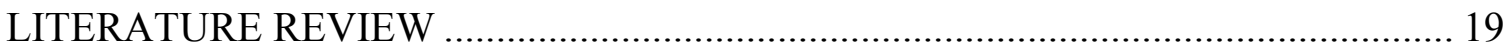

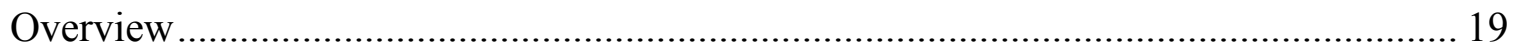

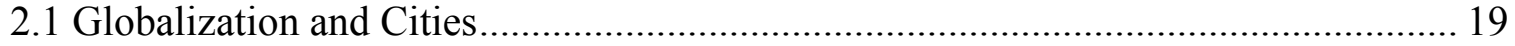

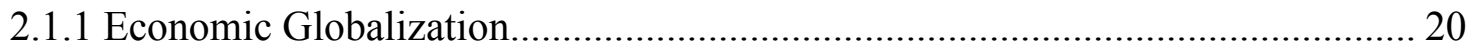

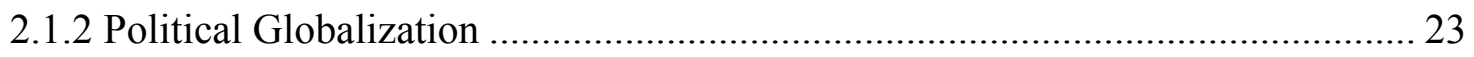

2.1.3 Global City Model ......................................................................................... 26 


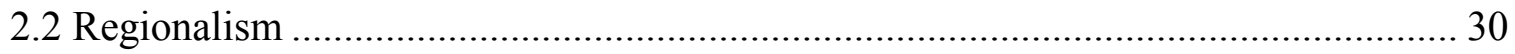

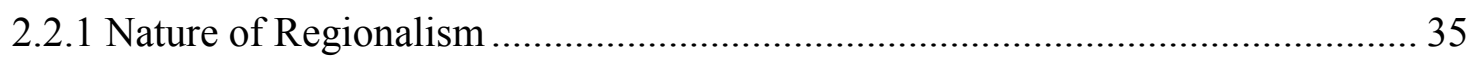

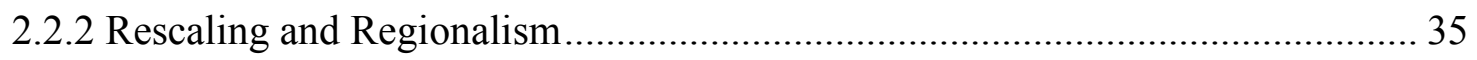

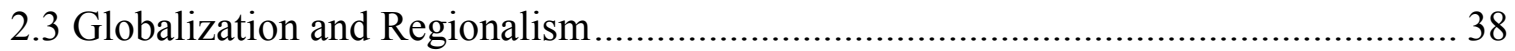

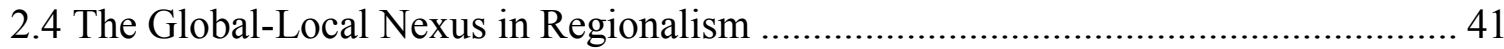

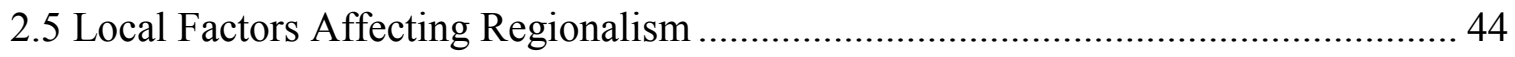

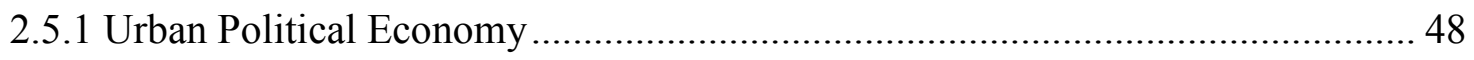

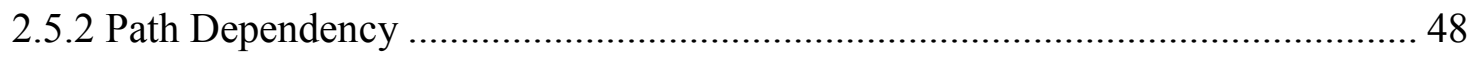

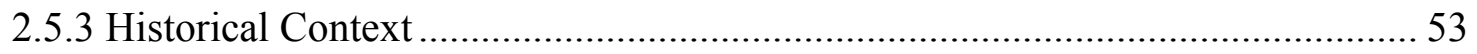

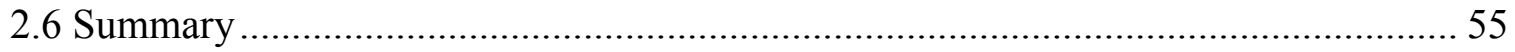

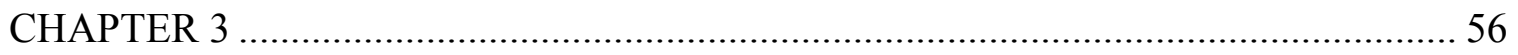

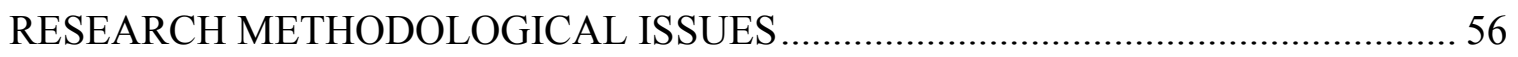

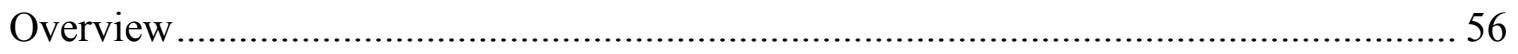

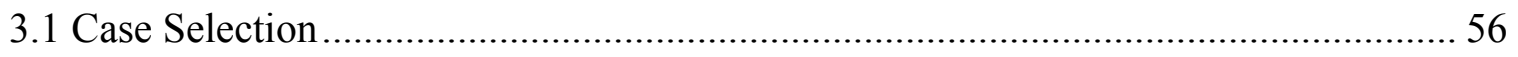

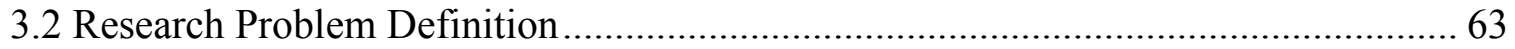

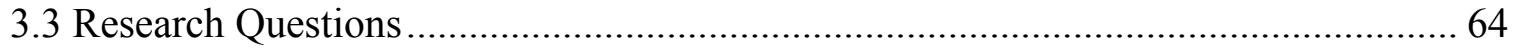

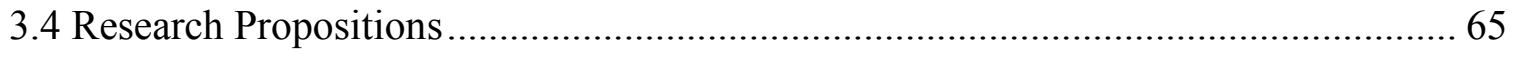

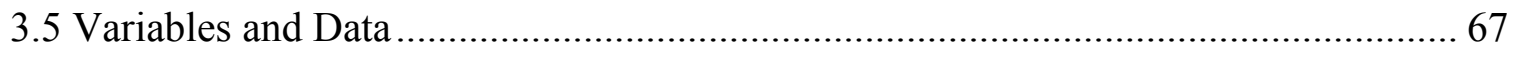

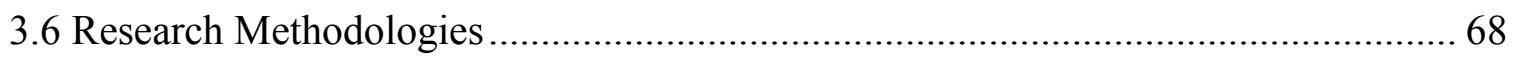

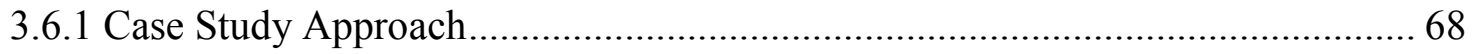

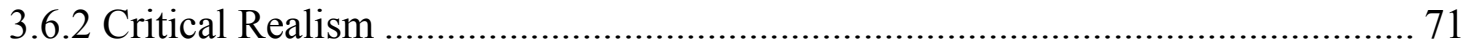

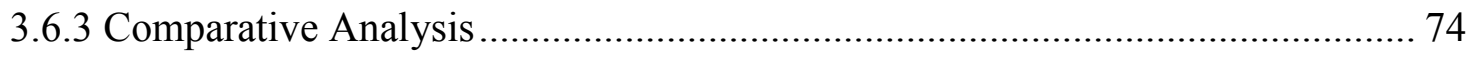

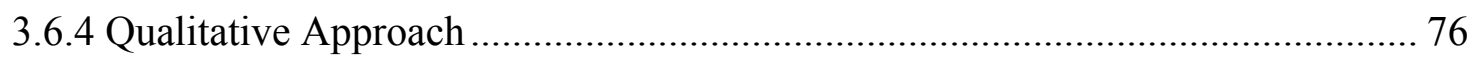

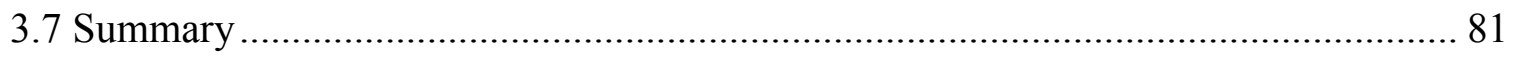




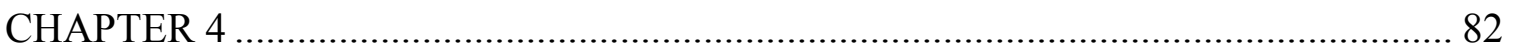

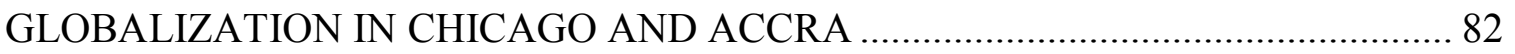

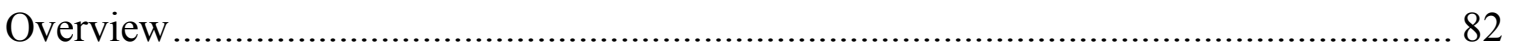

4.1 Comparing Globalization in Chicago and Accra .................................................... 82

4.2 Globalization in Chicago ………….................................................................... 91

4.2.1 Global Service Firms and Foreign Direct Investment ........................................ 93

4.2.2 Public-Private Partnerships and Civic Engagement ......................................... 102

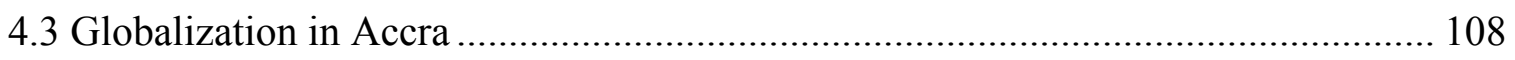

4.3.1 Global Service Firms and Foreign Direct Investment ..................................... 110

4.3.2 Institutional Restructuring and Public-Private Partnerships ............................ 122

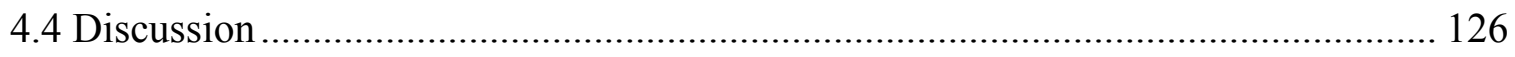

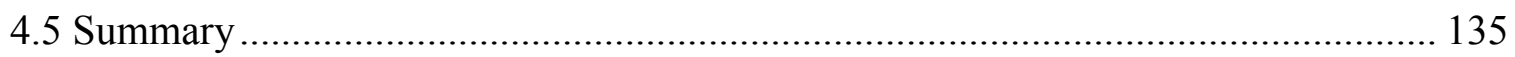

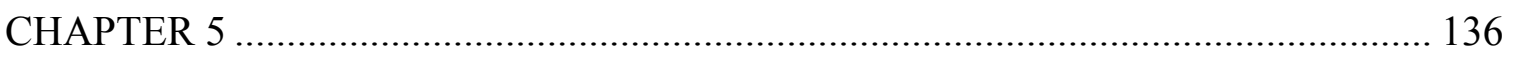

GLOBALIZATION AND REGIONAL COOPERATION: HOW LOCAL CONTEXTS

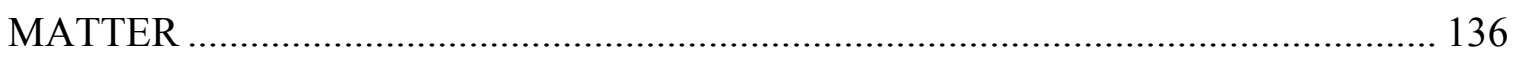

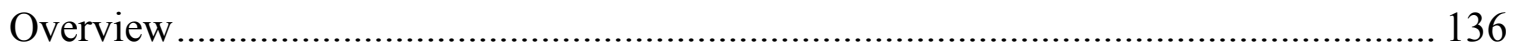

5.1 Comparing Regionalism in Chicago and Accra...................................................... 136

5.2 Regionalism in Chicago .................................................................................... 145

5.2.1 Complex Networks ................................................................................. 145

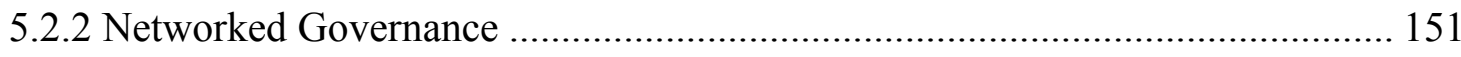

5.2.3 Flexible, Voluntary, and Informal Collaboration ............................................. 155

5.2.4 The Private Sector and Economic Logic ………................................................. 157

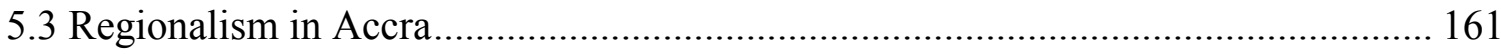

5.3.1 Hierarchical/Administrative Restructuring ..................................................... 162

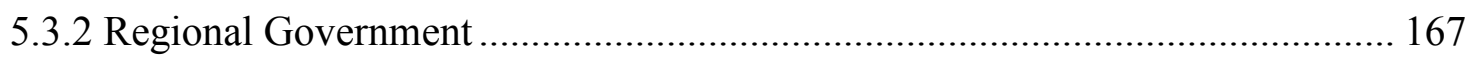

5.3.3 Administrative, Directed, and Formal Cooperation............................................ 167 
5.3.4 The Public Sector and Political Logic ........................................................... 172

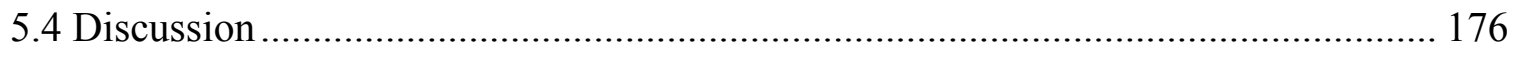

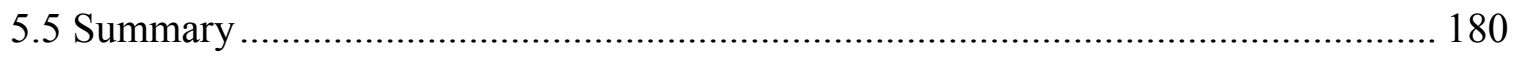

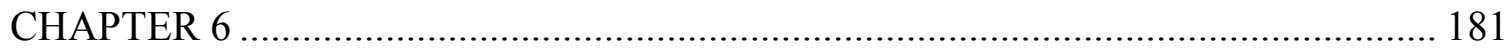

GLOBALIZATION AND RESCALING: THE ROLES OF LOCAL FACTORS ........ 181

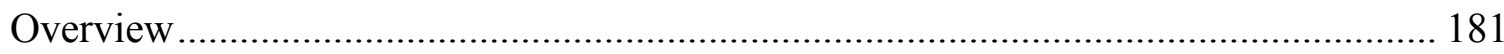

6.1 Comparing Rescaling in Chicago and Accra ......................................................... 181

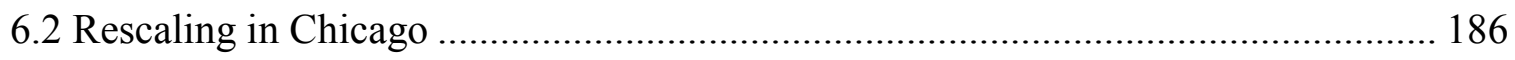

6.2.1 American Revolutionary Origins and Annexation .......................................... 187

6.2.2 Decentralization and Local Autonomy ………….......................................... 189

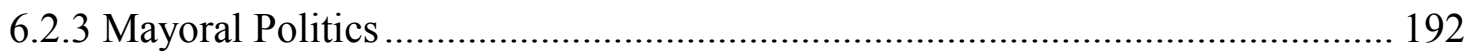

6.2.4 Political Fragmentation in the Global Era ................................................... 195

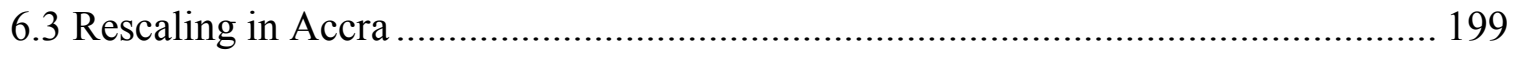

6.3.1 British Colonial/Postcolonial Origins and Territorial Expansion...................... 199

6.3.2 Centralization and the National Interest ......................................................... 203

6.3.3 Central Government Control........................................................................... 207

6.3.4 Bureaucracy in the Global Era.................................................................... 212

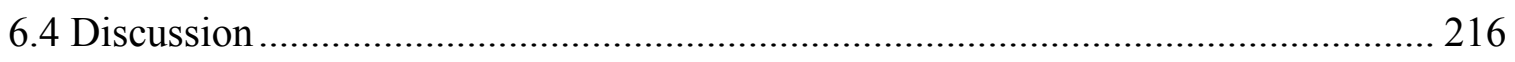

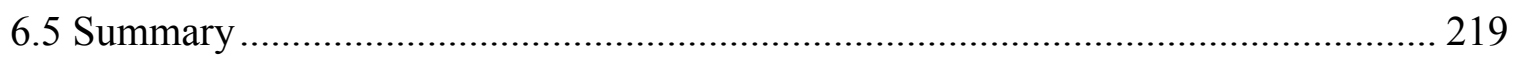

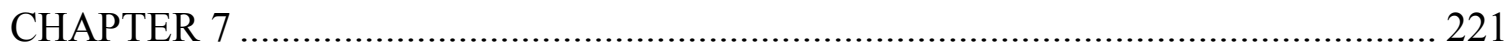

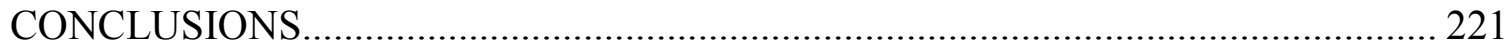

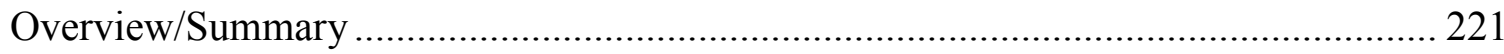

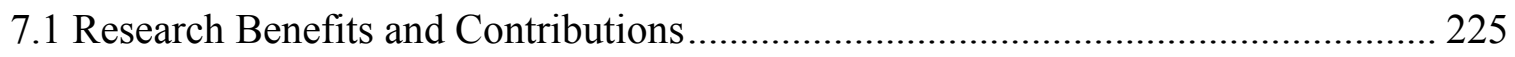

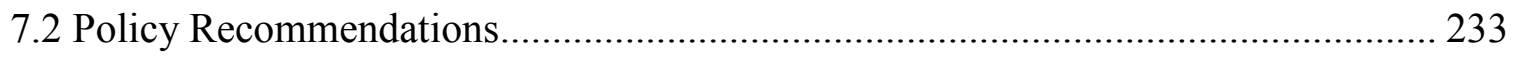


7.3 Future Research

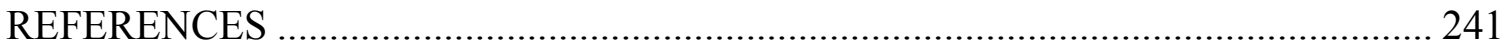

Appendix I: Interviews for the City-Region of Chicago, Illinois ............................... 274

Appendix II: Interviews for Accra, Ghana ….......................................................... 279

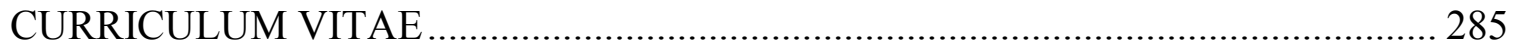




\section{LIST OF TABLES}

3.1 Demographics for Chicago and Accra......................................63

4.1 Globalization in Chicago and Accra.............................................83

4.2 Twenty Leading Global Cities................................................92

4.3 Some Fortune 500 Companies in Chicago, 2013 ............................94

4.4 Foreign Direct Investments in Eight Large American Cities, 2003-2012............98

4.5 Employment in Foreign-Owned Firms within America's Large Metropolitan Areas,

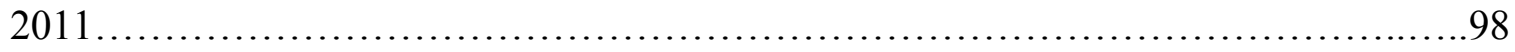

4.6 Sources of Greenfield Foreign Direct Investment in Chicago, 2003-2011...........100

4.7 Sectors for Chicago’s Greenfield Foreign Direct Investment, 2003-2011..........101

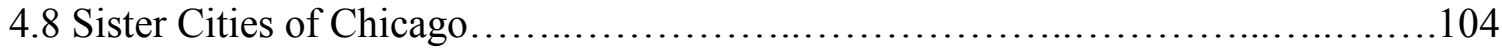

4.9 Rankings of Most Attractive Investment Destinations in Africa...................109

4.10 Regional Breakdown of Registered Projects and Investments: September, 1994 to

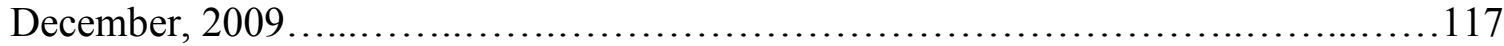

4.11 Registered Projects and Investments in Ghana: 1994-2009.....................118

4.12 Registered Investment Projects in Ghana by Country of Origin: September, 1994 to December, 2009.

4.13 Foreign Direct Investment in Ghana by Country of Origin: September, 1994 to December, 2009 (Approximate Values).................................... 121

5.1 Nature of Regionalism in Chicago and Accra................................ 137

5.2 Chicago Populations and Land Areas Per County............................... 147

5.3 Accra Populations and Land Areas Per Local Governmental Unit.................167

6.1 Rescaling in Chicago and Accra............................................182

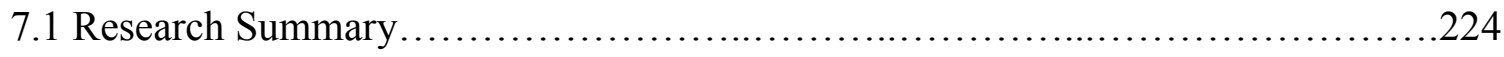




\section{LIST OF FIGURES}

1.1 Illinois Map Showing the Chicago Metropolitan Area..............................14

1.2 Ghana Map Showing the Greater Accra Metropolitan Area.........................15

5.1 Counties in the Chicago Metropolitan Area.....................................147

5.2 Some Local Governmental Units in Accra........................................164

5.3 Current Local Governmental Boundaries in the Greater Accra Metropolitan Area..166 


\section{CHAPTER 1 \\ INTRODUCTION}

\section{Overview}

Globalization may be defined as "the growing integration of the world, linking together into one global whole what had, heretofore, been independent activity centers all over the world" (Adams, 2011: p. 3). In the recent past, globalization has become a prominent force in the governance and development of localities. This occurred mostly from the 1970s onwards, as deindustrialization caused cities to resort to attracting capital investments from multinational corporations as a way of reviving their dwindling economic fortunes (Savitch and Kantor, 2002: pp. 4-13; Abrahamson, 2004: pp. 3\& 4). These multinational corporations usually operate simultaneously in different places; and this creates the need for localities to cooperate as a way of enhancing their competitiveness for business (Savitch and Kantor, 2002: p. 14; Vogel, 2010: pp. 4-5). Inter-local cooperation thus entails collective action among different localities in order to address common challenges which confront them, especially those which transcend political boundaries (Jung and Kim, 2009: p. 12; Koerner, 1968: p. 444). Collective action means working together to achieve certain desired goals and objectives. Inter-local cooperation is therefore a kind of collective action involving local governmental units in a city-region.

Two factors are especially paramount in understanding the forms of inter-local cooperation embarked on by specific localities. First, a city's need to assert its 
competiveness in global transactions and its level of integration into the global economy may entail the problems to be dealt with through collaboration either call for flexible/informal arrangements or require formal regional governmental structures. And second, the context-specific nature of a city may dictate its "paradigm" with respect to the pursuit of inter-local cooperation. By context-specific nature, I mean the unique economic, political, historical, and other factors which account for why things work the way they do in a particular place.

Based on the aforementioned observations, this study seeks to examine the differential implications of globalization for inter-local cooperation in two city-regions: one in the Global North (i.e. the developed world) and the other in the Global South (i.e. the developing world). Specifically, it focuses on Chicago, Illinois and Accra, Ghana. The research assesses how collective action is organized on a metropolitan aggregate scale, taking cognizance of the interactions between global and local factors. This is important because the prominence of globalization notwithstanding, the way collective action proceeds in different city-regions around the world depends on factors such as the benefits and associated expenses for individual localities. Moreover, the presence of a strong civic culture, and political or institutional frameworks, are crucial (Feiock et al., 2009: p. 267). In other words, different localities depending on their political cultures, path dependencies, and histories, decide what arrangements best work for them (Andersen and Pierre, 2010: p. $221 \&$ 223).

The main rationale for the study lies in the need to address a dearth in the existing literature: even though a plethora of research exists on the interface between global and local factors in urban development, there has been little scholarly attention on the global- 
local nexus with respect to inter-local cooperation in particular. This is a major shortcoming given that inter-jurisdictional collaboration has emerged as a major paradigm in city-regional development when it comes to addressing common challenges in the global era. Many studies such as Keum (2000), Kazowicz (1998), Feoick (2007), Andersen and Pierre (2010), and Jacobs (2004) focus on just the global or local factors associated with collaborative ventures among localities. The reality however is that both global and local factors interact to determine the nature of inter-local cooperation embarked on by many localities.

Inter-local cooperation entails the notion of rescaling. Rescaling means redefining the territorial, managerial, and political frameworks within which governance or government operates (Savitch and Vogel, 2004: pp. 760-763). Territorially, inter-local cooperation may result in a change in the spatial scale associated with governance or government. Managerially and politically, it may entail either downward rescaling (i.e. decentralization) or upward rescaling (i.e. centralization). Strong arguments have been made with respect to the implications of globalization for both downward and upward rescaling. For instance, it is argued that the phenomenon creates the need for the transfer of power from central governments to local governmental institutions i.e. decentralization. This helps localities to fashion out their own development strategies in order to enhance their competiveness in an increasingly globalized world (Tsukamoto and Vogel, 2007: pp. 17 \& 18). Another argument however emphasizes that globalization brings about the need for strong central government control in order to protect localities from the vagaries associated with the forces of global capitalism; and 
this connotes centralization of governance (Tsukamoto and Vogel, 2007: pp. 22, 28, \& 30; Brenner, 1999b: pp. $431 \& 447)$.

Notwithstanding the relatively strong arguments made concerning the implications of globalization for both decentralization and centralization, only a few studies such as Cox (2004) and Peck and Tickell (2002) have explicitly examined the roles of local contexts in mediating the ramifications of the phenomenon for rescaling. Moreover, works such as Brenner (1999b) which have looked at the global-local nexus in rescaling focus mostly on the Global North, to the virtual exclusion of the Global South. This is a major oversight since the spread of neoliberal ideologies to many societies in Africa, Latin America, and Asia means that these places are increasingly becoming integrated into the global economy. This study therefore addresses the dearth in existing research by exploring the differential ramifications of globalization for rescaling in both the Global North and South, taking cognizance of their unique local contexts.

\subsection{Globalization, Nations, and Cities}

According to Savitch (2002), the current wave of globalization, which mostly began in the 1970s, may be defined based on a number of distinguishing attributes. To begin with, the phenomenon is associated with rapid technological advancements, leading to improvements in the pace of economic activity. For instance, there was a fifty-four fold increase in the number of American stock and bond transactions recorded worldwide between the 1970s and early 2000s (Savitch, 2002: p. 181). Closely related to the improvements in technology has been the enhancement in information processing and 
exchange. For instance, the number of computers in the world jumped from around 50,000 in the middle part of the 1970s to 556 million in the early 2000s (Savitch, 2002: p. 181). Globalization also entails a rise in universally accepted products and services. For instance, currencies such as the euro and dollar have become benchmarks for trade in stock markets all over the world. Moreover, various fields of endeavor such as accounting and law have developed accreditations which have gained acceptability in much of the world (Savitch, 2002: p. 181). Also, the global era has witnessed an increase in interactions between nations, regions, and cities. Thus, there have arisen supranational, sub-national, and related bodies which seek to promote economic and political cooperation among various jurisdictions (Savitch, 2002: p. 181). Moreover, through increased exchanges, globalization has heightened the sense of interconnectedness amongst localities. This occurs because problems such as economic meltdowns in particular regions can engulf many others, compounding already existing situations (Savitch, 2002: p. 182).

Economically, globalization entails "a process of interaction and integration among the people, companies, and governments of different nations, a process driven by international trade and investment and aided by information technology" (Levin Institute of the State University of New York, 2014). As regards international trade, the phenomenon results in "specialization" and "exchange" (Boudreaux, 2008: pp. 3-4). That is, different nations or cities concentrate on the production of goods and services associated with competitive advantage and exchange them for those characterized by higher production costs (Boudreaux, 2008: p. 4). Globalization also entails increased foreign direct investment inflows. For instance, since the 1980s, the levels of such 
investments around the world have grown by more than 350\% (Boudreaux, 2008: p. 4). Moreover, there has been a tremendous growth in tourist traffic, with the volume of global tourist inflows expanding by 2400\% since the 1950s (Boudreaux, 2008: p. 6). Also, technological advancements, with respect to the Internet and telephone, for instance, have led to an increasingly inter-connected world. Through the platform of the Internet, information and news outlets from all over the world are available at the "click of a button." As regards telephone usage, between 1991 and 2004, the volume of international phone calls increased from below 40 billion to approximately 135 billion (Boudreaux, 2008: p. 6).

Politically, globalization entails increased interactions among societies around the world, even in disparate locations, which result in new conceptualizations and synergies for governance and development (Sassen, 2001: pp. xix-xx, 3-4). The term political globalization was defined by Beck (2000: p. 11) as "the processes through which sovereign national states are criss-crossed and undermined by transnational actors with varying prospects of power, orientation, identities and networks." Thus, the phenomenon challenges the political status quo and creates a platform for citizens around the world whose voices may have been subdued within the framework of the nation-state (Beck, 2000: pp. 1-2). Also, while globalization leads to criticisms of the nation-state and its welfare system, it results at the same time in a re-assertion of the relevance of this polity through "re-nationalization" (Beck, 2000: p. 3). Moreover, the proliferation of multinational corporations brings to the fore the need for greater coordination with respect to the activities of these firms. This leads to the emergence of new management and governance techniques with universal applicability (Sassen, 2001: pp. xix-xx, 3-4). 
Besides, the increased clout or influence available to multinationals make them more active players in the governance and development processes of nations and cities (Alperovitz, 2011: p. 15).

Given the desire to attract investments from multinational corporations, city and regional governments may go out of their way to institute several business-friendly measures such as tax concessions and subsidies (Alperovitz, 2011: p. 15). Multinational corporations outsource job opportunities to several places around the world and are thus able to negotiate the best terms from various governments for their operations (Beck, 2000: pp. 3-4). To cite an example, the amount of income taxes paid by these big firms in the United States decreased from about $35.4 \%$ of revenues in 1945 to $7.4 \%$ of proceeds in 2003 (Alperovitz, 2011: p. 15). It must be noted that in an attempt to attract foreign direct investment, localities begin to compete against each other given the leverage available to multinational corporations to relocate their operations (Douglass, 2002: pp. 55-59). At the same time however, increased regional connectivity heightens the global scope of challenges and brings people from all backgrounds together to fashion common solutions to them (Brenner, 1999: p. 431; Wells, 2001; p. 13). Specifically, it pools synergies among various localities in terms of the exchange of information, and integration of economic and political structures (Douglass, 2002: pp. 65-67). Thus, collaborative ventures among jurisdictions hold the key to generating common benefits for the various parties involved in urban development (Douglass, 2002: p. 66). 


\subsection{Inter-Local Cooperation, Governance, and Government}

The talk of globalization therefore brings to the fore the subject of inter-local cooperation. Inter-local cooperation entails collaborative ventures or collective action among several local governmental units with the object of addressing challenges which cut across jurisdictional boundaries (Jung and Kim, 2009: p. 12; Koerner, 1968: p. 444). A number of factors may account for the need to collaborate. To begin with, globalization creates the need for localities to enhance their economic competitiveness at the regional level in order to attract investments from multinational corporations (Albrechts et al., 2003: pp. 113-115). The global era also creates the imperative for efficiency in the provision of public services. As a result, several local governments have been pooling resources as a way of avoiding duplication of services and thus generating windfall gains (Peters and Pierre, 2001: p. 132). One major form of inter-local cooperation which has been embarked on in this regard is "metropolitan re-organization," which involves the annexing of adjacent territories by existing localities (Nivola, 1999: p. 63). This form of regionalism promotes economic efficiency by avoiding duplication in services provided by adjacent localities (Nivola, 1999: pp. 63-64). A third reason for inter-local cooperation is that some localities may not have the financial and economic wherewithal to deal with the problems which confront them. As a result, there arises the need to join forces with other local governmental units (Peters and Pierre, 2001: p. 132). Metropolitan reorganization for instance helps the economies of central cities and suburbs to thrive by creating a common and usually larger pool of tax revenues from which funds can be sought for development (Nivola, 1999: p. 63). 
Inter-local cooperation aims at creating stronger synergies for development (Andersen and Pierre, 2010: p. 221). Thus, localities taking cognizance of the costs and benefits of collective action embark on various forms of collaboration ranging along a continuum from flexible/informal arrangements to hierarchical/formal ones (Chen and Thurmaier, 2009: p. 536; Andersen and Pierre, 2010: pp. $221 \&$ 223; Koerner, 1968: p. 444). At one end of the scale, these collaborative arrangements may be in the form of simple agreements or contracts with respect to the solution of a particular problem. For instance, two communities may agree to collaborate in order to clear snow or manage refuse which can be found in both territories (Chen and Thurmaier, 2009: p. 537). At the other end of the spectrum, inter-local cooperation may involve formal agreements among complex structures or networks of governments with the objective of providing particular services such as fire protection and security (Chen and Thurmaier, 2009: pp. 537-538). Localities may prefer this arrangement because unlike public-private partnerships which may have an element of the profit motive, these collaborative arrangements serve the public interest (Chen and Thurmaier, 2009: p. 538).

The talk of inter-local cooperation brings matters of "governance" and "government" into the limelight. Governance refers to flexible and voluntary partnerships among parties who work together towards the attainment of certain desired goals and objectives (Savitch and Vogel, 2000: p. 161; Davies, 2007: p. 199). This arrangement generates mutual benefits through the fashioning out of agreements on issues considered to be of priority by the parties involved. Governance stresses horizontal relationships among partners and is therefore a fluid process. It is associated with the notions of decentralization and local autonomy (Savitch and Vogel, 2000: p. 161). In the United 
States, metropolitan areas such as Chicago place emphasis on governance due to the unwillingness of many local governmental units to cede their autonomies to wider regional forces.

The notion of "governance" differs from the more conventional term of "government." Government refers to the institutional and political frameworks responsible for the delivery of governance outcomes (Savitch and Vogel, 2000: p. 161). This mechanism is vertical in nature and is therefore associated with the creation of hierarchies and channels towards attaining certain goals and objectives. It stresses coordination, implying that cooperation is usually administrative and directed in nature. Thus, emphasis is placed on centralization and protecting an overarching interest (Savitch and Vogel, 2000: p. 161). In Ghana for instance, metropolitan areas such as Accra typify the notion of government due to the imperative to protect the overriding national interest in the development process.

\subsection{Globalization, Inter-Local cooperation, and the Roles of Local Factors}

Keum (2000: pp. 97-98) observes that collaborative ventures among localities is important because globalization has made cities more important players at the regional level. Specifically, the study asserts "open regionalism" is crucial for addressing development challenges in the global era (Keum, 2000: p. 114). It opines interjurisdictional problems, by their nature, call for collaborative solutions, sometimes even among cities across different national territories (Keum, 2000: pp. 113-114). For instance, the cities of Beijing, Seoul, and Tokyo in North-East Asia have been embarking 
on various collaborative ventures to address common challenges which confront them (Keum, 2000: p. 97). This occurs within the ambit of the Beijing Seoul Tokyo (BESETO) collaborative scheme which promotes cooperation with respect to trade, investment, and other facets of economic development (Keum, 2000: pp. 97-98).

Globalization results in the "reterritorialization" of the urban landscape (Brenner, 1999b: p. 431). This is because, the phenomenon implies the addressing of interjurisdictional challenges; and by default a rescaling of phenomena. The result is a wide range of scaling arrangements; both nested and inter-linked (Brenner, 1999b: p. 447). For instance, cities belong in both national and global territorial domains, thus creating complexities when it comes to analyzing spatial scales. The notion of urban rescaling associated with the global era leads to similar developments at the national level, a situation which in turn results in reconfigurations of the urban landscape (Brenner, 1999b: p. 447). Globalization is therefore associated with the emergence of both "supra-" and "sub-national" reconceptualizations with respect to the scaling of governance (Brenner, 1999a: p. 41). As a result, a host of platforms i.e. local, regional, national, and global, have emerged for addressing inter-jurisdictional challenges (Brenner, 1999a: pp. 50-51). The result has been the "transcendence of the state-centric configuration of capitalist territorial organization that prevailed throughout much of the twentieth century" (Brenner, 1999a: p. 41).

Notwithstanding the obvious implications of globalization for regionalism, the issue of local context still remains paramount. Peck and Tickell (2002) observed that neoliberal globalization is conditioned by local historical, political, and social factors. Similarly, Yeung (2002: p. 286) noted "the spatiality of globalization is an outcome of 
social constructions of space that are mediated through historically specific political, economic, and technological forces." In other words, context-specific factors such as the economics, politics, path-dependencies, and histories of particular jurisdictions influence the implications of globalization. With specific reference to regionalism, these local factors define the nature of the tensions and trade-offs associated with collaborative arrangements, as well as the priorities therein (Gibbs and Jonas, 2001: p. 274). In the U.S. state of California for instance, efforts towards regionalism are limited by Proposition 13, a legal instrument which places emphasis on the local generation of tax revenues. This law pits localities against each other in their efforts to attract investment and therefore promotes competition, rather than cooperation (Jonas and Pincetl, 2006: pp. 482, 501502).

The national framework within which regional arrangements emerge may also define whether there is a formal or informal approach to collaboration (Gibbs and Jonas, 2001: p. 274). In the American context for instance, the rise of "competitive regionalism," associated with the global era has led to an increased emphasis on voluntary collaboration among autonomous localities, rather formal regional governmental structures per se, as a way of addressing problems associated with the fragmentation of governance (Jonas and Ward, 2002: p. 391). And in the United Kingdom, the post-war years resulted in an increased emphasis on the region as the axis of transformation (Jonas and Ward, 2002: p. 389). Thus, the formation of Regional Development Agencies in the recent past has placed regional cooperation firmly within the realms of official government policy (Gibbs and Jonas, 2001: p. 269). Moreover, notwithstanding the decentralizing or centralizing implications of globalization for inter- 
local cooperation, the path dependencies or development trajectories of specific national domains determine whether or not there is a trend towards decentralization or centralization (Cox, 2004: p. 28). In the United States for instance, there has been a long history of political fragmentation; and in the United Kingdom and Ghana, centralization has long been the dominant political ethos (Cox, 2004: p. 28; Ayee, 1996: p. 133).

\subsection{Scope and Justification of the Study}

This research employs an exploratory case study approach to assess the differential experiences of two city-regions with respect to inter-local cooperation in the global era. Specifically, it focuses on the metropolitan areas of Chicago in the American state of Illinois and Accra in Ghana (Figures 1.1 and 1.2). Chicago and Accra were chosen because given their entirely different economic, political, path-dependent, and historical contexts, a compelling case can be made for their comparative analyses. Chicago lies in the Global North and has a long history of private sector-led development and decentralization. Accra however lies in the Global South and is associated with public sector-led development and centralization. Thus, the main thesis of this study is that the ramifications of globalization for inter-local cooperation would be entirely different given the context-specific natures of the two metropolitan areas.

The research seeks to accomplish three main objectives. First, it assesses the nature of globalization in Chicago and Accra, taking cognizance of their unique local contexts. The second objective of the inquiry is to explore the differential implications of

globalization for regional cooperation in the two metropolitan areas given their respective 
economies, political cultures, path dependencies, and histories. Specifically, it will evaluate whether the localities have a flexible/informal or an institutional/formal approach to collaboration. Third, this research explores the ramifications of globalization for rescaling in Chicago and Accra given their context-specific political cultures, pathdependencies, and histories. In other words, it examines areal expanse and whether or not the scale of decision-making in the two jurisdictions (within the global era) is decentralized or centralized in nature.

Figure 1.1 Illinois Map Showing the Chicago Metropolitan Area

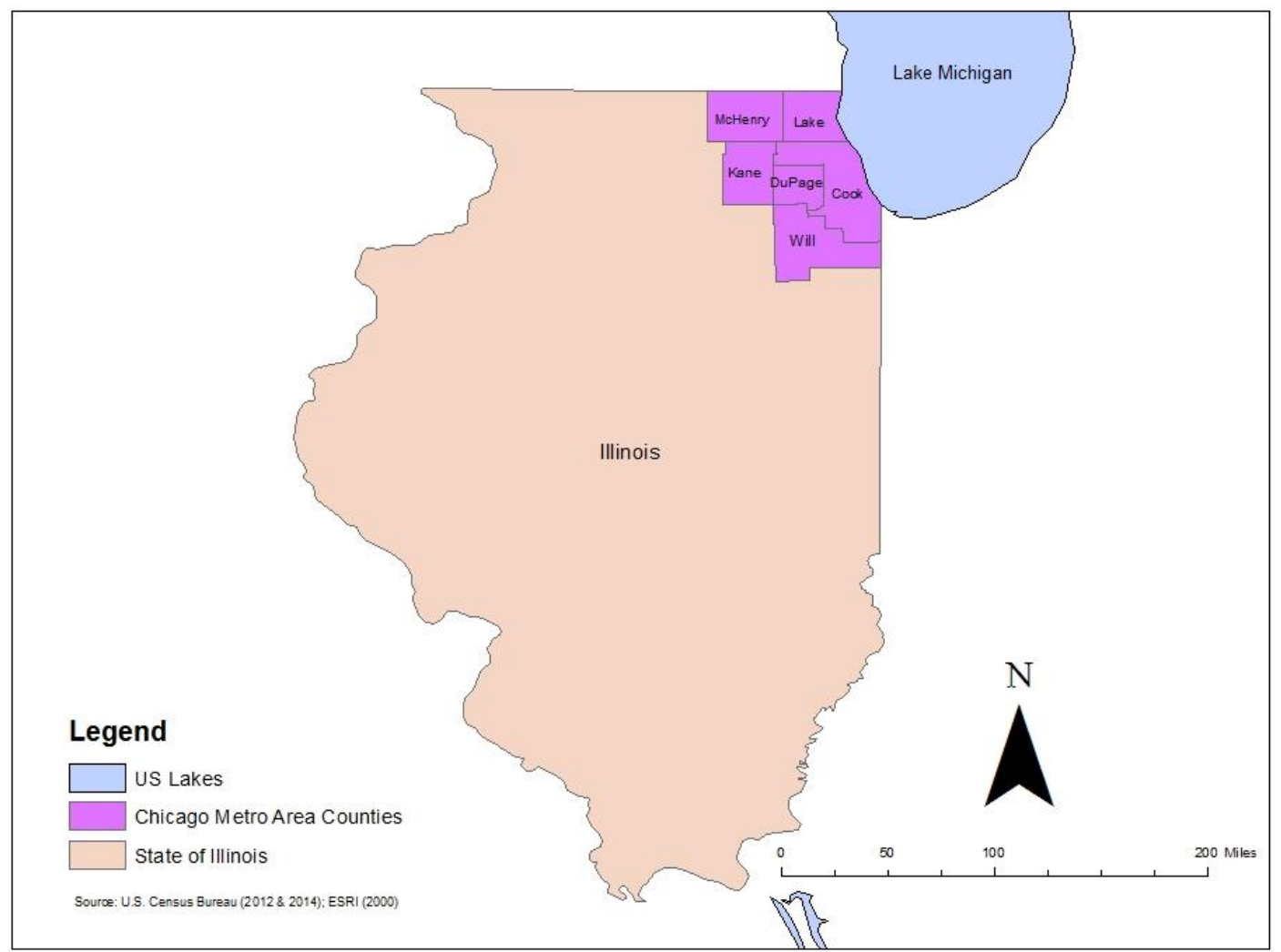


Figure 1.2 Ghana Map Showing the Greater Accra Metropolitan Area

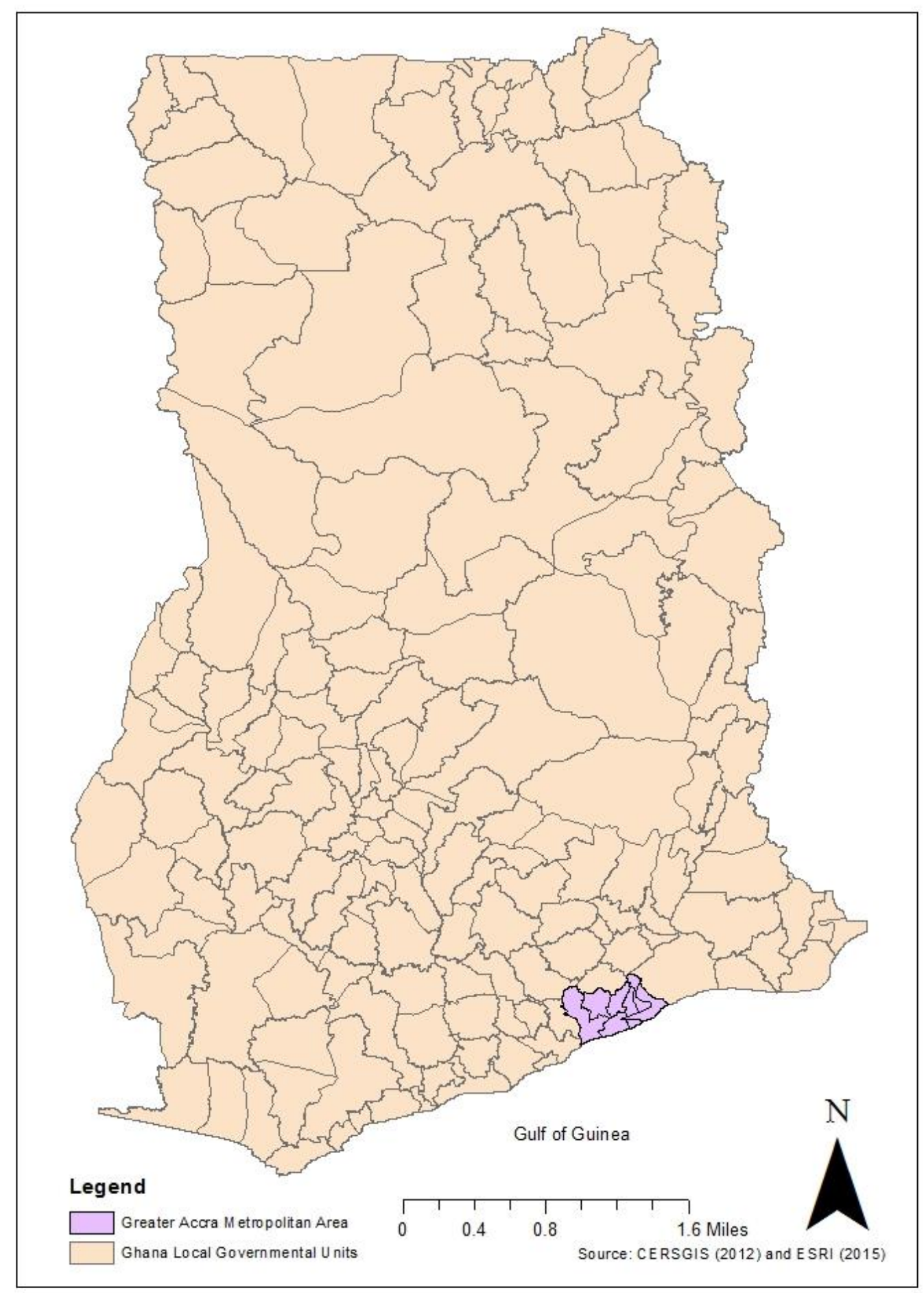


This research is justified because a relative dearth of inquiry exists when it comes to how the global-local nexus impacts inter-local cooperation in particular. As noted earlier, the development occurs notwithstanding the fact that many studies have examined the interactions between global and local forces in urban development. Undeniably, this is a major shortcoming because cooperation among localities has emerged as an important mechanism for addressing development challenges in the global era. Moreover, much of the research on inter-local cooperation has only focused on how local factors account for this phenomenon. A compelling case can therefore be made for an analysis of regionalism which takes cognizance of the roles played by both global and local factors.

Similarly, there is a relative paucity of inquiry on the differential implications of globalization for rescaling in various metropolitan areas. The existing literature implicitly attributes rescaling primarily to global forces. This study employs a comparative approach to argue that rescaling proceeds differently because local contexts vary. The investigation is also justified since existing research on the ramifications of globalization for inter-local cooperation focus on metropolitan areas within the Global North (and less so on those in the Global South). As noted earlier, given the growing integration of many parts of the Global South into the global economy, a strong argument can be made for a comparative analysis of regionalism as a way of pointing out important differences between the Global North and South. 


\subsection{Organization of the Study}

The study comprises seven chapters. Chapter 1 has introduced the basic ideas, objectives, and given a background to the inquiry. Chapter 2 provides a springboard for conducting the research through a literature review. Specifically, it discusses how the implications of economic and political globalization for regionalism are mediated by urban political economies, path-dependencies, and histories.

Chapter 3 explores methodological issues. It explains the logic undergirding the choice of the study areas. The chapter also specifies the research problem, questions, propositions, variables, and data. It discusses the rationale for the choice of methodological approaches such as case study, critical realism, comparative analysis, and qualitative method.

Chapter 4 assesses the nature of globalization in Chicago and Accra. It focuses on the presence of global firms, foreign direct investment, public-private partnerships, civic engagement, and institutional restructuring. In addition, the chapter analyzes the unique local factors in the two metropolitan areas which explain differences in the nature of globalization.

Chapter 5 examines the implications of globalization for the nature of regional cooperation in Chicago and Accra given their respective local contexts. The chapter focuses mostly on whether the two city-regions adopt flexible/informal or hierarchical/formal approaches to regionalism. 
Chapter 6 assesses the implications of globalization for rescaling, as mediated by local factors in Chicago and Accra. Specifically, rescaling will be analyzed in terms of areal expanse, decentralization, and centralization.

Chapter 7 will conclude this study. It summarizes the overall findings, discusses their importance, makes policy recommendations, and proposes areas for future research. 


\section{CHAPTER 2}

\section{LITERATURE REVIEW}

Overview

This chapter reviews relevant literature given the objectives of the research. Specifically, it discusses two main aspects of globalization (i.e. economic and political) and assesses the global city model. It also analyzes regionalism with respect to its nature and rescaling. Discussions subsequently look at the relationships between globalization and regionalism. It is observed that these relationships are context-specific; and this leads to an in-depth look at local factors affecting regionalism.

\subsection{Globalization and Cities}

As noted earlier, deindustrialization in the 1970 s caused many cities to resuscitate their economies through the attraction of capital investments from multinational corporations. Thus, cities today play major roles as hubs for global capitalist accumulation. To begin with, they serve as centers for the coordination of the flows associated with capital mobility (Sassen, 2001: p. 3). This occurs because they host the head offices or branches of multinational corporations. Also, cities in the global era serve as strategic locations for the operations of financial and other service industries (Sassen, 2001: p. 3). These urban areas have emerged as "sites of production," when it comes to 
technological innovations in the global era (Sassen, 2001: p. 3). In addition, cities provide a ready market for the goods and services produced by global firms (Sassen, 2001: pp. 3 $\& 4)$. Given the goals of the research, this section will throw more light on economic and political globalization, as well as the global city model.

\subsubsection{Economic Globalization}

Even though their foundations may have been laid decades earlier through increased international economic transactions, much of today's wave of globalization traces its roots to the period after World War II (Knox, 1997: p. 19). This period witnessed pronounced levels of investment in foreign markets by major firms, in a bid to increase their global economic base (Knox, 1997: pp. 18-19). From 1957 to 1967 for instance, about $20 \%$ and $30 \%$, respectively, of the investments in plants made by large American corporations in machinery and transportation logistics were in foreign markets. In the 1970 s, an economic slump was observed in many places around the world partly due to rising oil prices and deindustrialization. This created the need to look beyond traditional approaches to economic subsistence. Many cities therefore began to attract capital investments from multinational corporations as a way of regenerating their economies (Knox, 1997: p. 19). In the process, cities have emerged as focal points for the activities of global firms (Knox, 1997: pp. 22-23). For instance, as of the middle part of the 1990 s, about 40,000 of these firms could be identified around the globe, with cities in the United States, Europe, and Japan playing host to about $90 \%$ of their head offices (Knox, 1997: p. 19). Cities also serve as strategic locations for clusters of businesses and professionals seeking to carve niches for themselves in the global economy (Knox, 1997: 
pp. 22-23). The most defining features of globalization today are: the multinational character of economic transactions around the world and the increased emphasis on service sectors, such as finance and insurance, in these transactions (Knox, 1997: pp. 1821).

According to Yeung (2002: p. 287), economic globalization refers to "the rapid proliferation of cross-border production, trade, and investment activities spearheaded by global corporations and international financial institutions that facilitate the emergence of an increasingly integrated and inter-dependent global economy." Thus, it may be understood in terms of the unhindered mobility of skilled labor, capital, goods, and services across local or national borders (Allen and Thompson, 1997: pp. 213 \& 223). Specifically, this entails more pronounced levels of foreign direct investment, an increased role for global firms, and growing economic inter-linkages around the world (Allen and Thompson, 1997: pp. 213 \& 221). Economic globalization leads to a deemphasis of traditional borders, thus making it possible for multinational firms to spread their operations around the world (Allen and Thompson, 1997: pp. 213-214). These firms may enter into partnerships or networks with other corporations, thus increasing the geographic scope of their activities (Allen and Thompson, 1997: p. 219). Equally important is the investments made by these firms in research and innovation as a way of enhancing their levels of competitiveness, even beyond the traditional locales or nations where their operations tend to be concentrated (Allen and Thompson, 1997: p. 222).

Technological advancements are one major development associated with the global era. Florida (2002, pp. 6-7) observed that these advancements have led to the emergence of regional clusters, a situation which places emphasis on the locale as the 
lynchpin for attaining economic competitiveness. Florida's 2002 work noted the propensity for technological innovations to result in different spatial outcomes, implying that some localities thrived while others did not (Florida, 2002: pp. 6-7, 21-23, 243-245). This was partly due to the differences in the responses of various jurisdictions to the attraction of the "creative class" (Florida, 2002: pp. 6-7, 21-23, 243-245). Moreover, localities which nurtured the creative potential of their residents were more likely to prosper due to resultant technological and other innovations (Florida, 2002: pp. 6-7, 21$23,243-245)$. For a city to unleash the creative potential of its citizens towards economic development, it must abound in "technology," "talent," and "tolerance." Cities which possess all three elements thrive, while those which do not fail to do so (Florida, 2005a: p. 37). To cite an example, cities such as Baltimore and Pittsburgh, notwithstanding their technological endowments, have limited growth because they do not abound in adequate skilled labor and diversity (Florida, 2005a: p. 38).

In many places around the world, globalization has resulted in major changes with respect to the economic realm. To cite an example, the phenomenon has led to increased emphases being placed on prudent fiscal management and market reforms in the United Kingdom (Cochrane et al. 1996: p. 1320). Also, in many erstwhile socialist states, a redefinition of the roles of economics has resulted in new conceptualizations regarding urban development. Thus, there has been an increased resort to privatization and other economic liberalization measures, leading to a greater role for global capitalist forces within the urban economy (Wu, 2003: p. 58). Moreover, the degree of exposure of many developing societies to global capitalist forces may serve as the driving factor in their transformation to a market economic paradigm (Wu, 2003: p. 59). In the Indian city of 
Bangalore for instance, a decline in the quality of infrastructure and other facilities has led to some businesses re-directing their investments elsewhere (Madon and Sahay, 2001: p. 274). However, the city has sought to regain its competitive edge through the creation of "technology parks" (Madon and Sahay, 2001: p. 278). These parks demonstrate the rise of Bangalore as a global city because they are made up of global giants such as Sony and Motorola (Madon and Sahay, 2001: p. 282). Moreover, their focus on the promotion of exports and the emergence of Bangalore as a hub of international capital accumulation lend credence to their globalizing impacts (Madon and Sahay, 2001: pp. 278 \& 282).

\subsubsection{Political Globalization}

Politically, the notion of "embedded statism" asserts that the national context constitutes the defining yardstick for the organization of human activities in space. It is however important to note that just because an activity occurs within a nation's borders does not mean it is national in scope (Sassen, 2000: p. 145). Globalization has resulted in a reconceptualization of what constitutes internal and external matters within the framework of the nation-state. Thus, matters such as economic development and governance are no longer mere domestic considerations. Rather, they have gained the attention of leaders across the political divide i.e. both internally and externally (Held, 2000: p. 399). Globalization has thus led to a redefinition of the territorial frameworks for defining power relations. Instead of the nation-state being the default scale for determining these relationships, emphases have shifted to urban, regional, and global scales as well (Held, 2000: p. 399). 
Closely related to the aforementioned observations is the fact that globalization has resulted in a decline, at least somewhat, in the power or clout associated with the nation-state. Thus, while the nation-state remains an important framework for policy and decision-making processes, both "sub- and supra-national" considerations have gained importance in these regards (Held, 2000: p. 399; Brenner, 1999a: p. 41). The "reterritorialization paradigm" associated with globalization may therefore imply the decentralization of governance (Brenner, 1999b: pp. 431 \& 447; Tsukamoto and Vogel, 2007: pp. $17 \&$ 18). This occurs in part because the phenomenon creates the need for localities to address their own development challenges and assert their competiveness in order to remain relevant in an ever-changing world (Tsukamoto and Vogel, 2007: pp. 17 $\& 18)$. At the same time however, globalization may also result in greater state control or centralization. This is due to the need to help localities withstand the vagaries associated with the forces of global capitalism (Tsukamoto and Vogel, 2007: pp. 22, 28, \& 30; Brenner, 1999b: pp. $431 \& 447)$.

In the global era, major changes have emerged when it comes to the governing of cities. These changes occur due to shifts in the political and institutional paradigms for delivering governance outcomes. The overhauls are aimed at ensuring more efficient and effective service delivery (Röber and Schröter, 2007: p. 41). In the city of Paris for instance, an office of Mayor was created as part of the wave of reforms. Prior to these changes, the president of France directly nominated district mayors for the arrondissements based upon the recommendations of the interior minister. After the reforms however, these leaders were elected by the "conseils d'arrodissements" as part of the process of enriching grassroots democracy (Röber and Schröter, 2007: p. 41). In 
Berlin, the mid-1990s witnessed a downsizing of the public sector as a way of ensuring efficient service delivery. The latter part of the 1990s also saw devolution of power, reforms to institutions and the planning process, as well as redistricting of boundaries at the local level (Röber and Schröter, 2007: p. 42). In London, the Greater London Authority was created in the year 2000, resulting in the direct election of the mayor and assembly members. Also, "executive agencies," were established to perform administrative and planning functions (Röber and Schröter, 2007: p. 42).

Another major development associated with political globalization has been the rise of city-regions (Scott, 2001: p. 372). It may be argued that gradually, city-regions in the global era are beginning to assume the salient roles they played in ancient times when city-states were the order of the day. That is, metropolitan areas such as New York, London, and Paris are emerging as the operational centers for the streamlining of transactions across the globe (Kaplan, 1999; Abrahamson, 2004; p. 168). As may be implied from earlier statements, the reduction in the political clout of the nation-state has a major role to play in this (Scott, 2001: p. 372). Thus, regions have the option of being active agents which seek to adopt policies or create institutions meant to tap into the benefits associated with the sway of the forces of global capitalism. Failure to do so means that they become victims of the ebbs and flows associated with global capitalist accumulation (Scott, 2001: p. 372).

Beside the emergence of city-regions, globalization has been defined by the heightened level of inter-linkages among various political actors. These players engage in various collaborative endeavors which defy local or national territorial borders (Held and McGrew, 2003: p. 186). The result has been the emergence of a host of political and 
pressure groups across the globe which seek to champion various causes (Held and McGrew, 2003: pp. 186-188). The activities of these political actors have been enhanced by technological advances such as the Internet which make it possible for them to exchange ideas and pool synergies quickly. Thus, new platforms such as social networking sites have become important arenas for the articulation of divergent political views in many parts of the world (Held and McGrew, 2003: p. 187). These fora have created useful avenues for demanding accountability from holders of public office. It is therefore evident that the way governance is carried out has undergone a fundamental transformation (Held and McGrew, 2003: pp. 187-188, 192). For instance, technological advances have resulted in new developments such as e-governance which seek to enhance governance speed and efficiency (Held and McGrew, 2003: p. 187). Moreover, globalization brings in its wake the need for a more strategic mode of governance, with the object of cutting down on waste and improving upon the efficiency of service delivery (Held and McGrew, 2003: p. 194).

\subsubsection{Global City Model}

The talk of economic and political globalization underscores the importance of the city in global economics and politics. In her epoch-making works, Sassen (1991 \& 2001) coined the term "global city" to describe a locale which constitutes the focal point of economic and political activity in light of the sway of the forces of global capitalism. According to Sassen, a global city is associated with the spreading out of the activities of multinational corporations around the world (Sassen, 2001: p. xix). At the same time however, there arises the need to coordinate and integrate the operations of these firms 
(Sassen, 2001: p. xix-xx). As the city becomes a hub for the operation of the main offices of these global firms, outsourcing becomes an increasingly viable alternative (Sassen, 2001: p. xx). This occurs as a way of enhancing management and production efficiency. The outsourced firms are associated with "agglomeration economies" because they become part of an intricate network of exchanges, with respect to labor, capital, and information. At the same time, relocation of the main offices of these global firms becomes more feasible as a result of the increased pervasiveness of capitalist flows (Sassen, 2001; p. xx). The global city therefore emerges as part of a complex web of inter-city linkages which straddle national territorial domains (Sassen, 2001: p. xxi). The increased role for multinational corporations in the urban economy, coupled with the emphasis on skilled personnel in the service sector, heightens the problems of economic and spatial polarization. Moreover, there arises a large informal economy, which is unable to compete with the large firms, given their profit levels and the vagaries of mainstream global capitalism (Sassen, 2001: p. xxi).

Sassen's global city model treats the city as a "command and control center" and thus stresses the salience of structural determinants in its evolution as a hub of global economic and political processes (Smith and Doel, 2010: pp. 26, 28, 33, \& 36). Notwithstanding the epoch-making nature of Sassen's model, the analysis largely failed to take cognizance of the "multiplicities" associated with cities as sites of global capitalist accumulation (Smith and Doel, 2010: p. 33). In other words, cities in the global era merely constitute locations where economic and political activities by various players are manifested spatially. These players, including ordinary citizens and the middle class, may not necessarily be mainstream actors when it comes to the operations of global firms. 
However, their efforts in the form of investment choices, economic inputs, and other factors may shape the vagaries associated with the operation of the forces of global capitalism (Smith and Doel, 2010: p. 35). Thus, the city in the global era may be regarded, not as a coherent, structural unity, but rather an amalgam of the multiplicative forces of global capitalism (Smith and Doel, 2010: pp. 33, 35 \& 36).

Other critiques exist concerning the global city model. For instance, one school of thought takes issue with the model's assertion that a city of two extremes (i.e. one rich and the other poor) can be attributed to the phenomenon of globalization. In other words, while such a relationship may well exist, it has not been established conclusively (AbuLughod, 1995: pp. 183-184). Closely related to this assertion is the viewpoint that while levels of social and economic inequality may have increased in the global era, it is overly simplistic to characterize the global city as comprising the haves and have-nots (Fainstein and Harloe, 1992: pp. 7-9). Another argument stresses that the national framework not only influences the economic ramifications of global forces, but also defines the context within which these forces operate. For instance, the nation-state may very well determine a city's approach to attaining a competitive edge, as well as its level of social and economic polarization (White, 1998: p. 456). Similarly, the global city model largely fails to take cognizance of the context-specific realities of particular territorial domains which may account for differential outcomes. These local factors may include historical contexts, as well as the level of importance of a city in a nation's economic and political life (Fainstein and Harloe, 1992: pp. 18-19; Harloe and Fainstein, 1992: pp. 237-238; Burgel and Burgel, 1996: p. 301). 
In a nutshell, critiques of the global city model are based on its assumptions or components. For instance, the model is premised on the principles of "neo-classical economics" (White, 1998: p. 457). That is, it opines the world is made up of a host of rational economic actors who seek to maximize profits and minimize losses. In the real world however, this may not always be the case (White, 1998: p. 457). Besides, the global city model is based on an ideology of "reductionist Marxism" i.e. it argues the world comprises rich and powerful multinational corporations, the strength of whose activities defy national territorial frameworks (White, 1998: p. 457). Notwithstanding the power and influence of multinational corporations in the global era however, the nationstate remains a primary regulating force when it comes to the operations of these firms (White, 1998: p. 457). The global city model is also underpinned by the principles of "modernization theory" (White, 1998: p. 457). Thus, it assumes the world is converging and becoming more alike. The reality however is that the global era is characterized by enormous diversity and heterogeneity, as the city emerges as an attractive destination for immigrants from all walks of life (White, 1998: p. 459). The global city model also has an "Anglo-American" bias (White, 1998: p. 457). In other words, it makes a somewhat implicit assumption of the sway of market forces, similar to what prevailed in the eras of Margaret Thatcher and Ronald Reagan, sweeping across the globe (White, 1998: p. 457). However, in places such as Japan and France, there are long histories of either government intervention in the marketplace or government cooperating with private entities to attain desirable social goals (White, 1998: p. 458-459). 


\subsection{Regionalism}

Having looked at economic and political globalization, as well as the global city model, the research now examines the subject of inter-local cooperation. This is important because as noted earlier, globalization creates the need for localities to cooperate in order to address common challenges. Specifically, the study focuses on regionalism, which is arguably the most proactive form of inter-local cooperation in the global era. The notion of regionalism connotes collaborative endeavors by various actors in a metropolitan area, with the object of pooling synergies and attaining common objectives.

\subsubsection{Nature of Regionalism}

According to Miller (2002: p. 101), the main types of regional collaborative and governmental arrangements include: "coordinating regionalism," "administrative regionalism," "fiscal regionalism," and "structural regionalism." Coordinating regionalism seeks to ensure that the development plans of individual locales are in sync with the broader development strategy of an entire region (Miller, 2002: p. 101). To cite an example, the enactment of the Intermodal Surface Transportation Efficiency Act of 1991 helped to attune federal transportation policy in the United States with that of individual localities by stipulating the establishment of metropolitan planning organizations (Miller, 2002: p. 103). Unlike coordinating regionalism, two broad mechanisms can be identified when it comes to administrative regionalism. In the first type, municipal governments usually delegate their responsibilities to counties and 
special districts (Miller, 2002: pp. 101, 106-107). In the second type of administrative regionalism, various localities embark on collaborative ventures on a regular and active basis as a way of addressing inter-jurisdictional challenges (Miller, 2002: p. 101). Unlike administrative regionalism, fiscal regionalism encourages collaboration among localities with respect to development financing (Miller, 2002: p. 101). As a result, different localities either pool their funds or share in the spoils of resources available for the benefit of an entire region (Miller, 2002: pp. $101 \&$ 109). Three broad forms of fiscal regionalism can be identified: "cultural asset districts," "tax-base sharing," and "peaceful co-existence strategies" (Miller, 2002: pp. $101 \&$ 110). Unlike the other forms of regionalism, structural regionalism involves alterations in the borders of current local governmental units (Miller, 2002: p. 101). These changes may occur through "annexations," "city-county consolidations," and "mergers/consolidations" (Miller, 2002: p. 101).

Feiock (2009) identified six main governmental forms associated with regionalism. In the first kind, known as "regional authorities," individual local government units are usually merged to create one government for an entire region (Feiock, 2009: p. 361). The rationale here lies in the need to ensure proper coordination of governance by cutting down on fragmentation and inefficiency (Feiock, 2009: p. 361). A second form of regional governance known as "managed networks" comprises public and/or private players who create various forms of inter-local collaborative arrangements (Feiock, 2009: p. 362). These actors also inject resources towards the operation of the networks and steer their affairs to ensure that they achieve desired goals or objectives. The third kind of collective action involves "regional organizations" (Feiock, 2009: p. 
362). These bodies are normally created by federal or state laws and have responsibilities for the comprehensive planning of entire regions (Feiock, 2009: pp. 362-363). However, they do not have binding powers and localities under their ambit enjoy considerable autonomy. Examples include regional planning councils, metropolitan planning organizations, and network partnerships (Feiock, 2009: p. 363). A fourth kind of collective action is "contract networks" (Feiock, 2009: p. 364). Here, formal contracts among various autonomous local governments create legally-binding frameworks for collaboration. Moreover, inter-local bargaining associated with this means that a certain level of optimality which minimizes transaction costs can be attained (Feiock, 2009: p. 364). In the fifth kind of regional cooperation or "collaborative groups and councils," various local players embark on joint projects through informal agreements aimed at yielding collective benefits (Feiock, 2009: p. 365). Even though they normally occur within informal social settings, participants are obliged to abide by agreements reached (Feiock, 2009: p. 365). Finally, "policy networks" entail flexible collaborative ventures involving localities based on the principles of trust and mutual understanding (Feiock, 2009: p. 365). They usually emerge informally and may be costly to operationalize due to the need to build consensus among all parties involved (Feiock, 2009: pp. 365-366).

In the global era, "new regionalism" is the main school of thought defining interjurisdictional collaboration (Wheeler, 2002: p. 269). Scholars such as Calthorpe, Pastor, Rusk, and Downs were crucial in the birthing of this perspective in the 1990s (Wheeler, 2002: p. 269). A number of ideologies are associated with new regionalism. To begin with, it stresses a "place-oriented" approach to development (Wheeler, 2002: pp. 269270). This marked a return to the territorial or spatial context of regional planning which 
suffered a relapse, particularly during the eras of regional science and neo-Marxist regional economic geography, in the 1940s and 1960s, respectively (Wheeler, 2002: pp. 269-270). Moreover, new regionalism has an activist orientation and therefore makes practical recommendations for the physical transformation of the urban landscape. Thus, concepts such as "smart growth" and "urban design" have become prominent issues within the discourse on regionalism (Wheeler, 2002: pp. 270-273). New regionalism also focuses on addressing the problems of poor coordination and fragmentation associated with postmodernism. Thus, it is based on a more comprehensive mode of planning which encompasses various dimensions: economic, social, and environmental, among others. As a result, subjects such as efficiency and sustainability have assumed important status (Wheeler, 2002: pp. 270-271).

Savitch and Vogel (2000) identified five broad approaches to new regionalism. One mechanism, known as "public choice" promotes fragmentation of governmental structures by encouraging citizens to make residential choices based on the quality of service provided (Savitch and Vogel, 2000: p. 164). A second approach, referred to as “complex networks," involves collaborative arrangements among different and overlapping autonomous local governmental units (Savitch and Vogel, 2000: p. 164). This allows for greater levels of flexibility in addressing challenges confronting different jurisdictions (Savitch and Vogel, 2000: p. 164). A third mechanism, known as "linked functions," seeks to associate specific governmental units with the provision of particular services. These may include police and fire protection, as well as sharing of tax revenues (Savitch and Vogel, 2000: p. 163). Unlike the "linked functions" method, an approach known as "multitiered," is based on a formal legal mechanism which establishes different 
governmental units either in lieu of or in addition to existing arrangements. These structures are put in place with the object of dealing with problems appropriately on the bases of the scales at which they occur (Savitch and Vogel, 2000: p. 162). A final mechanism, referred to as "consolidationist," involves the coalescing or merging of several individual local government units into a single governmental authority. This aims at cutting down on the waste associated with service provision and helping declining central cities to benefit from the economic fortunes of thriving suburbs (Savitch and Vogel, 2000: p. 162).

Unlike Savitch and Vogel (2000) who identified five broad mechanisms for attaining regionalism, Norris (2001) observed that true regional governance cannot occur in the absence of formal governmental structures. The study, which focused on two urban agglomerations in England, noted that since the scrapping of metropolitan county councils, governance at the regional level had been non-existent (Norris, 2001: p. 532). It was found that while voluntary collaboration existed among some local governmental units, these were mostly limited to matters around which consensus existed. Besides, voluntary cooperation served to entrench the ethos of local autonomy and political fragmentation, pushing regional issues to the backburner (Norris, 2001: p. 545). The study concluded that if regional governance in the United Kingdom cannot occur without formal governmental structures, then the possibility of this happening in the United States was even more remote. This was because while Britain emphasized a top-down governmental mechanism, the United States was characterized by autonomous decisionmaking at the local level (Norris, 2001: pp. $532 \& 546$ ). 


\subsubsection{Rescaling and Regionalism}

Regionalism is a form of rescaling with multiple interactions. This is because it involves collaborative efforts among different actors. The concept of a scale refers to the political and related mechanisms through which various actors coordinate their efforts towards the attainment of desirable goals and objectives. The notion of rescaling entails a redefinition of the political and related frameworks associated with policy and decisionmaking processes (Swyngedow, 2004: p. 33). That is, players in the governance process have to form new alliances and agreements, a situation which results in a change in power relations. In other words, while the political and economic leverages of some actors may be enhanced, that of others may be curtailed (Swyngedouw, 2004: pp. 32-33; Uitermark, 2002: p. 747). To cite an example, the global era has led to an increased role for extra-national actors, a situation which has resulted in a decline, at least somewhat, in the economic and political clout associated with the nation-state (Uitermark, 2002: p. 747). On the one hand, rescaling may be conceived in terms of a network of actors who either collaborate or compete towards the attainment of certain goals and objectives. And on the other hand, it may involve institutional structures which determine the regulatory framework for the deliverance of outcomes associated with the governance process (Swyngedouw, 2004: p. 33). While the processes of rescaling may not be regarded as the preserve of specific territorial domains, the spatial terrain nonetheless constitutes a primary focal point within which rescaling occurs. These spatial domains are therefore subject to change with respect to their areal expanse, significance, and form/composition (Swyngedouw, 2004: p. 33). 
According to Savitch and Vogel (2004), rescaling may be described in three main ways. First, it entails a "re-alignment" of the borders of specific territorial domains. This occurs because of the coalescing of previously autonomous or separate jurisdictions into a single entity. The aim here is to ensure a better mechanism for the coordination of development and planning. Besides, there may be an economic imperative to broaden the base for revenue generation through increased taxation of industries (Savitch and Vogel, 2004: p. 761). Second, rescaling involves a redefinition of the managerial frameworks associated with governance in particular geographical areas. Specifically, it entails a reconceptualization of policy-making and implementation processes (Savitch and Vogel, 2004: pp. 761-762). The rationale for this lies in the need to cut down on waste and improve government efficiency (Savitch and Vogel, 2004: p. 762). Moreover, there may be an economic goal to minimize losses and maximize revenues as a way of appealing to voters during elections (Savitch and Vogel, 2004: pp. 761-762). Third, rescaling entails a redefinition of the political frameworks involved in the governance process. For instance, there could be a change in the regulations associated with resource disbursement, legislation, and the voting process. Moreover, the leverage available to elected officials may undergo a change, and this could affect the delivery of outcomes in the governance process (Savitch and Vogel, 2004: p. 762).

Rescaling may entail the decentralization or centralization of governance. The notion of decentralization connotes the transfer of power from a centralized authority to lower levels of government as a way of enhancing citizen participation and paying greater attention to local matters (Hamilton, 2004b: p. 664). On the other hand, centralization entails lodging power in the hands of a higher level entity, thus leading to 
top-down mechanisms in the decision-making process ( $\mathrm{Li}$ and $\mathrm{Wu}, 2012$ : p. 55;

Hamilton, 2004b: pp. 668 \& 671). The trend towards the decentralization or centralization of government differs among countries or jurisdictions. For instance, the United States has a long history of decentralized governance, while the former Soviet Union was widely associated with centralized governance (Hamilton, 2004b: p. 676; Golubchikov, 2004). A model comprising both decentralized and centralized approaches to governance can also be envisaged. In China for instance, the period since 1978 has witnessed the devolution of power from the central government to local and regional authorities. This has occurred partly in order to protect local interests, as part of efforts to attain competitiveness at the regional level ( $\mathrm{Li}$ and $\mathrm{Wu}, 2012$ : p. 55). At the same time however, the central government has redoubled its efforts to ensure that the national interest reigns supreme in matters of local governance. This entails reining in decisions at the local level which may not further overall national development goals ( $\mathrm{Li}$ and $\mathrm{Wu}$, 2012: p. 55).

The process of rescaling is a continuous one, which is characterized by multiple players with overlapping interests. These players include various public and private officials engaged in the body politic of localities (Nelles and Durand, 2014: p. 104 \& 120). The actors are constantly involved in fashioning and re-fashioning out deals which best serve their interests. Thus, rescaling is an evolving process; one which is based on the modus operandi defined by the parties involved and is constantly seeking to perfect itself (Nelles and Durand, 2014: pp. 119-120). Rescaling is also premised on the redefinition of the institutional and political orientations associated with urban governance. This is because, it stresses the need to pool synergies as a way of cutting 
down on waste and generating collective benefits (Nelles and Durand, 2014: p. 104 \& 120). The institutional and political re-orientation associated with the process help to define the framework within which a region charts a new way forward. As a result, regional networks have emerged today "as the new motors of competiveness in the globalized economy" (Nelles and Durand, 2014: pp. 119-120).

\subsection{Globalization and Regionalism}

A number of relationships can be observed between globalization and regionalism. To begin with, globalization increases inter-linkages among localities and creates the need for collaboration as a way of addressing challenges which straddle local borders. This occurs partly because the phenomenon makes it paramount for localities to enhance their competitive edge at the regional level (Savitch and Kantor, 2002: p. 14). At the sub-national level, globalization makes it evident that individual locales are vulnerable on their own and need to join forces with others (Savitch and Kantor, 2002: p. 14). The result has been the emergence of both informal and formal regional governmental arrangements (Chen and Thurmaier, 2009: p. 536; Andersen and Pierre, 2010: pp. $221 \&$ 223; Koerner, 1968: p. 444). At the supra-national level, globalization manifests itself in terms of organizations such as the European Union and the United Nations. These bodies serve as the platforms where collective action between different nations and territories are fashioned out in order to deal with regional or global challenges (Savitch and Kantor, 2002: p. 14). With respect to multinational corporations, globalization results in tactical collaborations and mergers. These help firms to increase 
the global scope of their operations, minimize costs, and hence improve production efficiency (Sassen, 2002: pp. 92-93).

Globalization also entails the downward and upward scalar mobility of capital as a way of maximizing benefits and minimizing losses (Yeung, 2002: pp. 291-292). In other words, various actors in different spatial domains seek to assert their leverages by deploying these capitalist forces to their advantage (Yeung, 2002: pp. 291-292). The scalar dimensions of globalization are thus manifested by the fact that local, regional, and national territorial domains are becoming increasingly connected through the diffusion of global capital across jurisdictional boundaries (Yeung, 2002: p. 291). Undeniably, globalization is a complex phenomenon because while it transcends local, regional, and national scales, it is in the same vein constrained by the nested and inter-linked arrangements associated with the operation of these scalar units (Yeung, 2002: pp. 291292). In the period before the global era, the technological advancements associated with industrialization helped to create the situation today where capital can easily move across local boundaries. Thus, while the industrial era was characterized by the operation of firms within specific territorial domains, it nevertheless helped to lay the foundation for today's ethos of free movement of capital (Yeung, 2002: p. 290).

Kazowicz (1998) observed that regionalism makes the economies of nations more competitive by pooling resources from several localities. This ultimately lays the groundwork for future bilateral and multilateral agreements among various economies at the global level. Moreover, globalization at the regional scale first emerges in the form of spatial polarization (Kazowicz, 1998). This occurs because the investments of multinational corporations tend to be concentrated in specific regional clusters or 
business districts (Abrahamson, 2004: pp. 7-8). Also, regionalism arises as a way of counteracting the undemocratic and self-perpetuating ethos associated with globalization, particularly when it comes to economic and political transactions among nations and societies (Kazowicz, 1998). Besides, the unwillingness of some localities to accept the notion of universality of culture associated with globalization brings about the need for alternative scales of addressing challenges; albeit at larger levels than the existing urban framework (Kazowicz, 1998). In addition to the aforementioned relationships, globalization and regionalism may also be regarded as concurrent processes operating in an ever-changing world where the need exists to address societal challenges at both large and small scales (Kazowicz, 1998).

The inter-relationships between globalization and inter-local cooperation appear undeniable. In recognition of this, Vogel (2010: pp. 4-5) noted the crucial role of regionalism in enhancing the economic competitiveness of global cities. For instance, localities recognizing the potential economic gains from globalization take necessary steps to collaborate as a way of ensuring economies of scale and enhancing the quality of service delivery (Vogel, 2010: p. 5). Moreover, the emergence of regional governance structures creates a more coordinated approach to policy formulation; and this goes a long way to promote competitiveness through the rolling out of business-friendly strategies and the attraction of investments from global firms (Vogel, 2010: p. 5). Also, regionalism results in a more strategic mode of governance in order to address the needs of a metropolitan area. For instance, London has vested its strategic planning in the hands of a regional body as a way of enhancing its competitiveness in the global era (Vogel, 2010: p. 5). 


\subsection{The Global-Local Nexus in Regionalism}

Notwithstanding the obvious implications of globalization for regionalism, the role of local factors cannot be discounted. Many studies have looked at the interactions between global and local forces in urban development. For instance, Abrahamson (2004: pp. 7-8) noted that due to the tendency of multinational corporations to concentrate their activities in financial and business districts, globalization heightens the problem of spatial polarization in cities. Beall (2002: p. 47-50) also observed that globalization contributes to worsening the problem of spatial inequality, even when this polarization is caused in the first place by context-specific factors. In another related study, Han et al. (2012: p. 288) observed the phenomenon (i.e. globalization) is associated with wage disparities in China. Specifically, the study noted that higher levels of wage inequality were evident in cities closer to the coast. These areas were highly incorporated into the global economy, as skilled labor in global cities were well-paid compared to the rest of the population (Han et al., 2012: pp. 289-290). Also, in many American cities, the end of the industrial era has witnessed a dramatic decline in industrial activities since many firms have either folded up their operations or moved elsewhere. The result has been a dislocation of the fundamental economic structures of these cities (Doussard et al., 2009: p. 184). Moreover, due to the migration of many businesses from central cities to suburbs in the global era, the problem of spatial polarization has been heightened in many of these cities (Doussard et al., 2009: pp. 183-184).

With specific reference to regionalism, context-specific factors such as the need for individual localities to generate revenues through taxation can result in competition, rather than cooperation in the global era. This was evident in a study by Wolfson and 
Frisken (2000) which examined the attitudes of two core and four suburban localities in the Greater Toronto Area within Canada towards regional cooperation. The study observed that both the traditional manufacturing sector and attraction of investments from global service firms were characterized by intense competition (Wolfson and Frisken, 2000: p. 378). Only the efforts to retain local businesses were devoid of intense lobbying, largely due to the relatively small contributions of these enterprises to the economies of the localities (Wolfson and Frisken, 2000: p. 379). Overall, it was evident that notwithstanding the imperative to attain regional competitiveness in the global era through cooperation, municipalities in the Greater Toronto Area would continue to jostle with each other for businesses and investments due to three main local factors. First, the devolution of financial and other responsibilities by the Province of Ontario to these localities meant that they had to adopt proactive ways to raise more revenues (Wolfson and Frisken, 2000: p. 382). Second, the rapid rate of suburbanization implied heightened competition as more localities were brought on board. And third, the increased jostling for investments in the service sector meant competition was extending far beyond the frontiers of the manufacturing industry (Wolfson and Frisken, 2000: p. 382).

According to Swyngedouw (2004), globalization may be perceived as a glocal phenomenon. This is because it involves two contrasting processes: a transfer of power to actors beneath the nation-state, resulting in an increased emphasis on urban and regional frameworks; and a simultaneous "upward scaling" thus giving extra-national forces a greater role (Swyngedouw, 2004: p. 25). In other words, the rescaling paradigm associated with globalization brings to the fore the issue of glocalization which causes cities to operate as hubs in the global economy (Brenner, 1999b: p. 447). Glocalization 
may also be defined as "global localization" i.e. the phenomenon whereby global practices and phenomena manifest themselves differently within specific territorial domains (Robertson, 1992: pp. 173-174; Giulianotti and Robertson, 2007: p. 134). That is, elements of local culture perturb the ramifications of globalization, resulting in the development of unique identities, even in a global era. Thus, the interaction between global and local elements becomes a primary factor accounting for the emergence of differential spatial outcomes (Robertson, 1994; Giulianotti and Robertson, 2007: p. 134). Proponents of glocalization argue that global forces should not be treated as a threat to local identity. This is because jurisdictions seek to make adjustments to their unique political and cultural usages so that they can tap into the benefits associated with the phenomenon. Thus, the locale constitutes an inherent aspect of the manifestation of globalization (Robertson, 1994; Giulianotti and Robertson, 2007: p. 134). The notion of glocalization connotes an element of "relativization." That is, different jurisdictions compare themselves to others and seek to assert their identity in an ever-changing world (Robertson, 1992: p. 29; Giulianotti and Robertson, 2007: pp. 134-135).

In contributing to the discourse on glocalization, Lee and Ducruet (2009) observed globalization had manifested itself differently within the port cities of Singapore and Hong Kong. This was due to varying policy and regional frameworks, which had mediated the impacts of global forces in the two city-regions. In Singapore for instance, the global-local nexus resulted in the emergence of this port city as an economic "hub" in the Asia-Pacific region (Lee and Ducruet, 2009: p. 176). An increase in the volume of container movement was observed here due to the reliability of firms within the port sector. In the case of Hong Kong, the interactions between global and local 
forces resulted in the evolution of this city as a regional "gateway" (Lee and Ducruet, 2009: p. 176). This was exhibited by its growing importance within Guandong Province in particular, and mainland China as a whole. The increased regional role was due to the transfer of operations to the outlying areas of this port city. Overall, the absence of spatial contiguity in the case of Singapore and the presence of this contiguity for Hong Kong meant that the resulting outcomes for the two port cities were different (Lee and Ducruet, 2009: p. 176).

\subsection{Local Factors Affecting Regionalism}

Undeniably, local contexts have a major role to play in influencing the implications of globalization for regionalism. This study observes that four local factors (namely economics, political cultures, path-dependencies and histories) are particularly important when it comes to mediating the ramifications of globalization for regionalism. Thus, discussions in these respects will take place under the following headings: urban political economy, path-dependency, and historical context.

\subsubsection{Urban Political Economy}

The local context of regionalism may be understood in terms of urban political economy. This school of thought (which emerged in the latter part of the 1970s to replace the then dominant paradigm of human ecology) stresses the interactions between economic and political forces and how these affect urban development. Economic factors are crucial because they define who holds the power and resources necessary for the 
pursuit of the development agenda (Abrahamson, 2004: p. 10). Peterson (1981) stressed the salience of economic forces and argued that they constituted the pivot for enhancing the competitive edge of cities. According to Peterson (1981: p. 20), development policies serve the interests of a city when they enhance its overall economic, political, and social leverage. Thus, such policies increase a city's competitiveness in comparison to others, by maximizing the benefits associated with its land, labor, and capital resources (Peterson, 1981: p. 29). Due to Peterson's emphasis on the overall economic interests of the locale, his analysis largely fails to take cognizance of the needs and concerns of diverse elements in society and the tensions which may arise in an attempt to address them (Stone, 1987: p. 8). Towards dealing with these, one must take cognizance of the political configurations and players involved in such arrangements (Stone, 1987: p. 17). Moreover, the processes involved in fashioning out development strategies help determine whose interests are best served by the policies which emerge (Stone, 1987: $\mathrm{p}$. 18).

With specific reference to regional cooperation, the "political culture" among localities in question is important (Visser, 2002: p. 47). The notion of political culture refers to the practices, both formal and informal, which constitute the rules of conduct among actors in a particular polity (Elkins and Simeon, 1979: pp. 127-128). It comprises a host of options from which various categories of people make choices which inform the actions they take. It therefore defines the frameworks within which matters of interest are thrashed out and decisions are ultimately made (Elkins and Simeon, 1979: p. 131). The importance of political culture with respect to regional cooperation is derived from the fact that it determines whether local officials are more likely to go it alone or team up 
with each other to accomplish common goals. Moreover, economic factors in a particular community interact with its political culture to determine the prevailing organizational culture (Visser, 2002: p. 47). This organizational culture in turn influences the attitudes among local governments towards collaborative ventures (Visser, 2002: pp. 47-48).

According to Feiock (2007), both economic and political factors are crucial in influencing collaborative arrangements among different localities. First, the transaction attributes associated with the provision of a good or service is paramount. Thus, where such transactions yield windfall gains and the performance involved in providing a particular good or service can easily be monitored, the incentive for institutional collaboration is high (Feiock, 2007: p. 53). Moreover, localities which are distressed economically are more likely to cooperate as a way of pooling synergies for development (Feiock, 2007: pp. 54-55). Also, the political context of a locality, with respect to existing legislation and development goals, inform the approach to institutional collaboration (Feiock, 2007: p. 55). The attributes associated with political institutions in particular jurisdictions also affect inter-local cooperation (Feiock, 2007: p. 55). For instance, in a situation where institutional structures across adjoining localities are similar, the propensity for collaboration is high (Feiock, 2007: p. 56). The nature of networks associated with collaboration is another important consideration (Feiock, 2007: p. 56). Thus, the level of information exchanged within the network, as well as degree of coordination involved, determine whether cooperation is more closely-knit or loose (Feiock, 2007: pp. 57-58).

Towards extending Feoick's model of “institutional collective action,” Andersen and Pierre (2010) observed that the kind of problem at hand determines whether or not 
collaboration is really necessarily. For instance, in situations such as police and fire protection which call for the efficient utilization of resources, it is important for localities to cooperate in order to avoid duplication in service delivery (Andersen and Pierre, 2010: pp. 225-226). However, where the need exists to mobilize resources and attract investment, cooperation may not be a viable option because localities have to compete with each other for businesses (Andersen and Pierre, 2010: pp. 225-226). Moreover, the players involved determine whether or not there is inter-local cooperation (Andersen and Pierre, 2010: p. 228). Even in situations where adjoining localities are dissimilar, the differential availability of resources can be a pull for collaboration if the localities in question realize this need (Andersen and Pierre, 2010: pp. 228-229). Moreover, interpersonal relationships among the political leaders involved in cooperation can go a long way in determining whether there is a conducive or unfavorable atmosphere with respect to joint ventures (Andersen and Pierre, 2010: p. 230).

Jung and Kim (2009) noted that city-regions composed of service provision units such as school and special districts were more likely to engage in collective action than those which did not have these units. This was because the presence of these districts created the need for joint ventures a way of pooling synergies towards efficient service delivery (Jung and Kim, 2009: p. 21). The study also observed that urban-based counties with clearly demarcated borders were more likely to collaborate than rural-based counties with poorly demarcated boundaries. Collective action in the urban-based counties was enhanced by the presence of skilled administrative personnel who facilitated these interactions (Jung and Kim, 2009: p. 21). Also, cities which were in poor financial or economic shape were more likely to cooperate as a way of yielding collective synergies. 
Cities which were thriving financially however had little incentive to collaborate as they could easily afford the cost of service provision (Jung and Kim, 2009: p. 21). Ironically however, it was observed that counties in good economic positions had the tendency to cooperate in order to enhance the quality of service delivery. The study also noted that counties in the South, West, and East of the United States had a greater propensity of engaging in collective action than those in the Midwest (Jung and Kim, 2009: p. 22).

\subsubsection{Path Dependency}

Besides urban political economy, the issue of path-dependency is also important. The notion of path dependency connotes the tendency for a particular process to become steeped along a specific trajectory based on previous and current occurrences (Sydow et al., 2010: pp. 174-175). This may happen because institutional structures which develop over time tend to guide the progression of development along specific paths with the object of ensuring that replication takes place (Sydow et al., 2010: p. 177). While the concept of path dependency is usually associated with structural determinants of the development process, the import of human agency cannot be discounted (Sydow et al., 2010: pp. 189-190). That is, various players through their roles in the planning and public policy formulation processes help to deliberately steer the course of development in a particular direction. As a result, future outcomes are no longer the results of default structural factors, but rather carefully planned and executed mechanisms by relevant actors (Sydow et al., 2010: p. 190). Specifically, by working together to achieve common goals and objectives, the various actors in a region are able to ensure that the development process keeps replicating itself. These players may be able to bring about 
some level of innovation. However, historical antecedents usually steeped in structural factors mean that there are limits when it comes to the extent to which deviation from specific development trajectories can occur (Sydow et al., 2010: p. 190). Thus, structural and agency factors work hand-in-hand to guide the direction in which the development process proceeds (Sydow et al., 2010: p. 190-191).

In many instances, the resort to path-dependent behavior may be informed by the fact that similar actions in the past have yielded enviable results (Meyer-Stamer, 1998: pp. $1495 \& 1508)$. This notwithstanding, a change may occur when new circumstances create a compelling need for alternative approaches. In Brazil's Santa Catarina state for instance, companies within the region's business clusters refused to pool synergies when the market was not open to the outside world in the 1980s (Meyer-Stamer, 1998: p. 1495). After all, their self-reliance over the years had generated increased profit and output levels. Thus, even when the region's market was exposed to external competition from the early 1990s onwards, many of these firms initially refused to embrace a new ethos of collaboration as a way of enhancing their competitive edge (Meyer-Stamer, 1998: p. 1495). Over the course of time however, the emergence of various problems which threatened the continuous operation of these firms led to an embracing of the ideals of cooperation (Meyer-Stamer, 1998: pp. 1495, 1508, \& 1509). This development was further facilitated by the presence of players eager for change, as well as new institutional frameworks premised on innovation (Meyer-Stamer, 1998: pp. 1495, 1508, \& 1509). The business community's new posture towards change was however perturbed by the state and municipal governments which continued to pursue path-dependent 
policies as a result of their relatively inflexible political and administrative set-ups (Meyer-Stamer, 1998: p. 1495).

It must also be noted that within different national territorial frameworks, factors such as the nature of the decision-making process, race and social status, as well as policies by local firms may influence the respective approaches to cooperation among localities. In the city of Detroit in the United States for instance, local governments have greater autonomy in the governance process (Jacobs, 2004: p. 489). Unlike Detroit however, the centralized nature of decision-making in Japan requires localities in Tokai to collaborate as a way of whipping their development strategies in line with overall regional and national goals (Jacobs, 2004: pp. 490-491). As regards issues of race and social status, Detroit's political leadership, as well as Michigan state laws between 1969 and 1996, actively promoted segregation and discouraged inter-local cooperation by enabling citizens to protect the character of their neighborhoods (Jacobs, 2004: p. 493). In the city of Tokai however, the relatively low population of minorities, coupled with the absence of laws which curtailed their residential and migration choices meant that interlocal cooperation was not adversely affected (Jacobs, 2004: pp. 493-494). Beside issues of race and social status, the different strategies adopted by local auto producers in Detroit and Tokai generated varying outcomes as regards inter-local cooperation. In the case of Detroit, these auto companies promoted competition, rather than cooperation among localities by moving their operations to those areas which provided them with more incentives such as tax abatements (Jacobs, 2004: pp. 494-495). Unlike Detroit, the Toyota Motor Corporation in Tokai worked hand-in-hand with various communities as a 
way of helping them carve a niche for themselves within its scope of operations (Jacobs, 2004: p. 496).

According to Martin and Sunley (2006: p. 399), "a path dependent process or system is one whose outcome evolves as a consequence of the process's or system's own history." In other words, the way things have turned out in the past shape current and future results by causing the development process to proceed in a particular fashion. This may occur due to long-standing technological, institutional, and economic practices which make it difficult to define new frameworks for getting things done (Martin and Sunley, 2006: p. 399). Technologically, the reduced costs associated with the adoption of a particular approach, as well as the challenges involved in switching to alternative methods may cause the development process to become bogged down in a particular approach (David, 1985: pp. 334-335; Martin and Sunley, 2006: p. 399). Institutionally, customs and usages adopted over time may be difficult to change because of attachments to the past and entrenched interests (Setterfield, 1993: p. 760). Economically, the potential for "increasing returns to scale" may also lead to reluctance to change (Martin and Sunley, 2006: p.p. 401-402; Arthur et al., 1987). These returns to scale may occur due to cost savings observed after initial capital investments, the tendency to perfect costminimization and other efficient techniques over time, the pooling of synergies with similar entities, and the potential for an already existing system to replicate itself (Martin and Sunley, 2006: p.p. 401-402; Arthur et al., 1989, p. 116). Perhaps, the most defining attribute of path dependency is that its emergence and reinforcement normally depends on the place or locale within which it occurs. That is, it is context-specific and either 
defines or is defined by the realities within a particular locality in question (Martin and Sunley, 2006: p. 409).

The potential for "increasing returns to scale" has been articulated by many other scholars such as Pierson (2000a and 2000b) as a primary reason for path dependency in the development process. That is, various actors motivated by the prospect for gains continue to blaze particular paths as a way of maximizing benefits and minimizing losses. These scholars believe that the chain of path dependency is broken only when monumental external factors act upon the course of development (Gains et al., 2005: p. 28). Notwithstanding the importance of increasing returns to scale, its salience as a contributory factor to the trajectory of development may have been hyped. To begin with, the development process may be characterized as much by "decreasing returns to scale" as it is by "increasing returns." This makes the prospect of deviating from a particular path more likely than certain scholars may suggest (Gains et al., 2005: p. 28). Moreover, even though politicians may be keen on sticking to existing development frameworks in order not to upset the status quo, they may in the same vein be eager to shift gears as a way of endearing themselves to an electorate who may be yearning for change (Gains et al., 2005: pp. 28-29). Besides, contrary to popular perceptions, the potential for change in institutions exist through innovation and strategic thinking which define new paradigms for getting things done (Gains et al., 2005: p. 29). 


\subsubsection{Historical Context}

In addition to path dependency, the issue of historical context is paramount. Historically, colonialism was instrumental in shaping the emergence of the urban landscape. Specifically, the phenomenon helped to define the economic, political, cultural, and administrative configurations associated with urban development (King, 1992: p. 367). In former British colonies for instance, many societies were supply centers for raw materials and became heavily reliant on goods and services produced by big corporations in the West (King, 1992.: p. 367). The result was the spatial evolution of cities as hubs of economic concentration comprising financial institutions and transnational firms (King, 1992: pp. 367-369). Politically, cities in many parts of Africa and Asia also became centers of governance and administration due to the concentration of government buildings, police and military installations, roads, and other infrastructural facilities (King, 1992: p. 368). In the era of “industrial colonialism," authorities placed emphasis on the development of major cities based on their strategic locations as a way of facilitating trade, particularly with nations in Europe (Drakakis-Smith, 2000: p. 42). As a result, primate cities emerged as the dominant locales in the economic and political lives of these colonies (Drakakis-Smith, 2000: p. 42). By the 1970s, there was an increase in the costs of capital and labor inputs in the production process, a situation which led to many corporations in the West transferring at least part of their operations to locations in the developing world (Drakakis-Smith, 2000: p. 53).

With specific reference to the historical context of regionalism, the latter part of the twentieth century was marked by a phenomenal increase in the spatial expanses and population sizes of many metropolitan areas around the world. Besides, there was a 
tremendous rise in the rate of suburbanization, thereby worsening already existing levels of spatial inequality (Savitch and Vogel, 2000: p. 158). For instance, while 2.7 million residents in the United States moved from inner-cities to the suburbs in 1996, the figure for the reverse migration was 800,000 (Katz and Bradley, 1999; Savitch and Vogel, 2000: p. 158). This occurred because wealthy residents who could afford to do so usually migrated to the suburbs, thereby leaving the poor trapped in declining inner-cities (Savitch and Vogel, 2000: p. 160). The result was an increased level of sprawl. Thus, there has been a transformation both in terms of the mechanisms for physical planning and the political imperative (Savitch and Vogel, 2000: p. 160). For instance, many municipalities have adopted strategies such as zoning and growth management to address the negative effects associated with sprawl. Besides, there has arisen an increasing need for a regional approach to dealing with challenges confronting jurisdictions, especially those which cut across local boundaries (Savitch and Vogel, 2000: p. 160).

Within the American context, regionalism has historically proceeded without formal governmental structures per se. As a matter of fact, the past century or so has witnessed a lesser involvement by federal and state authorities in this respect, with laws being enacted towards this end. This runs contrary to the prevailing situation in places such as Canada where provincial authorities have increasingly assumed proactive roles in coordinating regional efforts (Frisken and Norris, 2001: p. 467). Efforts towards consolidation have traditionally been opposed by actors who cherish their local autonomy and fear the economic implications of regional efforts on their jurisdictions (Frisken and Norris, 2001: pp. 469-470). Thus, proponents of new regionalism argue that an allencompassing mode of planning and regional governance will help to address the 
challenges associated with the prevailing order. This new school of thought stresses that localities should engage in collaborative endeavors out of their own free will based on their evaluations of possible costs and benefits (Frisken and Norris, 2001: p. 468). Unlike the bureaucratic nature associated with previous regional efforts, new regionalism's concept of "governance conveys the notion that existing institutions can be harnessed in new ways, that cooperation can be carried out on a fluid and voluntary basis among localities and that people can best regulate themselves through horizontally linked arrangements" (Savitch and Vogel, 2000: p. 161).

\subsection{Summary}

This chapter has reviewed relevant literature in order to "frame" the research conceptually. It examined two main strands of globalization (i.e. economic and political), as well as the global city model. The chapter also looked at regionalism with respect to its nature and rescaling. It then discussed the relationships between globalization and regionalism, before noting that local contexts mediate these interactions. Thus, the chapter assessed the global-local nexus of regional cooperation; and looked in detail at local factors which account for regionalism (i.e. urban political economies, path dependencies, and histories). The next chapter explores research methodological issues. 


\section{CHAPTER 3}

\section{RESEARCH METHODOLOGICAL ISSUES}

Overview

In this chapter, I explore the research methodology and sources of investigation. The chapter first looks at the rationale for the selection of the two city-regions of interest. The research problem, questions, propositions (or hypotheses), variables, and data which constitute the focus of the study are then discussed. In addition, the chapter elaborates on the various methodologies (such as case study approach, critical realism, comparative analysis, and qualitative approach) employed.

\subsection{Case Selection}

As explained earlier, my approach to this research is exploratory. In this respect, much of the work done is idiographic in nature, entailing a good deal of historic and descriptive narration in order to conduct an in-depth analysis. The research is based on a city-region in the Global North (i.e. Chicago, Illinois) and another in the Global South (i.e. Accra, Ghana). Both Chicago and Accra are major urban areas in their respective national and regional territorial contexts. Chicago is the largest metropolitan area in the United States Midwest. It is America's third most populous and globalized urban agglomeration. Accra is Ghana's primate city and its largest metropolis. It is also the most globalized metropolitan area in the nation. There are a number of reasons for the 
choice of Chicago and Accra. To begin with, the two city-regions have been affected differently by the phenomenon of globalization. As a result, a compelling case can be made for a comparative analysis. With specific reference to Chicago, as many metropolitan areas in the United States underwent deindustrialization, the city's economy witnessed a marked decline in employment, income, and output levels (Savitch and Kantor, 2002: pp. 4-13; Sassen, 2004: pp. 19 \& 27). For instance, about $46 \%$ of the people employed in the manufacturing sector lost their jobs between 1967 and 1982 (Sassen, 2004: p. 19). Also, between 1991 and 1992, there was a decline in service employment by 31,000. In the latter part of the 1990s however, Chicago began to bounce back due to the inflow of several multinational corporations (Abrahamson, 2004: pp. 3 \& 4; Sassen, 2004: p. 19). As a result, employment levels by leading service firms, for instance, increased from below 17,000 in 1986 to approximately 60,000 in 1998 (Sassen, 2004: p. 21). Moreover, the metropolitan area has witnessed public-private partnerships and an increased civic engagement.

Unlike Chicago, the phenomenon of globalization assumed a prominent role in Accra when the Government of Ghana embarked on neo-liberal economic policies from the 1980s onwards through the influence of the International Monetary Fund and the World Bank (Grant, 2009: p. 8). The goal was to stem the tide of economic decline which had bedeviled Ghana in the 1970s and 1980s. As a result of these neoliberal policies, there was a phenomenal increase in foreign direct investment via top-down mechanisms, mostly by multinational corporations (Grant, 2009: pp. 9-10). In addition, institutional restructuring sought to reduce the over-centralization of governance; a legacy from Ghana's colonial vestige of public sector-led development. 
Another reason for the choice of Chicago and Accra is that the two city-regions have different arrangements with respect to inter-local cooperation; and these make for an interesting comparative case study. In the case of Chicago, regionalism mirrors what Savitch and Vogel (2000) referred to as "complex networks." That is, various independent local governmental units collaborate on matters which are of common concern to them. These arrangements are flexible and in many cases not legally binding (Orum, 2005). The forms of inter-local cooperation prevalent in Chicago may be explained by the fact that individual localities protective of their autonomies have been unwilling to consolidate into unified governmental units. As a result, the Chicago metropolitan area has witnessed a plethora of different and overlapping governmental units over the years (Orum, 2005).

Unlike Chicago, regionalism in Accra typifies what Savitch and Vogel (2000) referred to as the "multitiered" approach." This arrangement places emphasis on the creation of hierarchies as a way of ensuring a more coordinated approach to the development process. Thus, cooperation is usually of an administrative and directed nature. Moreover, the creation of hierarchies allows problems to be dealt with at different spatial scales. For instance, local matters are dealt with by bodies legally established at this level for these purposes (i.e. metropolitan, municipal, or district assemblies), while regional problems are addressed by a superintendent regional body (i.e. the Greater Accra Regional Coordinating Council).

A third rationale for the choice of Chicago and Accra is that the two city-regions have entirely different context-specific economies, political cultures, path-dependencies, and histories; and these also make for a strong comparative case study. As regards 
Chicago for instance, the metropolitan area's strategic location in the Global North, coupled with its level of integration in the global economy, places it at the core of global economic activity. For instance, the presence of two major rivers i.e. Chicago and Calumet, as well as the closeness of its location to Lake Michigan, has helped Chicago to emerge as a hub of water transportation (City of Chicago, 2010-2013). Moreover, the city-region is a railway hub, and comprises the O'Hare and Midway International airports (City of Chicago, 2010-2013). With respect to politics and path-dependence, Chicago lies in the United States, which is arguably the heart of capitalism and political decentralization. Thus, these forces are likely to reflect in its governance ethos. Historically, the American Revolution made many citizens in Chicago and elsewhere wary of any form of centralized governance. This development, coupled with the metropolitan area's long history of civic engagement, has resulted in a greater emphasis on private sector-led development and local autonomy.

Unlike Chicago, Accra belongs in the Global South and is a relatively less prominent player in the global economy. This notwithstanding, the city-region has an important role in the Ghanaian and West African economies, especially given its impressive levels of growth in the recent past. For instance, Accra is located on the shores of the Atlantic Ocean and is serviced by the neighboring Port of Tema. It also boasts of some of the best infrastructure in Ghana, such as major roads and the Kotoka International Airport (Howarth HTL, 2011: p. 2). As regards politics and pathdependency, Accra lies in a nation which has experimented with both socialism and capitalism at different points in its history. These political forces therefore may explain the governance paradigm of the metropolitan area. Historically, Ghana's colonial history, 
with its emphasis on the public sector as the primary driver of the development process resulted in a top-down administrative mechanism. This development has been transformed only in the recent past by economic and political reforms rolled out under International Monetary Fund and World Bank sponsored Structural Adjustment Programs. The result has been an increased engagement of the private sector, as well as administrative devolution to reduce over-centralization.

Two other reasons account for my choice of the metropolitan areas for this analysis. To begin with, Chicago and Accra are sister-cities. It will therefore be interesting to compare and contrast how two sister-cities in very different parts of the world respond to globalization (with respect to inter-local cooperation). These findings could form the bases for new forms of exchanges between the two metropolitan areas i.e. in terms of governance and development experiences. Moreover, my choice of Chicago and Accra has been informed by my familiarity with the two city-regions. This makes it possible for me to carry out a very thorough and well-informed analysis; one which will benefit from my personal insights, observations, and knowledge.

A number of possible limitations associated with the choice of Chicago and Accra would be addressed here. First, it may be argued that since Chicago is not a capital cityregion and Accra is, the analysis would be distorted. It must however be noted that many of the prominent global city-regions in North America are not national capitals. To cite an example, Washington DC, the capital of the United States, is not nearly as globalized as Chicago (the metropolitan area of choice for this analysis) because it is only an administrative capital. In many parts of Africa however, the most prominent globalizing urban agglomerations tend to be capital city-regions because these serve as both 
commercial and administrative capitals. It may also be claimed that insights gained from investigations of Chicago and Accra may not necessarily be generalizable to the situations in the Global North and South. This fact notwithstanding, it must be noted that in many respects, Chicago is a quintessential example when one thinks of a global cityregion in the Global North. With a critical mass of size and wealth, and a concentration of Fortune 500 companies, the metropolitan area constitutes a powerhouse in both the American and global economies. The story of Accra with respect to globalization in the Global South is also quite typical. This city-region hosts many subsidiaries or local branches of global firms.

It may also be argued that the blanket categorization of Chicago as belonging in the Global North and Accra as being in the Global South is problematic given the levels of spatial polarization in both metropolitan areas. Admittedly, as a result of this polarization, elements of the Global South exist in Chicago (especially on the South and West Sides), while aspects of the Global North can be found in Accra (especially in its Central Business District and wealthy suburbs). These facts notwithstanding, it is the thesis of this study that Chicago typifies a city-region in the Global North more than it does a locale in the Global South. On the other hand, Accra represents a metropolitan area in the Global South more than it does a city-region in the Global North. The wider economic, political, and historical frameworks associated with the two metropolitan areas lend credence to this assertion.

The Chicago -Naperville-Joliet metropolitan statistical area is a vast region comprising "Cook, DeKalb, DuPage, Grundy, Kane, Kendall, Lake, McHenry, and Will Counties in Illinois; Jasper, Lake, Newton, and Porter Counties in Indiana; and Kenosha 
county in Wisconsin" (U.S. Census Bureau, 2013). However, for the sake of feasibility and the thoroughness of the study, this research will focus on the six-county metropolitan area comprising Cook, DuPage, Kane, Lake, McHenry, and Will Counties. This area of study, which constitutes the limits of the Chicago city-region proper, hosts many multinational corporations and has been the focus of other similar research endeavors on regional cooperation. Also, the Greater Accra Region comprises two metropolitan assemblies (i.e. Accra and Tema), nine municipal assemblies (i.e. Ledzokuku-Krowor, La Dade-Kotopon, Adentan, Ashaiman, Ga Central, Ga West, Ga East, Ga South, and LaNkwatanang-Madina), as well as five district assemblies (i.e. Ada West, Dangme East, Shai-Osudoku, Ningo-Prampram, and Kpone-Katamanso). This study will however focus on the Greater Accra Metropolitan Area comprising the Accra and Tema Metropolitan areas, the Ledzokuku-Krowor, La Dade-Kotopon, Adentan, Ashaiman, and Ga municipal areas, as well as the La-Nkwantanang-Madina Municipality (Ministry of Local Government \& Rural Development - Ghana and Maks publications \& Media Services, 2006; Grant and Yankson, 2002; Ghana Statistical Service, 2010; The World Bank, 2010: p. 10). The Greater Accra Metropolitan Area was chosen because it constitutes the most urbanized part of the city-region where many multinational corporations are concentrated. The following table summarizes some basic demographics for the Chicago and Accra metropolitan areas, respectively. 
Table 3.1 Demographics for Chicago and Accra

\begin{tabular}{|l|l|l|}
\hline $\begin{array}{l}\text { Demographics/City- } \\
\text { Region }\end{array}$ & \multicolumn{1}{|c|}{ Chicago } & \multicolumn{1}{c|}{ Accra } \\
\hline Population & $\begin{array}{l}\text { 8,316,650 (2010 figure for } \\
\text { the Chicago Metropolitan } \\
\text { Area) }\end{array}$ & $\begin{array}{l}\text { 3,756,423 (2010 figure for } \\
\text { the Greater Accra } \\
\text { Metropolitan area) }\end{array}$ \\
\hline Land Area (Hectares) & $\begin{array}{l}\text { 60,000 (2010 figure for } \\
\text { Chicago city limits) }\end{array}$ & $\begin{array}{l}\text { 20,100 (2009 figure for } \\
\text { Accra Metropolis) }\end{array}$ \\
\hline $\begin{array}{l}\text { Globalization and World } \\
\text { Cities (GaWC) 2012 } \\
\text { Ranking }\end{array}$ & Alpha & Gamma- \\
\hline $\begin{array}{l}\text { Foreign Direct Investment } \\
\text { (FDI) }\end{array}$ & $\begin{array}{l}\text { \$570 million (Average } \\
\text { annual figure for 2003- } \\
2011)\end{array}$ & $\begin{array}{l}\text { \$256.92 million (July 2013 } \\
\text { figure for the Greater Accra } \\
\text { Region) }\end{array}$ \\
\hline Regional Cooperation & Complex networks & Multitiered/Hierarchical \\
\hline Rescaling & Decentralized & Centralized \\
\hline
\end{tabular}

(Sources: City of Chicago, 2010-2013; Ghana Statistical Service, 2012; UN-Habitat, 2008 \& 2009; Loughborough University - Department of Geography, 2010; Moskow and Osborn, 2012; Ghana Investment Promotion Center, 2013; Zhang, 2013; The World Bank, 2010; Orum, 2005; Ayee, 2012)

\subsection{Research Problem Definition}

A number of shortcomings in the reviewed literature justify the need for this research. To begin with, even though many studies have examined the interplay between global and local factors in urban development, a relative dearth exists with respect to regional cooperation in particular. For instance, works such as Cochrane et al. (1996), Wu (2003), Madon and Sahay (2001), Abrahamson (2004), Glaeser (2011), Beall (2002), Han et al. (2012), Doussard et al. (2009), and Robertson (1992 \& 1994) have looked at how global and local elements interact without specific reference to regionalism. Also, studies such as Tsukamoto and Vogel (2007), Yeung (2002), Kacowicz (1998), as well as Swyngedouw (2004), which examined the implications of globalization for regionalism focused on rescaling, without sufficient consideration for other matters (such as the 
nature of cooperation). These inquiries have also not paid much attention to the local context associated with the implications of globalization for rescaling. Moreover, studies such as Visser (2002), Feiock (2007), Andersen and Pierre (2010), Jung and Kim (2009), as well as Jacobs (2004), have investigated the important roles local factors play in regional cooperation without taking cognizance of the global context. Given the relative paucity of research on the differential implications of globalization for inter-local cooperation in different context-specific settings, this reality constitutes the primary problem for this study.

\subsection{Research Questions}

The questions designed to attain the objectives of this study are as follows:

1. What is the nature of globalization in Chicago and Accra, given their unique local contexts?

2. How do local factors in Chicago and Accra mediate the respective implications of globalization for the nature of regional cooperation in the two metropolitan areas?

3. How does the context-specific nature of each city-region influence the ramifications of globalization for rescaling? 


\subsection{Research Propositions}

The following are the propositions for the research, together with explanations regarding them:

1. Due to their unique economic, political, and historical contexts, globalization in Chicago and Accra will be different from each other.

As noted earlier, Chicago lies in the Global North and belongs in the core of global economic activity. Moreover, it is located in the United States, a nation whose political system and history stress the role of the private sector as the primary driver of economic growth. This study therefore posits that due to its strategic importance in the global economy, Chicago will serve as a headquarter location for major multinational corporations. Moreover, globalization would be associated with increased levels of foreign direct investment, mostly originating from the developed world. Chicago would also place more emphasis on the private sector and civic engagement in the global era. Unlike Chicago, Accra belongs in the Global South and is located in Ghana, a nation which had a history of socialism in the early years of independence and capitalism in the recent past. Accordingly, this study posits that as a result of its colonial and historical vestiges which have resulted in a relatively nascent stage of private sector engagement, Accra would mostly attract subsidiaries or local branches of global firms. The global era here would also be associated with increased levels of foreign direct investment, even though this will come from both the developing and developed worlds. Moreover, due to its long history of public sector-led development dating back to the days of colonialism, political globalization in Accra would most likely be in the form of administrative or institutional restructuring. 
2. The implications of globalization for the nature of regional cooperation in each metropolitan area will depend on its context-specific economy, political culture, path dependency, and history.

Chicago and Accra have entirely different context-specific economies, political cultures, path-dependencies, and histories. To begin with, Chicago places emphasis on private sector engagement and local autonomy. Thus, this study posits that the city-region would adopt a more flexible, voluntary, and informal approach to cooperation i.e. one based on the notion of "governance." These collaborative arrangements would not necessarily be associated with formal regional governmental structures and may lead to challenges when it comes to development coordination. The city-region's history will also emphasize the role of the private sector and economic competiveness in accordance with the American ethos of capitalism. Unlike Chicago, Accra lies in Ghana, a country whose long history of public sector-led development has been interspersed only in the recent past by a focus on the private sector. This study therefore hypothesizes that Accra would practice a more hierarchical and formal approach to collective action; one which is based on an institutional framework i.e. the notion of "government." These structures would seek to ensure a more coordinated and directed approach to regionalism. Moreover, the public sector and political actors are likely to play more prominent roles when it comes to regional cooperation. 
3. The ramifications of globalization for rescaling in each city-region will be shaped by its context-specific political culture, path dependency, and history.

This study posits that due to American revolutionary origins which made many citizens wary of centralization, the Chicago metropolitan area will experience resistance to annexation in its efforts to expand outwards. Thus, the city-region will be associated with decentralized and autonomous governance associated with mayoral politics. The result will be a highly fragmented political landscape in the global era. On the other hand, as a result of its colonial vestige which placed little or no emphasis on local autonomy, Accra will expand outwards to encompass adjoining territories. This will result in a centralized government which stresses the national interest and is associated with high levels of national government control. Thus, bureaucracy will be the dominant development in the global era.

\subsection{Variables and Data}

The main independent variable in the analysis is globalization. Various secondary and primary sources would be used to analyze this phenomenon. The nature of globalization will be discussed with respect to the presence of global service firms, foreign direct investment, public-private partnerships, civic engagement, and institutional restructuring. Analyzing the presence of global service firms and foreign direct investment gives a sense of a metropolitan area's integration into the global economy. Moreover, public-private partnerships and civic engagement help to assess the extent to which a city-region's level of globalization is linked up with private capital. Also, 
institutional restructuring can give an idea about the administrative nature of the political globalization process, especially in the Global South. Apart from globalization, other independent variables in the analysis include the context-specific factors (i.e. economies, political cultures, path dependencies, and histories) of Chicago and Accra, respectively. Data on these will be compiled from secondary and primary sources. Also, data on the inter-local cooperation (i.e. the dependent variable) will be obtained from various secondary sources. Primary data (obtained from interviews in Chicago and Accra) would be used to supplement the secondary data. Inter-local cooperation will be analyzed with respect to the nature of regional cooperation (i.e. flexible/informal or hierarchical/formal), as well as the nature of rescaling (i.e. resistance to annexation or expansion; decentralization or centralization). These will help to clearly pinpoint differences in Chicago and Accra with respect to the implications of globalization for regionalism.

\subsection{Research Methodologies}

This section focuses on the methodologies adopted in the research. Specifically, discussions will look at the case study approach, critical realism, comparative methodology, and qualitative analysis.

\subsubsection{Case Study Approach}

A case study approach will be employed in this inquiry. As the name suggests, this method entails a detailed and grounded examination of a particular scenario (Feagin 
et al., 1991: p. 2). Thus, while studies based on generalizability look at issues in greater breadth or scope, case studies examine particular subjects in greater depth. This happens in part because it is difficult to simultaneously investigate all matters in detail due to time, money, and other resource constraints. However, selecting individual cases make such in-depth studies viable (Flyvbjerg, 2006: pp. $220 \&$ 237). The case study methodology is a feasible approach for observing societies and phenomena in their realworld contexts (Feagin et al., 1991: pp. 7-8). Case studies are also useful in the social sciences because disciplines in this area, unlike those in the natural sciences, do not have single paradigms guiding the direction of scholarship and research. It is therefore important to examine various scenarios with respect to their contextual settings as a way of gaining new insights about the way things work out in different situations (Flyvbjerg, 2006: p. 223; Feagin et al., 1991: pp. 7-8).

Case studies are usually based on qualitative methodological approaches as a result of the imperative to elaborate on phenomena. Thus, they enhance understanding regarding existing theoretical frameworks. They may also contribute to enriching the prevailing discourse because they examine how findings in specific contexts serve to confirm or refute theories (Feagin et al., 1991: pp. 13-14). Case studies (even in situations where they represent outliers to prevailing general trends) throw new light on why situations in particular contexts differ from the general situation. They may therefore serve as grounds for revising or modifying current schools of thought (Flyvbjerg, 2006: p. 229). Case studies are also useful in research involving historical accounts of phenomena as they give detailed explanations of how and why things happen the way they do at specific time periods (Feagin et al., 1991: pp. 12-13). 
Case study evaluations consist of five main parts. First, there must be clearlydefined research questions in line with the objectives of the inquiry. These questions seek to address "what," why," "how," and/or "when" issues (Yin, 2014: p. 29). Second, case studies involve research hypotheses or posits. These hypotheses address the research questions at hand by steering the course of inquiry in very particular directions (Yin, 2014: p. 30). Third, case study research comprises the case or scenario under examination. This can range from persons or societies to firms/institutions or places (Yin, 2014: p. 31). Fourth, clear relationships must be established between the relevant data and research hypotheses. This helps to answer the research questions, so that the goals of the inquiry can be attained (Yin, 2014: p. 36). Fifth, case studies should have welldefined yardsticks for evaluating findings. These tools may take cognizance of prevailing research, as a way of either aligning one's findings with what exists or distinguishing them from other studies (Yin, 2014: p. 36).

On the one hand, case study examinations may occur as stand-alone investigations meant to discover as much as possible about a single phenomenon or scenario of interest. These endeavors could be described as belonging in a "realist orientation" (Yin, 2014: p. 17). On the other hand however, case studies may involve investigations of multiple phenomena or scenarios. In such situations, they are referred to as a "relativist orientation" (Yin, 2014: p. 17). Where they examine multiple instances, case studies tease out comparisons based on clearly-defined criteria which form the bases of comparison as regards the subjects under investigation. These criteria may be informed by the research questions, as well as dominant themes in prevailing works (Eisenhardt, 2002: p. 18). Alternatively, case study evaluations may simply compare and contrast the specific 
elements being examined with the object of finding out any commonalities and dissimilarities which may exist (Eisenhardt, 2002: pp. 18-19). Here, the researcher keeps an open mind and seeks to unearth salient information which may otherwise be ignored (Eisenhardt, 2002: p. 19). Moreover, the various data sources employed in investigations can be examined separately in order to assess any prevailing differences among the scenarios of interest. For instance, while secondary data sources may reveal one aspect of a case, primary data such as interviews help to unravel other dimensions like human impressions and experiences not covered by the secondary data (Eisenhardt, 2002: p. 19).

\subsubsection{Critical Realism}

The notion of a case study ties in well with that of critical realism, the primary analytical framework for this research. This is because, both approaches stress the need to gain useful insights based on a grounded approach to inquiry (Feagin et al., 1991: pp. 78). Critical realism argues that "the world is composed not only of events, state of affairs, experiences, impressions, and discourses, but also of underlying structures, powers, and tendencies that exist" (Patomäki and Wight, 2000: p. 223). Thus, happenings or phenomena are explained, not simply in terms of results observed, but also by means of the contextual underpinnings associated with them. Critical realism observes that the world is an elaborate web of cause-and-effect relationships characterized by intricate frameworks and power dynamics (Patomäki and Wight, 2000: p. 223). Specifically, it evaluates "social processes and events in terms of the causal powers of both structures and human agency and the contingency of their effects" (Fairclough, 2005: pp. 922-923). This school of thought is based on "retroduction," rather than "induction" or "deduction" 
(Patomäki and Wight, 2000: pp. 223-224). That is, it asserts that phenomena should be investigated to reveal hidden meanings or explanations for why things exist the way they do (Patomäki and Wight, 2000: p. 224). Critical realism may be based on principles such as "ontological realism" and "epistemological relativism" (Patomäki and Wright, 2000: p. 224). Ontological realism asserts that actual events exist and that these may be dependent on context and embedded in wider societal frameworks. Epistemological relativism observes that the social context within which phenomena are generated makes their relevance susceptible to change (Patomäki and Wright, 2000: p. 224).

In contributing to the discourse on critical realism, Sayer (1992: p. 5) observed that the world functions notwithstanding man's level of understanding concerning it at any point in time. This world is composed of frameworks defined by power dynamics inherent in various social constructions (Sayer, 1992: p. 5). In other words, the frameworks are context-specific and derive their orientations from the wider sociocultural configurations within which they are embedded (Sayer, 1992: pp. 5-6). They therefore beg for in-depth research endeavors aimed at unearthing hitherto unknown cause-and-effect relationships associated with these constructions. While the researcher's insights could prove useful in explaining relationships, they are present irrespective of the investigator's novelty (Sayer, 1992: p. 6). The research endeavors associated with critical realism must be grounded in empiricism as a way of effectively accounting for the phenomena they intend to explain (Sayer, 1992: p. 5).

The central defining goal of critical realism is to explain why things turn out the way they do in specific contexts. Towards accomplishing this, the "entities" or "objects" about which inquiries are being made must be clearly defined (Easton, 2010: p. 120). 
These may include societies, institutions, and/or inter-governmental networks. It is important to note that entities may be rooted in structures, which could be further implanted in other structures (Easton, 2010: p. 120). Having defined the entities, one must also consider the "outcomes" or "events" associated with these entities, about which causal relationships are being sought (Easton, 2010: p. 120). The inquiry then evaluates the means through which the entities or objects of interest account for the noted outcomes (Easton, 2010: p. 122). Specifically, it asserts that "mediating entities are necessary to account for the relationship between structures and processes/events" (Fairclough, 2005: p. 922). One additional issue worthy of note is that "different levels of aggregation" may explain the entities of interest (Easton, 2010: p. 121). That is, these objects should not simply be regarded as amalgams of their components. In a governmental set-up for instance, the levels of responsibility associated with various forms of exchange result in noted outcomes (Easton, 2010: p. 121).

According Yeung (1997), the notion of critical realism may be based on three main methodological approaches. First, a process of "iterative abstraction" can be conceived (Yeung, 1997: p. 58). This seeks to model real-life phenomena by means of specific causal factors which are deemed necessary for explaining the dependent variable at hand (Yeung, 1997: p. 58). It zeroes in on the most relevant variables, while ensuring at the same time that indicators are not ignored simply due to a lack of interest on the part of the researcher (Yeung, 1997: p. 59). Besides iterative abstraction, critical realism may also be based on "grounded theory" (Yeung, 1997: p. 61). This approach collects data from the field in order to ensure that a particular research endeavor has a strong empirical basis. It is useful for evaluating the social constructions associated with both structure 
and human agency. Thus, it constitutes a useful bridge to the method of iterative abstraction which is predominantly focused on theory (Yeung, 1997: pp. 61-62). Critical realism may also be premised on a third methodological approach known as "triangulation" (Yeung, 1997: p. 64). Triangulation means adopting a variety of approaches in order to enhance the analytical rigor of the research. These may include an exploratory approach, discourse analysis, and field research as a way of ensuring that the shortcomings in one approach are compensated for by the strengths in another (Yeung, 1997: p. 64).

\subsubsection{Comparative Analysis}

This research examines two case studies (based on critical realism) within a comparative framework. Comparative analysis elaborates on phenomena in different spatial contexts as a way of pointing out similarities and differences. Specifically, it explains why economic, political, and socio-cultural factors manifest themselves in particular ways (Denters and Mossberger, 2006: p. 552). Second, comparative analysis makes up for the inability of the social sciences to undertake experiments under strict laboratory settings where different elements can be isolated and contrasted with each other. In the real world therefore, comparing and contrasting phenomena in different places comes across as a more feasible approach (Denters and Mossberger, 2006: p. 553). Third, comparative analysis may be employed in order to discover broader trends with respect to the subjects of interest. Thus, while it may not always be possible to make generalizations from them, these inquiries nevertheless help us to better understand the general underpinnings of phenomena than would be the case if studies were confined to 
only one location (Denters and Mossberger, 2006: p. 552). Fourth, comparative analysis points out the strengths and shortcomings associated with the way subjects operate in various places as a way of making recommendations for improvement if the need be (Denters and Mossberger, 2006: p. 553).

Towards enhancing the rigor and validity of comparative analysis, a number of methodological challenges must be overcome. To begin with, the researcher must strike a healthy balance between the breadth and level of detail associated with the inquiry. That is, while it is important to select at least a handful of cases, this must not affect the meticulous nature of the analysis which distinguishes case studies from other research endeavors (Kantor and Savitch, 2005: p. 137). Moreover, comparative analysis must explain observed differences among jurisdictions in light of their different settings or circumstances. In other words, trends observed in one place should not simply be extrapolated in another without due regard for the economic, political, historical, and other factors which account for differential outcomes (Kantor and Savitch, 2005: p. 137). Similarly, concepts employed in a comparative analysis must appreciate the various meanings which may be associated with them in different places. For instance, in countries such as the United States, the notion of decentralization involves the transfer of power to local authorities, with a concomitant discontinuation of financial support by the federal government (Kantor and Savitch, 2005: p. 139). In France however, the concept connotes a greater involvement by localities in decision-making and inter-jurisdictional collaboration, with the central government still lending a helping hand financially (Kantor and Savitch, 2005: pp. 139-140). 
In times past, comparative investigations within the urban realm usually focused on cities in the same nation (Sellers, 2005: pp. 419-420). As a result, the national framework within which outcomes in cities could be contextualized was largely ignored in these analyses. Recently however, the advent of globalization has changed this development (Sellers, 2005: p. 420). This has occurred because researchers have increasingly resorted to analyses of cities in different nations with the object of teasing out global and regional trends. These investigations take into account the national contexts within which urban policies are fashioned out and implemented (Sellers, 2005: p. 420). The respective national frameworks therefore account for differential economic, political, and historical factors observed (Sellers, 2005: p. 420). Moreover, nation-states define the legal or regulatory environments within which cities operate in the global economy (Sellers, 2005: p. 420).

\subsubsection{Qualitative Approach}

Beside the comparative method, this study adopts a qualitative analytical approach. Unlike the quantitative technique which is more focused on a pre-defined and fixed approach to analyzing phenomena, a qualitative approach is more flexible in its methodology (Bryman, 1984: p. 78). The flexible and narrative nature of the qualitative method makes it a good approach to adopt in the analysis of phenomena within contextspecific settings (Bryman, 1984: p. 78). In other words, because quantitative approaches are based on fixed rules for identifying relationships between or among phenomena, they may not be very well-suited where the focus of a piece of research is to understand why things work the way they do within particular environments (Bryman, 1984: p. 78). 
Qualitative approaches, unlike quantitative methodologies, provide rich or detailed information recounting the various dimensions of phenomena i.e. economic, political, and historical among others, based on their relevance for explaining the situation at hand (Bryman, 1984: pp. 78 \& 79).

Specifically, this study employs qualitative techniques such as historical, descriptive, and exploratory methods, as well as discourse analysis to answer its questions. Historical research methods observe patterns over time as a way of discovering trends and making postulations about the future. They give a chronological evaluation of phenomena in order to understand their economic, political, and socio-cultural underpinnings. The observations in one place or locality may serve as a useful basis for comparison with what prevails elsewhere (Feagin et al., 1991: pp. 5 \& 12; Berg, 1995: pp. 161-162). This helps to pinpoint similarities and differences as a basis for evaluating how local contexts account for the evolution of phenomena (Feagin et al., 1991: p. 5). Historical research techniques are useful because in order to understand phenomena as they currently exist, it is important to examine the choices made and actions embarked upon in the past. This helps to assess the rationale which characterized decision-making at different time periods, as well as how these have changed over time. Moreover, an appreciation of the history of policy and decision-making would serve to better inform the choices made by current and future generations (Feagin et al., 1991: pp. 5 \& 12; Berg, 1995: pp. 161-162).

With respect to the other qualitative approaches, descriptive research techniques are useful for articulating information because they are focused on outlining the attributes or characteristics of phenomena (Sandelowski, 2000: p. 335). Descriptive research is a 
useful first step towards laying the groundwork for more detailed analyses. This is because it gives a "big picture view" of situations without going too much into their details (Sandelowski, 2000: p. 335). This research primarily adopts an exploratory approach. Unlike descriptive techniques, exploratory methods help to elaborate on the reasons undergirding the way phenomena operate. These techniques therefore involve indepth discussions and make useful contributions towards enriching and even expanding the existing body of knowledge (Eisner, 1997: p. 264). They are a useful approach to adopt in qualitative analyses because they provide the kind of rich and detailed information which makes the qualitative approach suitable for the examination of phenomena within context-specific settings (Bryman, 1984: p. 78).

Discourse analysis is a technique which relies on texts and socio-cultural constructions to draw conclusions (Rose, 2001: pp. 135-136). Texts, as defined here, refers to resources in a written format, usually obtained from secondary data sources such as books, reports, and journal articles (Rose, 2001: pp. 135-137). Moreover, sociocultural constructions involve the customs and usages associated with particular societies which distinguish them from others. Discourse analysis examines these data sources indepth in order to establish linkages or make observations which may not be easily identifiable at first glance (Rose, 2001: pp. 135-137). It takes cognizance of the institutional frameworks associated with particular socio-cultural practices and seeks to situate these at the interface between power relations and the generation of knowledge. These frameworks comprise laws, networks, and practices defined over time by various actors (Rose, 2001: p. 166). Discourse analysis also opines that places have tremendous meanings derived from their historical backgrounds which are embedded in their cultural 
orientations. These meanings can only be unearthed by detailed inquiries which take into account the context-specific underpinnings characteristic of their socio-cultural manifestations (Forbes, 2000: p. 126).

Beside the primary sources of data, this study also carries out interviews because they are a practical way of investigating human perceptions, impressions, and/or experiences. This usefulness arises from the fact that they enable the researcher to speak directly to human subjects and benefit from their personal insights (Schutt, 2012: p. 264). Besides, interviews by their nature help to obtain detailed information from the subjects of interest. This enables one to effectively answer the research questions given the depth of information available (Schutt, 2012: p. 264). Interviews are also a useful technique to employ because they make it possible for the researcher to explain questions directly to the respondent in case there is anything they do not understand. As a result, the investigator can be more certain about the veracity of the responses obtained. However, as a result of their engaging nature, interviews appear more suitable in studies which involve relatively small sample sizes (Schutt, 2012: p. 264). This study employs interviewing to evaluate the perceptions and experiences of a handful of members in the business and investment community, as well as local officials in Chicago and Accra.

A total of forty people (i.e. twenty in each city) were contacted for possible interviews in connection with this study. Contacts were made mostly by e-mail and phone in the case of Chicago. For Accra, phone calls by the researcher and follow-up visits by the researcher's aide were adopted for the initial interaction. Out of the total number contacted in both cities, twenty-one responded to the initial request, with ten of them eventually agreeing to be interviewed in connection with this research. Thus, a total of 
ten interviews (i.e. five in each metropolitan area) were carried out for this study. For each city-region, the respondents comprised two prominent members from the business and investment community, as well as three local/planning officials. In Chicago, the respondents included two top business/investment officials: one at the British American Business Council and the other at the Illinois Department of Commerce and Economic Opportunity. Three senior local officials were also interviewed i.e. one each from the Metropolitan Mayors' Caucus, the Chicago Metropolitan Agency for Planning, and the Metropolitan Planning Council. The respondents in Accra included two senior business/investment officials: one at the Ghana Investment Promotion Center and the other at the Ghana National Chamber of Commerce and Industry. Also, three senior local/planning officials were interviewed i.e. one each from the Accra Metropolitan Assembly, the Tema Metropolitan Assembly, and the Greater Accra Regional Coordinating Council. The interviews were carried out in conformity with ethical standards spelt out by the Institutional Review Board (IRB) of the University of Louisville. For instance, an "informed consent" was read out to each respondent before the interview. Moreover, all the participants were guaranteed anonymity in the reporting of the findings of this study.

In the case of Chicago, four out of the five interviews were conducted face-toface, with the remaining interaction taking place by phone. The researcher embarked on two separate trips to the city for the in-person interviews. All of the interviews conducted in Accra took place by phone, even though the researcher's aide was with the respondents in person and taking notes during the conversations (as a way of ensuring triangulation of responses). The researcher took detailed notes in the course of all ten interviews and was 
allowed to record four of them with permission from the respondents. Questions asked in the interviews for members of the business and investment community focused on globalization in the two city-regions (with respect to foreign direct investment, the presence of global service firms, and neoliberal policies). For the second group of interviews comprising local/planning officials, questions assessed whether or not localities in the two metropolitan areas cooperate and how the trend towards collaboration has evolved over the years. They also examined the respective approaches by Chicago and Accra to metropolitan governance/government.

\subsection{Summary}

This chapter has examined research methodological issues. It elaborated on the rationale for the choice of the study areas and defined the research problem as filling the dearth in existing studies with respect to the global-local nexus in regionalism. The research questions and propositions discussed by the chapter may be summarized as follows: exploring how the differential economies, political cultures, path dependencies, and histories of Chicago and Accra influence the ramifications of globalization for their respective approaches to regional cooperation and rescaling. The chapter also looked at the dependent and independent variables and concluded by throwing more light on the case study approach, critical realism, comparative analysis, and qualitative methods. Chapter 4 discusses differences in the globalization of Chicago and Accra, given their local contexts. 


\section{CHAPTER 4}

\section{GLOBALIZATION IN CHICAGO AND ACCRA}

Overview

This chapter examines the nature of globalization in Chicago and Accra. It looks at the presence of global service firms, foreign direct investment, public-private partnerships, civic engagement, and institutional restructuring as a way of evaluating the respective footholds of the two city-regions in the global economy. Moreover, it traces the economic and political evolution of globalization in Chicago and Accra in order to understand how the phenomenon emerged differently in the two metropolitan areas.

\subsection{Comparing Globalization in Chicago and Accra}

A number of observations can be made about globalization in Chicago and Accra. To begin with, Chicago, like many major city-regions in the United States, has a long history of private sector engagement, resulting in a high level of global economic integration. In the case of Accra, the involvement of the private sector in the development of the metropolitan area is relatively recent. Thus, the city-region's incorporation into the global economy is at a relatively nascent stage. It is also important to note that Chicago has a history of political and civic engagement, dating back many decades. This leads to the engendering of local autonomy. In the case of Accra, there has been a relatively recent participation of civil society in the governance process, implying that the central 
government has typically dominated the political landscape. As a result of these differences, political globalization in Chicago is characterized by voluntary cooperation and fragmentation, while that in Accra is associated with an institutional approach to regionalism and centralization. Generally speaking therefore, the distinctive nature of globalization in Chicago and Accra may be attributed to their respective economic, political, and historical contexts. The table below summarizes globalization in the two metropolitan areas:

Table 4.1 Globalization in Chicago and Accra

\begin{tabular}{|l|l|l|l|}
\hline $\begin{array}{l}\text { Element of } \\
\text { Globalization }\end{array}$ & $\begin{array}{l}\text { Both Chicago and } \\
\text { Accra }\end{array}$ & Chicago & Accra \\
\hline Ranking & $\begin{array}{l}\text { Globalization and } \\
\text { World Cities Index }\end{array}$ & Alpha & Gamma- \\
\hline $\begin{array}{l}\text { Presence of global } \\
\text { firms }\end{array}$ & $\begin{array}{l}\text { Attraction of global } \\
\text { capital }\end{array}$ & $\begin{array}{l}\text { Headquarter } \\
\text { location }\end{array}$ & $\begin{array}{l}\text { Location for } \\
\text { subsidiaries or } \\
\text { local branches of } \\
\text { global firms }\end{array}$ \\
\hline Service sector & $\begin{array}{l}\text { Growth in service } \\
\text { sector }\end{array}$ & $\begin{array}{l}\text { Long-established } \\
\text { firms }\end{array}$ & $\begin{array}{l}\text { Relatively nascent } \\
\text { firms }\end{array}$ \\
\hline $\begin{array}{l}\text { Foreign direct } \\
\text { investment }\end{array}$ & $\begin{array}{l}\text { Increase in foreign } \\
\text { direct investment }\end{array}$ & $\begin{array}{l}\text { Comparable to } \\
\text { other major } \\
\text { American cities; } \\
\text { Mostly originate } \\
\text { from Global North }\end{array}$ & $\begin{array}{l}\text { Heavy } \\
\text { concentration of } \\
\text { investments here; } \\
\text { Emanate from } \\
\text { both Global North } \\
\text { and South }\end{array}$ \\
\hline $\begin{array}{l}\text { Political/Institutional } \\
\text { Arrangements }\end{array}$ & $\begin{array}{l}\text { Public-private } \\
\text { partnerships }\end{array}$ & $\begin{array}{l}\text { Private sector } \\
\text { involvement and } \\
\text { civic engagement }\end{array}$ & $\begin{array}{l}\text { Public sector } \\
\text { involvement and } \\
\text { institutional } \\
\text { restructuring }\end{array}$ \\
\hline
\end{tabular}

(Source: Author's construct based on literature, discourse analysis, and interviews)

According to the Globalization and World Cities (GAWC) Index for 2012, Chicago is an alpha city. These are described as "very important cities that link major 
economic regions and states into the world economy." As evident from earlier statements, this categorization may be explained by Chicago's long history of private sector engagement which has attracted many global firms to the metropolitan area over the years. Unlike Chicago, Accra is categorized as a gamma minus city. This classification refers to "world cities linking smaller regions or states into the world economy, or important world cities whose major global capacity is not in advanced producer services." The depiction of Accra as a gamma minus city may be due to its recent engagement of the private sector, implying that relatively speaking, it occupies a smaller portion of the global economy.

Globalization in Chicago and Accra is manifested differently with respect to the corporate geography of global firms. To begin with, Chicago serves as a headquarter location for several multinationals and Fortune 500 companies. These include Boeing, United Continental Holdings, and Anixter International. The headquarter locations of these global firms in Chicago is due in part to the city-region's strategic location in the Midwest which makes it a hub for air, rail, and water transportation. Moreover, there are agglomeration economies associated with operating in Chicago because it is a renowned destination for global economic activity. In the case of Accra, the city-region primarily serves as a location for local branches of global firms. These include subsidiaries of corporate entities such as Goldfields Ltd, Newmont Ltd, British American Tobacco, and G4S Security Services. The role of Accra as a location for branches, rather than head offices of global firms may be due to its status as a city in an emerging economy, as well as its relatively recent history of private sector engagement. This fact notwithstanding, the city-region is gradually emerging as a headquarter location for budding multinationals 
such as Databank Financial Services and RLG Communications. Thus, great potential exists for the metropolitan area to become a more prominent global player in the future.

The global era has also resulted in the increased prominence of the service sector in the economies of both Chicago and Accra. In the case of Chicago, this occurred as the city-region sought to reinvent itself in the 1980s and 1990s, following the phenomenon of deindustrialization which swept across many metropolitan areas in the United States. The result has been the proliferation of service firms in various sectors such as information technology, finance, and law. The rise of the service sector marked a new phase in a long history of private sector-led development within the city-region in particular and the United States in general. Thus, many of these firms are prominent global players. With respect to Accra, growth in the service sector mostly occurred in the 1980s and 1990s as Ghana sought to stem the tide of economic decline through Structural Adjustment Programs (SAPs) rolled out under the auspices of the Bretton Woods institutions. This development marked a paradigm shift, as the nation had hitherto placed emphasis on the public sector as the driver of development. As a result of this, many of the service firms found in the metropolitan area appear to be relatively nascent in their stage of operations.

Both Chicago and Accra have witnessed the heightening of spatial polarization in their regional and national contexts. This is due, at least in part, to concentrations of the operations of global firms in specific territorial domains, to the virtual exclusion of others. In the case of Chicago, the regional context of polarization is evident because while the downtown area and other business districts continue to thrive, places such as the South and West sides wallow in poverty. At the national level, the global era has witnessed great concentrations of economic activity in the Chicago metropolitan area 
(similar to what prevails in other major city-regions such as New York, Los Angeles, and Houston). As a result, Chicago (just like these other metropolitan areas) occupies a very prominent position in the global economy. For instance, its Gross Regional product of $\$ 531$ billion matches those of powerful nations such as Sweden and Belgium (World Business Chicago, 2014). With respect to Accra, the global era has witnessed the perpetuation of poverty in places such as Chorkor, Nima, and Mamobi, while areas like East Legon, Cantonments, and Roman Ridge continue to thrive. Unlike Chicago, Accra is Ghana's primate city and is therefore associated with a high concentration of most of the nation's economic activity in the global era. This has occurred due to initiatives by various governments since independence to promote the city-region as the "growth pole" for the national economy. It is also important to note that unlike Chicago which occupies a predominant role in the global economy, Accra plays a relatively less prominent part due to its recent engagement with the private sector. This notwithstanding, the cityregion's phenomenal growth in the recent past means the potential exists for it to become a major player in the global economy in the future.

Another area where some notable differences exist between Chicago and Accra is with respect to inflows of foreign direct investment. Chicago is one of several American city-regions which attract appreciable levels of foreign direct investment. Thus, other places such as New York, Houston, and Los Angeles compete with this metropolitan area for investment. The fact that Chicago is not the only American metropolitan area with appreciably high levels of foreign direct investment may be explained by the fact that the United States is "a confederacy of regional metropolises" (Warner, 1987: p. ix). As a result, the nation is not dominated by just one major city-region, as prevails for instance 
in Europe and many developing nations. It must also be noted that much of Chicago's foreign direct investment originates from ten developed nations namely the United Kingdom, Canada, Japan, Ireland, France, Germany, Australia, Italy, Switzerland, and Sweden. This may be explained by the pursuit of North-North cooperation (part of which entails an investment component), as well as Chicago's important role within the global economy. In the case of Accra, as much as 80 plus percent of Ghana's foreign direct investment inflows come into this city-region alone. This is due to its status as a primate city and the engine around which the national economy revolves. Moreover, foreign direct investment inflows into Ghana in general and Accra in particular are associated with a host of developed and developing nations from across various parts of the world. For instance, the United Kingdom and United States accounted for the highest foreign capital inflows (associated with investment) between 1994 and 2009. However, developing nations such as China, India, and Lebanon recorded the highest levels of registered investment projects in Ghana during the same time period. The important roles of nations such as China and India when it comes to foreign direct investment in Ghana may be explained by the spirit of South-South cooperation, as well as the continuous rise of these two nations on the international stage, particularly in Africa.

The status of Chicago as a global city-region has also been enhanced by the presence of organizations committed to this course. For instance, World Business Chicago and The Chicago Council on Global Affairs have been at the forefront (in this respect). Moreover, the global era has brought in its wake a flurry of public-private partnerships thereby helping to cement the crucial role of Chicago's private sector in the development of the metropolitan area. The importance of private agencies in the planning 
and development of the city-region can also not be discounted. Some of these bodies (such as the Civic Consulting Alliance) bring together various actors towards coordinating development agendas with local and regional dimensions. Also, regional planning in Chicago within the global era is largely carried out under the auspices of various private entities. While the plans drawn by these bodies are not legally binding, they demonstrate that in many respects, political globalization in Chicago is strongly linked up with private capital and actors. Moreover, regional endeavors in relation to the provision of public services are carried out largely in conjunction with players in the private sector.

In the case of Accra, political globalization has largely been of an institutional nature. This is partly due to the bureaucratic nature of the governance process, a situation going back to the days of British colonial rule. Institutional restructuring has therefore emerged in the global era as a viable way of improving administrative efficiency in order to cut down on red tape. Moreover, the institutional nature of political globalization also appears to suggest that relatively speaking, globalization is less linked up with private capital and actors than is the case in Chicago. Admittedly, the case can be made that in many developed societies in Europe for instance, notwithstanding the advanced nature of the globalization process, political globalization is also largely institutional in nature. Even though this fact is true, the strength of my argument with respect to Accra lies in two main factors: the relatively recent engagement of the private sector in the cityregion's development and the fact that more bureaucracy is associated with government machinery in the developing than developed worlds. Thus, even though appreciable 
progress has been made with respect to public-private partnerships in the recent past, metropolitan governance is in most respects a public (rather than private) endeavor.

When evaluated in light of Sassen's global city model, a number of observations can be made about globalization in Chicago and Accra. To begin with, the phenomenon is indeed associated with both the dispersal and integration of the activities of multinational corporations. As evidenced particularly in the case of Chicago, the need for headquarter functions with respect to the coordination of the activities of these global firms has transformed the city-region into a focal point for global economic activity. The role of Chicago as a headquarter location has also been facilitated by its rich history as a primary business destination, as well as its strategic location in the U.S. Midwest. Sassen's analysis also appears very relevant with respect to the presence of branch offices in Accra. Given its business-friendly nature and important role as a hub for economic activity in West Africa, the metropolitan area continues to be a primary destination for many subsidiaries or local branches of global firms in this region. The concentrations of these corporate entities within the Central Business Districts of both Chicago and Accra lend credence to the notion of agglomeration economies associated with the work of Sassen. Moreover, Sassen's postulation concerning spatial polarization was evident in both Chicago and Accra. In the two city-regions, downtown and financial districts continue to prosper, while other portions of the metropolitan areas either remained the same or became poorer.

One area where Sassen's work may be critiqued is its bias towards metropolitan areas in North America and Western Europe. Undeniably, many of the postulates in the global city model, as explained in the preceding paragraph, apply to both Chicago and 
Accra. However, some notable differences exist between the two city-regions; and these in my opinion lend credence to the argument that Sassen's model did not sufficiently take into account the roles of local contexts in explaining the differential outcomes associated with globalization in cities. With specific reference to Chicago, the city-region's preeminent role in the American Midwest, coupled with a long history of private sector-led development, has accounted for its global status. And in the case of Accra, the metropolitan area's location in a developing region, vis-à-vis a long history of publicsector led development, have played major roles in shaping its course as a globalizing, rather than a full-fledged global city-region. In my opinion therefore, globalization in urban areas, while extra-local in its origins, is a largely local manifestation (as it is defined by the contexts associated with particular territorial domains).

The observations made about globalization in Chicago and Accra may also be understood in terms of the analyses by Brenner (1999a and 1999b) and Swyngedouw (2004). These scholars argue that globalization leads to the upward scaling of power away from the nation-state to supra-national forces, as well as downward scaling to localities and regions. Their arguments were confirmed in the case of Chicago and Accra because extra-national actors/forces (such as global firms and foreign direct investment) have increasingly become important players in the development of the two metropolitan areas. However, the extent to which these upward and downward scaling occurred depended very much on the unique local contexts of the two city-regions. In the case of Chicago, factors such as the American ethos of private sector-led development and strong mayoral politics have resulted in the emergence of the city-region as a headquarter location for global service firms. And for Accra, a long history of public sector-led 
development and a relatively recent engagement of the private sector have led to the cityregion mostly emerging as a location for subsidiaries of global firms. These conclusions suggest that the works by Brenner (1999a and 1999b) and Swyngedouw (2004) did not sufficiently take into account the roles local factors play in the upward and downward scaling of power away from the nation-state.

\subsection{Globalization in Chicago}

Chicago ranks highly on many indices of globalization, including the Globalization and World Cities (GAWC) Index. Many studies on globalization in cities have focused on the internal dynamics of these metropolitan areas due to the implications of the phenomenon for internal urban geography. The GAWC Index seeks to address this dearth in research by examining the relationships between a city and other world cities (Department of Geography - Loughborough University). Specifically, the classification relies on office networks by corporate entities which provide advanced producer services. It ranges along the following continuum, from the highest to the lowest rank: alpha ++ , alpha + , alpha, alpha -, beta + , beta, beta -, gamma +, gamma, gamma -, high sufficiency, and sufficiency. In 2000, 2004, 2008, and 2012, the GAWC Index ranked Chicago as an alpha city due to its prominent role in the global economy. This places it in the third tier of cities just behind New York and London (in the first tier), and Hong Kong and Paris (in the second tier). However, this represented a slight drop from its 2010 ranking as an alpha + city by the same index. The slight drop may be due to the fact that the GAWC Index is a constant work-in-progress which seeks to better rank cities based on available data at any point in time. Chicago has also been highly ranked in many other 
outlets. For instance, it places seventh in the 2014 Global Cities Index compiled by A. T. Kearney in conjunction with the Chicago Council on Global Affairs and Foreign Policy Magazine (Table 4.2). This index analyzes 26 variables in major cities around the world based on five indicators namely: "business activity, human capital, information exchange, cultural experience, and political engagement” (A. T. Kearney, 2014: p. 2).

Table 4.2 Twenty Leading Global Cities

\begin{tabular}{|c|c|c|c|c|}
\hline & \multicolumn{4}{|c|}{ Global Cities Ranking by Year } \\
\hline City & 2014 & 2012 & 2010 & 2008 \\
\hline New York & 1 & 1 & 1 & 1 \\
\hline London & 2 & 2 & 2 & 2 \\
\hline Paris & 3 & 3 & 4 & 3 \\
\hline Tokyo & 4 & 4 & 3 & 4 \\
\hline Hong Kong & 5 & 5 & 5 & 5 \\
\hline Los Angeles & 6 & 6 & 7 & 6 \\
\hline Chicago & 7 & 7 & 6 & 8 \\
\hline Beijing & 8 & 14 & 15 & 12 \\
\hline Singapore & 9 & 11 & 8 & 7 \\
\hline Washington & 10 & 10 & 13 & 11 \\
\hline Brussels & 11 & 9 & 11 & 13 \\
\hline Seoul & 12 & 8 & 10 & 9 \\
\hline Toronto & 13 & 16 & 14 & 10 \\
\hline Sydney & 14 & 12 & 9 & 16 \\
\hline Madrid & 15 & 18 & 17 & 14 \\
\hline Vienna & 16 & 13 & 18 & 19 \\
\hline Moscow & 17 & 19 & 25 & 18 \\
\hline Shanghai & 18 & 21 & 21 & 20 \\
\hline Berlin & 19 & 20 & 16 & 17 \\
\hline Buenos Aires & 20 & 22 & 22 & 33 \\
\hline
\end{tabular}

(Source: 2014 A. T. Kearney Global Cities Index and Emerging Cities Outlook: p. 2) 


\subsubsection{Global Service Firms and Foreign Direct Investment}

Chicago is located in one of the wealthiest regions within the United States (in particular) and the world (in general). The metropolitan area therefore hosts the head offices of more than 400 corporate entities (Moskow and Osborn, 2012: p. 1). For instance, Chicago is the location for the Global Innovation Center of Wrigley, a multinational corporation. Since 2012, the center has been transformed into the headquarters for the corporate entity (Wrigley Company, 2012). Moreover, Chicago serves as a preferred location for the main offices of several Fortune 500 companies. These companies are spread out across various sectors of the economy. In the aerospace and defense sectors for instance, the metropolitan area now serves as the headquarters for Boeing, after the company relocated its main offices here from Seattle in 2001 (World Business Chicago, 2013; Fortune, 2013; Moberg, 2006: p. 32). Also, United Continental Holdings, one of the major players in the airline industry is headquartered in Chicago. Moreover, there are firms in industrial machinery (such as Dover and Illinois Tool Works). The city-region also serves as the location for outfits in the telecommunication sector such as Anixter International, Motorola Solutions, as well as Telephone and Data Systems (World Business Chicago, 2013; Fortune, 2013). In the areas of pharmaceuticals and/or medical services, Chicago hosts firms such as Walgreen and Abbot Laboratories. Moreover, Chicago is the location for Allstate Corporation and Old Republican International, Fortune 500 companies which provide services in property and life insurance (Fortune, 2013; World Business Chicago, 2013). The various Fortune 500 companies make tremendous contributions to Chicago's economy with respect to revenue and employment generation (Table 4.3). 
Table 4.3 Some Fortune 500 Companies in Chicago, 2013

\begin{tabular}{|c|c|c|}
\hline Firm & Industry/Sector & $\begin{array}{l}\text { Revenue (\$ } \\
\text { billions) }\end{array}$ \\
\hline Abbott Laboratories & $\begin{array}{l}\text { Pharmaceuticals and medical } \\
\text { Products }\end{array}$ & 39.9 \\
\hline Allstate & Property and life insurance & 33.3 \\
\hline Anixter International & $\begin{array}{l}\text { Communications and } \\
\text { wire/cable products }\end{array}$ & 6.3 \\
\hline Archer Daniels Midland & Agricultural processing & 89.0 \\
\hline Baxter International & Medical products/services & 14.2 \\
\hline Boeing & Aerospace and defense & 81.7 \\
\hline CDW LLC & $\begin{array}{l}\text { Technology products and } \\
\text { services }\end{array}$ & 10.1 \\
\hline CF Industries Holdings & Agricultural chemicals & 6.1 \\
\hline Discover Financial Services & Credit card services & 9.0 \\
\hline Dover & Industrial machinery & 8.5 \\
\hline Exelon & Electricity supply & 23.5 \\
\hline Hillshire Brands & Food and related services & 9.3 \\
\hline Illinois Tool Works & Industrial machinery & 18.1 \\
\hline Ingredion & Ingredient solutions & 6.5 \\
\hline Kraft Foods Group & Food and related services & 18.3 \\
\hline McDonald's & Food and related services & 27.6 \\
\hline Mondelēz International & Food and related services & 35.0 \\
\hline Motorola Solutions & Communications & 8.7 \\
\hline Navistar International & Vehicle manufacturing & 12.9 \\
\hline OfficeMax & Retailing (Office supplies) & 6.9 \\
\hline Old Republican International & Property Insurance & 5.0 \\
\hline R. R. Donnelley and Sons & Commercial printing & 10.2 \\
\hline Sears Holdings & Department stores & 39.9 \\
\hline Telephone and Data Systems & Wireless telecommunication & 5.3 \\
\hline Tenneco & $\begin{array}{l}\text { Automotive and clean air } \\
\text { products }\end{array}$ & 7.4 \\
\hline United Continental Holdings & Airline & 37.2 \\
\hline United Stationers & Wholesaling (Office products) & 5.1 \\
\hline W. W. Grainger & $\begin{array}{l}\text { Maintenance equipment and } \\
\text { supplies }\end{array}$ & 9.0 \\
\hline Walgreen & Drugstores/pharmaceuticals & 71.6 \\
\hline
\end{tabular}

(Source: World Business Chicago, 2013; Fortune, 2013) 
The role of Chicago as a preferred choice for the main offices of global firms can be explained in part by its strategic location in the United States Midwest. This serves as an attractive destination for businesses which want a more centralized operational base, rather than a location on the East or West Coast. Thus, Chicago is a viable alternative location to other leading global city-regions such as New York and Los Angeles. Besides, the metropolitan area's strategic location makes it a transportation hub in the United States. For instance, Chicago has world-class infrastructure in the form of airports and railways which enhance the operations of businesses. The presence of O'Hare and Midway international airports contribute in making the city-region a center for global economic activity. Moreover, the metropolitan area serves as a railway hub, as it constitutes about half the traffic flow in the whole country (Moskow and Osborn, 2012: p. 15).

Chicago also has a strong workforce, thanks in part to the presence of reputable institutions of higher learning (such as the University of Chicago, Northwestern University, the University of Illinois at Chicago, Loyola University - Chicago, and DePaul University). This workforce provides the kind of skilled labor which these global firms need to operate effectively. Besides, the city-region's reputation as a center of diversity (comprising migrants from different parts of the world) means that even in situations where these firms need semi-skilled or low-skilled labor, there is an ever-ready supply to meet demand. The presence of readily available labor is one of several factors which attract global firms eager to cash in on agglomeration economies.

The presence of Fortune 500 companies has played a vital role in projecting Chicago as a global city-region. These companies enhance the economic stature of the 
metropolitan area as a result of the financial clout associated with their operations. First, the operations of these corporate entities are associated with huge capital injections into the city-regional economy. These inflows help to boost output, employment, and income levels, thereby contributing to economic growth through the multiplier effect (Table 4.3). Moreover, in light of the numerous location choices available to major firms, their choice of Chicago helps to underscore the pre-eminent role the city-region plays in the global economy. For instance, the presence of a global giant such as Boeing serves to enhance the economic status of the metropolitan area. The location of this firm and many others also attract skilled labor which brings its expertise and resources to bear on the development of Chicago. These workers may spend their monies on local goods and services; and this helps to boost the economy of the city-region.

Due to the predominance of global firms in its financial districts, the global era in Chicago has also been characterized by a high level of spatial polarization. Thus, while the downtown area is thriving, poverty levels in the South and West sides continue to increase (Moberg, 1997: p. 73). In the West side for instance, the shutting down of industries such as Sunbeam and Western Electric has led to an upward spiral in poverty and unemployment (Moberg, 1997: p. 73). These factories have ceased to operate in this location as a result of increased competition from rivals in places such as Japan and China. Moreover, the need to cut down on costs has resulted in the outsourcing of operations to facilities in Mexico and Asia (Moberg, 1997: p. 73). Even though some industries can still be found in the West Side, the numbers fall short of what is required to significantly bring down poverty levels in this neighborhood. This problem has been compounded by the influx of migrants, mostly of Mexican origin, who are willing to 
work even for meager wages. In neighborhoods such as Lawndale, it is estimated that about $50 \%$ of adult residents do not have jobs, while $50 \%$ of families are also struggling with poverty (Moberg, 1997: p. 73).

Partly as a result of deindustrialization and spatial inequality, one major attribute of globalization in Chicago has been the growth in corporate services (Sassen, 2004: p. 20). Between 1970 and 1997 for instance, when 300,000 people were laid off due to a decline in manufacturing activity, this was made up for by 600,000 new jobs created in the service sector (Testa, 2004: p. 40). Specifically, the city-region has witnessed a proliferation of firms providing services in areas such as information technology, banking and finance, insurance, law, and advertising. To cite an example, Whittman-Hart, a consulting outfit in the area of information communication technology, witnessed a $68 \%$ rise in its receipts in 1999 as a result of services it provided to big firms. Also, a legal outfit - known as Mayer, Brown, Rowe, and Maw - recorded a 33.3\% increase in revenues just within a decade after the exit of many big firms from the market (Sassen, 2004: p. 20). Another significant feature associated with growth in the service sector of Chicago has been the emergence of a network of actors as a way of pooling synergies. These networks comprise firms in the service industry who share expertise with respect to technology, capital, and labor (Sassen, 2004: p. 21).

Chicago ranks third out of America's largest urban areas when it comes to foreign direct investment. Among these large cities, only New York and Houston surpass the record of Chicago with respect to the level of investment (Table 4.4). Between the years 2003 and 2011 for instance, the mean annual figure for greenfield investment inflows was $\$ 570$ million, with the cumulative total being $\$ 5.12$ billion (Moskow and Osborn, 2012: 
p. 11). As a result of its appreciable economic base, the state of Illinois is the highest recipient of investment inflows within the Midwest of the United States. For instance, as many as 5,800 companies of foreign origin can be found here and these provide jobs to 350,000 people in the state (Demissie, 2006: p. 24). Within the Chicago metropolitan area in particular, companies of foreign origin have generated investments worth billions of dollars and created jobs for over 200,000 residents (Table 4.5).

Table 4.4 Foreign Direct Investments in Eight Large American Cities, 2003-2012

\begin{tabular}{|l|c|c|}
\hline Metropolitan Area & $\begin{array}{l}\text { Total Investment (\$ } \\
\text { billions) }\end{array}$ & Number of Deals Secured \\
\hline New York & 16.34 & 819 \\
\hline Houston & 7.78 & 202 \\
\hline Chicago & $\mathbf{5 . 1 3}$ & $\mathbf{2 0 3}$ \\
\hline Los Angeles & 4.67 & 219 \\
\hline San Francisco & 4.04 & 227 \\
\hline Atlanta & 3.70 & 182 \\
\hline Miami & 2.87 & 165 \\
\hline Dallas & 2.35 & 93 \\
\hline
\end{tabular}

(Source: Moskow and Osborn, 2012: p. 12)

Table 4.5 Employment in Foreign-Owned Firms within America's Large Metropolitan Areas, 2011

\begin{tabular}{|l|c|c|}
\hline Metropolitan Area & $\begin{array}{l}\text { Employment in Foreign- } \\
\text { Owned Firms }\end{array}$ & $\begin{array}{l}\text { Percentage Share of Total } \\
\text { U.S. Employment }\end{array}$ \\
\hline New York & 490,300 & 6.4 \\
\hline Los Angeles & 271,200 & 4 \\
\hline Chicago & $\mathbf{2 2 3 , 5 0 0}$ & $\mathbf{3 . 4}$ \\
\hline Dallas & 134,100 & 2.3 \\
\hline Philadelphia & 137,000 & 2.1 \\
\hline Washington & 126,200 & 2.1 \\
\hline Houston & 178,000 & 2 \\
\hline Boston & 142,800 & 1.9 \\
\hline Atlanta & 134,600 & 1.8 \\
\hline Miami & 91,700 & 1.7 \\
\hline
\end{tabular}

(Source: Saha et al., 2014: p. 14) 
Chicago's appreciable levels of foreign direct investment may be explained primarily by its attractiveness as a global business destination. This situation has been reinforced by the fact that the city has historically had dynamic mayors such as Richard J. Daley, Harold Washington, Richard M. Daley, and Rahm Emanuel who have projected Chicago as a primary location for businesses. For instance Richard J. Daley formed progrowth coalitions with the business community; a situation which won him the trust of the private sector. Also, Harold Washington embarked on a drive to reinvigorate declining neighborhoods by establishing industrial enclaves. Moreover, Richard M. Daley embarked on a program to make Chicago the archetype of a livable city. This led to an influx of multinationals eager to cash in on the city-region's reputation of livability. Currently, Mayor Rahm Emanuel chairs World Business Chicago (a collaborative venture between public and private actors), which seeks to project the city-region as a primary destination for global capital.

Out of the total greenfield foreign direct investment received by Chicago between 2003 and 2011, 83\% of them originated from 10 developed countries (Table 4.6). This development may be explained by investment flows associated with North-North cooperation. Given Chicago's prominence in the United States, it is only natural that it receives appreciable levels of these investments. These investment inflows are widely spread out among a variety of sectors within the city's economy (Table 4.7). For instance, over $\$ 100$ million worth of inflows were recorded by 12 sectors (Moskow and Osborn, 2012: p. 11). This is due to the highly diversified nature of Chicago's economy. 
Table 4.6 Sources of Greenfield Foreign Direct Investment in Chicago, 2003-2011

\begin{tabular}{|c|c|c|c|c|}
\hline $\begin{array}{l}\text { Country of } \\
\text { Origin }\end{array}$ & $\begin{array}{l}\text { Total } \\
\text { Investment } \\
\text { (\$million) }\end{array}$ & $\begin{array}{l}\text { Number of } \\
\text { Deals } \\
\text { Secured } \\
\end{array}$ & $\begin{array}{l}\text { Main } \\
\text { Investors }\end{array}$ & Sector/Industry \\
\hline $\begin{array}{l}\text { United } \\
\text { Kingdom }\end{array}$ & 573 & 48 & $\begin{array}{l}\text { BP, Intertek, } \\
\text { and Miller } \\
\text { Coors }\end{array}$ & $\begin{array}{l}\text { Financial } \\
\text { Services (24) } \\
\text { Business } \\
\text { Services (21) }\end{array}$ \\
\hline Canada & 353 & 14 & Bombardier & $\begin{array}{l}\text { Aerospace (39) } \\
\text { Healthcare (15) }\end{array}$ \\
\hline Japan & 276 & 15 & $\begin{array}{l}\text { Nippon and } \\
\text { Express }\end{array}$ & $\begin{array}{l}\text { Transportation } \\
\text { (29) } \\
\text { Automotive (19) }\end{array}$ \\
\hline Ireland & 268 & 7 & Cognotec & $\begin{array}{l}\text { Information } \\
\text { Technology (70) } \\
\text { Healthcare (19) }\end{array}$ \\
\hline France & 239 & 16 & $\begin{array}{l}\text { Rhodia and } \\
\text { Hermes }\end{array}$ & $\begin{array}{l}\text { Chemicals (24) } \\
\text { Consumer (24) }\end{array}$ \\
\hline Germany & 234 & 18 & BAX Global & $\begin{array}{l}\text { Automotive (23) } \\
\text { Information } \\
\text { Technology (18) }\end{array}$ \\
\hline Australia & 161 & 5 & Servcorp & $\begin{array}{l}\text { Real Estate (89) } \\
\text { Information } \\
\text { Technology (8) }\end{array}$ \\
\hline Italy & 137 & 6 & $\begin{array}{l}\text { Bugari Hotels } \\
\text { and Culti }\end{array}$ & $\begin{array}{l}\text { Hotel (41) } \\
\text { Consumer (20) }\end{array}$ \\
\hline Switzerland & 128 & 9 & $\begin{array}{l}\text { Barry } \\
\text { Callebaut and } \\
\text { Spotme }\end{array}$ & $\begin{array}{l}\text { Food (32) } \\
\text { Communications } \\
\text { (26) }\end{array}$ \\
\hline Sweden & 119 & 11 & $\begin{array}{l}\text { Ikea and Orc } \\
\text { Software }\end{array}$ & $\begin{array}{l}\text { Information } \\
\text { Technology (59) } \\
\text { Consumer (21) }\end{array}$ \\
\hline $\begin{array}{l}\text { Other }(24 \\
\text { countries) }\end{array}$ & 752 & 54 & & \\
\hline
\end{tabular}

(Source: Moskow and Osborn, 2012: p. 13) 
Table 4.7 Sectors for Chicago’s Greenfield Foreign Direct Investment, 2003-2011

\begin{tabular}{|c|c|c|c|}
\hline Sector/Industry & $\begin{array}{l}\text { Total } \\
\text { Investment } \\
\text { (\$ millions) }\end{array}$ & $\begin{array}{l}\text { Percentage of } \\
\text { Investment by BP }\end{array}$ & $\begin{array}{l}\text { Number of Deals } \\
\text { Secured }\end{array}$ \\
\hline $\begin{array}{l}\text { Coal, Oil, and } \\
\text { Natural Gas }\end{array}$ & 84 & 38 & 2 \\
\hline $\begin{array}{l}\text { Software and } \\
\text { Information } \\
\text { Technology }\end{array}$ & 538 & 11 & 43 \\
\hline Finance & 299 & 6 & 23 \\
\hline Business & 239 & 5 & 34 \\
\hline Real Estate & 235 & 5 & 5 \\
\hline Communications & 188 & 4 & 10 \\
\hline $\begin{array}{l}\text { Consumer } \\
\text { Products }\end{array}$ & 168 & 3 & 8 \\
\hline $\begin{array}{l}\text { Hotels and } \\
\text { Tourism }\end{array}$ & 162 & 3 & 4 \\
\hline Aerospace & 138 & 3 & 1 \\
\hline Textiles & 131 & 3 & 9 \\
\hline $\begin{array}{l}\text { Automotive } \\
\text { Components }\end{array}$ & 106 & 2 & 3 \\
\hline Healthcare & 102 & 2 & 2 \\
\hline
\end{tabular}

(Source: Moskow and Osborn, 2012: p. 14)

Foreign direct investment is crucial to the development of Chicago, due in part to the potential for technology transfer by firms which specialize in particular fields such as the communications and information technology sectors. Moreover, investment helps to improve the competitive edge of the city-region as a result of the imperative to create an enabling environment within which businesses can thrive. It also creates new employment opportunities, thereby contributing to enhancing the economic fortunes of the metropolitan area. Ultimately, growth in foreign direct investment, and its concomitants such as the attraction of a skilled workforce from different parts of the world help Chicago to emerge as a diverse and multi-cultural hub of economic activity in the global economy. 


\subsubsection{Public-Private Partnerships and Civic Engagement}

Besides its appreciable levels of foreign direct investment, Chicago also serves as a primary location for organizations which seek to foster relations with the private sector and promote the course of the city-region as a hub for global commerce and politics. For instance, World Business Chicago is a joint venture between public and private actors aimed at creating a favorable environment within which businesses can operate. Specifically, it enhances the competitive edge of Chicago as a global city-region by rolling out business-friendly policies and boosting economic growth. Towards this end, the organization chaired by Mayor Rahm Emanuel has recently been tasked with the design and rolling out of the Chicago Plan for Economic Growth and Jobs. The plan aims at facilitating the expansion of Chicago's economy by making the city-region a primary location for firms in advanced manufacturing and producer services. It also seeks to increase the level of exports generated by the regional economy through improvements in the technical capacity of export firms. Moreover, the plan strives to boost economic growth by upgrading the city's infrastructure to world-class status and training a labor force more in line with the needs of the regional economy. It also seeks to promote tourism, creativity, and entrepreneurship through increased resource injections and training as a way of increasing output and employment (World Business Chicago, 2012).

World Business Chicago is home to ChicagoNEXT, an initiative which enhances the competitive edge of the city-region through science and technology. It also fosters regional growth through innovation and the entrepreneurial bent. The endeavor aims to

pool knowledge capital by attracting skilled professionals to the metropolitan area. It also establishes networks amongst various professionals so that they can coordinate their 
efforts towards bolstering the regional economy. ChicagoNEXT focuses on both start-ups and well-established companies in order to ensure a critical mass with respect to innovation and wealth creation. These encompass firms in areas such as clean technologies, bioscience, and mobile or web technologies (World Business Chicago, 2010 \& 2015). Besides ChicagoNEXT, World Business Chicago also comprises Chicago Sister Cities' International, an organization which fosters international understanding (through cooperation and cultural exchanges) between the Chicago metropolitan area and other regions around the world. This initiative began in 1960 following the establishment of a sister-city relationship with Warsaw, Poland under the influence of Mayor Richard J. Daley. Seven similar partnerships were created with other metropolitan areas during the 1970s and 1980s (Chicago Sister Cities International, 2013). For instance, in June 1989, Mayor Richard M. Daley approved a declaration by the Chicago City Council to formally create a sister-city relationship with Accra, Ghana (Chicago Sister Cities International, 2008). Moreover, following an executive order by Mayor Richard Daley in 1990, many more such relationships have been established (Chicago Sister Cities International, 2013). Currently, Chicago engages in sister-city partnerships with 28 metropolitan regions around the world (Table 4.8). 
Table 4.8 Sister Cities of Chicago

\begin{tabular}{|l|l|}
\hline Region & Chicago Sister Cities \\
\hline North America & Toronto, Canada \\
& Mexico City, Mexico \\
\hline Europe & Paris, France \\
& Birmingham, United Kingdom \\
& Galway, Ireland, \\
& Hamburg, Germany \\
& Gothenburg, Sweden \\
& Lucerne, Switzerland \\
& Milan, Italy \\
& Athens, Greece \\
& Warsaw, Poland \\
& Prague, Czech Republic \\
& Belgrade, Serbia \\
& Kiev, Ukraine, \\
& Vilnius, Lithuania \\
\hline Asia & Shanghai, China \\
& Shenyang, China \\
& Moscow, Russia \\
& Busan, South Korea \\
& Osaka, Japan \\
\hline South America & New Delhi, India \\
\hline Sub-Saharan Africa & Lahore, Pakistan \\
\hline & Accra, Ghana \\
& Durban, South Africa \\
\hline & Casablanca, Morocco \\
& Amman, Jordan \\
& PetahTikva, Israel \\
\hline Bogota, Colombia \\
\hline Middle East
\end{tabular}

(Source: Chicago Sister Cities International, 2013)

Even though the sister-city relationship between Chicago and Accra is largely a symbolic one associated with cultural and educational exchanges, some level of political cooperation (between the two city-regions) has occurred over the years. In 1994 and 1995 for instance, the then mayor of Accra, Nat Nunoo Amartefio, visited Chicago to share experiences with local officials and explore possible areas for investment collaboration. These visits were reciprocated in 1998 and 1999, respectively, by the Accra Committee Chair of Chicago Sister Cities' International, as well as the Black Caucus of the Illinois 
General Assembly Committee (Chicago Sister Cities' International, 2008). In June 2005, Mayor Stanley Nii Adjiri Blankson (of Accra) was invited to Chicago to partake in the United States Conference of Mayors. Also in April 2009, the current mayor of Accra, Alfred Oko Vanderpuye was in Chicago to explore possible areas of collaboration between the two metropolitan areas under the ambit of the Chicago Sister Cities program. Moreover, in May 2010, Ghana's then ambassador to the United States, Daniel Ohene Agyekum, visited Chicago to explore more avenues for collaboration between the cityregion and Ghana. As part of his trip, he met Mayor Richard M. Daley and the Accra Committee of Chicago Sister Cities' International (Chicago Sister Cities' International, 2008).

Besides Chicago Sister Cities' International, The Chicago Council on Global Affairs is another important organization to note when it comes to globalization in the metropolitan area. This organization has the goal of "connecting the world to Chicago and Chicago to the world" (The Chicago Council on Global Affairs, n.d.). Even though it was founded as far back as 1922, the council creates a platform for discussions among stakeholders and policy experts with respect to topical and contemporary issues of global import. It brings together leaders from around the globe and provides a public forum for Chicago's engagement with the rest of the world. Some of the numerous world leaders who have been hosted by the council include: the former Chinese President Jiang Zemin, the former President of Ireland Mary McAleese, as well as the former prime ministers of Australia and Canada, respectively i.e. John Howard and Jean Chretien (The Chicago Council on Global Affairs, n.d.). Issues discussed by this body include the vagaries associated with global economic fortunes, as well as democracy and national soveignty. 
Through its insightful discussions and public engagements, The Chicago Council on Global Affairs shapes public policy, both nationally and globally, and enhances the status of Chicago as a global city-region (The Chicago Council on Global Affairs, n.d.).

The Civic Consulting Alliance, a public-private partnership, is another organization which comes to mind. This grouping emanates from an initiative in 1985 by the then mayor of Chicago, Harold Washington, to improve the financial situation of the city (Civic Consulting Alliance, 2015). As a result, the Civic Committee of the Commercial Club of Chicago (which was mandated by the mayor to carry out an assessment) constituted the Financial Planning Committee bringing together various business actors. In 2005, the Financial Research and Advisory Committee, formed in 1987 to implement the recommendations of the Financial Planning Committee was transformed into the Civic Consulting Alliance (Civic Consulting Alliance, 2015). The alliance pools synergies from both business leaders and public officials towards dealing with some of the region's most pressing challenges in areas such as economic development, education, and health care. It addresses these issues as a way of enhancing the competitive edge of the metropolitan area in the global era (Civic Consulting Alliance, 2015). In the year 2011 for instance, over \$20 million worth of investments in voluntary and non-profit ventures were recorded by various actors in the private sector under the auspices of the Civic Consulting Alliance (Civic Consulting Alliance, n.d.). Moreover, an initiative known as "Choose Chicago" seeks to draw as many as 50 million tourists to the city by the year 2020. A total of $\$ 1.2-\$ 1.3$ billion in proceeds and 155,000-165,000 employment opportunities are expected to be generated in relation to these visitor inflows (Civic Consulting Alliance, 2015). 
Historically, civic engagement in the Chicago metropolitan area has largely proceeded in the absence of formal governmental structures. This occurs primarily because many suburban actors believe that the city of Chicago would unfairly benefit from regional endeavors at the expense of the suburbs (Hamilton, 2002: pp. 70-71). The concern is probably justified as the few regional initiatives which have occurred in the past have been carried out at the behest of Chicago. For instance, the establishment of the Regional Transportation Authority was largely due to the desire by Chicago to source additional funding from the suburbs in order to prevent a collapse of the transportation system in the metropolitan area (Hamilton, 2002: p. 71). Besides, the existence of bodies such as the Northeastern Illinois Planning Commission (NIPC) and the Metropolitan Planning Council (MPC) did not help matters much. For one thing, the NIPC did not have the power of enforcement when it came to dealings with localities; and for another, the MPC did not enjoy much clout amongst business actors even though it was a private entity (Hamilton, 2002: p. 71). In the global era, some positive developments have occurred with respect to regionalism in Chicago. These include the founding of the Metropolitan Mayors' Caucus, as well as the promulgation of Chicago Metropolis 2020. The creation of the mayors' caucus was spearheaded by Mayor Richard J. Daley in part because of insights he gained about the benefits of cooperation during his engagements with other mayors from around the country. Moreover, the private sector was instrumental in the birthing of this grouping. This body has promoted regionalism in Chicago by building partnerships between central city and suburban mayors (Hamilton, 2002: p. 71). Also, Chicago Metropolis 2020 is a private sector initiative spearheaded by The Commercial Club. It brings top business leaders together to campaign on crucial 
public matters. Thus, the body serves to entrench Chicago's long history of private sector involvement in matters of civic engagement (Hamilton, 2002: p. 73).

Regional initiatives in Chicago within the global era also occur in terms of private sector participation as regards the delivery of public services. In the recent past, the private sector has become an important partner in the development of the Chicago cityregion due to resource constraints. Suburban municipalities, in particular, are more prone to privatization as a result of these constraints. Thus, there are efforts to create regional police and fire departments. Moreover, discussions on public-private partnerships are also occurring with respect to infrastructure provision. In the 1980s and 1990s, private-sectorled development became a very attractive option for Chicago in light of financial constraints vis-à-vis the desire by citizens to experience improvements in the quality of service delivery (Johnson, 2005). In response to these pressures, Mayor Richard M. Daley embarked on a program to privatize services such as parking, road surfacing, and tax collection from defaulters. It is estimated that as much as $\$ 56.6$ million was saved by the city as a result of privatization during the period 1989-1995 (Johnson, 2005).

\subsection{Globalization in Accra}

Just like Chicago, Accra has appeared on many rankings of the Globalization and World Cities (GAWC) Index due to its increased engagement with the global economy. For instance, it was ranked as a high-sufficiency city in 2000 and 2008; and a sufficiency city in 2004. In 2010 and 2012, Accra moved up on the GAWC rankings to attain a gamma minus status. The city's ranking in 2010 placed it in the same league as Ottawa, 
Marseilles, Belfast, Orlando, Austin, Milwaukee, and Wellington. And in 2012, this ranking put Accra in the same category as Portland, Columbus (Ohio), Orlando, and Kansas City. This development may be attributable (at least in part) to the commercial production of oil by Ghana, which started during this time period. As a result, there was an influx of new multinational corporations within the oil and gas sector. A few examples of these corporate entities include Tullow Oil Plc and Kosmos Energy Limited. Beside the GAWC index, Accra has been ranked in many other outlets. For instance, in the 2014 MasterCard African Cities Growth Index, it was described as Africa's largest city with the most prospects for "inclusive growth" due to its gains with respect to democratic consolidation and economic policy making. Moreover, the Greater Accra Region came ninth on Ernst and Young's 2014 survey of the 15 most attractive investment destinations on the entire African continent (Table 4.9).

Table 4.9 Rankings of Most Attractive Investment Destinations in Africa

\begin{tabular}{|l|c|}
\hline Locale/Region & Investment Attractiveness Ranking \\
\hline Gauteng, South Africa & 1 \\
\hline Al-Qahirah, Egypt & 2 \\
\hline Casblanca, Morocco & 3 \\
\hline Nairobi, Kenya & 4 \\
\hline Western Cape, South Africa & 5 \\
\hline Lagos State, Nigeria & 6 \\
\hline Luanda, Angola & 7 \\
\hline Tunis, Tunisia & 8 \\
\hline Greater Accra Region, Ghana & 9 \\
\hline Tangier-Tetouan, Morocco & 10 \\
\hline Algiers, Algeria & 11 \\
\hline KwaZulu-Natal, South Africa & 12 \\
\hline Dar es Salaam, Tanzania & 13 \\
\hline Maputo, Mozambique & 14 \\
\hline Eastern Cape, South Africa & 15 \\
\hline
\end{tabular}

(Source: Ernst and Young, 2014) 


\subsubsection{Global Service Firms and Foreign Direct Investment}

Within the global context, Accra serves as a destination of choice for the locations of subsidiaries or local branches of global firms. Many of these firms can be found within the Ghana Club 100 group. The Ghana Club 100 concept was introduced in 1998 by the Ghana Investment Promotion Center (the main body in charge of registering and promoting new investment projects in Ghana). It aims to extol the contributions of the nation's foremost 100 companies in any particular year towards the promotion of excellence in the corporate world. In 2012 for instance, the three corporate entities which raked in the highest profit levels were located in Accra. At least two of these companies (namely British American Tobacco Ghana Limited and G4S Security Services Ghana Limited) were multinational corporate entities. British American Tobacco Ghana Limited is the local branch of British American Tobacco Plc, a multinational corporation headquartered in London. G4S Security Services Ghana Limited is a subsidiary of G4S Plc, which is headquartered in Crawley, the United Kingdom. The three biggest companies within the Ghana Club 100 group (namely Goldfields Ghana Limited, Newmont Ghana Gold, and Scancom) were all multinational in nature and had at least an office in Accra. Goldfields Ghana Limited is a subsidiary of Goldfields Limited, a multinational corporation headquartered in Johannesburg, South Africa (with operations in South Africa, Ghana, Peru, and Australia). Newmont Ghana Limited is a local branch of Newmont Mining Corporation, a multinational group with operations in the United States, Mexico, New Zealand, Australia, Peru, and Ghana. The global headquarters for this group can be found in Denver, Colorado. Scancom Ghana Limited is a subsidiary of South African telecommunication giant MTN which is headquartered in Johannesburg. 
Moreover, even new corporate entities in the Ghanaian market (such as Multipro Private Company which placed within the first 10 companies, and was the highest ranked among the new entrants), were located in Greater Accra Metropolitan Area. Multipro Private Company is a subsidiary of the Tolaram group, whose head office is in Lagos, Nigeria.

The increased prominence of global firms in Accra may be accounted for by several factors. First, the city's relatively centralized location in West Africa makes it an attractive alternative business destination i.e. in relation to other metropolises such as Dakar and Lagos, located in the west and east, respectively. Besides, its location along Ghana's coast, close to the port of Tema, serves as a major source of attraction. The cityregion's "situation" near the point where the Equator meets the Prime Meridian literally places it at the geographic center of the Earth. This has earned it the accolade "gateway to West Africa."

Moreover, Accra's status as both an administrative and commercial capital places it ahead of other Ghanaian metropolitan areas when it comes to competing for global capital. Specifically, its relatively good infrastructure compared to other Ghanaian towns and cities makes it a viable location for investors. These include roads, highways, and the Kotoka International Airport. Accra has also got a pool of labor (both skilled and unskilled) which global firms can easily draw on. The aforementioned factors, coupled with the existence of other firms with knowledge and expertise, are the building blocks for agglomeration economies in the city-region.

The aforementioned developments notwithstanding, Accra's attraction of subsidiaries or local branches of global firms (rather than headquarter locations) may be 
explained by its relatively recent engagement with the private sector. Prior to the $1980 \mathrm{~s}$, economic development in the metropolitan area was almost entirely driven by the public sector, a tradition inherited from the days of British colonial rule and continued after independence. As a result, the private sector's growth was severely hampered. It was only from the 1980s onwards that Ghana began to open its doors to global capital due to liberal economic reforms rolled out with the backing of the International Monetary Fund and the World Bank. As a result of its relatively recent engagement with the private sector, Accra may be considered as a globalizing, rather than a full-fledged global cityregion.

Even though it primarily serves as a location for subsidiaries or local branches of global firms, Accra is also emerging as a headquarter location for budding multinationals, especially within the West African sub-region. Many of these companies can be found in the Ghana Club 100 group. In 2012 for instance, all the three fastest growing corporate entities within the Ghana Club 100 group were located in Accra, with two of these (namely McDan Shipping Company and RLG Communications), being multinational in nature. McDan Shipping Company has its head office in Accra and other offices in Sierra Leone and Liberia. RLG Communications also has its headquarters in Accra, with branches in Nigeria, Gambia, South Africa, China, and Dubai. Moreover, Databank Financial Services, a group comprising services in brokerage, asset management, corporate finance, and research, has got its headquarters in Accra. This multinational group has branches in Liberia and Sierra Leone. Established in 1990, Databank was a pioneer in developing the concept of investment banking in Ghana. The company has also been a trailblazer in the emergence of Ghana's capital markets, spearheading the 
rolling out of the nation's premier stock market index (Databank Financial Services, 2013-2014).

The gradual emergence of Accra as a headquarter location for budding multinationals demonstrates the potential rise of the city-region as a global economic powerhouse in the future. Moreover, it exhibits the changing nature of the corporate geographies associated with the operation of multinationals in the global era. The role of Accra as a headquarter location for these emerging multinationals may be explained by the increasingly important role private capital plays in the city-region's development. As a result, the entrepreneurial spirit is catching up with many Ghanaians, especially recent return migrants who wish to bring their acquired knowledge and expertise to bear on the development of the nation. For instance, Databank Financial Services was co-founded by Ken Ofori-Atta and Keli Gadzekpo, two Ghanaian return migrants with some foreignacquired training.

The global era in Accra has also been associated with a phenomenal growth in the service sector of the economy. This has occurred primarily because, many of the foreignowned firms operating in the city-region engage in activities such as banking and finance, insurance, consulting, and advertising. For instance, $16 \%$ of foreign-owned corporate entities attracted into Accra since the 1980s have been involved in the financial sector, while only $9 \%$ of indigenous firms can be found in this industry (Grant and Nijman, 2002: p. 327). Many of the service firms found in the metropolitan area appear to be burgeoning and not large in their scale of operations due to Accra's relatively nascent stage of global engagement. Thus, the largest and most well-established firms tend to be those with a relatively long history of operating in the city-region (Grant and Nijman, 
2002: p. 331). Accra's service firms appear to value the importance of agglomeration economies as they seek to locate close to each other. However, whether or not they are able to do so depends on the land market. In areas such as Osu and Cantonments, a high level of market speculation, coupled with the interplay between demand and supply forces tend to guide the purchase and sale of land. Thus, land appears to be pricier here than in many other parts of the metropolitan area. These make them more attractive to foreign companies with relatively high capital outlays (Grant and Nijman, 2002: p. 331).

The service sector constitutes an important pillar which entrenches the role of Accra in the global economy. This occurs partly because at least some of the most prominent service firms are hived off branches of multinational corporations. Examples include SG-SSB and KPMG. Also, liberalization of the banking sector over the years has resulted in a phenomenal growth in both indigenous and foreign banks, thereby enhancing the role of Accra as a destination of choice for private capital. The service sector creates jobs and wealth, ultimately helping to further Ghana's goals of poverty reduction and the creation of opportunities for all. Moreover, due to Accra's relatively low industrial base compared to the port city of Tema, the service sector largely constitutes the lifeblood of its economy. Even though Accra has never been a manufacturing hub per se, growth in the service sector still marks a new phase in the city's development as it indicates the vital role of private capital. Also, privatizations of some erstwhile state-owned banks have led to increased foreign capital inflows, thereby enhancing the city-region's linkages with the global economy. Moreover, growth in the service sector was pivotal in reviving the economic fortunes of Ghana after the economic decline witnessed in the 1970s and 1980s. 
One important development associated with globalization in Accra is spatial polarization within the internal geography of the city-region (Grant and Nijman, 2004: p. 474). This occurs partly due to the concentrations of global firms in central business districts, to the virtual exclusion of other parts of the metropolitan area. Moreover, increased infrastructural and other investments by government in such areas, at the expense of others, account for this situation. Within the Greater Accra Metropolitan Area overall, much economic activity appears to be concentrated along the Accra-Tema development corridor, which is the most urbanized part of the city-region. For instance, these areas boast of infrastructural and other facilities such as good road networks, the Kotoka International Airport, and the Port of Tema (Grant and Nijman, 2004: p. 474). In the peri-urban parts of the metropolitan area however, poverty levels appear to have been either maintained or heightened. To cite an example, suburbs such as Chorkor, Mamobi, and Nima continue to experience relatively high levels of poverty and deteriorating infrastructure, while areas such as East Legon, Roman Ridge, Osu, and Cantonments boast of a growing population of middle and upper class residents, as well as a good network of roads and other infrastructure (Grant and Nijman, 2004: pp. 474-477).

Perhaps, the single most important development associated with globalization in Accra has been the phenomenal growth in the levels of foreign direct investment in the recent past. This has occurred primarily because of vigorous government campaigns over the years to attract investment. According to the Ghana Investment Promotion Center (2001), as much as $86 \%$ of Ghana's foreign direct investment inflows is concentrated in the Greater Accra Metropolitan Area. Evidence points to the fact that since the advent of the global era, there has been a continuous increase in the levels of foreign direct 
investment in Accra, with a concomitant decline in investment flows to other regions in the country (Grant and Nijman, 2004: p. 474). Between the 1970s and 1999 for instance, the level of investment flows to Kumasi, Ghana's second largest city, decreased from $18 \%$ to $9 \%$ (Grant and Nijman, 2004: p. 474). Out of the total number of registered investment projects in Ghana between 1994 and 2009, as much as 82.05\% were concentrated in the Greater Accra Region alone. Table 4.10 summarizes regional investment information for major sectors of the economy: manufacturing (MN), service (SV), tourism (TS), building and construction (BC), export trade (ET), agriculture (AG), and general trade (GT).

The dominance of Accra when it comes to foreign direct investment inflows can be explained by its status as Ghana's primate city. Thus, it constitutes the engine of the nation's economy. This prominence has been reinforced through increased infrastructural and other investments by successive governments in the metropolitan area with the goal of making it a national and regional economic hub. Foreign direct investment creates jobs and wealth, which contribute appreciably towards enhancing the economic fortunes of the city-region. Moreover, investment is an essential pillar of private sector engagement in city-regional development. This is because global firms usually bring both financial resources and technical expertise on board; and these serve to enhance the competitive edge of the metropolitan area. 
Table 4.10 Regional Breakdown of Registered Projects and Investments: September 1994 to December 2009

\begin{tabular}{|c|c|c|c|c|c|c|c|c|}
\hline \multicolumn{9}{|c|}{ Sectors } \\
\hline Region & $\begin{array}{l}\text { Number } \\
\text { of } \\
\text { Projects }\end{array}$ & MN & SV & TS & BC & ET & AG & GT \\
\hline $\begin{array}{l}\text { Greater } \\
\text { Accra }\end{array}$ & $\begin{array}{l}2,637 \\
(82.05 \%)\end{array}$ & 686 & 720 & 232 & 211 & 116 & 83 & 427 \\
\hline Ashanti & $\begin{array}{l}185 \\
(5.76 \%)\end{array}$ & 54 & 40 & 21 & 13 & 17 & 11 & 20 \\
\hline Western & $\begin{array}{l}124 \\
(3.86 \%)\end{array}$ & 22 & 40 & 24 & 9 & 9 & 7 & 5 \\
\hline Central & $\begin{array}{l}81 \\
(2.52 \%)\end{array}$ & 20 & 7 & 24 & 6 & 2 & 22 & 0 \\
\hline Eastern & $\begin{array}{l}79 \\
(2.46 \%)\end{array}$ & 13 & 12 & 9 & 3 & 2 & 39 & 0 \\
\hline Volta & $\begin{array}{l}43 \\
(1.34 \%)\end{array}$ & 11 & 3 & 2 & 1 & 2 & 23 & 1 \\
\hline Northern & $\begin{array}{l}30 \\
(0.93 \%)\end{array}$ & 5 & 4 & 6 & 2 & 2 & 8 & 2 \\
\hline $\begin{array}{l}\text { Brong- } \\
\text { Ahafo }\end{array}$ & $\begin{array}{l}26 \\
(0.81 \%)\end{array}$ & 8 & 2 & 1 & 2 & 8 & 5 & 0 \\
\hline $\begin{array}{l}\text { Upper } \\
\text { East }\end{array}$ & $\begin{array}{l}7 \\
(0.22 \%)\end{array}$ & 1 & 3 & 1 & 1 & 1 & 0 & 0 \\
\hline $\begin{array}{l}\text { Upper } \\
\text { West }\end{array}$ & $\begin{array}{l}2 \\
(0.06 \%)\end{array}$ & 0 & 0 & 1 & 1 & 0 & 0 & 0 \\
\hline Total & $\begin{array}{l}3,214 \\
(100 \%)\end{array}$ & & & & & & & \\
\hline
\end{tabular}

(Source: The GIPC Quarterly Report, December 2009: p. 5)

From 1994 to 2000, a total of 1,084 projects were recorded by the Ghana Investment Promotion Center (GIPC). These projects had a total capitalization of US\$1,608.52 million. The service sector, which had the biggest number of registered projects (i.e. 314) also recorded the highest total investment of US\$886.7 million. This was followed by the manufacturing sector, with 300 projects and a total investment of US\$319.82 million (Table 4.11). Between the years 2001 and 2007, a total of 1,149 
projects (excluding those registered by liaison offices around the country), with a total capitalization of US $\$ 3,072.91$ million, were recorded by the GIPC. The manufacturing sector accounted for the bulk of these projects (i.e. 335) and investments (i.e.

US $\$ 2,288.81$ million). This was followed by the service sector, which recorded 306 projects and a total investment of US\$298 million (Table 4.11). Out of Ghana's overall level of foreign direct investment between 1994 and 2009, the manufacturing sector received US $\$ 7.242$ billion, representing $55.12 \%$ of the total. This was followed by building and construction with US\$2.25 billion (17.13\% of total), the service sector with US\$1.208 billion (9.19\% of the total), and general trade with US\$981.90 million (7.5\% of the total).

Table 4.11 Registered Projects and Investments in Ghana: 1994-2007

\begin{tabular}{|l|l|l|l|}
\hline Time Period & Sector & $\begin{array}{l}\text { Number of } \\
\text { Registered } \\
\text { Projects }\end{array}$ & $\begin{array}{l}\text { Total Investment } \\
\text { (US\$ million) }\end{array}$ \\
\hline \multirow{4}{*}{$\begin{array}{l}\text { September 1994 to } \\
\text { December, 2000 }\end{array}$} & Manufacturing & 300 & 319.82 \\
\cline { 2 - 4 } & Service & 314 & 886.70 \\
\cline { 2 - 4 } & Tourism & 129 & 25.19 \\
\cline { 2 - 4 } & $\begin{array}{l}\text { Building and } \\
\text { Construction }\end{array}$ & 92 & 111.67 \\
\cline { 2 - 4 } & Export Trade & 82 & 10.89 \\
\cline { 2 - 4 } & Agriculture & 87 & 177.14 \\
\cline { 2 - 4 } January 2001 to March, & General Trade & 80 & 77.11 \\
\cline { 2 - 4 } & Total & 1,084 & $1,608.52$ \\
\cline { 2 - 4 } & Manufacturing & 335 & $2,288.81$ \\
\cline { 2 - 4 } & Service & 306 & 298.86 \\
\cline { 2 - 4 } & Tourism & 122 & 75.09 \\
\cline { 2 - 4 } & $\begin{array}{l}\text { Building and } \\
\text { Construction }\end{array}$ & 84 & 197.63 \\
\cline { 2 - 4 } & Export Trade & 45 & 19.56 \\
\cline { 2 - 4 } & Agriculture & 68 & 63.42 \\
\cline { 2 - 4 } & General Trade & 189 & 129.55 \\
\cline { 2 - 4 } & Total & 1,149 & $3,072.91$ \\
\hline
\end{tabular}

(Source: The GIPC Quarterly Report, April 2007: p. 5) 
Accra's appreciable levels of investment in the recent past may be explained in light of vigorous campaigns by successive governments to promote foreign direct investment. As part of this drive, the nation has rolled out attractive packages for potential investors. For instance, these laws give prospective investors a wide range of options comprising: $100 \%$ ownership by Ghanaians, joint ventures between indigenous Ghanaians and foreigners, as well as full ownership by foreign investors.

Between September 1994 and December 2009, Ghana received foreign direct investments from nations in different parts of the world: Asia, the Middle East, Europe, North America, and Africa. China was the largest investor in terms of the number of projects recorded for this period (i.e. 415). This was followed by India (with 388 projects) and Lebanon (with 291 projects). The United Kingdom and the United States were the fourth and fifth largest investors, with 267 and 177 registered projects, respectively. The service sector recorded the highest number of 831 projects. This was followed by manufacturing (with 820 projects), general trade ( 456 projects), as well as building and construction (249 projects). As regards the level of capital inflows associated with foreign direct investment in Ghana, the highest figure of US $\$ 4.833$ billion was recorded by the United Kingdom. This was followed by the United States and United Arab Emirates, respectively, with capital injections of US\$2.462 billion and US $\$ 2.059$ billion. Nigeria and Malaysia also invested US\$1.174 billion and US\$289.22 million respectively in Ghana during this time period. China and India, which recorded the largest and second largest number of projects respectively, came sixth and eighth in terms of the level of capital injections associated with foreign direct investment. Tables 4.12 and 4.13 summarize investment information for 20 leading countries in major 
sectors of the economy: manufacturing (MN), service (SV), tourism (TS), building and construction (BC), export trade (ET), agriculture (AG), general trade (GT), and liaison (LS).

Table 4.12 Registered Investment Projects in Ghana by Country of Origin: September 1994 to December 2009

\begin{tabular}{|l|l|l|l|l|l|l|l|l|l|}
\hline & & \multicolumn{3}{|c|}{ Sectors } & & & & & \\
\hline Country & $\begin{array}{l}\text { Num. } \\
\text { of } \\
\text { Projs. }\end{array}$ & MN & SV & TS & BC & ET & AG & GT & LS \\
\hline China & 415 & 145 & 66 & 59 & 20 & 7 & 8 & 103 & 7 \\
\hline India & 388 & 129 & 45 & 19 & 15 & 53 & 26 & 73 & 28 \\
\hline Lebanon & 291 & 103 & 33 & 33 & 35 & 6 & 9 & 71 & 1 \\
\hline $\begin{array}{l}\text { United } \\
\text { Kingdom }\end{array}$ & 267 & 50 & 104 & 23 & 25 & 9 & 10 & 21 & 25 \\
\hline $\begin{array}{l}\text { United } \\
\text { States }\end{array}$ & 177 & 26 & 76 & 30 & 12 & 4 & 17 & 4 & 8 \\
\hline Nigeria & 131 & 19 & 60 & 5 & 16 & 4 & 2 & 18 & 7 \\
\hline Germany & 130 & 29 & 49 & 15 & 9 & 4 & 14 & 3 & 7 \\
\hline $\begin{array}{l}\text { Nether- } \\
\text { lands }\end{array}$ & 96 & 10 & 39 & 10 & 4 & 11 & 14 & 4 & 4 \\
\hline $\begin{array}{l}\text { South } \\
\text { Korea }\end{array}$ & 90 & 23 & 23 & 12 & 5 & 1 & 16 & 7 & 3 \\
\hline Italy & 85 & 36 & 6 & 9 & 18 & 8 & 2 & 4 & 2 \\
\hline France & 71 & 16 & 21 & 15 & 2 & 3 & 5 & 4 & 5 \\
\hline $\begin{array}{l}\text { Switzer- } \\
\text { land }\end{array}$ & 57 & 11 & 15 & 3 & 5 & 4 & 6 & 5 & 8 \\
\hline $\begin{array}{l}\text { South } \\
\text { Africa }\end{array}$ & 53 & 4 & 34 & 1 & 3 & 0 & 1 & 5 & 5 \\
\hline Canada & 52 & 11 & 17 & 4 & 10 & 1 & 4 & 4 & 1 \\
\hline Denmark & 36 & 8 & 14 & 1 & 1 & 1 & 4 & 1 & 6 \\
\hline Belgium & 34 & 2 & 9 & 4 & 3 & 4 & 6 & 4 & 2 \\
\hline Australia & 31 & 7 & 13 & 6 & 1 & 1 & 1 & 0 & 2 \\
\hline $\begin{array}{l}\text { British } \\
\text { Virgin } \\
\text { Islands }\end{array}$ & 30 & 3 & 17 & 2 & 2 & 0 & 2 & 2 & 2 \\
\hline Spain & 24 & 9 & 3 & 1 & 5 & 1 & 3 & 2 & 0 \\
\hline Taiwan & 22 & 9 & 3 & 1 & 0 & 1 & 2 & 6 & 0 \\
\hline Others & 734 & 170 & 184 & 68 & 58 & 36 & 46 & 115 & 57 \\
\hline Total & 3,214 & 820 & 831 & 321 & 249 & 159 & 198 & 456 & 180 \\
\hline Source & & & & & & & & & \\
\hline
\end{tabular}

(Source: The GIPC Quarterly Report, December 2009: p. 8) 
Table 4.13 Foreign Direct Investment in Ghana by Country of Origin: September 1994 to December 2009 (Approximate Values)

\begin{tabular}{|c|c|c|c|c|c|c|c|c|c|c|}
\hline & & & \multicolumn{8}{|c|}{ Level of FDI for various sectors (US\$ million) } \\
\hline Country & $\begin{array}{l}\text { Num. } \\
\text { Of } \\
\text { Projs }\end{array}$ & $\begin{array}{l}\text { Level } \\
\text { of FDI } \\
\text { (\$mil) }\end{array}$ & MN & SV & TS & BC & ET & $\mathbf{A G}$ & GT & $\mathbf{L S}$ \\
\hline $\begin{array}{l}\text { United } \\
\text { Kingdom }\end{array}$ & 267 & 4,833 & 4,663 & 66 & 5.8 & 77 & 2.5 & 6.4 & 12 & 0 \\
\hline $\begin{array}{l}\text { United } \\
\text { States }\end{array}$ & 177 & 2,462 & 2,225 & 139 & 15 & 28 & 0.6 & 49 & 3.2 & 2.5 \\
\hline $\begin{array}{l}\text { United } \\
\text { Arab } \\
\text { Emirates }\end{array}$ & 8 & 2,059 & 0 & 0.95 & 0 & 2,057 & 0 & 0 & 1 & 0.12 \\
\hline Nigeria & 131 & 1,174 & 7.8 & 351 & 3.2 & 15.7 & 0.1 & $\begin{array}{l}0.0 \\
3\end{array}$ & 796 & 0.01 \\
\hline Malaysia & 15 & 289 & 4.6 & 284 & 0 & 0.3 & 0 & 0 & 0.6 & 0.08 \\
\hline China & 415 & 255 & 165 & 17 & 6.5 & 7.3 & 0.9 & 4.9 & 54 & 0.05 \\
\hline $\begin{array}{l}\text { South } \\
\text { Africa }\end{array}$ & 53 & 150 & 3 & 43 & 1.5 & 2.1 & 0 & 92 & 9 & 0 \\
\hline India & 388 & 144 & 29 & 16 & 0.9 & 7.4 & 9.2 & 47 & 35 & 0 \\
\hline $\begin{array}{l}\text { Malaysia } \\
\text { /Ghana }\end{array}$ & 1 & 118 & 0 & 118 & 0 & 0 & 0 & 0 & 0 & 0 \\
\hline Italy & 85 & 115 & 72 & 0.86 & 2.3 & 37.3 & 1.3 & $\begin{array}{l}0.0 \\
9\end{array}$ & 1.8 & 0 \\
\hline $\begin{array}{l}\text { Switzer- } \\
\text { land }\end{array}$ & 57 & 102 & 26 & 16 & 4.2 & 1.3 & 4.2 & 46 & 3.4 & 0.70 \\
\hline Lebanon & 291 & 95 & 26 & 3.2 & 6 & 10.3 & 0.3 & 0.8 & 48 & 0 \\
\hline $\begin{array}{l}\text { British } \\
\text { Virgin } \\
\text { Islands }\end{array}$ & 30 & 94 & 8.8 & 28 & 44 & 5.6 & 0 & 1.9 & 4.8 & 0 \\
\hline France & 71 & 79 & 10 & 7 & 1.3 & 0.9 & 0.6 & 50 & 1.2 & 6.9 \\
\hline Ireland & 6 & 70 & 0 & 70 & 0.2 & 0.1 & 0 & 0 & 0 & 0 \\
\hline Mauritius & 12 & 63 & 1.9 & 49 & 0 & 0 & 0 & 0 & 12 & 0 \\
\hline $\begin{array}{l}\text { Nether- } \\
\text { lands }\end{array}$ & 96 & 62 & 6.8 & 25 & 2.9 & 9.3 & 3.8 & 8.7 & 4.3 & 0 \\
\hline $\begin{array}{l}\text { South } \\
\text { Korea } \\
\end{array}$ & 90 & 56 & 8.7 & 21 & 1.3 & 6.9 & 0.03 & 14 & 3.4 & 0 \\
\hline Singapore & 17 & 49 & 43.4 & 1.5 & $\begin{array}{l}0.0 \\
8\end{array}$ & 0 & 2.2 & 0.3 & 1.2 & 0 \\
\hline Denmark & 36 & 42 & 11 & 6.2 & $\begin{array}{l}0.0 \\
8\end{array}$ & 1.1 & 0.08 & 23 & 0.5 & 0 \\
\hline Others & 968 & 827 & 237 & 222 & 39 & 164 & 11.2 & 38 & 113 & 0.49 \\
\hline Total & 3214 & 13,139 & 7,242 & 1,208 & 92 & 2,251 & 20 & 298 & 982 & 10 \\
\hline
\end{tabular}

(Source: The GIPC Quarterly Report, December 2009: p. 9) 
Accra's attraction of foreign direct investment from nations in both the Global North and South may be explained by North-South and South-South cooperation. These international collaborative platforms usually have an investment component; and Accra has benefitted immensely from this, given its status as a capital city-region. With respect to South-South cooperation in particular, the prominent roles of China and India are worthy of note. These two rising powerhouses, by virtue of their investments, seek to cement their engagement with the African continent and rest of the global economy.

\subsubsection{Institutional Restructuring and Public-Private Partnerships}

Politically, the nature of globalization in Accra may largely be understood with respect to administrative or institutional restructuring. This is due to the relative prominence of the public sector in the development of the city-region. Historically, the

public sector in Ghana has been confronted with challenges such as bureaucracy and low levels of technical capacity. Towards dealing with these and other problems, the Government of Ghana, under the auspices of the Bretton Woods Institutions, embarked on various initiatives, especially in the 1980s and 1990s, to restructure the civil service (Haruna, 2004: p. 191). First, there was a pruning down of the workforce in the public sector as a way of cutting down on waste and inefficiency. For instance, during the period 1986-1993, over 44,000 workers were laid off (Haruna, 2004: p. 191). In addition, institutional restructuring led to the administrative decentralization of various government "ministries, departments, and agencies" (Haruna, 2004: p. 192). Moreover, public sector reform entailed the provision of managerial training as a way of enhancing 
the technical capacity of the remaining workforce (Haruna, 2004: pp. 191-192). There was also a shift in focus towards performance assessment underpinned by clearly-defined goals and objectives, as well as participatory and feedback mechanisms (Haruna, 2004: p. 192).

As regards performance management, restructuring resulted in an increased focus on strategic planning at various governmental layers. The goal was to ensure that all the various agencies effectively pooled their efforts towards attaining overarching national development goals. The reforms occurred on both institutional and individual bases, largely under the supervision of the Office of the Head of Civil Service (Ohemeng, 2010: p. 465). Institutionally, restructuring stressed the need for an emphasis on organizational outputs through more efficient and customer-based mechanisms. These reforms were focused on organizations at the ministerial level which belong in the civil service due to their important roles in the coordination of central government activities (Ohemeng, 2010: p. 465). The restructuring also comprised local government entities such as regional coordinating councils, as well as metropolitan, municipal, and district assemblies. They were aimed at enhancing administrative efficiency through the transfer of relevant central government functions to regional and local bodies. As regards the individual, there was a shift in focus towards enhancing the capacity of organizational managers as a way of empowering them to contribute effectively in attaining central government goals (Ohemeng, 2010: p. 465).

The administrative nature of political globalization in Ghana is also evident in the creation of metropolitan, municipal and district assemblies, as well as the allocation of a minimum of 5\% of total government revenue to these assemblies (Haruna, 2004: p. 193). 
During the first twenty years of its implementation, some notable achievements chalked in Ghana's local government reform (launched in1988) included the establishment of 170 local governmental units nationwide. Moreover, it served as a platform for political empowerment of citizens and sought to promote the quality of local infrastructure through the District Assemblies Common Fund (Government of Ghana - Ministry of Local Government and Rural Development, 2010: p. 8). It also enhanced cooperation between local governments on the one hand and development agencies on the other hand. These achievements notwithstanding, some challenges could be observed. Among these were low levels of citizen engagement, poor coordination of decentralized local governmental units and agencies, as well as a relatively low emphasis on the region as a defining framework for pursuing national development (Government of Ghana - Ministry of Local Government and Rural Development, 2010: p. 8). Moreover the non-partisan nature of elections at the local level, coupled with the strong role played by the central government in the operations of local authorities, meant that the devolution of power was largely administrative in nature (Mohan, 1996: pp. 88-89).

Institutional restructuring in Accra also occurs in terms of public-private partnerships aimed at improving upon the quality of public service delivery. As regards urban water supply for instance, the Government of Ghana under the auspices of the Bretton Woods Institutions embarked on a program to separate the administration of water supply in rural communities and small towns from those in urban areas (Fuest and Haffner, 2007; p. 173). Part of this strategy involved the hiving off of responsibilities for rural and small town water supply from the mainstream Ghana Water and Sewage Corporation (GWSC) to the newly created department known as the Community Water 
and Sanitation Division in 1994 (Fuest and Haffner, 2007; p. 173). Moreover, the strategy sought to privatize the management of urban water supply with the objective of courting more capital injections, enhancing administrative efficiency, and improving upon the quality of service delivery. In 1999, an Act of Parliament resulted in the separation of the Community Water and Sanitation Division from the GWSC (Fuest and Haffner, 2007; p. 174). Moreover, the GWSC was transformed into the Ghana Water Company Limited, a limited liability company. Overall, urban water supply in the recent past may be perceived within the lens of public-private partnerships where the private sector manages water facilities or performs other specific tasks, while the public sector owns the assets responsible for water supply (Fuest and Haffner, 2007; p. 174).

Besides institutional restructuring, political globalization also occurs in the form of strategic partnerships between metropolitan, municipal, and districts assemblies on the one hand and various development partners (local and international) on the other hand. These partnerships deal with pressing challenges such as high levels of poverty, economic inequality, and unemployment which confront the metropolitan area. In 2010 for instance, the Accra Metropolitan Assembly or AMA entered into a collaborative venture with the Millennium Cities Initiative of Columbia University's Earth Institute (Millennium Cities Initiative, n.d.). This collective action involved several other partners such as non-profit organizations, community-based and civil society groups, as well as international development agencies. Through field evaluations, GIS techniques, citizen engagement, and "scenario planning," the Millennium Cities Initiative is helping the AMA to improve upon its planning and development processes. Moreover, there is an emphasis on community and economic development, as well as environmental 
management, with the goal of improving upon the quality of life of city residents (Millennium Cities Initiative, n.d.). Overall, the main aim of the Millennium Cities Initiative was to help the city realize the Millennium Development Goals and other interventions deemed to be of priority by beneficiary communities (Millennium Cities Initiative, n.d.). The Millennium Development Goals, defined by the United Nations in 2000 , include ambitious targets such as reducing the level of world poverty by half and providing free, basic education by 2015 (United Nations, n.d.).

\subsection{Discussion}

The various observations on globalization in Chicago and Accra may be explained by the unique local factors present in the two city-regions. With specific reference to Chicago, the evolution of the metropolitan area in the global era may be attributed (at least in part) to the emergence of pro-growth coalitions comprising mayors, other local officials, and various elements in the business community. These coalitions have been instrumental in the transformation of the Loop into a major hub for service firms within sectors such as banking and finance. For instance, they play pivotal roles in causing the relocation of central city manufacturing firms and poor residents to the suburbs as a way of promoting gentrification and commercial activity (Rast, 1999: p. 26).

As of the time Richard J. Daley took office as mayor in 1955, Chicago was on a downward slide, having recorded over 53,000 job losses in the manufacturing sector within the period 1947-1953 (Rast, 1999: p. 26). Towards stemming the tide of decline, Daley sought to form a strategic partnership with the city's private sector. Initially, his attempts were met with skepticism due to incidents of graft and poor visioning associated 
with some of his predecessors. Thus, in order to build trust, Daley appointed technocrats to fill important administrative and cabinet portfolios (Rast, 1999: p. 27). In 1957, Mayor Daley created the Department of City Planning to oversee his vision for the reinvigoration of the city's downtown area. The generous budgetary allocation to this initiative, coupled with its tremendous accomplishments such as the putting up of many new office complexes in the Loop won Daley the admiration of the business community. This helped him to strengthen his pro-growth coalition (Rast, 1999: p. 27).

The fact that Daley was both Chicago mayor and chairman of the Democratic Central Committee within Cook County helped to strengthen his political influence, thereby giving him the leverage to achieve his vision for the city (Rast, 1999: pp. 27-28). During his tenure in office, Mayor Daley largely shied away from the creation of institutions to promote the course of regional development (unless it was absolutely required). Instead, he relied on informal networks amongst various actors, with him playing a supervisory role. The goal was to strengthen his powers and reduce the bureaucracy which sometimes comes with the establishment of formal institutions. Part of Daley's strategy involved the creation of various committees to advise him on relevant issues (Ferman, 1996: p. 60). For instance, planning within the economic and cultural realms was carried out by the Mayor's Committee for Economic and Cultural Development. This body continued to operate as a committee for the whole of Daley's tenure in spite of recommendations from its head for it to be turned into a formal institution (Ferman, 1996: p. 60). Even in situations where the mayor created institutions, functions were spread out among different bodies as a way of avoiding centralization and bureaucracy. For example, the creation of the Department of City Planning 
notwithstanding, certain aspects of downtown renewal such as zoning were carried out by other entities (Ferman, 1996: p. 60).

By the early part of the 1970s, Mayor Richard J. Daley's pro-growth strategy appeared to have run its full course. At this point in time, there were tremendous decreases in the number of people engaged in manufacturing, with estimates of about 150,000 jobs being lost during the period. Moreover, there was a legal threat to the Shakman Decree of 1972 which had outlawed the sacking of political appointees. The Daley machine appeared to be crumbling as opposition to patronage jobs began to grow, particularly among the city’s African-American community (Longworth, 2004: p. 72). Thus, following Daley's death in 1976, his successor Michael Bilandic was defeated in the mayoral elections of 1979 by Jane Byrne (Longworth, 2004: pp. 72-73). Unfortunately, Byrne's mayoral reign coincided with Chicago's economic decline, a situation partly attributable to damage the city suffered during severe winter snow storms in 1979 (Bennett, 2006: p. 46). As a result of the city's economic challenges, the AfricanAmerican population which played a pivotal role in Byrne's election was also instrumental in her being voted out of office in 1983. In her place came Harold Washington, Chicago's first black mayor (Longworth, 2004: p. 73).

The Washington era was characterized by many new and positive developments in the governance of the city-region. To cite an example, strategies such as the redevelopment of neighborhoods, set in motion a process of reversing the industrial decline which had characterized many of these areas. Part of these efforts involved considerable investments in the physical infrastructure, as well as the designation of manufacturing enclaves and industrial zones (Bennett, 2006: p. 47). Notwithstanding 
these positive developments, much of the Washington's rule was marked by disputes with the city council. These were mostly due to a bloc constituted by two aldermen from the Democratic machine to frustrate the plans of the mayor. The bloc had the loyalty of 29 out of the 50 members of the city council, thus stalling the initiatives of the mayor (Bennett, 2006: p. 47). However, the 1986 special elections resulted in a $25-25$ tie at the city council, thus giving Washington space to pursue his agenda. Moreover, Washington won the 1987 mayoral race with about $54 \%$ of the total votes cast. Unfortunately, his gains were short-lived, as he died of a heart attack in November, 1987. Following this death, Eugene Sawyer, the alderman from the 20th ward was appointed mayor in a temporary capacity (Bennett, 2006: p. 47).

In wake of these developments, the year 1989 witnessed the election of the first Mayor Daley's son Richard to the same office his father had occupied years earlier (Longworth, 2004: p. 73). Unlike his father who focused on creating jobs and investing in massive infrastructural projects, Mayor Richard M. Daley's priority was the provision of amenities which made Chicago a livable city (Longworth, 2004: p. 74). For instance, he oversaw the expansion of O'Hare International Airport and the McCormick Place in the central business district (Bennett, 2006: p. 49). Partly as a result of these initiatives, Daley's reign largely coincided with Chicago's phenomenal transformation into a hub of global economic activity. To begin with, many multinationals, attracted by the metropolitan area's reputation as a hub of a diverse and skilled workforce, as well as subsidiary industries, moved in to cash in on its enviable status of livability (Longworth, 2004: pp. 74-75). Moreover, under the leadership of Mayor Richard M. Daley, Chicago gradually began to shift away from a focus on manufacturing towards the service sector 
as a way of regaining its competitive edge (Simpson, 2006: p. 6). Many of the firms in the service sector were multinational in nature, thus contributing to Chicago assuming its current status as a global city-region (Sassen, 2004: pp. 20-21).

Evidently, the emergence of Chicago as a hub for global economic activity may therefore be attributed largely to the efforts of three mayors: the two Daleys and Harold Washington. The first Mayor Daley was instrumental in the transformation of the Loop into a major location for the activities of service firms. As already noted, this occurred through pro-growth coalitions he formed with members of the business community. Moreover, Harold Washington, despite the challenges he faced at the city council, helped to stem the tide of decline in the city's manufacturing sector. As a matter of fact, some of the initiatives he started lay the groundwork for the ultimate accomplishments of the second Mayor Daley. Richard M. Daley's focus on the creation of a livable city set in motion a process which attracted many multinational corporations to the city. Of course, the presence of well-developed facilities in the Loop (largely attributable to the efforts of the first Mayor Daley) also facilitated the initiatives of Richard M. Daley. It is important to note that due to Chicago's strategic importance in the United States, a first world nation, the city-region upon its transformation was well placed to emerge as a global center for commerce and politics. Besides, the reliance on voluntary partnerships, rather than formal institutions per se, meant that a network and fragmented approach to collective action would result.

Unlike Chicago, the emergence of Accra as Ghana's primate city began after the colonial capital was moved here from Cape Coast in 1877 (Grant and Yankson, 2003: p. 66). Prior to this, Accra was only a little fishing village, a situation quite different from 
other places such as Abidjan and Dakar which assumed capital city status because of the facilities they already possessed (Grant and Yankson, 2003: pp. 66-67). Accra's new status as a capital city attracted capital investments from many wealthy businessmen, thus fueling a growth in trade. Thus, the city's port emerged as the most patronized harbor in the then Gold Coast, now Ghana, as of 1899 (Grant and Yankson, 2003: p. 67). This port served as the city's main gateway with the rest of the world, particularly England. A downtown area, modeled along the lines of what prevailed in Europe, was located close to this port. This downtown hosted many foreign companies and became a leading center for commercial activities such as trade and banking (Grant and Yankson, 2003: p. 67). Also in the 1920s, increases in the volume of cocoa production within the nation's interior, coupled with the presence of the Accra Port helped the city to emerge as a hub of commercial activity (Grant and Yankson, 2003: p. 67).

Upon independence in 1957, the government of Kwame Nkrumah sought to transform Accra into a hub for the economy of Ghana, a situation which resulted in the further concentration of development activities in the city-region (Grant and Yankson, 2003: pp. 67-68). For instance, many administrative offices and buildings emerged in the downtown and the Ministries area (Grant and Yankson, 2003: p. 68). These developments emerged alongside the government's pursuit of economic policies underpinned by socialist ideology. The result was the springing up of many state-owned enterprises with the goal of import-substitution. With the emergence of the Port of Tema on the scene in 1962, and the subsequent development of the Tema township, the Accra Port became defunct (Grant and Yankson, 2003: p. 68). The township of Tema was conceived of as the nation's industrial hub, in contrast with Accra which had traditionally 
performed the role of an administrative and commercial center. In the decades following the Nkrumah regime, various governments pursued policies which promoted the status of Accra as Ghana's primate city. Moreover, while different governments with various ideological orientations emerged, the public sector generally continued to be the primary driver of growth in the country (Grant and Yankson, 2003: p. 68). The dominance of the public sector in the nation's economic and political ethos led to the entrenching of bureaucracy.

By the beginning of the 1980s, public-sector led development appeared to have run its full course. The nation was in a state of economic decline and the military government of the day appeared to have few options for dealing with them. In 1983, the Provisional National Defence Council (PNDC) regime under the leadership of Jerry John Rawlings sought assistance from the International Monetary Fund (IMF) and World Bank in order to deal with the nation's declining economic fortunes. The result was the rolling out of Structural Adjustment Programs under the auspices of these institutions (Briggs and Yeboah, 2001: p. 20). Structural adjustment entailed a change in orientation from public sector-led development to an increased focus on the private sector as a primary driver of economic growth. Specifically, the program called for privatization of several state-owned enterprises, as well as a new bent towards public-private partnerships. Thus, the recent past has witnessed an increased involvement of the private sector in virtually every facet of Ghana's economy, of which Accra occupies an important role (Briggs and Yeboah, 2001: p. 20). Moreover, structural adjustment brought in its wake the need for institutional reforms through the pruning down of a bloated and bureaucratic public sector which had hitherto been the mainstay of the national economy. 
The rolling out of liberal economic policies largely coincided with the increased momentum towards democratic reforms in Ghana. In 1992, due to pressure from the international community, opposition political actors, and civil society groups, the PNDC government presided over the nation's transition to democracy. This transition has been instrumental in accounting for the increasingly important role of Accra in the global economy. First, the change ushered in the longest period of political stability in Ghana's history within a civilian-led framework. This helped to entrench the confidence of both foreign and local businesses towards investing in Accra in particular, and Ghana in general. Second, the transition to democracy signaled a paradigm-shift in the nation's political orientation which had hitherto largely emphasized public sector-led development interventions. Third, the return to democratic rule in the early 1990s led to the emergence of two dominant political parties, both of which have at least a fair amount of leaning towards the private sector. While the National Democratic Congress (NDC), which sprang out of the military-led PNDC regime claimed to be socialist in orientation, its actions in terms of the promotion of foreign direct investment, suggested otherwise due to the economic and political realities of the day. Moreover, the other major political party in Ghana, the New Patriotic Party (NPP), has always believed in free markets and touts itself as a liberal democratic party. Thus, when the NPP came to power in 2001 following the nation's first democratic transfer of power, the government ushered in what is arguably the most sustained period of private-sector led growth in the history of the country.

Under the leadership of John Agyekum Kufuor, an Oxford-trained lawyer and economist, the NPP government bankrolled the "Golden Age of Business" and embarked 
on a vigorous campaign to project Ghana as the destination of choice for private capital. At the institutional level, Kufuor created a new ministry in charge of private sector development. Subsequently, another ministry was created to oversee reforms in the public sector. With respect to economics, the NPP administration ushered in the longest period of macroeconomic stability in over a decade. This helped to engender investor confidence which had been waning in the latter part of the 1990s due to inflationary and balance of payment pressures. Partly in response to some of the economic gains chalked during the NPP's reign, global giants such as Vodafone (from the United Kingdom), as well as Newmont and ALCOA (from the United States) started doing business in Ghana during this time period. Kufuor also presided over the discovery of oil (in commercial quantities) in the West African nation, a situation which resulted in a new influx of multinational corporations, this time round in the oil and gas sector. Under his watch, Ghana moved one notch up from a low-income country to assume a middle-income status. Following subsequent changes in government through the ballot box, both presidents John Atta Mills and John Dramani Mahama have continued to tout the credentials of Ghana as a primary destination for private investment. Due to the nascence of private sector-led development in Ghana coupled with the nation's location in a developing region, Accra upon its exposure to the global economy was more likely to emerge as a globalizing, rather than a full-fledged global city-region. Moreover, as a result of a large public sector, political globalization is mainly institutional in nature. 


\subsection{Summary}

To recap, this chapter has examined how globalization is differentially manifested in Chicago and Accra given their unique local contexts. It observes that Chicago serves as a location for the headquarters of multinational corporations as a result of its prominent global engagement. Accra however hosts subsidiaries or local branches of such firms due to the relatively recent engagement of the private sector in its development. Moreover, Chicago is one of several metropolitan areas in the United States which attract appreciable levels of foreign direct investment (due to the spreading out of such investments across several regions). These investments usually emanate from the developed world as a result of international exchanges associated with North-North cooperation. However, Accra is associated with more than $80 \%$ of Ghana's foreign direct investment because it is a primate city. These investments emanate from both developed and developing countries as a result of North-South and South-South cooperation. There has been an increase in public-private partnerships and civic engagement in the case of Chicago due to its vibrant private sector and strong civic culture. Moreover, Accra has undergone institutional restructuring as a way of reducing bureaucracy associated with public sector-led development. It was observed that strong mayoral politics, especially by the two Daleys and Harold Washington, largely accounted for Chicago's rise as a global city-region. In the case of Accra, liberal economic reforms rolled out in the 1980s and 1990s by the national government under the auspices of the Bretton Woods institutions accounted for its rise as a globalizing city-region. The next chapter looks at how local factors in Chicago and Accra mediate the implications of globalization for regional cooperation in the two metropolitan areas. 


\section{CHAPTER 5}

\section{GLOBALIZATION AND REGIONAL COOPERATION: HOW LOCAL CONTEXTS MATTER \\ Overview}

This chapter examines the differential approaches by Chicago and Accra to regional cooperation in the global era. Specifically, it assesses which metropolitan area adopts a flexible/informal approach (i.e. governance) or a hierarchical/formal mechanism (i.e. government). The chapter therefore situates the global dimensions of inter-local cooperation within place-specific contexts.

\subsection{Comparing Regionalism in Chicago and Accra}

The nature of regionalism in Chicago and Accra (within the global era) may be compared and contrasted on a number of grounds. To begin with, regional cooperation in Chicago can be understood within the lens of new regionalism. Rather than the creation of formal governmental structures, this school of thought emphasizes voluntary collaborative arrangements among existing autonomous local governmental units. The rationale lies in the need to address problems at the most basic level, while ensuring at the same time that the governance process through its fluidity is highly responsive to local issues. Moreover, this arrangement stresses the crucial role played by the private 
sector in fostering regionalism as a way of pooling economic synergies and boosting regional competiveness (Table 5.1). Unlike Chicago, regionalism in Accra proceeds through the creation of formal governmental structures characterized by hierarchical and bureaucratic layers of authority. This arrangement stresses a coordinated approach to development and is relatively less responsive to local issues. Moreover, there is a strong public sector role with the goal of generating collective benefits to the wider society (Table 5.1). The nature of regional cooperation in Chicago and Accra may be summarized as follows:

Table 5.1 Nature of Regionalism in Chicago and Accra

\begin{tabular}{|l|l|l|}
\hline Nature of Regionalism & Chicago & Accra \\
\hline Arrangements & Complex networks & Multitiered/Hierarchical \\
\hline Control & $\begin{array}{l}\text { No central authority } \\
\text { (Governance) }\end{array}$ & Coordinated (Government) \\
\hline Adaptability/Adjustment & Fluid & Administrative/Bureaucratic \\
\hline Participation/Enforcement & Voluntary & Directed \\
\hline Characterization & Informal & Formal \\
\hline Actors & Private sector & Public sector \\
\hline Ideology & Economic logic & Political logic \\
\hline
\end{tabular}

(Source: Author's construct based on literature, discourse analysis, and interviews)

In the case of Chicago, regionalism typifies what Savitch and Vogel (2000) referred to as complex networks. That is, a multiplicity of governmental structures with overlapping responsibilities exists. This kind of arrangement emerges primarily because local governmental units wary of any form of regional government strongly seek to protect their autonomy. Also, decades of mistrust between Chicago's central city and suburbs mean that a regional government is largely not feasible. Moreover, Illinois State law places limits on the level of debt which can be accrued by any local governmental 
unit. As a result, there has been the emergence of special districts to deal with pressing local matters, a situation which adds to the multiplicity of governmental units dotting the landscape.

The network approach to regional cooperation is advantageous because it enables the various local governmental units in the city-region to deal with very specific issues which may not be addressed by a regional government. For instance, county governments attend to matters relating to budgeting and the provision of public infrastructure. Moreover, township authorities are responsible for the maintenance of roads and assessment of property taxes, while municipalities deal with public service provision. The localized nature of decision-making is also epitomized by the presence of special districts which seek to address very specific issues such as water and education. Overall, networked governance has the advantage of promoting local autonomy, while still providing a platform for addressing regional challenges.

However, while this mode of cooperation ensures autonomy, it may also result in a sense of directionlessness. That is, the sheer number of governmental units, coupled with the lack of centralized control may mean the pursuit of conflicting development agendas. With specific reference to Chicago, the city-region has long suffered from a want of an overarching regional development agenda. As a result, localities pursue their own development strategies with little or no cognizance for the implications these have for the wider city-region. This creates tremendous challenges when it comes to attaining regional competiveness in the global era. According to Norris (2001), regional governance does not occur in the absence of formal governmental structures. This finding 
was confirmed in the case of Chicago where the absence of a regional governmental authority led to a network approach to governance

A network approach to regionalism also thrives based on trust and personal rapport among the members of the network. Developing the kind of interpersonal relationships necessary for engendering trust is not always easy to achieve. To begin with, some players within the network may be too concerned about their own local needs and unwilling to make any form of concessions when it comes to attaining a regional development vision. Moreover, other actors, especially within the suburbs, may be wary that what is envisioned as a regional agenda may end up benefitting the central city more. Ultimately, failure to nurture trust breeds tensions and portends negatively for cooperation.

Unlike Chicago, regionalism in Accra epitomizes what Savitch and Vogel (2000) referred to as the multitiered or hierarchical approach. That is, different units of government exist for addressing problems at various spatial scales. Thus, local matters are taken care of by local bodies, with regional issues being addressed by relevant regional bodies. For instance, the various metropolitan and municipal assemblies, as well as their sub-units of government largely cater to local concerns within their jurisdictions. Moreover, regional issues are dealt with by the Greater Accra Regional Coordinating Council.

The existence of the multitiered approach to regionalism may be explained primarily by the need to implement an overarching regional development agenda. As a result, emphasis is placed on the creation of hierarchies with defined lines of authority, so 
that the development process does not proceed in a chaotic fashion. It must also be noted that Accra's long history of public sector-led development accounts a great deal for the presence of bureaucratic structures in relation to regional development. The public sector operates based on formal institutions, and this has led to the emergence of a regional government. The existence of a regional government in Accra lends credence to the assertion by Norris (2001) that metropolitan governance cannot occur in the absence of a formal governmental structure

The hierarchical approach to regional cooperation has the advantage of ensuring a more coordinated approach to regional development. Due to the imperative to implement an overarching development agenda, the mechanism places emphasis on aligning the development goals and objectives of lower level governmental bodies with those at the regional level. Conceptually, this creates clarity of purpose and entrenches a common vision for a region. Moreover, a coordinated approach has the advantage of promoting regional efficiency as the existence of one regional government cuts down on the costs associated with pooling synergies from various local actors in the city-region.

Notwithstanding the merits of the multitiered approach to regionalism, its effectiveness is constrained by the fact that it places emphasis on the creation of new governmental units thus adding to the bureaucratic set-up for dealing with development matters. This is evident in the proliferation of new local governments within the Greater Accra Metropolitan Area over the years. In this institutional approach to regional cooperation therefore, bureaucratic bottlenecks amongst various institutions mean that in many cases, development initiatives are stalled along hierarchical lines of authority. This makes it difficult to attain a common vision for regional development. 
The nature of regionalism in Chicago and Accra may also be compared and contrasted based on the notions of governance versus government. In the case of Chicago, governance is the dominant paradigm. Governance places emphasis on fluid, voluntary, and informal collaboration with the goal of addressing regional challenges. The rationale here is to ensure that cooperation is a proactive and innovative process which responds to the changing needs of the time. Moreover, this arrangement guarantees that in addressing regional problems, local autonomy is not compromised. Thus, it is a horizontal arrangement which entrenches the notion of decentralized decision-making associated with the global era.

Networked governance in Chicago appears to embrace two of the approaches to regionalism identified in the work of Feiock (2009). First, the voluntary nature of collaboration amongst Chicago's localities is akin to what the author referred to as "policy networks." That is, these arrangements are in many cases not legally binding and based on trust amongst the parties involved. Policy networks entrench local autonomy as they emerge from informal interactions amongst actors, with the goal of fashioning out mutually-beneficial relationships. Second, the existence of the Metropolitan Mayors' Caucus typifies what Feiock (2009) referred to as "collaborative groups and councils." These are defined as informal groupings or bodies which serve as platforms for the diffusion of ideas and pooling of synergies towards attaining common goals. The Metropolitan Mayors' Caucus fits into this category as it brings city and suburban mayors together to share ideas and pool efforts, especially when it comes to matters around which some level of agreement exists. 
Unlike Chicago, regionalism in Accra typifies the notion of government. This school of thought stresses that an administrative framework which is directed and formal in nature is crucial towards addressing development challenges. Thus, it is associated with hierarchies and positions filled by staff employed to work towards the attainment of desired goals. The rationale here lies in the desire to ensure a coordinated approach to addressing development challenges. However, in carrying out this goal, local autonomy is usually sacrificed as lower tiers of government usually look up to those at the higher level. The notion of government is therefore a vertical arrangement premised on a centralized decision-making model.

Regional government in Accra also appears to mirror what Miller (2002) referred to as "coordinating regionalism." This arrangement usually relies on an elaborate hierarchical machinery to ensure that the development plans of lower level governments align with regional or national goals. In Accra, this is typified by the existence of several layers of government. To begin with, the National Development Planning Commission deals with overarching issues relating to the planning and coordination of national development. Then comes the Greater Accra Regional Coordinating Council, which serves as a liaison between the central government and the various metropolitan, municipal, and district assemblies in respect of city-regional development. Next, we have the assemblies themselves addressing local development issues such as planning and budgeting. There are also sub-metropolitan layers of government meant to further devolve power administratively. Other institutional layers exist. For instance, the Town and Country Planning Department manages the growth of settlements as a way of promoting efficient and sustainable development. Moreover, the National Disaster 
Management Organization builds capacity and coordinates efforts towards effectively handling disasters in the country.

Another area where regional cooperation in Chicago and Accra may be compared and contrasted is with respect to the involvement of the private and public sectors, respectively. In Chicago, this is largely evident in the number of private organizations involved in various initiatives aimed at promoting regional development. This tradition has been reinforced by the imperative to preserve local autonomy vis-à-vis the metropolitan area's strong civic culture. While the decisions made by many of these private organizations are not legally-binding, they nevertheless create momentum for promoting cooperation. For instance, much of the input responsible for the creation of the Metropolitan Mayors' Caucus by Mayor Richard Daley came from the private sector. Moreover, regional planning is largely carried out by private entities such as the Metropolitan Planning Council. It may therefore be argued that regional cooperation in Chicago is largely based on the "economic logic." This school of thought, associated with scholars such as Peterson (1981) stresses the salience of rational actions and choices by individual actors in the marketplace with the goal of maximizing benefits and minimizing losses. Here, cities behave as efficiency-maximizing corporations which seek to assert their competitive edge in the global economy.

The voluntary nature of cooperation and strong private sector role associated with regionalism in Chicago also lend credence to some of the main assumptions in Sassen's global city model. To begin with, voluntary collaboration connotes the actions of rational actors who make choices based on the benefits and costs involved therein. This aligns with Sassen's emphasis on neoclassical economics. Moreover, a strong private sector role 
in regional cooperation epitomizes the American ethos of capitalism which places emphasis on the interaction of demand and supply forces in the marketplace. This reinforces the Anglo-American nature of Sassen's argument. Besides, strong private sector involvement suggests the pre-eminent role global capital plays when it comes to regional cooperation in Chicago. This lends credence to Sassen's assumption of reductionist Marxism.

Unlike Chicago, regional development within Accra (in the global era) has largely been spearheaded by the public sector. This is due to strong central government control when it comes to the development process. The result has been the relative focus on master plans and strategic planning. However, bureaucratic and coordination challenges mean that these plans are either not implemented or that the goals contained in them are not necessarily achieved (at least not all the time). Thus, the global era has brought in its wake the notion of institutional restructuring with the goal of improving upon administrative efficiency. Public sector-led development aligns with the notion of "political logic" associated with scholars such as Stone (1987). This school of thought stresses that it is paramount to generate collective dividends to society by pursuing development options which serve the public interest. Thus, political actors must make strategic choices and seek to foster partnerships which yield society-wide benefits. In Accra, the political logic is manifested in the emphasis on an overarching national development agenda at the expense of local autonomy. Moreover, the relative absence of the private sector when it comes to regional cooperation lends credence to this assertion.

The administrative and public sector-led nature of regional cooperation in Accra exposes some of the limitations associated with Sassen's global city model. As noted 
earlier, Sassen's model is based on the principles of neoclassical economics and reductionist Marxism, and is Anglo-American in orientation. In the case of Accra, while the global era has resulted in increased private sector engagement, regional cooperation is still largely underpinned by the political logic, rather than the actions of a group of rational actors who seek to maximize profits and minimize losses. This is typified for instance by the relative focus on institutional coordination as a way of fashioning out overarching regional and national development agendas. Moreover, the implicit assumption in Sassen's model that the rise of multinational corporations defies national territorial contexts was also disproved in the case of Accra. This is evident in strong central government control when it comes to with local governance and regional cooperation in the metropolitan area.

\subsection{Regionalism in Chicago}

Given the focus of this chapter, regionalism in Chicago will be discussed in detail with respect to: complex networks; networked governance; fluid, voluntary, and informal collaboration; as well as the private sector and economic logic.

\subsubsection{Complex Networks}

Regionalism in Chicago is an elaborate arrangement comprising many autonomous structures of government. These include the following: county bodies -6 ; township authorities 113; municipal entities - 269; and special districts - 558 (Orum, 2005). These various governmental units are characterized by conflicting responsibilities 
and jurisdictions, thus creating challenges with respect to the coordination of development activities. The 6 county authorities include Cook, Will, DuPage, Kane, Lake, and McHenry (Figure 5.1). Each county body exercises controls within its borders, particularly with respect to local budgeting and infrastructure provision. However, Cook County, which is the largest, has more sweeping authority and a governmental structure comprising a president and a board (Orum, 2005). At the township level, local bodies attend to the needs of relatively small areas in terms of property evaluation, physical infrastructure repairs, and miscellaneous development initiatives. Municipal authorities have the most far-reaching controls, especially with respect to the maintenance of law and order, provision of public services, as well as regulation of thoroughfare access (Orum, 2005). Unlike municipal governments, special districts address specific issues such as the environment, public health, and education which straddle territorial boundaries. Examples include water districts and school districts. These districts have powers such as imposing taxes and allocating financial resources to fund development projects (Orum, 2005). Table 5.2 summarizes some county-level data for the Chicago metropolitan area. 
Figure 5.1 Counties in the Chicago Metropolitan Area

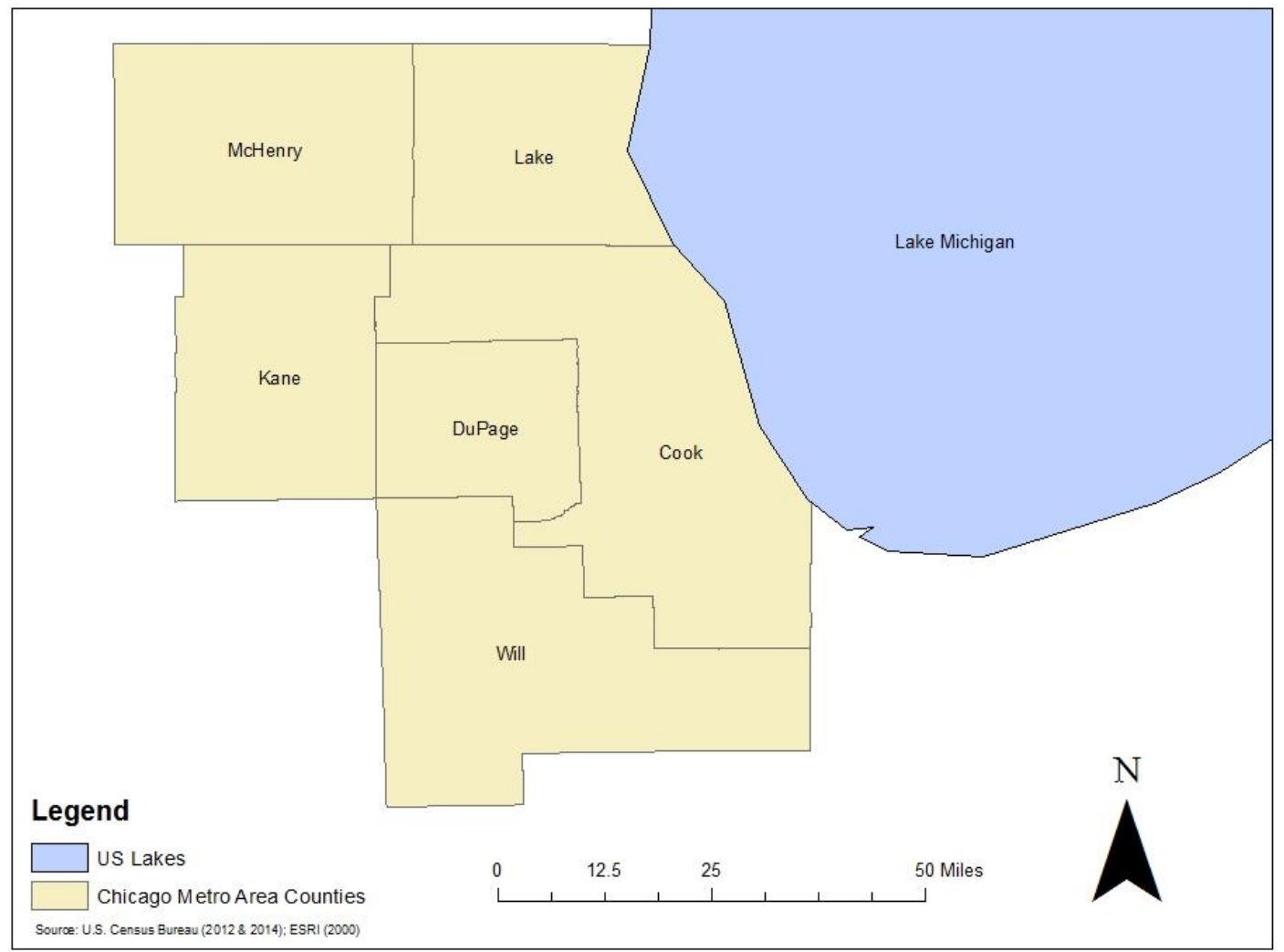

Table 5.2 Chicago Populations and Land Areas Per County

\begin{tabular}{|l|l|l|l|l|}
\hline County/City & Population & $\begin{array}{l}\text { Land Area } \\
\text { (Square } \\
\text { Miles) }\end{array}$ & $\begin{array}{l}\text { Population } \\
\text { Density (Per } \\
\text { Square Mile) }\end{array}$ & $\begin{array}{l}\text { Number of } \\
\text { Localities }\end{array}$ \\
\hline $\begin{array}{l}\text { Cook } \\
\text { (excluding city } \\
\text { of Chicago) }\end{array}$ & $5,194,675$ & 945.33 & $5,495.1$ & 120 \\
\hline DuPage & 916,924 & 327.5 & $2,799.8$ & 30 \\
\hline Kane & 515,269 & 520.06 & 990.8 & 21 \\
\hline Lake & 703,462 & 443.67 & $1,585.6$ & 45 \\
\hline McHenry & 308,760 & 603.17 & 511.9 & 27 \\
\hline Will & 677,560 & 836.91 & 809.6 & 26 \\
\hline Chicago & $2,695,598$ & 227.63 & $11,841.8$ & 50 \\
\hline
\end{tabular}

(Sources: U.S. Census Bureau, 2010; Lindstrom, 2010: p. 42; Zhang, 2013: pp.75-76) 
Local governments in Illinois derive their powers from the State Constitution. The complex nature of regionalism in Chicago may therefore be explained first and foremost by Illinois state policies, with respect to a cap on the level of debts and proceeds which can accrue to a particular unit of local government (Lindstrom, 2010: p. 40). Specifically, the 1870 Constitution promoted the idea of having special units of government. This placed limitations on municipalities, with respect to taxation. Many localities therefore resorted to the creation of special districts as a way of dealing with specific issues or matters arising. For instance, sewage districts, highway districts, and park districts were created in order to establish new tax levies. These levies were crucial towards enabling localities to raise funds for addressing issues of local priority. Even though the creation of special districts enable sufficient attention to be paid to the delivery of services which are largely not catered to by existing governmental units, they also heighten the problem of fragmentation, resulting in an increasingly complex array of governmental structures within the metropolitan landscape.

The complex nature of regionalism in Chicago may also be attributed to the high level of distrust which exists between the central city and suburbs. This occurred in part because prior to World War II, Chicago city politics often dominated the agenda for the entire region. The Democrats who were the power brokers in the city's politics sought to protect their interests across the wider metropolitan area (Squires et al., 1987: p. 71). For instance, these Democrats exercised great control over the Cook County Board of Commissioners which was in charge of law and order maintenance, allocation of resources to the county prison facility and hospital, as well as tax evaluations (Squires et al., 1987: pp. 71-72). Even in suburbs mostly administered as special districts, the 
influence of the central city was evident through the reliance on personnel who previously served in various capacities within Chicago's governmental system (Squires et al., 1987: p. 72). The focus on central city interests resulted in a less cordial relationship between Chicago and suburban politicians (Squires et al., 1987: pp. 72-73). For instance, suburban Republican legislators repeatedly voted down laws at the state level as a way of getting back at Chicago Democrats (Squires et al., 1987: pp. 72-73). As a result of this tense relationship, regional bodies such as the Northeastern Illinois Planning Commission failed to elicit the kind of inter-jurisdictional cooperation necessary for the success of their activities (Squires et al., 1987: pp. 72-73).

Another source of the tensions between Chicago's central city and suburbs relates to the O'Hare International Airport. For instance, the issue of noise pollution associated with the airport is a recurring one. Many suburbs do not appear to favor the extension of O'Hare's runway as they believe this development will compound the problem (Hamilton, 2002: p. 69). Moreover, there are tensions over who should run the airport. After they took control of what had hitherto been a Democrat-dominated legislative body (in the 1994 elections following re-demarcation in 1990), the Republicans sought to create a new state body to control the running of O'Hare International Airport, a move which increased hostility with the central city (Hamilton, 2002: p. 70). In a related development, proposals by the city of Chicago for the creation of a new airport on the South Side were rejected in favor of one in the suburbs of the far south (Hamilton, 2002: p. 70).

Prior to the 1970s, the Illinois State Constitution of 1870 was in force. This document made no direct reference to the "subject" of inter-local cooperation. The 1870 
constitution was promulgated at a time when Illinois was predominantly rural in character and Chicago was not nearly as urbanized as is the case presently (Lousin, 1988: p. 573). Over the course of time, amidst rapid urbanization, it became evident that there was the need for an entirely new constitution more in tune with the needs of current and future generations (Lousin, 1988: pp. 573-574). This realization culminated in the convening of the "Sixth Illinois Constitutional Convention" and the drafting of a new state constitution, subsequently approved by the electorate in December, 1970 (Lousin, 1988: p. 574). It was only after the 1970 Illinois Constitution was promulgated that things began to change with regard to inter-local cooperation. This new law provided cities such as Chicago with the power of "home rule" as a way of reversing Dillon's Rule which had hampered the ability of localities to deal with pressing challenges on their own. The 1970 Constitution also empowered localities to embark on regional cooperation as a way of addressing inter-jurisdictional problems (Orum, 2005). Specifically, Article 7(10a) of the new constitution states that:

\footnotetext{
"Units of local government and school districts may contract or otherwise associate among themselves, with the State, with other states and their units of local government and school districts, and with the United States to obtain or share services and to exercise, combine, or transfer any power or function, in any manner not prohibited by law or by ordinance. Units of local government and school districts may contract and otherwise associate with individuals, associations, and corporations in any manner not prohibited by law or by ordinance. Participating units of government may use their credit, revenues, and other resources to pay costs and to service debt related to intergovernmental activities."
} 


\subsubsection{Networked Governance}

In the global era, one main vehicle for carrying out inter-local cooperation in the Chicago city-region is the Metropolitan Mayors' Caucus (Lindstrom, 2010: p. 43). Towards rationalizing the creation of this caucus, the accomplishments of a previous initiative (i.e. the suburban Councils of Government) must be kept in mind. The suburban Councils of Government emanated largely from monthly gatherings by four suburban mayors during the 1950s, 60s, and 70s (Lindstrom, 1998: p. 330; Lindstrom, 2010: p. 43). These platforms were aimed at fashioning out joint solutions to problems confronting these suburbs. For instance, the Northwest Municipal Conference focused on matters such as waste management, land use regulations, and the sharing of water resources. Based on the "Surface Transportation Assistance Act," emphasis during the 1970s soon shifted towards providing for the transportation needs of this region (Lindstrom, 1998: p. 330). Beside the element of voluntariness, collaboration was also necessitated by a national stipulation to this effect, particularly with respect to transportation. This occurred during the 1970s and 1990s, respectively, in the form of "councils of mayors" and in terms of the "Intermodal Surface Transportation Efficiency Act" (Lindstrom, 1998: p. 330). For instance, the West Central Municipal Conference emanated from the "Central Region Council of Mayors" and initially focused on matters relating to transportation, before being transformed into its current form (Lindstrom, 1998: p. 331). There were also "inter-governmental councils" whose members included governments at the county level. For instance, the DuKane Valley Council was made up of the Kane and DuPage County governments, as well as envoys from various communities, districts, corporate entities, institutions of higher learning, and service providers (Lindstrom, 1998: 
p. 331). Finally, some councils emerged to address land use matters. To cite an example, the Barrington Area Council of Governments arose partly in response to plans to put up 18,000 housing complexes within South Barrington (Lindstrom, 1998: p. 331).

The genesis of the Metropolitan Mayors' Caucus was in 1997 when Mayor Richard M. Daley participated in the Northwest Municipal Conference upon request. At the gathering in April, it was noted that cooperation between the city of Chicago and its suburbs held the key to dealing with pressing issues such as the supply of electricity and innovations in the telecommunications sector (Lindstrom, 2010: p. 44). Following this meeting, Mayor Daley attended another forum in August. This new gathering was spearheaded by the Elk Grove Village Chamber of Commerce and brought together various corporate and city leaders. At this conference, the mayor stressed the salience of inter-jurisdictional collaboration, noting that it would address pressing challenges in areas such as transportation, the environment, power supply, and the training of the region's labor force (Lindstrom, 2010: p. 44). Three months later, Mayor Daley invited the various suburban mayors to an Economic Development Forum. This meeting, which took place on December 2, stressed the role of cooperation in enhancing the competitive edge of the city-region. It therefore called for the establishment of the Metropolitan Mayors' Caucus towards achieving this goal. The forum called for gatherings, four times in a year, comprising representatives from the various suburban Councils of Government (Lindstrom, 2010: p. 44).

As it currently exists, the Metropolitan Mayors' comprises a chairman, vice chairman, secretary, an executive board and several other committees or task forces. These committees or task forces attend to various regional issues such as sanitation, 
community and economic development, transportation, service delivery, energy, and telecommunications. The Metropolitan Mayors' Caucus typifies a network approach to governance because it brings together mayors, as well as relevant public and private actors towards fashioning out solutions to problems confronting the city-region. Moreover, it places emphasis on consensus-building, rather than legally-binding powers to attain its goals. Thus, it was decided at the time of its founding that only those matters around which compromise could be achieved, would form the primary focus of the caucus, at least in the initial stages. Areas of contention, such as the extension of O'Hare International Airport would be deferred until further notice (Lindstrom, 2010: pp. 45-47).

The imperative for cooperation appears to have outlived the Daley era, during which the mayors' caucus emerged. To cite an example, current Mayor Rahm Emanuel and the President of Cook County, Toni Preckwinkle, launched an initiative in March, 2011 to promote collaboration between the city and the county. As part of this endeavor, a committee was constituted to fashion out potential areas for cooperation. The committee presented its findings three months later, identifying 19 key areas around which Chicago and Cook County could collaborate (Joint Committee on City-County Collaboration, 2012: p. 1). Following the presentation of the committee's report, various groups were constituted to fashion out modalities for implementation. These groups meet regularly to pool ideas and map the way forward. Moreover, city and county officials have been meeting on a regular basis to evaluate progress and plan for the future. After only a few months of implementation, the collaboration between Chicago and Cook County resulted in projected cost savings of \$11 million (Joint Committee on CityCounty Collaboration, 2012: p. 1). It is also envisaged that cooperation would result in 
improvements to the quality of service delivery. Moreover, it is hoped that collaboration in the 19 key areas would result in a "snowball effect," spurring collective action in many other areas (Joint Committee on City-County Collaboration, 2012: p. 1).

The network approach to governance in Chicago, as typified by the presence of bodies such as the Metropolitan Mayors' Caucus and the Joint Committee on CityCounty Collaboration may be explained first and foremost by the lack of a formal regional government. This absence of regional government is attributable to the entrenched culture of local autonomy among the various individual governmental units. Many localities seek to protect their autonomies in order to escape the main challenges (such as crime and poverty) associated with the central city. Autonomy is also perceived as a viable way of addressing purely local matters which may attract less attention from relevant governmental authorities.

The existence of networked governance also lies in the desire by various localities to pool synergies towards effectively dealing with regional problems. This is important as a result of the inter-jurisdictional nature of challenges such as water, transportation, and housing issues. A network approach to governance (through inter-local cooperation) therefore enables solutions to be implemented at the scale at which a problem occurs. This serves to promote efficiency through economies of scale and avoids duplication of resources. Moreover, networked governance helps to create a common voice for articulating regional issues. This yields positive results for both big and small communities. For instance, through the platform of the Metropolitan Mayors' Caucus, localities in both the central city and suburbs come together to deliberate on issues of mutual concern. This is possible because the caucus has promoted trust and team- 
building amongst the various mayors in the region. The rapport among the mayors arises due to the fact that Mayor Richard Daley, who was the founding chairman of this body, stressed the need for it to focus on issues around which some level of agreement exists.

\subsubsection{Flexible, Voluntary, and Informal Collaboration}

Even though the Illinois State Constitution provides a general framework for localities to collaborate, the way cooperation is specifically carried out is largely determined by the issues at hand and the parties involved. Inter-local cooperation in Chicago may therefore be described as a fluid, voluntary, and informal process. The fluidity of cooperation is typified by its responsiveness to pressing regional needs at any point in time. For instance, under the auspices of the Metropolitan Mayor's Caucus, collaboration was initially focused on regional economic development. Emphases later shifted to regional power supply, regional transportation, pension reform, and a regional compact for promoting sustainability. The caucus has also worked with the Illinois Congressional delegation on transportation funding and provided models on housing policies for local governments. Besides fluidity, voluntariness entails the element of noncompulsion when it comes to collaboration amongst various localities. For instance, localities decide when to cooperate based on their own accord. They are also at liberty to figure out what matters are of priority to them. Moreover, the informal nature of cooperation lies in the fact that agreements among localities are in many cases not legally binding. Informality also implies the lack of a formal regional government, meaning that cooperation takes place in a non-hierarchical manner. 
Towards enabling them to share resources or achieve common goals for the region, localities can enter into memorandums of understanding, inter-local pacts, and boundary agreements. The various county and local governments play research and advocacy roles when it comes to inter-local cooperation. They also pilot projects which test the feasibility of regional cooperation. The roles played by the city of Chicago when it comes to regionalism however depend a lot on who the mayor is. Thus, while some mayors have made cooperation a top priority, others have not necessarily done so. For instance, the Daley administration played a leading role in promoting cooperation; and this was crucial towards the birthing of the Metropolitan Mayors' Caucus. Moreover, the state and federal governments have an important part to play. For instance, the federal government has the power to prioritize initiatives with a regional focus or scope.

The fluid, voluntary, and informal nature of collaboration among localities in Chicago may be explained partly by the strong civic culture in the city region. This culture promotes dialogue and understanding amongst actors, a strategy which helps to build trust towards fashioning out common solutions to challenges (Hamilton, 2002: p. 65). Moreover, a strong civic culture creates a platform within which actors begin to see beyond their myopic, individual needs to focus on broader region-wide goals and objectives. The ability of civic bodies to build consensus emanates from their nonpartisan nature, which make it possible for them to bring together many players from across the political divide (Hamilton, 2002: p. 65). Also, these bodies serve as platforms where political and business leaders meet towards pooling synergies for addressing regional problems. Moreover, civic bodies have the ability to mobilize human and other resources necessary for bringing actors around the table (Hamilton, 2002: p. 65). 
The nature of regional cooperation in Chicago can also be perceived as a strategy for reducing the rancor which has traditionally characterized relations between actors in the central city and suburbs. As a result of this fractious relationship, any attempt at creating a regional government is likely to fail or at best become ineffective. Thus, localities coming together on their own accord help to achieve solutions to regional problems, while ensuring that neither the central city nor suburbs are unduly favored in any such efforts. For instance, the various local governments cooperate when it comes to less-controversial issues like energy-efficiency. This helps to build trust and forge consensus at the regional level. The Metropolitan Mayors Caucus is crucial in this respect as it results in the evolution of a regional agenda, largely devoid of the rancor associated with partisan politics. Ultimately therefore, the nature of collaboration in Chicago may be explained by an institutional vacuum at the metropolitan level, implying that regional solutions are best fashioned out through legally non-binding agreements among localities.

\subsubsection{The Private Sector and Economic Logic}

Due to the high level of local autonomy which exists in Chicago and many other American urban areas, public authorities face tremendous challenges when it comes to fashioning out regional solutions to common problems which confront localities. Thus, the private sector plays a pivotal role in promoting regional initiatives (Hamilton, 2002: p. 63). The role of the private sector usually emanates from the fact that their economic and other interests are regional, rather than local in scope (Hamilton, 2002: p. 66). This situation has been reinforced by the reality that historically, "the local politics of American cities have depended for their actors, and for a good deal of their subject 
matter, on the changing focus of men's private economic activities" (Warner, 1987: p. 4).

During the 1960s, private sector efforts at promoting regionalism occurred through campaigns for the redrawing of boundaries by means of annexation and other mechanisms. However, the attempts were largely unsuccessful due to the entrenched desire by localities to preserve their autonomies (Hamilton, 2002: p. 64). As a result, the role played by the private sector in the global era primarily focuses on the creation of platforms for collaboration amongst autonomous local governmental units in order to attain regional efficiency (Hamilton, 2002: pp. 63-64). The defining feature of this arrangement is that it relies on networks among partners in order to build consensus and yield mutually-beneficial solutions to problems (Hamilton, 2002: pp. 63-64).

The role of the private sector when it comes to regionalism in Chicago goes as far back as the 1800s. In 1877, The Commercial Club of Chicago was founded by a group of persons in the business community with the objective of entrenching a civic culture and promoting cooperation in the city-region. In 1909, the group spearheaded the promulgation of the Plan of Chicago through the inputs of Daniel Burnham (The Commercial Club of Chicago, 2013). In 1970, The Commercial Club, through the influence of Samuel W. Witwer played a pivotal role in advocating for a new constitution for the State of Illinois (The Commercial Club of Chicago, 2013). As already noted, this new constitution largely enshrined the practice of inter-local cooperation within a legal framework. In 1983, The Commercial Club sponsored a "Jobs for Metropolitan Chicago" research, eventually resulting in the formation of the Civic Committee (The Commercial Club of Chicago, 2013). 
The Civic Committee had the goal of formulating policies which would enhance the competitive edge of the city-region. These included plans for training Chicago's skilled and unskilled labor, as well as improving educational standards. As regards O'Hare International Airport, there were efforts to build more airstrips. Also, the Civic Committee spearheaded the creation of World Business Chicago, a collaborative venture between the public and private sectors, as a way of providing an enabling environment for the flourishing of private enterprises (Lindstrom, 2010: p. 48). In 1985, the Civic Committee was tasked by Mayor Harold Washington to assess the state of Chicago's finances towards sustaining its development goals over the long haul. The committee, acting in concert with Chicago United, pooled the experiences of over 70 experts who proffered various solutions towards the financial stability of the city (The Commercial Club of Chicago, 2013). This initiative eventually led to the emergence of the Civic Consulting Alliance (Civic Consulting Alliance, 2015). Moreover, the Chicago Enterprise Center (currently known as Chicago Entrepreneurial Center) was established in 1986 by the Civic Committee to boost the entrepreneurial efforts of actors in the private sector. In 1989, the Illinois Coalition, (now referred to as the Illinois Science and Technology Coalition), was created with the support of the Civic Committee. This was aimed at promoting economic wellbeing, premised on investments in technology (The Commercial Club of Chicago, 2013).

In the year 1999, private sector actors in Chicago under the auspices of The Commercial Club embarked on a regional endeavor known as Chicago Metropolis 2020 (Hamilton, 2002: p. 63; Johnson, 1999). This initiative stresses the salience of the regional imperative by observing the inherent inter-linkages between Chicago's central 
city and suburbs. For instance, it notes that $\$ 14$ billion in earnings accrue per annum to suburbanites working in the central city (Johnson, 1999: p. 3). Moreover it underscores the need to enhance the competitive edge of the city-region through the attraction of world-class talent. This, it observes, would provide employers in the metropolitan area with the variety of skill sets they need (Johnson, 1999: p. 3). The initiative also notes that regionalism is crucial towards stemming the tide of spatial inequality between the central city and suburbs (Johnson, 1999: p. 4). Moreover, regionalism holds the key to increasing the accessibility and use of transportation, education, and recreational resources for all residents (Johnson, 1999: pp. 3-4). The initiative also underscores the need for localities to fashion out their development agendas, taking cognizance of the ramifications their choices have for the wider region (Johnson, 1999: p. 47).

In 2011, a body known as Metropolis Strategies emerged. This entity serves to replace Chicago Metropolis 2020, an earlier initiative by The Commercial Club. Through research, civic engagement, and advocacy, Metropolis Strategies helps to create platforms for Chicago's public and private actors to pool their efforts towards enhancing the competitive edge of the city-region (Metropolis Strategies, n. d.). The organization was also instrumental in the fusion of the Chicago Area Transportation Study (CATS) and the Northeastern Illinois Planning Commission (NIPC) to create the Chicago Metropolitan Agency for Planning (CMAP). Unlike its predecessors, CMAP helps to ensure a comprehensive approach to transportation and land-use planning for the Chicago Metropolitan Area (Metropolis Strategies, n. d.). Metropolis Strategies has also played a pivotal role in spearheading private sector efforts towards reforming Chicago's Regional Transportation Agency (RTA). These reforms seek to enhance the financial situation of 
the RTA and create a more coordinated regional transportation system (Metropolis Strategies, n. d.).

The Metropolitan Planning Council (an independent, private, and non-profit agency) is another body which comes to mind with respect to regionalism in the Chicago metropolitan area. This body promotes livability through the fashioning out of solutions to planning and development problems within the metropolitan area. It accomplishes this through partnerships with both public and private players. In the global era, the role of this organization has become more paramount due to the pressing need to promote governance efficiency in the city-region (Metropolitan Planning Council, 2015). Towards realizing this and other goals, the Metropolitan Council designed a 2014 Plan for Prosperity. The main goal of the plan is to boost economic growth and competitiveness. Specifically, it aims to attain this through: strategic investments in infrastructure; the sourcing of alternative financing for development; and reductions in government overhead expenditures through cost-cutting mechanisms such as the pruning down of the number of governmental structures (Metropolitan Planning Council, 2014).

\subsection{Regionalism in Accra}

Unlike Chicago, regionalism in Accra will be discussed with respect to: hierarchical/administrative restructuring; regional government; administrative, directed, and formal collaboration; as well as the public sector and political logic. 


\subsubsection{Hierarchical/Administrative Restructuring}

Accra has four layers of government comprising: the national government as well as associated ministries, departments, and agencies; the Greater Accra Regional Coordinating Council; "metropolitan, municipal, and district assemblies;" and sub-district governmental units such as "urban, zonal, and town councils," as well as "unit committees" (Ayee, 2012: pp. 6-7). The various governmental units deal with development problems at different spatial scales (Ayee, 2012: pp. 6-7). This is aimed at ensuring a comprehensive or holistic approach to the development process. For instance, the central government addresses nation-wide development issues, while the regional coordinating council is in charge of regional development coordination (Ayee, 2012: pp. 6-8). Moreover, the metropolitan municipal, and district assemblies perform various duties with respect to governance, resource allocation, and planning at the sub-regional level. For instance, they provide basic services in education and environment at the local level and raise funds through property taxes and other mechanisms (Ayee, 2012: p. 6). Also, the sub-district units of government deal with development issues at the lowest spatial scale (Ayee, 2012: p. 8).

As of 1960, the Accra Capital District (as the Greater Accra Region was then known), was located in Ghana's Eastern Region. This notwithstanding, the territory was run as a separate political entity by the central-government appointed local government minister due to its priority status. In 1982, based on the provisions of the Provisional National Defence Council Law 26, the Greater Accra Region was carved out as a new geographical unit, with its own administration (Government of Ghana Official Portal, 2014). This move sought to enhance administrative efficiency and speed up the 
development of the city-region through increased resource allocations. Currently, the Greater Accra Metropolitan Area has the highest urban population in Ghana (Ghana Statistical Service, 2012). For many years after Ghana's local government reform program of 1988, the Greater Accra Metropolitan Area comprised three main units of government: the Accra Metropolitan Assembly (AMA), the Tema Metropolitan Assembly (TMA), and the Ga Municipal Assembly (GMA). The AMA comprises the largest and most urbanized area within the city-region, followed by the TMA and GMA (Figure 5.2).

Over the years, there has been a proliferation in the number of local governmental structures in Ghana, thus adding to the bureaucratic layers associated with regionalism in the Greater Accra Metropolitan Area. This development may be explained by the establishment of new metropolitan, municipal, and district assemblies; an important feature of Ghana's local government reform, launched in 1988 (Ayee, 2012: p. 8). The emergence of new local governmental units is aimed in part at ensuring administrative efficiency through the devolution of powers from relevant central government ministries, departments, and agencies to local bodies. The goal is to reduce over-centralization, an attribute inherited from the days of British colonialism. Reducing centralization is important as a way of preventing local and regional development from becoming stalled along hierarchical chains. Moreover, it is believed that when powers are transferred from central to local government bodies, this would result in more local engagement with respect to the development process. 
Figure 5.2 Some Local Governmental Units in Accra

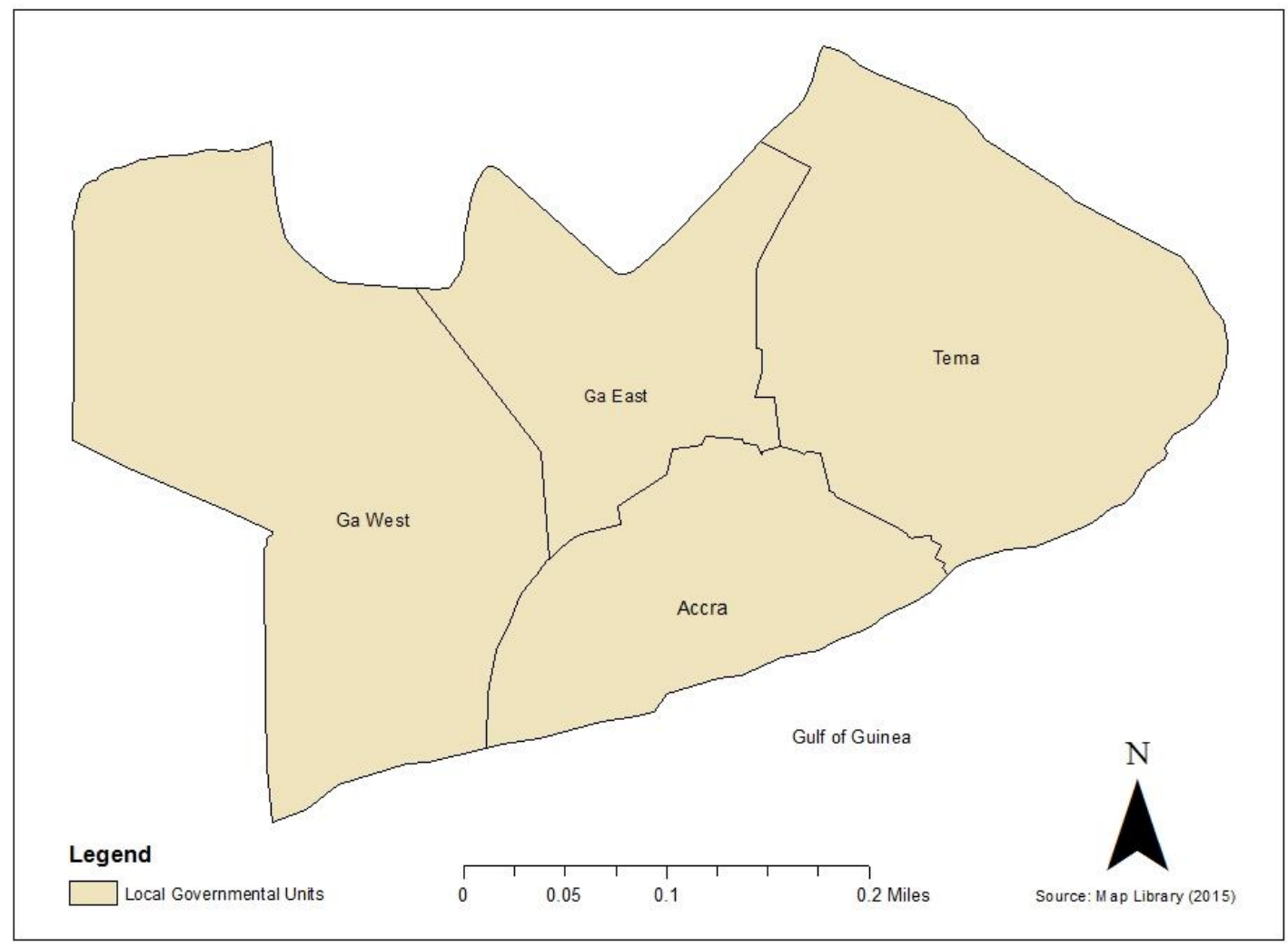

Ghana’s 1992 Constitution, as well as the 1993 Local Government Act (i.e. Act 462), provide the legal mandate for the establishment of new local governmental units in the country. Specifically, the constitution states in Article 241 (2) that Parliament has the legal authority to make decisions with respect to redistricting. This notwithstanding, Section 1(2) of Act 462 stipulates that the President has a pre-eminent role when it comes to the establishment of new local governmental units. For instance, the President can employ executive power to create and name a locality. In carrying out this mandate, he/she is obligated by law to seek advice from the Electoral Commission (even though 
the commission's proposals are not legally-enforceable). Moreover, Section 1(4) of Act 462 defines three main criteria for the creation of metropolitan, municipal, and district assemblies. These include population threshold, territorial propinquity, and economic feasibility. For instance, a metropolitan assembly is defined as having a minimum population threshold of 250,000 residents. Also, a municipal assembly must have at least 95,000 people and comprise a dense residential area. Moreover, a district assembly should not be made up of less than 75,000 residents (Ayee, 2012: p. 10). In all cases, the established unit of government should have at least some facilities (e.g. roads and markets) and revenues which would enable it carry out its responsibilities effectively.

Per the provisions of Act 462, President John Agyekum Kufuor presided over the creation of 32 new local governmental units between 2004 and 2008. This development resulted in the emergence of several new municipalities within the Greater Accra Metropolitan Area. For instance, the Ledzokuku-Krowor Municipal Assembly was carved out of the Accra Metropolitan Assembly. Moreover, the Ashaiman and Adentan municipalities emerged from the Tema Metropolitan Assembly. Also, the Ga Municipal Assembly was split in three: Ga East, Ga South, and Ga West. In 2012, the establishment of 46 additional local governmental units countrywide by President John Atta Mills led to the emergence of three new municipalities in the Greater Accra Metropolitan Area. These were La Dade-Kotopon, La-Nkwantanang-Madina, and Ga Central. La Dade-Kotopon was carved out of the Accra Metropolitan Assembly, while La-Nkwantanang-Madina was created from the Ga East Municipal Assembly. Also, Ga Central emerged out of the Ga South Municipal Assembly (Ministry of Local Government \& Rural Development and Maks Publications \& Media Services, 2006). Figure 5.3 shows the new local 
governmental boundaries, while Table 5.3 summarizes information about some major local governmental units.

Figure 5.3 Current Local Governmental Boundaries in the Greater Accra Metropolitan Area

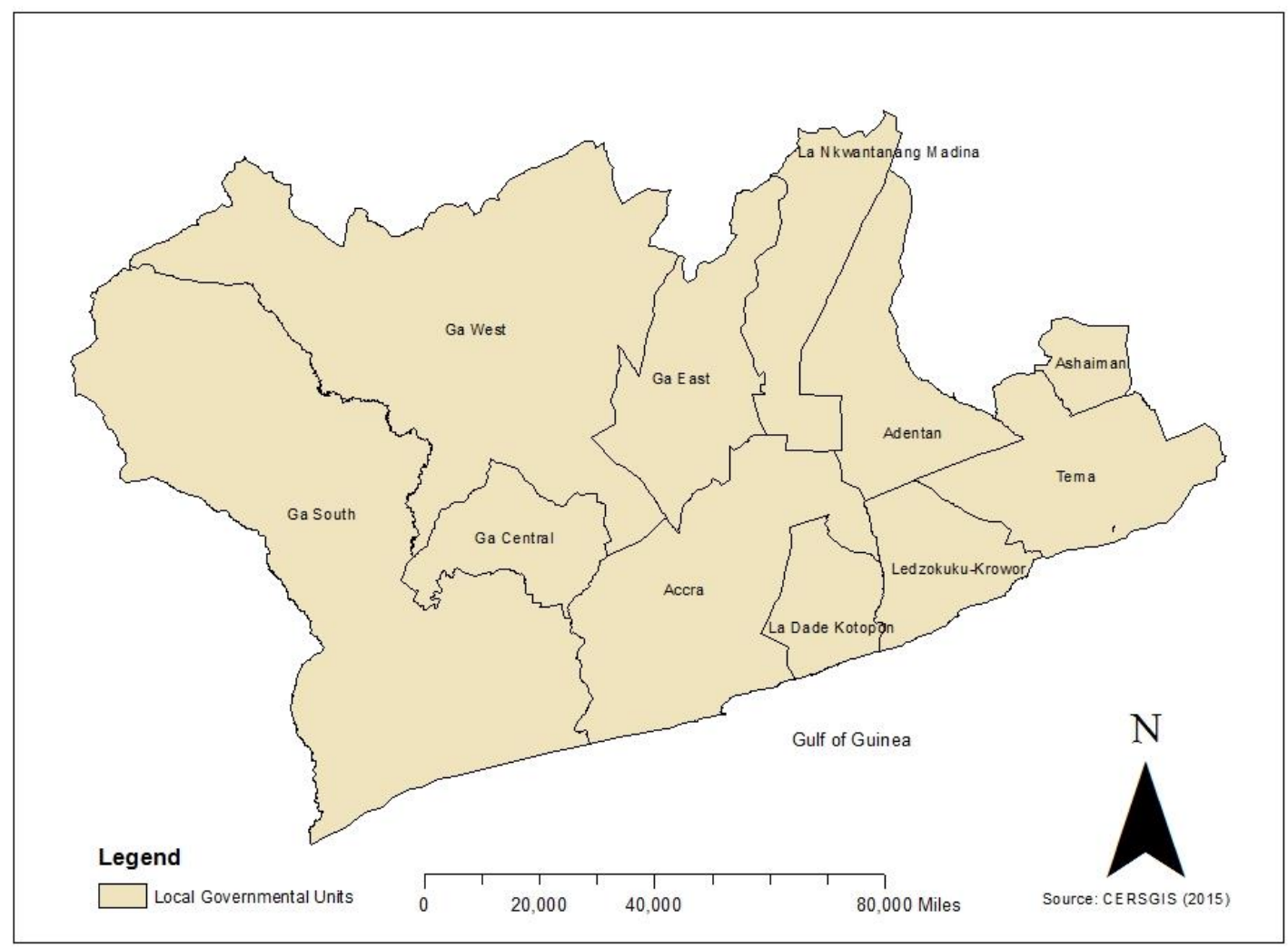


Table 5.3 Accra Populations and Land Areas Per Local Governmental Unit

\begin{tabular}{|l|l|l|l|l|}
\hline $\begin{array}{l}\text { Local } \\
\text { Government }\end{array}$ & Population & $\begin{array}{l}\text { Estimated } \\
\text { Land Area } \\
\text { (Square Miles) }\end{array}$ & $\begin{array}{l}\text { Estimated } \\
\text { Population } \\
\text { Density (Per } \\
\text { Square Mile) }\end{array}$ & $\begin{array}{l}\text { Estimated Number } \\
\text { of Sub-Metros/ } \\
\text { Zonal Councils }\end{array}$ \\
\hline $\begin{array}{l}\text { Accra } \\
\text { Metropolis }\end{array}$ & $1,848,614$ & 77.61 & $23,819.28$ & 11 \\
\hline $\begin{array}{l}\text { Ledzokuku- } \\
\text { Krowor }\end{array}$ & 227,932 & 19.31 & 11803.83 & 2 \\
\hline Ga West & 262,742 & 115.67 & $2,271.48$ & 6 \\
\hline Ga East & 259,668 & 33.1 & $7,844.95$ & 3 \\
\hline Ga South & 485,643 & 131.98 & 3679.67 & 3 \\
\hline Adentan & 78,215 & 358.46 & 218.2 & 4 \\
\hline Ashaiman & 190,972 & 17.37 & $10,994.36$ & 7 \\
\hline Tema & 402,637 & 142.47 & $2,826.12$ & 6 \\
\hline
\end{tabular}

(Sources: Ghana Statistical Service, 2014 \& 2010; UN-Habitat, 2009; Ministry of Local

Government \& Rural Development and Maks Publications \& Media Services, 2006;

Ministry of Food \& Agriculture - Republic of Ghana, 2015; Ga West Municipal

Assembly, 2006; Ga South Municipal Assembly, 2014; Ledzokuku-Krowor Municipal

Assembly, 2015; Accra Metropolitan Assembly, n.d.; Tema Metropolitan Assembly, n.d.)

\subsubsection{Regional Government}

In the global era, the various metropolitan, municipal, and district assemblies within the Greater Accra Metropolitan Area operate under the auspices of the Greater Accra Regional Coordinating Council. This public entity cements central government control by serving as a liaison between the assemblies and the Government of Ghana, and also supervising the activities of these assemblies. It serves to engender regional cooperation by bringing together the chief executives of the various assemblies, traditional leaders, as well as the heads of deconcentrated government departments and agencies (Government of Ghana Official Portal, 2014; Ayee, 2012: p. 8). Usually, interactions among these actors towards fostering the development of the city-region take place through formally organized workshops and seminars. These fora serve as platforms 
where issues of common concern are discussed towards forging a common regional development agenda. Moreover, they serve as opportunities for networking with development partners such as non-governmental and international organizations.

Even though institutional structures (such as the regional coordinating council) exist for promoting collective action, inter-local cooperation is not necessarily a preeminent issue due to coordination and bureaucratic bottlenecks. As a result, whether or not cooperation actually occurs depends a lot on the personal rapport between the central government-appointed Greater Accra Regional Minister on the one hand and the various metropolitan, municipal, and district chief executives on the other hand. Some ministers and chief executives have been very instrumental in promoting regional cooperation, while others have not made this such a top priority. Moreover, the desire to see the vision of government implemented across the city-region influences whether or not collaboration occurs. In certain cases at least, cooperation is inevitable because the regional minister and various chief executives have to work together before the agenda of the central government for the city-region can be achieved. This helps to boost the electoral fortunes of the central government and also enables government appointees to keep their jobs.

It is also important to note that tensions exist between various assemblies over issues of boundaries and revenue collection; and these portend negatively for inter-local cooperation. For instance, in the Ayawaso sub-metro, particularly in areas around East Legon-Nungua New Town, the TMA sometimes collects revenues and issues building permits within AMA territory. Similar tensions between the AMA and TMA occur in the Kpeshi sub-metro, especially in the territory around the Nautical College (Ministry of 
Local Government \& Rural Development and Maks Publications \& Media Services, 2006). The disputes over boundaries and revenues sometimes occur in light of the creation of new local governmental units which makes it difficult to know which jurisdictions some localities fall under. Besides, given the desire by localities to maximize their revenue-collection bases, they are usually keen to lay claim over disputed territories, especially when these areas have great economic and revenue-generation potentials. Also, the boundaries of areas administered by traditional leaders do not always coincide with those formally established by the central government; and this creates challenges for localities which belong in officially-designated local governmental areas different from their traditional jurisdictions.

The existence of a regional government in Accra may be explained first and foremost by the desire to ensure a coordinated approach to the development process. It is strongly believed that in the absence of such structures, localities will pursue contradictory development strategies. Besides, this arrangement is aimed at avoiding a situation where some localities are left behind for want of a development vision. The coordinated approach is also perceived as the most prudent way of protecting the overarching national interest. This is because it ensures all development strategies (i.e. at the local, regional, and national levels) are in sync with each other.

The presence of a regional government also seeks to promote regional efficiency in the development process. This is due to the belief that the lack of such a structure would portend considerable cost expenses in bringing various actors together towards fashioning out common development goals. Moreover, rather than having several different bodies which address matters of regional development, it is asserted that the 
existence of an officially-designated entity (such as the Greater Accra Regional Coordinating Council) would promote economies of scale.

Ultimately, regional government in Accra can be explained in light of a long history of public sector-led development inherited from the days of British colonial rule. This orientation seeks to address development challenges through the creation of formal governmental structures. The creation of such structures provides the right institutional and legal frameworks for the execution of development goals. Moreover, the emergence of such arrangements is crucial towards a coordinated approach to the development process.

\subsubsection{Administrative, Directed, and Formal Cooperation}

Regional cooperation in Accra may be described as administrative, directed, and formal in nature. The administrative nature of cooperation is evident because the various local governmental units work together under the auspices of the Greater Accra Regional Coordinating Council. Moreover, the fact that cooperation is usually implicitly enshrined in the modus operandi of these governmental bodies lends credence to this assertion. The directed nature of cooperation emerges because collaborative efforts may be at the behest of the central government towards whipping localities in line to implement its agenda for the city-region. Moreover, even in situations where the central government does not explicitly direct localities to cooperate, the formal job descriptions of the Greater Accra Regional Minister, as well as the Minister of Local Government and Rural Development, 
inherently make it imperative for them to pool the efforts of these various local governmental units.

The local governments in Accra work together when the need arises for them to do so, without necessarily signing any agreements or memoranda of understanding. This is due to the fact that these assemblies operate within a wider regional institutional framework which makes collaboration an implicit component of their operations. The administrative, directed, and formal nature of regional cooperation may thus be attributed in part to the presence of a regional governmental body such as the Greater Accra Regional Coordinating Council. This body is characterized by hierarchies and channels with defined lines of authority as a way of avoiding the pursuit of helter-skelter development policies. Thus, cooperation occurs within stipulated institutional platforms, rather than by voluntary actors.

Regional cooperation is also informed in part by the desire of localities to ensure that the development agenda of the central government for the city-region is attained. This motivation is derived from the fact that the chief executives and one-third of the members of the various assemblies are nominated by the government of the day. As a result, implementing central government agenda yields direct political dividends for these appointees. Moreover, in light of the fact that Ghana is a unitary state, development is usually conceived of in national, rather than local contexts. There is therefore the need to pool efforts by all relevant actors in the city-region towards attaining desired common goals. 
The nature of cooperation in Accra may also be explained by the need for a comprehensive approach to dealing with pressing regional development issues. For instance, when it comes to waste management, the location for a potential landfill site may be outside the borders of a particular assembly; and this calls for a coordinated arrangement among the various assemblies towards arranging for the use of such a site. Waste management by its nature requires huge capital outlays, which are usually beyond the scope of just one assembly, especially the newly established ones. Thus, cooperation is necessary as a way of pooling financial and human efforts towards effective regional development. Moreover, in terms of water supply, cooperation is important in order to deal with systemic inefficiencies in supply. This occurs partly because the source of water supply may straddle the boundaries of several assemblies. Also, such forms of collaboration may be necessary to ensure proper coordination and support of the activities of the Ghana Water Company Limited.

\subsubsection{The Public Sector and Political Logic}

Regionalism in Accra is conceived of as a public endeavor. This development, attributable to a historical legacy inherited from the colonial era, helps to protect the overarching national interest. Due to the profit motive of the private sector, successive governments in Ghana over the years have placed emphases on the public sector as the primary driver of regional development. It is asserted that the public sector is better suited to addressing regional development issues because its main focus is to serve the collective interest of society, usually through the initiative of political actors. 
Two developments in particular lend credence to the dominance of the public sector with respect to regionalism in Accra: the existence of institutions to this effect; and the fact that regional development is guided by a master planning process. One institution which typifies the public orientation of regionalism is the Local Government Service. Created in 2003 under the Local Government Service Act i.e. Act 656, this body ensures the "effective administration and management of local government" in Ghana (Local Government Service, 2013). Part of this mandate entails assisting the various local governmental units to improve upon their technical and organizational capacities through training, monitoring, and evaluations. Towards attaining this goal, the service works in conjunction with the regional coordinating councils, as well as metropolitan, municipal, and district assemblies. Thus, it constitutes a pre-eminent platform for coordinating the activities of Ghana's local governments within the ambit of the public service (Local Government Service, 2013).

Another significant development with respect to regionalism in Accra was a recommendation made in the global era for the creation of an autonomous public body to ensure better coordination of development activities. This proposition, originally contained in Ghana's 1979 Constitution, was re-affirmed by a team of experts commissioned by the Government of Ghana in the 1980s. The result was the creation of the National Development Planning Commission (NDPC) in the late 1980s. However, it was not until 1992 that the establishment of this body was enshrined in Ghana's current constitutional framework (National Development Planning Commission, 2015a). The NDPC Act of 1994 (i.e. Act 479) placed this entity under the authority of the office of the nation's president. Moreover, Article 87 of Ghana's 1992 Constitution mandates the 
NDPC to make recommendations to the President of Ghana on matters relating to planning and development policy formulation (National Development Planning Commission, 2015b). The body was therefore envisaged as a one-stop place for both the design and implementation of development plans. The NDPC was also empowered to supervise and assess various development strategies at the national, regional, and local levels (National Development Planning Commission, 2015b).

The establishment of the NDPC has played an important role in promoting regional cooperation. First, this entity serves as a common "denominator" which links all the various governmental bodies (at the local, regional, and national levels) towards fashioning out common development goals. This makes inter-agency collaboration an inherent component of what is required for its successful operation. Second, the NDPC creates a platform for dialogue and deliberation on development issues by all relevant actors. Through various fora such as workshops, seminars, and committees, players such as technocrats and civil society groups are able to make their inputs towards the formulation of an overarching national development goal. Third, the NDPC has the mandate to supervise various development strategies all levels. This entails a coordinated (and hence collaborative approach) to attaining regional and national development goals.

As noted earlier, the dominance of the public sector when it comes to regionalism in Accra is evidenced by a master planning process which guides the development process. For instance, the masterplans of 1944 and 1958 were aimed at ensuring a more holistic form of development (Odame Larbi, 1996: p. 199). However, with the exception of a few places such as the Ring Road, most of the recommendations did not materialize (Odame Larbi, 1996: p. 199). Coupled with this was the fact that many plans such as 
1963-1970 Seven Year Development Plan lacked a spatial focus. Only the 1975/76 to 1979/80 development plan included recommendations for the acquisition of land meant to address housing demands (Odame Larbi, 1996: p. 200). This plan also made proposals for an institutional restructuring of the nation's planning systems through the devolution of planning responsibilities from the national government. It called for the reform of institutions such as the Survey Department, as well as the Town and Country Planning Department (Odame Larbi, 1996: p. 200). These positive recommendations notwithstanding, the plan made no reference to the promotion of collaboration or collective action among various government agencies involved in the city-region's development (Odame Larbi, 1996: pp. 200-201).

Perhaps, partly in response to some of the aforementioned regional development challenges, some positive government initiatives have emerged in the recent past. As part of its 2003 Growth and Poverty Reduction Strategy for instance, the central government in Ghana identified transportation and physical infrastructural improvements as key strategies for promoting the expansion of the economy through wealth creation. Thus, in 2008 , the government, acting in conjunction with international development partners launched the Ghana Urban Transportation Project with the goal of improving upon public commuting (Okoye et al., 2010: p. 11). Moreover, in 2010, the Ghana Shared Growth and Development Agenda was launched (in lieu of the previously existing Growth and Poverty Reduction Strategy) as the nation's "medium-term development framework" spanning 2010-2013. In connection with this new plan, the NDPC was tasked with the responsibility of overseeing the promulgation of medium-term development plans by the various metropolitan, municipal, and district assemblies in consonance with the national 
strategy (National Development Planning Commission, 2015b). Towards accomplishing these goals, the Accra Metropolitan Assembly launched a blueprint spanning 2010-2013 within the framework of the national document (Accra Metropolitan Assembly, 2013: p. 4).

\subsection{Discussion}

Towards understanding the respective approaches of Chicago and Accra to regionalism in the global era (within the framework of critical realism), the economic, political, path-dependent, and historical contexts of the two metropolitan areas must be kept in mind. In the case of Chicago, the global era resulted in an economic imperative for efficiency in inter-governmental arrangements as a way of enhancing its regional competitiveness. This has led to the springing up of bodies such as the Metropolitan Mayors' Caucus. Moreover, the promulgation of the Illinois Constitution of 1970 helped to break the tide created by the 1870 Constitution which had limited the power of home rule and made inter-local cooperation virtually impossible. These developments notwithstanding, the relatively long political culture of local autonomy has resulted in a complex web of governmental structures, each of them dealing with specific local matters. Thus, even though the proliferation of these governmental units has created serious challenges for development coordination, a path-dependent behavior which emphasizes local autonomy has meant the status quo remains largely unchanged.

In Accra, the global era with its emphasis on efficiency resulted in administrative restructuring as a way of devolving power to local authorities. The result has been the 
creation of new local governmental units by successive governments with the objective of enhancing administrative efficiency. These positive developments notwithstanding, the largely institutional nature of the reforms has meant that regionalism is steeped in bureaucracy. This situation dates back to the days of colonialism when British authorities presided over the creation of a large public sector characterized by hierarchical layers of authority. Moreover, little or no emphasis was placed on engendering citizen engagement and the entrepreneurial bent. The result was that while the public sector grew in size, the private sector was small and not well developed. This practice continued after independence, meaning that the public sector became the primary driver of national development. As a result, even though the private sector has emerged as an important development partner in the recent past, it has little or no role to play when it comes to regional cooperation in particular.

The respective approaches by Chicago and Accra to regional cooperation in the global era may also be understood in light of new regionalism. This school of thought seeks to break away from the traditional notion of government which is focused on the creation of formal institutions characterized by hierarchical layers of authority. Rather, new regionalism is underpinned by governance, which is a fluid process comprising voluntary collaborative arrangements amongst autonomous localities. It may therefore be argued that in many respects, the existence of complex networks in Chicago as regards regional cooperation is a testament to its highly-ranked position in several indices of globalization. The existence of complex networks entrenches considerable local autonomy in the global era. This is demonstrated by the largely voluntary nature of agreements, which protect local interests. These positive developments notwithstanding, 
the sheer complexity associated with the multiplicity of governmental structures raise dilemmas with respect to efficiency and the enforcement of inter-local agreements. This reinforces the argument by Norris (2001) that regional governance cannot occur in the absence of formal governmental structures. Moreover, the findings appear to suggest that Chicago has not fully realized its potential with respect to new regionalism's focus on coordination as a way of curbing the inefficiencies associated with political fragmentation.

In the case of Accra, the hierarchical and formal nature of regionalism typifies the notion of government. This correlates with its relatively lower level ranking on many indices of globalization. Thus, even though the city-region has chalked tremendous strides in the recent past with respect to democratic consolidation, globalization is still weakly linked with local autonomy. The various governmental units in Accra comprise chief executives and numerous administrative staff. In theory, this arrangement is supposed to ensure a more coordinated approach to regional development. However, bureaucratic bottlenecks mean that envisaged plans are not always attained. The hierarchical nature of regionalism in Accra may also be understood in light of institutional restructuring associated with the global era. These changes in part seek to reduce over-centralization of power through devolution. Thus, the creation of new metropolitan, municipal, and district assemblies in Accra is part of the process of empowering localities to fashion out their development goals. The findings in Accra confirm the assertion by Norris (2001) that metropolitan governance cannot take place without formal governmental structures. Moreover, the observations suggest Accra's emphasis on the creation of formal regional governmental structures is informed by new 
regionalism's focus on ensuring a more coordinated approach to the development process.

The perspectives of Swyngedouw (2004) concerning rescaling, in relation to networks and regulatory (institutional) frameworks, were confirmed by this study. In the case of Chicago, the presence of complex networks resulted in a fluid, voluntary, and informal approach to cooperation. And for Accra, an institutional imperative resulted in an administrative, directed, and formal approach to cooperation. These findings suggest that this portion of Swyngedouw's (2004) analysis was sufficiently underpinned by considerations of how local contexts mediate the implications of globalization for regionalism.

The observations made in Chicago and Accra may also be compared and contrasted with respect to the "economic logic" and "political logic," respectively. In the case of Chicago, economic logic is evident because cooperation primarily seeks to enhance the economic competitiveness of the city-region. Thus, the political process (as manifested by strong mayoral control and the presence of bodies such as the Metropolitan Mayors' Caucus) is used primarily as a tool for attaining economic goals. The emphasis on local autonomy also connotes a division of labor by various local actors with the goal of pooling economic synergies at the regional level. In the case of Accra, political logic is demonstrated by an administrative and institutional imperative which stresses the strong role of the public sector in the development process. This approach is more focused on coordination and avoiding the pursuit of helter-skelter policies. Thus, the political process is employed towards yielding collective benefits as a way of protecting the overarching 
public interest. This results in a high level of central government control, with the goal of ensuring regional efficiency.

\subsection{Summary}

To summarize, this chapter has looked at how local factors in Chicago and Accra mediate the implications of globalization for regional cooperation. It finds that Chicago practices a network approach to cooperation characterized by governance, while Accra is marked by a hierarchical or multitiered approach associated with government. The network approach is fluid, voluntary, and informal in nature; while the hierarchical approach is administrative, directed, and formal in scope. Moreover, the private sector has a strong role when it comes to regional cooperation in Chicago, while the public sector is more prominent in the case of Accra. Thus, regionalism in Chicago is based on the "economic logic" while the "political logic" reigns supreme in the case of Accra. The findings in Chicago lend credence to the assumptions contained in Sassen's global city model. In the case of Accra, the observations bring to the fore limitations in Sassen's argument. The next chapter will focus on how globalization differentially impacts rescaling in the two city-regions. 


\section{CHAPTER 6}

\section{GLOBALIZATION AND RESCALING: THE ROLES OF LOCAL FACTORS Overview}

This chapter examines the implications of globalization for rescaling in Chicago and Accra. This is important given the fact that regionalism is a form of rescaling with multiple interactions. The chapter explains differences in rescaling, as accounted for by the respective political cultures, path-dependencies, and histories of Chicago and Accra.

\subsection{Comparing Rescaling in Chicago and Accra}

Rescaling in Chicago and Accra may be compared and contrasted on a number of grounds. To begin with, governance in Chicago dates back to the days of the American Revolution when even a handful of citizens could apply for a municipal charter. Thus, even though annexation occurred initially, there has been increased opposition to this over time. The result has been a highly decentralized governmental system which emphasizes local autonomy. This situation has further entrenched the culture of mayoral politics and political fragmentation. Unlike Chicago, metropolitan governance in Accra dates back to the days of British colonial rule. Due to the relative lack of local autonomy, the city-region has expanded over the years to encompass outlying areas. Moreover, centralization and the national interest have entrenched the role of the national 
government and its bureaucratic apparatus in the governance process. The nature of rescaling in Chicago and Accra may be summarized as follows:

Table 6.1 Rescaling in Chicago and Accra

\begin{tabular}{|l|l|l|}
\hline Rescaling & Chicago & Accra \\
\hline History & $\begin{array}{l}\text { American revolutionary } \\
\text { origins }\end{array}$ & $\begin{array}{l}\text { British colonial and } \\
\text { postcolonial roots }\end{array}$ \\
\hline Areal Expanse & Resistance to annexation & Outward expansion of city \\
\hline Nature of governance & Decentralized & Centralized \\
\hline $\begin{array}{l}\text { Political/Citizen } \\
\text { interests }\end{array}$ & Local autonomy & National interest \\
\hline Political control & Mayoral politics & $\begin{array}{l}\text { Central government } \\
\text { control }\end{array}$ \\
\hline Arrangements & Fragmented & Bureaucratic \\
\hline
\end{tabular}

(Source: Author's construct based on literature, discourse analysis, and interviews)

Historically, the American Revolution made many citizens skeptical of any form of centralization as they viewed such a development as an affront to local autonomy. Local autonomy was important to citizens because of the perception that a regional government may be less forthcoming when it comes to addressing specific issues confronting localities. Thus, even though many localities in Chicago initially saw annexation as a viable way for them to enjoy better quality of services and promote governance efficiency, the desire by these jurisdictions to preserve their autonomies eventually won out. The city therefore expanded outwards at a very slow pace for much of the twentieth century.

Unlike Chicago, British colonial rule in Accra placed little or no emphasis on local autonomy due to the imperative to protect the interests of the colonial authorities. As a result, territorial expansion of the city to encompass outlying areas is quite common since this development does not have much implication for autonomous decision-making. 
Moreover, incorporation into the city limits is usually perceived by localities as a viable way for them to benefit from the synergies associated with the city-regional economy. This situation has been compounded by rapid population growth over the years, thereby heightening the pace of suburbanization. For instance, Accra has expanded over the past few decades to encompass outlying areas such as Pantang, Ashale Botwe, Agbogba, and Gbawe which were hitherto largely not regarded as part of the border limits of the cityregion.

It must also be noted that local governmental units in Chicago (within the global era) are creatures of the State Constitution. Even though Dillon's Rule initially limited the powers available to cities like Chicago, the 1970 Illinois State Constitution sought to curb this development. The implication is that the State Government of Illinois, as well as home rule which Chicago has enjoyed in the recent past, have led to the emergence of highly autonomous decision-making processes. This aligns very much with the longcherished American tradition of decentralized governance. This tradition in Chicago results in each of the various local governmental units articulating its own goals and (in many cases) controlling resources for development. For instance, special districts provide various services (such as water and education) and usually have the power of taxation as a way of raising revenues.

In the case of Accra, the 1992 Constitution of Ghana and the Local Government Act of 1993 define the legal frameworks for the existence of local governmental units. As a result, the central government still plays an important role in the governance of the metropolis. Part of this emanates from its status as a capital city-region. However, much of the centralized nature of governance in Accra has to do with the dominance of the 
public sector, as well as the fact that Ghana is a unitary, rather than a federal republic.

These factors give greater leverage to the central government when it comes to decisionmaking at the local level. The goal here lies in the need to protect the overarching national interest. This occurs by ensuring that the development strategies of lower level governmental bodies are in sync with those at the higher level.

The decentralized and autonomous nature of governance in Chicago is also evident in its mayoral politics. For much of the nineteenth century, Chicago enjoyed a weak mayor-strong council form of government. Given the fact that many of the aldermen on the council represented their respective wards, this move sought to entrench local autonomy. In the recent past, a strong mayor-weak council emerged partly as a result of the existence of the Daley machine. This machine was crucial towards ensuring regional governance efficiency through better coordination. The Democratic Party provided the political platform for the attainment of this goal. For instance, the first Mayor Daley occupied both the position of city Mayor and chairman of the Cook County Democratic Party. Moreover, the second Mayor Daley sought to win the support of prospective aldermen as a way of strengthening his powers.

Notwithstanding some tendencies towards coordination, the nature of governance in Chicago is still highly fragmented. This is evidenced by the over 1,200 units of government which dot the landscape of the city-region. The fragmented nature of governance may be explained in part by decades of mistrust between the city and suburbs, which make any form of regional government largely unfeasible. Moreover, the nature of land use planning in Illinois places emphasis on autonomous decision-making. Even though fragmentation entrenches local autonomy, the sheer number of 
governmental structures, coupled with their control of resources, creates tremendous challenges when it comes to the coordination of development activities. The result has been the pursuit of contradictory, and sometimes overlapping, development agendas.

Unlike Chicago, strong central governmental control exists when it comes to regionalism in Accra. This arrangement has the goal of protecting the overriding national interest. Accra's centralized nature of governance is manifested for instance by initiatives of mayors which are largely in sync with the wider development goals of the central government. For instance, attempts by past mayors such as Nat Nunoo Amarteifio and Stanley Nii Adjiri Blankson to decongest the Central Business District of the city were arguably conceived out of implicit central government goals of creating more livable and pedestrian-friendly environments. Moreover, the AMA's current medium-term development framework under the watch of Mayor Alfred Oko Vanderpuye, is largely in tune with the overall medium-term national development framework for 2010-2013 christened the Ghana Shared Growth and Development Agenda.

Ghana's local government reform of 1988 sought to devolve powers to local authorities as a way of reducing over-centralization of governance. However, even these reforms have compounded the problem of bureaucracy associated with centralized governance. First, they have led to the emergence of many new local governmental units, each characterized by an administrative set-up. Second, the local governments emanating from the reforms are conceived of as part of a wider hierarchical setting, encompassing local, regional, and national structures. Third, the fact that these reforms occurred within the context of a public sector-led form of development resulted in the emergence of regional government, rather than governance. 
Overall, the arguments by Brenner (1999a and 1999b) and Swyngedouw (2004), regarding upward and downward rescaling of governance associated with the global era, were confirmed in the case of Chicago. To begin with, many of the city's business leaders involved in regional efforts are chief executives or associates of global corporate entities. Moreover, the proliferation of local governmental units represents the increased devolution of power away from the national and state levels. In the case of Accra, the analyses by Brenner (1999a and 1999b) and Swyngedouw (2004) were largely not confirmed because while some administrative devolution has occurred in the global era, the central government still wields a considerable amount of power in city-regional governance. Moreover, the fact that the city's integration into the global economy is at a relatively nascent stage implies that even though supra-national actors such as global firms increasingly play important roles, their actions are still defined by the Government of Ghana. The findings appear to suggest that the analyses by Brenner (1999a and 1999b) and Swyngedouw (2004) had an Anglo-American bias and failed to sufficiently account for the role of local contexts, particularly in the Global South, when it comes to the nature of rescaling associated with globalization.

\subsection{Rescaling in Chicago}

Given the focus of this chapter, rescaling in Chicago will be discussed in detail with respect to: American revolutionary origins and annexation, decentralization and local autonomy, mayoral politics, and political fragmentation in the global era. 


\subsubsection{American Revolutionary Origins and Annexation}

In the 1700s and 1800s, the United Kingdom and many other nations in Europe were characterized by considerable centralization of power. The situation was however different in the United States as the ground-breaking nature associated with the American Revolution (and hence the nation's political liberation) meant that many citizens were not in favor of consolidation. Moreover, legal antecedence meant that even a handful of people residing in a particular place could declare their area as a settlement (Orum, 2005). This was the case for Chicago in 1837, when a group of ordinary citizens who resided in this area, applied to the Illinois legislature for their locality to be formally recognized as such. Their application received a favorable response, resulting in the award of a legal charter which granted them the right to have their own governmental and decision-making structures, as well as the power to raise revenues (Orum, 2005). In the ensuing decades, particularly between the 1860s and 1900s, Chicago's population increased significantly from 112,172 to $1,698,575$. This development, coupled with rail lines which led outwards from the central city to surrounding areas, resulted in an increased pace of suburbanization. As a result, the city of Chicago sought to annex neighboring jurisdictions in order to promote regional efficiency (Orum, 2005).

As of the late 1800 s, annexation became important due to the rise in costs associated with service delivery in cities. These higher costs occurred as a result of greater demand associated with rising population numbers and technological advancements. Territorial expansion was perceived as a viable way of addressing the service delivery needs of localities because larger-sized municipalities enjoyed economies of scale in providing services (Cain, 2005). Besides, they had the economic 
and political clout to raise extra funds (when the need arose) to fund such services. Suburbs were constrained in the provision of such services by their relatively small population sizes (which led to cost inefficiencies), as well as the legal cap on the debt levels they could accrue. Thus, they opted to be annexed by Chicago in order to enjoy the same services as city residents. For instance, Lake View Township opted for this mechanism so that it could experience an improvement in its waste water disposal system (Cain, 2005).

Over the course of time however, many of these suburban towns and villages became increasingly resistant to annexation as they began to see autonomy as the best way of escaping the ills of city life. These included poverty and the bureaucratic apparatus associated with large city government (Teaford, 2005). Moreover, as a result of the focus of metropolitan authorities on matters mostly affecting the city of Chicago, local autonomy was perceived as the most effective way of catering to the pressing economic and social needs of suburban communities. For instance, some communities which saw employment creation as a priority used their autonomy to promote the creation of manufacturing enclaves within their borders. Other jurisdictions also took the opportunity to improve their governmental systems through the hiring of the services of skilled administrators (Teaford, 2005).

Moreover, local autonomy was paramount because given the appreciable improvements in the quality of suburban service delivery as of this time, suburbanites did not feel they had much to gain from being incorporated within the city's boundaries. As already noted, many suburbs had earlier opted to be part of the city of Chicago so that they could benefit from the same services residents enjoyed. Over the course of time 
however, increased suburban populations meant that these jurisdictions were also able to provide such services with relative cost efficiency (Teaford, 2005). Moreover, the unique service needs of some of these suburbs implied that sometimes, the creation of special districts, rather than annexation, held the key to improving upon the quality of service delivery. For instance, the promulgation of the "Sanitary District Enabling Act of 1889" led to the emergence of new local governmental units and made it possible for suburbs within designated jurisdictions to enjoy waste disposal services (Cain, 2005).

As a result of the aforementioned reasons, only a handful of territories, such as those around the O'Hare International Airport, were incorporated into the city's boundaries in the twentieth century (Bennett, 2006: p. 278). Specifically, between the 1920s and 1950s, not more than 20 square miles of land were annexed by the city of Chicago. This led to the springing up of many small governmental units across the metropolitan landscape. For instance, over 1,000 units of government could be identified as of the 1930s. These included township governments for places like Evanston characterized by record low population densities. At the same time, there was the proliferation of special districts to address the needs of residents within the ever-growing sub-urban counties (Orum, 2005).

\subsubsection{Decentralization and Local Autonomy}

Like many American metropolitan areas, Chicago's governmental structure is greatly decentralized. In the 1800 s, when Illinois was regarded as America's western frontier, various small and separate governmental units were created to promote some 
level of sub-regional governance as a way of protecting local autonomy. Currently, there are greater levels of regional inter-connectivity because of improvements in mobility and growth in townships. These developments notwithstanding, the various regional actors still do not really possess the powers to promote regional governance as a result of the autonomous nature of the decision-making process. Thus, even though some annexations have occurred over the years, the tendency towards decentralized governance remains strong. Chicago's form of government traditionally comprises a council and mayor (originally created in 1837), with the council wielding considerable authority. In 1875, the "City Council" came to replace the "Common Council" associated with the 1837 legislation (Mayfield, 2005). Wards in various parts of the city choose members of the council and define how public services are provided. This practice serves to further entrench the devolution of power (Mayfield, 2005).

The nature of metropolitan governance in Chicago may therefore be explained by the fact that the city-region is divided into 50 districts referred to as wards, with an alderman articulating the concerns of each of these wards at the City Council. Due to the focus of aldermen on predominantly local issues, they appear less concerned with regional matters (Zhang, 2013: p. 76). Moreover, each alderman possesses the power to reject decisions made at the City Council concerning the ward he/she represents. If such a situation occurs, the alderman has the final say, a situation referred to as "aldermanic prerogative or privilege" (Zhang, 2013: p. 76). While this situation ensures local autonomy, it also heightens the fragmented nature of political decision-making in the metropolitan area. Between the 1850s and 1930s for instance, the mayor of Chicago had much fewer powers than the City Council. As a result, various aldermen exercised 
considerable control over their wards when it came to deliberations at the council (Zhang, 2013: p. 76).

The nature of metro governance in Chicago is also attributable to the divide which exists between the city and suburbs. There was a time when the city had more people than the suburbs and was therefore the heartbeat of the regional economy. Currently however, the suburbs have more people than the city; and this creates tensions as to where the real center of the economy is. Moreover, due to the large number of governmental structures and the fact that they wish to protect their individual interests, they are usually reluctant to participate in any form of regional governance. Also, multiple tensions occur between the central city and the suburbs with respect to funding decisions and population distribution. To cite an example, perception is rife among suburbanites that the central city gets an unfair share of resources. The city is also reluctant to cede available powers. Moreover, tensions exist between the city and suburbs on the one hand, and the rest of the state of Illinois (which primarily relies on agriculture for its economic subsistence) on the other hand. It is also important to note that even though suburbs have grown in size over the years, the multiplicity of existing governmental structures make it difficult for them to speak with a common voice, particularly when it comes to regional matters.

The nature of metro governance also has constitutional and political origins. Due to the culture of strong local autonomy in the United States, local governments are in many cases, creatures of state constitutions; and the situation in Chicago is no exception. Specifically, two types of government exist namely: home rule and non-home-rule. These various governmental units enjoy considerable autonomy, particularly in the case of 
home rule. Prior to the 1970s, the various local governmental units in the city-region derived their powers from the 1868 ruling of Justice F. Dillon which granted state governments the final say in local matters. Since the birthing of localities was derived from state law, Dillon's Rule accorded states the leverage to determine the powers available to these local governments at any point in time. Thus, even when cities such as Chicago began to expand at the beginning of the 19th century, the Illinois State Legislature refused to grant them the power of home rule (Orum, 2005). After the promulgation of the 1970 Constitution however, many of these local governmental units came to enjoy home rule.

\subsubsection{Mayoral Politics}

As noted earlier, the charter of the city of Chicago promotes a weak mayor-strong council form of government. This is perceived as a practical way of entrenching the long cherished American tradition of local autonomy. Because many local governmental units are reluctant to partake in any form of regional government, a weak mayor-strong council arrangement is regarded as being paramount to protecting local interests, while ensuring at the same time that pressing regional issues are effectively dealt with. Moreover, such an arrangement is crucial to promoting democratic engagement through the pooling of ideas by various local officials on the city council. Since officials on the council speak on behalf of their respective wards, this form of government is believed to entrench the ethos of representative democracy. 
Even though mayors in Chicago traditionally had few powers, they have assumed more controls over the years. Perhaps, the genesis of this was the increase (during the $1860 \mathrm{~s}$ and 1900s) in the length of time a mayor stayed at post. Moreover, reforms adopted by the State of Illinois in 1995 resulted in a change from the previously existing party-based model to the current system not based on political affiliations (Mayfield, 2005). Over the course of the 1800 s, the mayor largely played a supervisory role, particularly when it came to the proceedings at the city council. However, this began to change, as he increasingly assumed powers such as veto and the nomination of commission members. The mayor did not have much decision-making authority though, as the city council controlled local budgeting and the various departments retained considerable autonomy (Mayfield, 2005). The fragmented nature of Chicago's governance structure therefore served as a major obstacle to those who believed regional solutions were key to dealing with pressing issues. Moreover, private individuals and groups bent on serving their own interests managed to by-pass these systems and influence the policy formulation process. For instance, these private actors sought to actualize Daniel Burnham's development plan for the city by putting together an entity known as the Chicago Plan Commission (Mayfield, 2005).

In response to the highly fragmented nature of the governance process, the emergence of the "Chicago political machine," spearheaded by three successive mayors, helped to ensure coordination, even if not formally. These mayors included Anton J. Cermak, Edward J. Kelly, and Richard J. Daley, who governed between the 1930s and 1970s. For instance, Mayor Daley, who was in office from 1955 to 1976, sought to assert his powers in city council deliberations by taking charge of ward- affiliated bodies 
involved with the Democratic Party (Mayfield, 2005). Moreover, a decision by the Illinois State legislature resulted in the mayor, rather than the city council, taking the lead when it came to budgeting matters. Other legislation led to an increase in the level of control exercised by the mayor over city departments (Mayfield, 2005). Subsequent mayors such as Jane M. Byrne and Harold Washington were less successful in their attempts to consolidate power. To cite an example, political bickering by opponents at the city council led to gridlock during the first three years of Harold Washington's term in office. However, Richard M. Daley managed to consolidate some power by employing fundraising and other mechanisms to woo prospective aldermen to his side (Mayfield, 2005).

Thus, the increase in the powers of the mayor in the recent past may be attributed to the pressing need to curb excessive governmental fragmentation as a way of enhancing regional efficiency. Besides, a strong mayor helps to pool various local initiatives towards fostering a regional agenda, with the ultimate goal of enhancing the competitive edge of the city-region. It is important to note that while the mayor of Chicago is weak on paper, political developments (especially within the Democratic Party) in the recent past have made it possible for him to increase his powers. For instance, Mayor Richard Daley assumed greater powers by occupying both the positions of city Mayor and Cook County party chairman. As a result of these recent developments, a strong mayor-weak council form of government has developed. The mayor's powers may therefore be perceived as being second only to that of the governor of the State of Illinois.

Notwithstanding the fact that the Daley political machine led to some level of coordination, the nature of metro governance in Chicago still remains highly fragmented. 
This occurred partly because the Daley machine encouraged coordination only in so far as it furthered the course of the private sector (Ferman, 1996: p. 55). For instance, the planning process in Chicago during this time period became a largely private endeavor, as manifested in the promulgation of the 1958 Development Plan by the Chicago Central Area Committee. Daley supported these private efforts by providing requisite physical infrastructure and other concessions (Ferman, 1996: p. 59). Besides the private nature of the planning process, autonomy was typified by the 50 wards represented on the city council, resulting in the furthering of largely local interests. Moreover, the lack of a formal institutional arrangement with respect to regionalism meant that coordination was highly dependent on the continuous existence of the Daley machine (Ferman, 1996: p. $55)$.

\subsubsection{Political Fragmentation in the Global Era}

As of the late 1990s, over 1,200 different bodies could be identified in Chicago's governmental set-up. These comprised special districts dealing with specific local concerns, as well as structures at the county, municipal, and other levels (Great Cities Institute, 2001: p. 8; Lindstrom, 1999). Currently, Cook County alone has 540 of such bodies attending to various local matters. Each of the governmental units in the county raises revenues through tax assessments (Simpson, 2006: p. 8). Meanwhile, seven distinct local authorities impose taxes on residents of the inner city; and suburban residents are levied by 17 different governmental bodies. In many respects, this multiplicity of governments represents an arrangement more suited for the 1800 s when many of them first sprang up. This is due to the fact that it is not cost-effective and creates tremendous 
challenges when it comes to ensuring an orderly development process (Simpson, 2006: p. 8).

While the fragmented nature of Chicago's political landscape is aimed in part at enhancing citizen engagement, the reality is that it affects the legitimacy and feasibility of the electoral process. For instance, there are too many choices to make during local elections and this stymies voter interest. Specifically, when it comes to elections for judges, voters sometimes have to answer as many as 200 questions and this proves to be an impossible task. There are also elections for county boards, water reclamation districts, and many other local governmental units. These developments make the democratic process ineffectual because it becomes difficult to know whom to vote for; and this portends negatively for public accountability. Moreover, the various governmental units control financial and employment resources; and these result in patronage issues. The status quo has been entrenched by the fact that no strong case has been made by public officials about the costs associated with the lack of a regional government.

One major factor which accounts for the fragmented nature of governance in Chicago is the autonomous nature of land use regulations in the metropolitan region (Great Cities Institute, 2001: p. 8). In Illinois, just like other parts of the United Sates, the state government grants localities considerable powers with respect to zoning and other mechanisms (Great Cities Institute, 2001: p. 8). These powers make it difficult to create any form of regional government as localities fear that doing so will cause them to lose their autonomies. Moreover, strategies and decisions at the state level have played considerable roles in accounting for the springing up of numerous structures of 
government. For instance, the relatively limited powers available to municipalities with respect to taxation result in the emergence of special districts. These districts, unlike many municipalities, are able to raise revenues through taxes and bonds, in order to offer quality services to residents (Great Cities Institute, 2001: p. 8).

Between the 1950s and 1990s, regional planning in the Chicago metropolitan area was largely carried out under the auspices of the Chicago Area Transportation Study (CATS) and the Northern Illinois Planning Commission (NIPC). In many respects, the planning responsibilities for these two bodies were overlapping, resulting in regional inefficiency (Johnson, 1999: p. 48). CATS devised an ambitious target for regional growth, which proved largely elusive, due to the lack of a comprehensive plan for the wider region. Moreover, CATS upon its initial establishment was responsible for landuse planning in only about a third of the metropolitan area. Coupled with this were the challenges faced by the body in terms of resource availability (Johnson, 1999: p. 48). Even as CATS was faced with these challenges, the problems encountered by NIPC were no easier. For instance, this body had to grapple with tremendous resource challenges, thereby hampering the effectiveness of its work (Johnson, 1999: p. 49). Moreover, NIPC's activities relied on the financial largesse of local authorities, causing them to have a great influence on the formulation of its plans (Great Cities Institute, 2001: p. 9; Lindstrom, 1999). Following concerns about the overlapping responsibilities of CATS and NIPC, the two bodies were merged in 2005 to create the Chicago Metropolitan Agency for Planning (CMAP). This positive development notwithstanding, Chicago still lacks a regional government; and the nature of governance is highly fragmented. 
Essentially, the Regional Transportation Authority (RTA) is the only public entity in the Chicago Metropolitan area. This is because the body was originally envisioned both as a "special purpose unit of local government and a municipal corporation of the state of Illinois" (Regional Transportation Authority, 2014). The authority was created through a vote by the six counties in the Chicago city-region, as a way of dealing with revenue shortfalls experienced by the Chicago Transit Authority, as well as the suburban bus and rail services. However, the elections which resulted in the creation of the body exhibited the divide in Chicago city-suburban politics as city residents voted overwhelmingly in support while those in the suburbs voted against it (Lindstrom, 2014). Moreover, during another funding challenge in 1983, the RTA Act was amended, thereby restricting its role to monitoring budgets and funds associated with the operation of transit systems in the city-region. The Act split up the RTA into three main branches: Chicago Transit Authority, Pace suburban bus, and Metra rail (Lindstrom, 2014; RTA, 2014). These moves sought to create a workable solution for all the various interested parties (i.e. city residents and suburban actors) in the region's transportation system. As a result, what was originally envisioned as a unitary transportation system has become an archetype of fragmentation (Lindstrom, 2014).

Generally speaking therefore, the fragmented nature of governance in Chicago is demonstrated by the lack of a central governmental authority for the city-region. Even though some regional governmental structures exist, they lack the power to enforce their decisions. To begin with, the Metropolitan Mayors Caucus seeks to promote cooperation between city and suburban mayors, but does not have "police power." Moreover, CMAP strives to promote cooperation, but does not have the power of enforcement. For instance, 
while CMAP has taken the lead in initiating policies such as the Water 2050 (a regional plan for water supply), it has no control over funding and infrastructural arrangements necessary for this plan to work out in practice. Also, the RTA makes various transportation plans for the metro area, but lacks the power of enforcement in terms of control of train stations. Thus, what prevails are counties or municipalities which make localized decisions and sometimes decide to cooperate if they deem it fit to do so.

\subsection{Rescaling in Accra}

Given the focus of this chapter, metropolitan governance in Accra will be discussed with respect to: British colonial/postcolonial origins and territorial expansion, centralization and the national interest, central government control, as well as bureaucracy in the global era.

\subsubsection{British Colonial/Postcolonial Origins and Territorial Expansion}

The origins of centralized planning in Ghana dates back to the days of colonial rule when various development plans were put in place with little or no input from ordinary citizens. This was aimed at speeding up national development, while ensuring at the same time that the colonialists did not lose their grip on power (Frimpong Boamah and Amoako, 2013: pp. 146-147). Between 1920 and 1930 for instance, a development plan was launched by Governor Guggisberg in the then Gold Coast (Ewusi, 1973: p. 1). This plan was created with the goal of promoting economic and social development mostly through investments in infrastructure (Ewusi, 1973: pp. 11-12). Several other 
development plans followed the one put together by Guggisberg. These included the following: "Plan of Development and Welfare for the Gold Coast" from 1946 to 1956; "Plan for the Economic and Social Development of the Gold Coast" spanning 1951 to 1961; “The First Five-Year Development Plan” from 1951 to 1956; "The Consolidation Plan" between 1958 and 1959; "The Second Development Plan" from 1959 to 1964; and “The Seven Year Development Plan” spanning 1964 to 1970 (Ewusi, 1973: p. 1). The overarching goal of these various plans was to ensure a coordinated approach to the development process.

Towards strengthening the hand of the colonial authorities in the governance process, the period between 1852 and 1940 also saw the exclusion of traditional leaders from the various local government structures. This practice was entrenched in 1951 following the promulgation of the Local Government Act. The act created two new layers of local government, namely "District Councils" and "Local Councils," which left traditional leaders out of the decision-making process (Frimpong Boamah and Amoako, 2013: p. 147). In many cases, traditional authorities embodied the development aspirations of their communities; and so excluding them from the decision-making process had negative ramifications for local development and citizen engagement. For instance, since much of the land ownership was vested in the hands of these leaders, their exclusion had negative ramifications for land-use planning. Admittedly, the case can be made that a semblance of autonomy existed in the form of the system of indirect rule, mostly carried out by colonial authorities via chiefs and other local authorities (Awortwi, 2011: p. 356; Haruna, 2004: pp. 196-197). However, this mechanism was adopted only to 
the extent that it furthered the interests of the colonial authorities. Besides, indirect rule was a top-down, rather than a bottom-up governance mechanism.

Partly as a result of the non-incorporation of traditional leaders in the planning process, urban planning in Accra during the colonial era was concentrated in the European settled areas to the virtual exclusion of neighborhoods inhabited by indigenes. Thus, the development of these European areas such as Ridge and Cantonments proceeded in a planned and controlled manner, whereas other suburbs expanded in an uncontrolled manner (Odame Larbi, 1996: p. 198). Moreover, colonial authorities forcibly acquired land from traditional leaders only when it was in furtherance of this goal. This led to the emergence of both a state-owned and traditional system of land ownership. In the areas where land was administered by traditional leaders, clearly designated planning mechanisms were largely lacking (Odame Larbi, 1996: p. 198). The rapid growth of Accra in the colonial era was therefore attributable in part to the lack of a designated urban growth boundary in indigenous areas which led to the continuous expansion of the city, particularly along transportation routes.

The outward expansion of Accra during the days of colonialism was also facilitated by the fact that as far back as this time, local autonomy was largely lacking in this city-region and many other parts of the country. It may be argued that some form of decentralization occurred before 1946 since Ghana at this point in time comprised four territorial domains - namely the Gold Coast, Ashanti, the Northern Territory, and British Togoland - run as separate political entities by the British (Awortwi, 2011: p. 356; Haruna, 2004: p. 197). However, it must be kept in mind that even though these territories were governed as separate entities, this was done with little or no input from 
local communities. Besides, from 1946 onwards, the British began to administer the four territories as a single political entity, thus heightening the centralization of power. This system of administration continued till 1957, when Ghana attained political independence (Awortwi, 2011: p. 356). It may therefore be argued that the outward expansion of Accra to encompass outlying areas during the colonial era was feasible because this move was not perceived by the territories in question as an affront to their self-determination (which was non-existent to begin with).

After independence, the Nkrumah government continued with the modes of planning adopted in the colonial era due to low levels of technical capacity and the focus on other pressing development challenges (Ewusi, 1973: pp. 5-6). These factors, coupled with the pursuit of a socialist agenda meant that the centralization of power continued, resulting in a largely public-sector led form of development. The enabling environment was therefore created for the outward expansion of the city as localities did not stand to lose any autonomy by being incorporated in its borders. Moreover, there were increased investments in Accra by the Nkrumah government so that the metropolitan area would assume a status befitting a capital city-region for a modern nation (Konadu-Agyemang, 2001: p. 67). Specifically, infrastructural investments such as roads and hospitals were prominent. Besides, there was an ambitious industrialization drive, resulting in the springing up of new commercial entities (Konadu-Agyemang, 2001; p. 67). The period also witnessed the establishment of many ministries, departments, and agencies in Accra, thus attracting various skilled professionals to locate in this metropolitan area. As a result of these developments, the city-region's population increased from 288,300 in 1957 to 338,000 as of 1960 (Konadu-Agyemang, 2001: p. 67). This further rose to: 564,000 in 
1970 and 1.8 million in 1998 (Konadu-Agyemang, 2001: pp. $67 \&$ 69). Moreover, as of 1997, Accra's land area had increased more than three-fold in relation to what it was in 1975. Much of this growth occurred on the periphery of the city-region due to the uncontrolled expansion of the metropolitan area to encompass outlying rural areas (Yeboah, 2000: pp. 68-70).

\subsubsection{Centralization and the National Interest}

As far back as the latter part of the 1940s, the need for the devolution of power was clear, as contained in reports by the Watson Commission (1948) and the Coussey Committee (1949). While Watson called for the creation of regional councils, Coussey advocated for autonomous regional administrations (Haynes, 1991: p. 284). These recommendations were upheld by the Phillipson Commission of 1951 and the Greenwood Commission of 1956. The various reports recognized that some form of "decentralization" was necessary as a way of sharing power between the national government and regional/local authorities. This was paramount towards reducing central government bureaucracy (Haynes, 1991: p. 284). The proposals were however not adopted by the government of Kwame Nkrumah at the time of independence on the grounds that they could create separatist tendencies in the newly-independent nation. Moreover, centralization was perceived as being crucial towards engendering a common national development agenda (Haynes, 1991: p. 284). As a result, Ghana opted for a unitary, rather than a federal system of government, which would determine the nature of governance in the country many decades afterwards. 
In the period 1959-1960, the orientation towards centralization was evident as Nkrumah's government slashed the number of local governmental units from 252 to 69 . This was aimed at enhancing administrative efficiency and ensuring that these governmental units had sufficient resources to finance their development goals (Schiffer, 1970: p. 73). Even when the number of local councils was increased to 155 in the year 1962 , this was not necessarily aimed at devolving power to localities. Rather, it was a move to satisfy CPP grassroots activists who were clamoring for this arrangement as a way of entrenching their political foothold at the local level (Schiffer, 1970: p. 73). Also, when the number of local councils was again increased to 183 in 1965 , the fact that much of the change was evident in the creation of new administrative structures meant that local autonomy was not the goal (Schiffer, 1970: p. 73). Moreover, centralization was heightened following the adoption of the one-party system by Nkrumah in 1964. This move was ostensibly aimed at reducing political rancor and engendering a common vision for national development. However, it heightened political divisions and resulted in an increased clamor for change amidst deteriorating economic conditions. In 1966, the military overthrew the government of Kwame Nkrumah in response to the adoption of the one-party system and a declining economy (Agyeman-Duah, 1987: p. 616).

Following the CPP's demise from power, the military government of the National Liberation Council (NLC) sought to consolidate power by cutting down the number of local governmental units and assigning District Administrative Officers to oversee their operations (Haynes, 1991: p. 284). These measures were adopted with the goal of reducing the influence of the CPP in local politics so that the new government would be able to establish itself more firmly (Haynes, 1991: p. 284). At the same time however, the 
NLC government established several commissions to make recommendations for a more comprehensive reform of the nation's local government system (Haynes, 1991: p. 285; Haruna, 2004: p. 197). The various commissions made proposals for the creation of four layers of government comprising: the central government, regional authorities, "District and Local Councils," as well as "Town and Village Development Committees" (Haynes, 1991: p. 285). These recommendations sought to reduce over-centralization by establishing structures for administrative devolution. Even though the proposals were enshrined in the 1969 Constitution towards returning the country to democratic rule, the Progress Party (PP) government, led by Kofi Abrefa Busia, continued with the centralization which had started during Nkrumah's time. This was because it wanted to reduce political rancor and build grassroots support towards enabling it to implement its policies at the local level. For instance, it exercised great control over the District Councils as a way of strengthening its support base at the district level (Haynes, 1991: p. 286).

Notwithstanding the general trends towards centralization, it is important to note that between 1957 and the 1970s, various governments embarked on administrative devolution as a way of reducing government bureaucracy and making public service delivery more widely available at the sub-national level. This devolution occurred through the establishment of agencies for various central government ministries in regions and localities across the country (Awortwi, 2011: pp. 356). These agencies dealt with matters relating to the national government at the regional and local levels, particularly in relation to the provision of public services such as education, sanitation, energy, and infrastructure (Awortwi, 2011: pp. 356-357). At the same time, local councils 
were put in place to address predominantly local concerns. However, the respective functions of the central government agencies and local councils were not always clearly defined, thus creating tensions between the two bodies (Awortwi, 2011: p. 357). Towards reducing the acrimonious relations at the local level between deconcentrated central government agencies and local councils, the military government of the National Redemption Council (NRC) merged the two separate bodies in 1974 and rechristened them as "district councils" (Awortwi, 2011: p. 357). This new arrangement also had the goal of creating a more unified mode of public service delivery. This further heightened the centralization of governance as much of the power necessary for these district councils to carry out their activities was vested in the hands of administrators appointed by the central government (Awortwi, 2011: p. 357).

In 1982, the Provisional National Defense Council (PNDC) government under Jerry John Rawlings launched a new blueprint for devolving power to localities. The goal was to entrench local democracy, enhance administrative efficiency, and improve relations between the central government and local authorities (Mohan, 1996a: pp. 8081). However, this devolution also turned out to be largely administrative in nature as it merely involved the reassignment of 86 central government responsibilities such as formulation of development strategies and public service provision to local councils (Awortwi, 2011: p. 358). Further changes occurred in 1987 when 45 additional local governmental units were created, thereby increasing the number of local councils from 65 to 110 (Mohan, 1996a: p. 82; Awortwi, 2011: pp. 358-359; Danso, 1991: p. 128). Moreover, regional councils were put in place to oversee the activities of the local councils, while sub-district structures of government such as zonal councils and unit 
committees were also created (Awortwi, 2011: p. 359; Danso, 1991: pp. 127-128). These moves sought to regain the political edge of the military government, which had begun to decline at this point in time (Awortwi, 2011: pp. 358-359). In the latter part of 1988, the birthing of PNDC Law 207 resulted in the formation of metropolitan, municipal, and district assemblies as a way of enhancing grassroots involvement in the governance process (Ayee, 1996: p. 32). Moreover, this administrative devolution was a useful first step towards the eventual return of Ghana to democratic rule in the early 1990s. The newly created assemblies had executive, legislative, and deliberative arms. Their responsibilities included local budgeting, soliciting funds for development, and providing physical infrastructural facilities at the local level. They were also in charge of service provision and maintenance, public safety, and sanitation (Ayee, 1996: p. 33).

\subsubsection{Central Government Control}

Notwithstanding the gains made by Ghana in the recent past towards the devolution of power, a high degree of central government control still exists. This is because, much of the transfer of power associated with this process has been merely administrative in nature, a situation which gives the central government the biggest say when it comes to local development matters. Historically, many national leaders perceive localities as the fronts where they can implement their development agendas as a way of shoring up their grassroots support bases. Thus, they are reluctant to cede their powers to these local governments as a result of the possibility that they could become strongholds for the opposition. Moreover, local governmental units in Ghana are perceived as agents of national development, rather than platforms for autonomous decision-making. Thus, 
central government control comes across as an inherent part of the process of implementing national development goals at this scale.

Even through some level of "political decentralization" occurred as a result of Ghana's local government reform of 1988 which led to the election of members of the various assemblies, much of this supposed transfer of power was piecemeal in nature. This was because while two-thirds of the members of the various metropolitan, municipal, and district assemblies were chosen through non-partisan elections, the remaining one-third was appointed by the central government. This arrangement, which continues to this day, helps to reinforce the influence of the government when it comes to the formulation and implementation of development strategies at the local level (Mohan, 1996a: p. 84). Moreover, the chief executive of each assembly is directly nominated by the nation's president, albeit subject to the approval of not less than two-thirds of assembly members (Owusu, 2009: p. 61). The direct nomination of the chief executives of these assemblies by the president is aimed at ensuring the implementation of an overarching national development agenda across the whole country. As a result of this arrangement, the chief executives of the various metropolitan, municipal, and district assemblies (within Accra and elsewhere around the country) tend to be affiliated with the ruling party at any point in time.

Besides the direct nomination of metropolitan, municipal, and district chief executives by the central government, many of the sub-units of government which were originally envisaged as being crucial for successful administrative devolution either performed below par or were not established at all in the first place. These include "zonal councils" and "unit committees" (Nyendu, 2012: p. 228). The poor performance of these 
sub-district structures of government was due to the fact that the technical and other resource capacities needed at the local level for their successful operation were largely lacking. Moreover, the non-establishment of some of these sub-units was due in part to a lack of political will by the central government to fully carry through the components of its devolution policy (Nyendu, 2012: p. 228). This was because the path-dependency of centralization which had been followed for decades was still dictating the operational ethos of the government.

Central government control is also evident when it comes to the sources of funding for the activities of these various local governmental units. Theoretically, the assemblies operate through internally- and externally-generated funding sources. This arrangement emerged due to "fiscal decentralization" introduced as part of Ghana's local government reform of 1988. However, the internal revenue sources (namely property taxes, market tolls and fees, operating licenses and other mechanisms) are usually small and insufficient, implying that the bulk of the funding for their activities comes from central government coffers. This further heightens the issue of centralization of power, as the government can use the provision of funds as a bargaining chip to get its agenda implemented at the local level (Nyendu, 2012: p. 228). Moreover, the fact that localities continuously look up to the central government for money to finance their development plans means that they have not imbibed the concept of local autonomy in their operational ethos.

With specific reference to the Greater Accra Metropolitan Area, 53\% of funds generated by the Accra Metropolitan Assembly (AMA) come from the coffers of the Government of Ghana. Thus, only $47 \%$ of resources are raised through internal 
mechanisms. To cite another example, $25 \%$ of the AMA's revenues comprise central government subventions to the Accra Metro Roads Department. As a result, the AMA and other assemblies have limited financial independence, making their activities highly dependent on what happens at the national level (Ministry of Local Government \& Rural Development and Maks Publications \& Media Services, 2006). This situation has been compounded by the fact due to the legal context within which the AMA operates (i.e. as a promoter of development), it perceives many feasible fund-raising mechanisms as being profit-making in nature. As a result of its belief that profit-making ventures should be the preserve of the private sector, the assembly is more focused on raising internal revenues through property taxes, licenses, and fees (Ministry of Local Government \& Rural Development and Maks Publications \& Media Services, 2006).

In the recent past, the centralized nature of metro governance in Accra is evidenced by Ghana’s new “decentralization policy framework of 2010” which defined devolution of power in terms of hierarchical layers comprising national, regional, district, and sub-district levels (Government of Ghana - Ministry of Local Government and Rural Development, 2010: pp. 16-18). For instance, regional coordination councils are perceived in the nation's revised policy document not as autonomous public entities, but rather "an extension of national level institutions" (Government of Ghana - Ministry of Local Government and Rural Development, 2010: p. 16). Thus, these councils merely play coordinating and mediating roles between the activities of the central government and local authorities (Government of Ghana - Ministry of Local Government and Rural Development, 2010: p. 16). Moreover, the new document also underscored the need for the creation of an "Inter-Ministerial Coordinating Committee" as a way of dealing with 
coordinating challenges involved in the implementation of the policy (Government of Ghana - Ministry of Local Government and Rural Development, 2010: p. 31).

Overall, political and historical factors primarily account for the nature of metropolitan governance in Accra. Politically, the fact that Ghana is a unitary, rather than a federal republic means that development endeavors are carried out within national, rather than regional or local contexts. Thus, the central government plays a leading role when it comes to development in the Greater Accra metropolitan area. This situation has been reinforced by the fact that Accra is a capital city-region, a situation which has resulted in the concentration of many central government institutions in the metropolis. Moreover, the nation's practice of an executive presidential system vests many powers in the hands of the president, thereby giving him considerable leverage when it comes to matters of local development. Also, local governance is historically conceptualized as an extension of national level governance, rather than a platform for the visioning and implementation of development goals at the local level. As a result, even when development plans are put in place at the local level, they are usually carried out with considerable central government input or in fulfillment of certain national level requirements.

The high level of central government control in Accra may also be explained by systemic weaknesses present in many local government institutions (at least when compared to what prevails at the national level). As a result, the transfer of central government powers to these local institutions can have negative implications for public accountability, if the process is not well thought through. For instance, even with the current level of central government control, many metropolitan, municipal, and district 
assemblies in Ghana have earned a reputation for corruption and conflict of interest, especially when it comes to the award of contracts for road construction and other infrastructural development projects. These problems have been compounded by the relatively low levels of citizen interest and political oversight in what goes on in these assemblies, thus compounding challenges with respect to the promotion of public accountability. It may therefore be argued that the unwillingness of the central government to cede more powers to local governmental authorities is ultimately a strategy for protecting the public interest through the cutting down on potential avenues for graft.

\subsubsection{Bureaucracy in the Global Era}

Ghana's local government reform of 1988 largely conceptualizes metropolitan governance as a bureaucracy comprising several layers or hierarchies of authority. This is aimed at ensuring a more coordinated approach to local development. Moreover, bureaucracy helps to institutionalize central government control over development at the local level. The bureaucratic set-up of each metropolitan, municipal, or district assembly comprises an executive committee made up of two sub-layers: one in charge of planning, programming, and budgeting; and the other responsible for administration (Mohan, 1996b: pp. 440-441). The sub-division in charge of planning, programming, and budgeting comprises sub-committees which deal with matters relating to economic development, social services, and technical infrastructure. Moreover, the administrative unit has sub-committees with responsibilities for administration, finance, justice, and

public safety. Each of these sub-committees also consists of departments in charge of the 
various aforementioned areas (Mohan, 1996b: pp. 440-441). The executive committee for each assembly is chaired by the metropolitan, municipal, or district chief executive, with the coordinating director heading the bureaucratic apparatus.

With specific reference to the Greater Accra Metropolitan Area, bureaucracy is evident in the many hierarchical layers associated with the AMA, TMA, and other local governmental units in the city-region. As already noted, such an arrangement ensures development coordination and entrenches the role of the central government in local development. For instance, the AMA comprises a general administration which serves to coordinate the operations of all the various units and agencies under the assembly. This arrangement comprises offices for the chief executive, as well the metropolitan coordinating director and head of administration (Ministry of Local Government \& Rural Development and Maks Publications \& Media Services, 2006). There are also divisions in charge of client services, personnel, transportation, records keeping, and marriage registration. Moreover, the AMA comprises separate departments with responsibilities for: planning, treasury, education, public health, sanitation, agriculture, public infrastructure, security, internal audit and external audit, budgeting, and public relations. In addition, the Town and Country Planning Department and the National Disaster Management Organization have departments and agencies under the authority of this assembly. The AMA also consists of sub-metropolitan layers of government. These include Ashiedu Keteke, Ablekuma, Ayawaso, and Kpeshi Sub-metros (Ministry of Local Government \& Rural Development and Maks Publications \& Media Services, 2006). 
The bureaucratic nature of many local governmental units in Accra and elsewhere around the country was obvious in the early days of Ghana's local government reform of 1988. This was because 22 units and agencies of the central government operating at the local level were placed under the authority of the relevant metropolitan, municipal, or district assemblies (Ayee, 1997: p. 42). This was meant to devolve powers to the local authorities so that they could effectively preside over the provision of services, carried out by the departments and agencies in question (Ayee, 1997: p. 42). Towards actualizing this goal, budgetary allocations to these decentralized bodies were to be channeled through the metropolitan, municipal, and district assemblies in order to increase their supervisory roles over the departments and agencies (Ayee, 1997: p. 42). The goal was to wean these bodies off the control of central government ministries, departments, and agencies in the national capital (Ayee, 1997: pp. 42-43). In doing so however, the problem of bureaucracy was not addressed, but merely hived off from national level institutions to local level bodies.

The imperative for a coordinated approach to the development process appears to be a primary factor underlying local and regional development. As a result, each metropolitan, municipal, and district assembly comprises a District Planning and Coordinating Unit. These units provide the bureaucratic framework within which the assemblies carry out their planning, supervisory, and evaluation goals. Moreover, they create a platform for the synchronization of the work of the various units and agencies under the ambit of the assemblies (Laryea-Adjei, 2000: p. 394). The emphasis on coordination carries through to the national level, bringing to the fore activities of the National Development Planning Commission. This body ensures that the operations of all 
the various metropolitan, municipal, and district assemblies are in sync towards attaining an overall national development agenda (Mohan, 1996b: pp. 442-445). Thus, it brings together all relevant stakeholders towards fashioning out a common development vision. However, the fact that it comprises a hierarchical administrative set-up adds to the bureaucratic nature of the governance process.

The bureaucracy associated with metropolitan governance in Accra and many other assemblies across Ghana is also demonstrated by the fact that much of the resources allocated to these local governmental units are expended on administrative items. These include salaries, accommodation, and transportation for staff of these assemblies (Ayee, 1997: p. 40). The allocation of resources towards recurrent expenses may be explained by the complex administrative set-up associated with each new local governmental unit as a result of the belief that such arrangements ensure better development coordination. Due to the relatively high administrative expenses however, relatively few resources are left to execute local development projects, a situation which creates challenges when it comes to public trust and confidence in the activities of these assemblies (Ayee, 1997: p. 40). It is therefore not difficult to perceive these local governmental units as a mere extension of the bureaucratic set-up of the national government, albeit in a slightly different form from what citizens may have been used to previously (Ayee, 1997: p. 41).

Overall, bureaucracy in Accra may be attributable to a long history of public sector-led development inherited from the days of British colonial rule. This history is associated with an institutional culture steeped in hierarchical layers, with little or no emphasis on local autonomy. The primary focus here is the creation of administrative structures which ensure that the agenda of the central government is achieved at the local 
level. Even in the democratic era where major political parties such as the NDC and NPP stress the need for decentralization, calls for the devolution of power are usually answered through the creation of new local governmental units; a situation which ultimately compounds the bureaucratic complexity associated with the delivery of governance outcomes. This arrangement stresses the need to generate society-wide development benefits in consonance with an overarching national interest. While the rationale is good in principle, much of its execution tends to be abortive in nature due to the fact that development initiatives tend to be stalled along hierarchical chains whose functions are not always clearly defined.

\subsection{Discussion}

Towards rationalizing the implications of globalization for rescaling in the two metropolitan areas within a critical realist framework, an examination of their political cultures, path-dependencies and histories is important. In Chicago, just like many other American metropolises, local autonomy is perceived as an inherent component of democratic expression. Thus, centralization of governance is widely received with much skepticism. As noted earlier, the revolutionary fervor associated with the birthing of the United States made citizens unenthusiastic about greater central government control. Moreover, annexation is strongly resisted in Chicago because of the fear by localities that doing so could cause them to surrender their interests to wider regional forces. This, coupled with the long history of mistrust between the central city and suburbs, has entrenched a highly fragmented form of government. In the recent past, the Illinois State 
Constitution of 1970 which granted the power of home rule to cities like Chicago has also promoted the culture of autonomous decision-making.

In the case of Accra, the resort to centralization emerged from the days of British colonial rule and was entrenched after independence when Ghana opted to become a unitary state. While it may be argued that centralization portends negatively for citizen engagement, it must be noted that various governments after the nation's independence, starting with Nkrumah, opted for this model as a way of protecting the overarching national interest. For instance, Nkrumah did so in order to unite the national front and avoid promoting sectional interests. Moreover, the government of Busia resorted to centralization in order to implement its development agenda at the local level through the shoring up of grassroots support. The Acheampong government also sought to centralize power for similar reasons. In the recent past, recentralization is arguably perceived as a prudent way of curbing corruption associated with the award of contracts and the disbursement of development funds at the local level. Since many citizens have relatively less interest in local politics (as opposed to what occurs at the national level), a strong case can be made that a centralized mode of local development financing for instance would attract greater public scrutiny and due diligence than what prevails at the local level. Perhaps, in furtherance of these goals, the Kufuor government, notwithstanding its avowed aim of promoting the devolution of power, introduced Local Government Act 656 which created a centralized mode of procurement for items such as sanitation equipment and stationery.

In the case of Chicago, the global era, with its focus on efficiency, brought to the fore the need for coordination of existing governmental units. This led to the emergence 
of powerful political machines mostly spearheaded by the two Mayor Daleys. The result was a strong mayor-weak council form of government, a situation quite different from what used to prevail up till the 1950s or so. However, while some consolidations have occurred in the recent past, the city-region's long political culture and history of autonomous decision-making have meant that a path-dependent resort to fragmentation still prevails. The implication is that while globalization may create the imperative for change in city-regional governance, context-specific realities may curtail, or at best slow down the pace of change. As noted in Chapter 2, Pierson (2000a, b) observed that due to the prospects for increasing returns to scale, a path-dependent process can only be broken by a powerful external force. In the case of Chicago, even though globalization, with its focus on governance efficiency, created the need for some level of coordination, localities bent on maintaining the status quo managed to ensure the prevalence of political fragmentation. Specifically, structural mechanisms steeped in history led to the entrenchment of decentralization, lending credence to the assertion by Sydow et al. (2010) on the structural import associated with path-dependency. Moreover, the development reinforced the argument by Martin and Sunley (2006) regarding the placespecific attributes associated with path-dependency.

Unlike Chicago, the wave of political reforms associated with the global era resulted in the need for some form of decentralization in Accra as a way of devolving power to local authorities and giving ordinary citizens a voice in the decision-making process. The result was the local government reform of 1988. Since then, the city-region has witnessed a proliferation of local governmental units aimed at entrenching local democracy and accountability. However, while globalization has led to some 
administrative and political devolution, Ghana's long political culture and history of concentration of power means that a path-dependency of centralization prevails. Centralization occurred in Accra because institutionally, various bureaucrats aligned with central government were keen on protecting their interests. Thus, even though an external force (i.e. globalization) as noted in the works of Pierson (2000a and 2000b), provided the incentive for reforms, entrenched local interests meant that the path which had been created since the days of British colonial rule could largely not be deviated from. Moreover, the development appeared to reinforce the argument by Martin and Sunley (2006) that institutional customs and usages inherited over time may be difficult to change due to entrenched interests. Also, as articulated in the work in Sydow et al. (2010), the import of human agency on the part of bureaucrats in the public sector ensured that the path of centralization was not broken.

\subsection{Summary}

To sum up, this chapter has examined the differential implications of globalization for the rescaling in Chicago and Accra in light of their unique local factors. It observes that the nature of rescaling in Chicago originates from the American Revolution which made many localities wary of being incorporated within the city boundaries. Thus, governance is decentralized and autonomous, a situation reinforced by the nature of mayoral politics. The result is a high degree of political fragmentation. Unlike Chicago, Accra's governmental system emanated from the days of British colonial rule when there was little or no emphasis on local autonomy, resulting in the 
outward expansion of the city-region. Thus, the nature of governance is centralized and underpinned by the desire to protect the national interest. These developments have been entrenched by strong central government control and bureaucracy. The next chapter is the concluding section of this study. 


\section{CHAPTER 7}

\section{CONCLUSIONS}

\section{Overview/Summary}

In order to conclude the study, this chapter will restate major findings, discuss research benefits, and make policy recommendations, as well as suggestions for future research. I set out in this inquiry to examine the differential implications of globalization for inter-local cooperation in the city-regions of Chicago, Illinois and Accra, Ghana (in the Global North and South, respectively). The study was important given the relative dearth of research on the global-local nexus with respect to regionalism. As noted earlier, this is a major shortcoming because of the pressing need for localities to pool efforts towards addressing inter-jurisdictional challenges in the global era. The study sought to answer three major questions. First, how does globalization in Chicago and Accra compare and contrast given the unique local contexts of the two city-regions? Here, my goal was to find out whether the nature of global engagement by the two metropolitan areas can be explained by their economic, political, and historical contexts. Second, this study inquired: how do local factors in Chicago and Accra mediate the implications of globalization for their respective approaches to regional cooperation? Here, I argued that the economics, politics, path-dependencies, and histories of the two city-regions are crucial towards influencing their approaches to regional cooperation in the global era. Moreover, given my earlier observations that that inter-local cooperation is a form of 
rescaling, I addressed a third research question: what are the differential implications of globalization for rescaling in Chicago and Accra, given their respective local contexts?

Here, I sought to answer the question in light of the political cultures, path dependencies, and histories of the two city-regions.

Towards achieving my research goals, I employed a host of methodological approaches such as the case study technique, critical realism, comparative analysis, and qualitative approach. The case study method was adopted so that I could examine indepth the subjects of interest within their real-world contexts. Specifically, I chose Chicago and Accra because given their respective locations in the Global North and South and the fact that they have been affected very differently by globalization, a compelling case can be made for a comparative analysis. Besides, the two city-regions have distinct approaches to regional cooperation. Specifically, Chicago is associated with networked governance, while Accra has a regional government. Moreover, rescaling is manifested differently in the two metropolitan areas as Chicago is politically fragmented, while Accra is centralized. Also, given the sister-city relationship between the two metropolitan areas vis-à-vis my familiarity with them, their choice was appropriate.

The case study approach adopted in this research ties in very well with the analytical framework of critical realism. As noted in Chapter 3, critical realism argues that phenomena in the real world may be explained in light of the wider frameworks (such as the economic, political, and historical contexts) within which they are embedded. I also adopted a comparative analysis so that I could compare and contrast how the phenomena of interest in this study are manifested in different settings. Similarly, the qualitative approach was useful because this study examines phenomena 
(in-depth) within particular contexts. The research was exploratory in nature and relied on secondary data, discourse analysis, and interviews to achieve its objectives. The exploratory approach was necessitated by the need to explain in detail, what accounts for the phenomena of interest. Secondary data and discourse analyses were also useful, given the work which had already been done on the two city-regions.

Notwithstanding the reliance on secondary data and discourse analysis, interviews were still important as a way of gauging what exists on the ground i.e. in light of the existing literature. Specifically, I conducted a total of 10 interviews (i.e. 5 in each cityregion). For each metropolitan area, two prominent members of the business/investment community were asked questions relating to foreign direct investment, the presence of global firms, and the role of the private sector. Moreover, three local/planning officials in each city-region were interviewed about the nature of inter-local cooperation and governance/government, as well as how these have evolved over the years (especially in the global era). The research questions, together with the main findings from the study, are summarized in the following table. 
Table 7.1 Research Summary

\begin{tabular}{|c|c|c|}
\hline \multirow[t]{2}{*}{ Research Questions } & \multicolumn{2}{|c|}{ Findings } \\
\hline & Chicago & Accra \\
\hline \multirow[t]{3}{*}{$\begin{array}{l}\text { 1. What is the nature } \\
\text { of globalization in } \\
\text { Chicago and Accra } \\
\text { given their unique } \\
\text { local contexts? }\end{array}$} & $\begin{array}{l}\text { i. Chicago serves as a } \\
\text { headquarter location for } \\
\text { global service firms because } \\
\text { of its strategic location in the } \\
\text { Global North, importance in } \\
\text { the global economy, and } \\
\text { long history of private sector } \\
\text { engagement. }\end{array}$ & $\begin{array}{l}\text { ii. Accra serves as a location } \\
\text { for subsidiaries or local } \\
\text { branches of global firms due } \\
\text { to its relatively less prominent } \\
\text { role in the global economy } \\
\text { and nascent stage of private } \\
\text { sector engagement. }\end{array}$ \\
\hline & $\begin{array}{l}\text { ii. Chicago's level of foreign } \\
\text { direct investment is } \\
\text { comparable to other major } \\
\text { American urban areas } \\
\text { because investment flows are } \\
\text { spread out across the United } \\
\text { States. }\end{array}$ & $\begin{array}{l}\text { ii. Accra accounts for the bulk } \\
\text { of Ghana's foreign direct } \\
\text { investment due to its status as } \\
\text { the nation's primate city. }\end{array}$ \\
\hline & $\begin{array}{l}\text { iii. The global era in Chicago } \\
\text { is associated with public- } \\
\text { private collaborative } \\
\text { platforms and civic } \\
\text { engagement in consonance } \\
\text { with the American ethos of } \\
\text { privatism and democracy. }\end{array}$ & $\begin{array}{l}\text { iii. Political globalization in } \\
\text { Accra is characterized by } \\
\text { institutional restructuring } \\
\text { because of a strong public } \\
\text { sector role in the development } \\
\text { of the city-region. }\end{array}$ \\
\hline \multirow[t]{2}{*}{$\begin{array}{l}\text { 2. How do local } \\
\text { factors in Chicago } \\
\text { and Accra mediate } \\
\text { the implications of } \\
\text { globalization for } \\
\text { regional cooperation } \\
\text { in the two } \\
\text { metropolitan areas? }\end{array}$} & $\begin{array}{l}\text { i. Regionalism in Chicago is } \\
\text { associated with complex } \\
\text { networks (based on } \\
\text { governance) because: this } \\
\text { arrangement ensures local } \\
\text { autonomy and still enables } \\
\text { solutions to be found to } \\
\text { regional problems. }\end{array}$ & $\begin{array}{l}\text { i. Regionalism in Accra is } \\
\text { based on hierarchical } \\
\text { structures (i.e. government) } \\
\text { due to: a historical vestige of } \\
\text { public sector-led } \\
\text { development; and the desire } \\
\text { to ensure better development } \\
\text { coordination. }\end{array}$ \\
\hline & $\begin{array}{l}\text { ii. The nature of regional } \\
\text { cooperation in Chicago is } \\
\text { fluid, voluntary, and } \\
\text { informal due to: mistrust } \\
\text { between the central city and } \\
\text { suburbs; a strong civic } \\
\text { culture; and the imperative to } \\
\text { protect local autonomy. }\end{array}$ & $\begin{array}{l}\text { ii. Regional cooperation in } \\
\text { Accra is administrative, } \\
\text { directed, and formal in nature } \\
\text { because of: strong central } \\
\text { government control; and the } \\
\text { desire to promote regional } \\
\text { efficiency. }\end{array}$ \\
\hline
\end{tabular}




\begin{tabular}{|c|c|c|}
\hline & $\begin{array}{l}\text { iii. There is a strong private } \\
\text { sector role with respect to } \\
\text { regional cooperation in } \\
\text { Chicago because the city- } \\
\text { region operates as an } \\
\text { efficiency-maximizing } \\
\text { organization which seeks to } \\
\text { compete in the global } \\
\text { economy. }\end{array}$ & $\begin{array}{l}\text { iii. There is a strong public } \\
\text { sector role as regards } \\
\text { regionalism in Accra because } \\
\text { political actors place } \\
\text { emphasis on the pursuit of } \\
\text { policies which yield collective } \\
\text { benefits for the wider society. }\end{array}$ \\
\hline \multirow{3}{*}{$\begin{array}{l}\text { 3. What are the } \\
\text { differential } \\
\text { implications of } \\
\text { globalization for } \\
\text { rescaling in Chicago } \\
\text { and Accra given their } \\
\text { unique local } \\
\text { contexts? }\end{array}$} & $\begin{array}{l}\text { i. As a result of American } \\
\text { revolutionary origins which } \\
\text { made citizens wary of } \\
\text { centralization, localities are } \\
\text { resistant to annexation by } \\
\text { Chicago. }\end{array}$ & $\begin{array}{l}\text { i. Due to British colonial and } \\
\text { postcolonial origins which } \\
\text { placed little or no emphasis } \\
\text { on local autonomy, Accra } \\
\text { continues to expand outwards } \\
\text { territorially. }\end{array}$ \\
\hline & $\begin{array}{l}\text { ii. In consonance with the } \\
\text { American democratic ethos, } \\
\text { Chicago is associated with } \\
\text { local autonomy and strong } \\
\text { mayoral politics. }\end{array}$ & $\begin{array}{l}\text { ii. Towards ensuring a } \\
\text { coordinated approach to the } \\
\text { development process, Accra is } \\
\text { characterized by strong } \\
\text { central government control } \\
\text { and emphasis on the national } \\
\text { interest. }\end{array}$ \\
\hline & $\begin{array}{l}\text { iii. Due to the prevalence of } \\
\text { local autonomy, the global } \\
\text { era in Chicago is associated } \\
\text { with political fragmentation. }\end{array}$ & $\begin{array}{l}\text { iii. Given its historical vestige } \\
\text { of public sector-led } \\
\text { development, Accra is marked } \\
\text { by bureaucracy in the global } \\
\text { era. }\end{array}$ \\
\hline
\end{tabular}

(Source: Author's construct based on literature, discourse analysis, and interviews)

\subsection{Research Benefits and Contributions}

This study has been useful for several reasons. First, it has lent more empirical evidence to the assertion that globalization, while extra-local in its origins, has local ramifications. For instance, while both Chicago and Accra experienced globalization, differences in local factors meant that results (such as presence of global firms, levels of 
foreign direct investment, public-private partnerships, civic engagement, and institutional restructuring) were appreciably different from each other. The findings indicate that much of the existing literature on globalization focuses on how the phenomenon is manifested in North America and Western Europe, implicitly assuming that what prevails in these parts of the world automatically apply elsewhere. However, as shown in this study, the inherent differences in the economics, politics, and histories of the Global North and South, respectively, mediate the implications of globalization for these respective parts of the world.

Chicago and Accra have different levels of strategic importance or "positionalities" in the global economy. According to Sheppard (2002: p. 319), "positionality calls attention to how connections between places play a key role in the emergence of geographic inequalities within the global economy; inequalities that show remarkable persistence and path dependence, notwithstanding the new possibilities that globalization supposedly creates for all." As a result of these inequalities, greater interconnections exist between major city-regions in the Global North than emerging urban areas in the Global South. In the case of Chicago, the city-region's long engagement with the global economy occurs primarily because of its strategic location which makes it a nodal point for transportation and commerce. This has enhanced the economic stature of the metropolitan area through networks with other places and actors around the globe. As a result, the city-region belongs in the core of global economic activity. Unlike Chicago however, Accra's engagement with the global economy is largely envisaged in terms of powerful multinationals from elsewhere locating their branches there. This relationship mirrors the economic interdependencies which largely 
characterized the relationship between the West and Africa in the days of colonial rule. It may therefore be argued that relatively speaking, the positionality of Accra places it at the margins of global economic activity.

Sassen's global city model is underpinned by the principle of reductionist Marxism and therefore assumes that the power and influence of multinational corporations now defy territorial boundaries. Moreover, the analyses by Brenner (1999a and 1999b) and Swyngedouw (2004) argue that globalization results in: an upward scaling of power away from the nation-state towards supra-national forces; and a downward scaling towards regions and localities. Admittedly, in major city-regions within the Global North (such as Chicago) which have a long history of global economic engagement, the important role played by multinationals is undeniable. This role has been reinforced by the American ethos of free markets, which focuses on the private sector as the driver of economic growth. Besides, the focus on local autonomy in the American context has resulted in the devolution of power towards these sub-national players. It is however important to note that even though much of the rest of the world is increasingly embracing economic and political reforms, the national context still remains an important determinant of how private capital moves across many places in the Global South. This is due to the emphasis on centralization; a situation derived in part from the need to protect localities from the vagaries associated with the movement of private capital. In the case of Accra for instance, the Government of Ghana remains a prominent player when it comes to the operation of multinational corporations. This situation has been reinforced by a long history of public sector-led development, interspersed only in the recent past by the rolling out of liberal economic reforms. Besides, even though local government 
reforms have occurred in the recent past, much of it is administrative in nature, with the national government still playing a vital role in the development of the city-region.

As noted in Chapter 4, Chicago is an alpha city because it connects an important region with the rest of the global economy. In terms of regionalism in particular, Chicago's level of global engagement is evident because localities increasingly have a sense of connection, both with each other and other places around the world. There therefore arises the need for these locales to cooperate as a way of ensuring the economic competitiveness of the city-region (as a whole) in the global economy. In the case of Accra, the city-region's status of gamma minus implies that relatively speaking, it connects a smaller region with the rest of the global economy. The imperative for connectedness (and thus cooperation) among localities is therefore not as pressing as it is the case for Chicago.

This study has clearly expanded the scope of existing research by demonstrating how the global-local nexus applies when it comes to the organization of collective action on a metropolitan aggregate scale. Given the relatively little research which exists on how the interactions between global and local forces account for regional cooperation, the importance of this inquiry can therefore not be underestimated. For instance, works such as Vogel (2000), Kacowicz (1998), and Savitch and Kantor (2002) observed that globalization brings about the need for cooperation among adjoining jurisdictions without considering in-depth, how unique local factors mediate the approach towards cooperation. As shown in this study, localities in metropolitan areas such as Chicago have a compelling need to cooperate because high levels of political fragmentation associated with local autonomy imply that in the absence of cooperation, metropolitan 
development will proceed in a chaotic fashion. Moreover, autonomy entails that cooperation, when it occurs, is usually fluid, voluntary, and informal in nature. In the case of Accra however, while some level of cooperation occurs among adjoining governmental units, the highly centralized nature of the planning and development process means that collaboration is not necessarily an important issue. This makes cooperation more of an implicit component of a wider hierarchical regional governmental framework; rather than an explicitly defined goal. Besides, centralization implies that even when cooperation occurs, it is usually administrative, directed, and formal in nature.

Much of the existing literature on regionalism has focused on only the roles of local factors in accounting for this phenomenon. For instance, works such as Andersen and Pierre (2010), Jung and Kim (2009), Jacobs (2004), Visser (2002), and Feiock (2007) all examine the local context of regionalism. This study has demonstrated that global factors also play vital roles in accounting for regionalism. In the case of Chicago, the global context of regional cooperation was evident in the emergence of bodies such as the Metropolitan Mayors' Caucus and the Joint Committee on City-County Collaboration. These bodies seek to ensure better coordination in the development of the metropolitan area as a way of enhancing its competitive edge. And for Accra, globalization has resulted in institutional restructuring with the goal of promoting administrative efficiency at the regional level. This has led to the formation of new local governmental units and the emergence of a regional government i.e. the Greater Accra Regional Coordinating Council.

It is also important to note that this research has added to the existing discourse on the ramifications of globalization for rescaling at the metropolitan level. Studies such as 
Tsukamoto and Vogel (2007) attribute decentralization and centralization primarily to global forces. Also, works by Brenner (1999a and 1999b) and Swyngedouw (2004), which talk about how local factors interface with global elements, mostly focus on the Global North. This research has shown that local factors, in both the Global North and South, are crucial when it comes to examining how globalization affects the nature of rescaling in a metropolitan area. In the case of Chicago, while the Daley Machine resulted in strong mayoral control as a way of ensuring better coordination, the revolutionary origins associated with the birthing of the American polity meant that local autonomy prevailed. This was evident in the resistance to annexation and high levels of political fragmentation associated with the metropolitan landscape. And for Accra, globalization resulted in increased administrative devolution as a way of reducing overcentralization. However, the long history of public sector-led development associated with British colonial and postcolonial origins meant that central government control remained strong. These developments were demonstrated by the continuous expansion of the city, a situation fueled by the lack of local autonomy, coupled with bureaucracy.

Three observations are particularly evident to me from the findings of this study. First, globalization is best understood with respect to local context. This is because, what the phenomenon portends differs from one place to another based on the economic, political, and historical dynamics of specific jurisdictions. I could therefore not agree more with Robertson (1992) who observed that the interactions between global and local elements result in "global localization." That is, various localities respond differently to globalization, resulting in uniquely different local identities even in the midst of the increased role of supra-local elements. I therefore argue in this study that while 
globalization may entail the notions of the upward and downward scaling of power away from the nation-state, the extent to which this rescaling occurs depends very much on local context. This is because, in the Global North, the culture of privatism, coupled with increased global engagement, generally results in a de-emphasis of the nation-state as the primary force which regulates the operations of multinational corporations in cityregions. In the Global South, the strong role of the public sector and the need to protect the overarching public interest mean that national governments remain important regulators of the operations of global firms in metropolitan areas.

Second, this study observes that while globalization is associated with the imperative for regional cooperation, this collaboration is more of a pressing need in politically fragmented regions, rather than centralized polities. In metropolitan areas where political fragmentation exists, cooperation comes across as the best way of achieving regional development coordination. This is because it enables the pooling of synergies by autonomous jurisdictions towards achieving common goals. Moreover, inter-local cooperation helps these fragmented areas to emerge as a common bloc towards facilitating regional competitiveness in the global era. I observe that while localities, particularly in the Global North, still operate as efficiency-maximizing organizations in order to enhance their competitive edge (i.e. as per Peterson's 1981 analysis), the scale of the competition has now shifted from the local to the regional level. In the global era, localities (especially those in politically-fragmented regions), cooperate so that they can compete en bloc at the regional level. Cooperation is also more feasible in politicallyfragmented regions because it represents the most viable way of fashioning out regional solutions, while still maintaining local autonomy. Due to the unwillingness of such 
autonomous jurisdictions to cede their sovereignty to wider regional forces, cooperation by virtue of its fluidity and voluntariness helps to ensure a healthy balancing act between two desirable goals: maintaining local autonomy and addressing regional problems.

Unlike politically-fragmented metropolitan areas, centralized polities have a wide array of options available to them for attaining regional efficiency. As a result, interjurisdictional cooperation is usually not an explicitly defined goal, even in the global era. To begin with, a top-down administrative mechanism ensures that localities are whipped in line towards the attainment of regional development goals. Thus, even when cooperation occurs, it is merely determined by the need to ensure the efficient operation of existing institutional frameworks. Moreover, the desire to attain regional economic competitiveness is not necessarily a compelling motivation for cooperation. This is due to the fact that political actors seek to pool synergies from various localities largely in furtherance of desirable societal goals such as poverty reduction. It is also important to note that the need to collaborate with one's neighbors is more compelling in situations where local autonomy makes regional governance a virtual impossibility. However, in cases where a regional government exists, metropolitan governance becomes more feasible, meaning that cooperation is more of an implicit (rather than an explicitlydefined) goal.

Third, this study observes that rescaling is a local dimension of a global phenomenon, which is manifested with respect to both the spatial and political realms. This is evidenced by the fact that the nature of the reterritorialization process associated with globalization is very much context-dependent. As a result, while the phenomenon sometimes results in resistance to annexation, it leads (at other times) to territorial 
expansion. In one context, resistance to annexation occurs as a result of the need to preserve local autonomy. In another situation however, territorial expansion epitomizes the lack of autonomy associated with strong central government control. Evidently, rescaling in one context may entail decentralization because of the power available to localities to make their own decisions. In another case however, the imperative to protect the overarching national interest implies that rescaling results in centralization.

\subsection{Policy Recommendations}

Towards making policy recommendations given my research findings, one issue that comes to mind is whether Chicago's model of regionalism will be good for Accra or vice versa. This study argues that because the American and Ghanaian contexts are very different, it would be imprudent to assume that what works in the Global North automatically applies in the Global South and vice versa. In the United States, inter-local cooperation is a topical issue because political fragmentation heightens the need for cooperation in order to address regional challenges. The situation for Ghana is however different as centralized planning implies that cooperation amongst adjoining jurisdictions is not necessarily the biggest issue on the development agenda. Besides, in the American context, local autonomy is regarded as a defining feature of democratic expression; and in Ghana, centralization is crucial to protecting the overarching national interest.

The arguments by various scholars regarding the merits of having a multiplicity of local governmental units in a metropolitan area are well noted. For instance, Ostrom (2000) asserted the "self-evident truth" regarding the inefficiencies associated with polycentric governance turn out to be unfounded when evaluated in light of empirical 
facts. Specifically, an examination of police agencies in 80 city-regions across the United States found metropolitan areas with the largest number of such agencies witnessed better police protection or public safety than those with fewer police agencies. Also, contrary to popular perceptions that consolidations result in lower costs of service delivery, studies by scholars such as Benton and Gamble (1984) noted that the reverse is actually the case. Savitch et al. (2009) also found the much talked about economic development which was supposed to come about in light of the Louisville city-county consolidation of 2003 did not materialize. Based on the plethora of evidence from the works of various scholars regarding the merits associated with political fragmentation, this study recommends that Chicago should continue its rich tradition of local autonomy. This is because autonomy comes across as a more intentional way of providing basic services to communities. Besides, autonomy by its nature entails a greater focus on citizen representativeness, making it more responsive to local issues.

The aforementioned observations notwithstanding, this study also observes that the need to deal with inter-jurisdictional problems cannot be discounted in the global era. Towards addressing inter-jurisdictional challenges while still maintaining local autonomy, it is recommended that Chicago should continue with its prevailing practice of networked governance. Thus, recent initiatives such as the emergence of the Metropolitan Mayors' Caucus and the Chicago Metropolitan Agency for Planning must be commended. However, it is proposed that these bodies should be accorded some form of enforcement powers so that they can achieve their desired regional goals. This will be crucial towards stemming the tide of poor coordination associated with development in the city-region. Undeniably, this recommendation may ruffle feathers in a city-region 
which cherishes local autonomy so much. Thus, for a start, it is suggested that such powers should be limited to regional initiatives around which some form of consensus exists. Moreover, towards eliciting their participation in regional ventures, localities must be educated on the benefits not just for the wider region, but also for their individual jurisdictions.

During interviews conducted as part of this study, one respondent bemoaned the number of governmental units in the Chicago Metropolitan area and noted:

\footnotetext{
"The sheer number of units of government we have is confusing at best. It is intimidating. It is daunting. It is stifling. All these governmental units control money, the ability to hand out jobs; and there continue to be patronage issues. Inertia is our biggest problem. No one has successfully told a compelling story about what the lack of a metro government costs us."
}

Given the lack of a regional government for the Chicago Metropolitan Area, this study proposes a forensic evaluation should be carried out to ascertain what this status quo portends for regional efficiency. Admittedly, much evidence exists on the benefits associated with political fragmentation. However, a study which focuses on Chicago in particular would be useful as a way of assessing whether regionalism, as it currently prevails in the metropolitan area, is necessarily as efficient as it could possibly be. This will help to address the concerns of both proponents and opponents of political fragmentation. Moreover, such an evaluation will help to determine whether some level of consolidation of existing governmental units may indeed be necessary to engender regional efficiency.

In the case of Accra, this research acknowledges (based on the existing literature) that centralization has some benefits as well. For instance, scholars such as Derksen 
(1988) and Dolan (1990) observe that consolidation provides a financial lifeline to smaller jurisdictions which have very few fund-raising mechanisms. This is because such smaller areas can benefit from the wider resource pool available at the regional level. Besides, centralization comes across as a practical way of ensuring a coordinated approach to regional development. This is because it creates a "more comprehensive and integrated regional land use planning" mechanism (Ayee, 2012: p. 4). The study therefore commends the existence of a regional body, such as the Greater Accra Regional Coordinating Council.

This research also observes that the need may exist for some level of centralization in the Ghanaian context as a way of protecting the national interest and ensuring public accountability. However, this must be carried out in a way which does not portend negatively for economic competitiveness and local autonomy in this renowned African democracy. Towards attaining this, it is strongly recommended that the nomination of metropolitan, municipal, and district chief executives by the central government should be scrapped. In its place should be the direct election of these officials through universal adult suffrage on a partisan basis. In London for instance, the direct election of mayors since 2000 has led to more focus on the entrepreneurial bent. This occurs because of increased interactions between the mayor and the business community with the goal of enhancing the competitive edge of the city-region (Thornley et al., 2005). And in Germany, the direct election of mayors which swept across many parts of the country in the 1990s sought in part to devolve power to citizens and enhance political representativeness (Wollmann, 2004). 
Since Ghana's return to democratic rule in the early 1990s, local elections have attracted record low levels of participation (compared to presidential and parliamentary polls). This may be attributed, at least in part, to strong central government control and the non-partisan nature of such polls which make it difficult for voters to assess the ideological orientations of candidates. Admittedly, some level of central government control may be crucial in the Ghanaian context towards ensuring public accountability at the local level. A strong case can also be made that a non-partisan mode of local elections reduces political rancor at this level. I however argue in this study that the existing arrangement regarding the direct nomination of mayors by the central government does not allow for much economic and political innovation on the part of these mayors (as they are more concerned about pleasing their appointing authorities). Moreover, the nonpartisan nature of local elections reduces citizen interest and participation in local level politics (as opposed to what prevails at the national level). Besides the direct election of mayors, this study also recommends that more platforms for citizen engagement at the local level should be created. These should take the form of regular public forums characterized by brainstorming on development goals for localities. Moreover, a proactive system of local government accountability which incorporates at least some level of public input should be put in place to curb acts of corruption evident in the award of some contracts at the local level.

In order to cut down on bureaucratic bottlenecks associated with regional development, it is also recommended that a functional, rather than an administrative approach, should guide the creation of new local governmental units henceforth. In other words, rather than the blanket establishment of new administrative structures, a 
functional designation which attracts increased resource allocations for addressing specific challenges should be the key. For instance, localities such as Adentan and Teshie-Nungua should be designated as water districts. This designation should not come with any office or bureaucratic set-up. Rather, it should result in increased resource allocations from both the coffers of the central government and relevant development partners towards permanently addressing the problems of water supply which have long bedeviled these areas. Besides Adentan and Teshie-Nungua, places such as Old Fadama (commonly referred to as Sodom and Gomorrah) should be designated as sanitation districts as a way of attracting resources towards dealing with waste management and related challenges. Moreover, areas such as Chorkor and Mamobi should be declared economic development districts. This designation must attract investments in the form of job creation and skills training towards reducing the appreciably high levels of poverty in these places.

According to Ayee (2012), the constitutional requirement of economic feasibility is often ignored when it comes to the creation of new local governmental units in Ghana. This is due in part to the desire to satisfy the demands by political party activists at the local level for their own governmental units. The result however has been the overreliance of the newly created local governments on funds from the central government, thereby limiting their independence. This study therefore recommends a strict enforcement of this constitutional requirement on economic feasibility whenever any new metropolitan, municipal, or district assemblies are being created. This will make it possible for them to raise much of the revenues required to finance their activities from internal sources, thereby making them less dependent on the central government. 
Overall, the research observes that regionalism in the global era is contextdependent. Thus, it is recommended that the promotion of inter-jurisdictional cooperation as an explicit goal should be more of a priority in politically-fragmented regions. This will help to curb the problems associated with the pursuit of conflicting development agendas by autonomous localities. In metropolitan areas characterized by centralized planning (especially those based on the institutional imperative), the cutting down on administrative and bureaucratic bottlenecks should be a more pressing concern towards enhancing regional efficiency in the global era.

\subsection{Future Research}

This study will conclude by discussing a number of possible avenues for future research. Some of these were suggested by members of my dissertation committee, but could either not be covered in detail or examined at all in the inquiry due to resource constraints such as data and time availability. Going forward therefore, I intend to explore at least some of these research issues in detail. Specifically, is there a positive relationship between decentralization or centralization and the attraction of foreign direct investment to Chicago and Accra; and why might this be the case? How much incentives (such as concessions, tax laws, and subsidies) are there for promoting foreign direct investment in the two metropolitan areas? How much is the leadership in the two cityregions willing to give in order to promote foreign direct investment? What are the fundamental differences between Chicago and Accra; and why is there likely to be more or less investment in one city-region than the other? What is the role of China when it comes to foreign direct investment in Africa (within the global era)? 
Many other research avenues abound. For instance, future inquiries should look at which of the respective approaches to regional cooperation in the two metropolitan areas (i.e. complex networks and multitiered) is more efficient in the delivery of governance/government outcomes. Similarly, investigations should examine the relative effectiveness of the decentralized and centralized approaches to rescaling in the two cityregions. Moreover, there should be research regarding the implications of the respective approaches by Chicago and Accra to regionalism i.e. with respect to active citizen engagement, democratic expression, and public interest in the global era. Also, given that Chicago and Accra are sister cities, future studies should examine the degree to which these cross-border collaborative platforms promote cultural exchanges between the two city-regions in the global era. Finally, research should investigate the extent to which the strategic and relatively centralized locations of the two city-regions account for their respective footholds in the global economy. 


\section{REFERENCES}

Abrahamson, M. (2004). Global cities. New York \& Oxford: Oxford University Press.

Abu-Lughod, J. L. (1995). Comparing Chicago, New York, and Los Angeles; testing some world city hypotheses. In P. L. Knox, \& P. J. Taylor (Eds.), World cities in a world system (pp. 171-191). Cambridge, UK: Cambridge University Press.

Accra Metropolitan Assembly. (2006). Historical background: the Accra Metropolitan Assembly. Retrieved from http://ama.ghanadistricts.gov.gh/?arrow $=$ atd\&_=3\&sa=2995

Accra Metropolitan Assembly. (2013). 2012 annual progress report: Ghana Shared Growth and Development Agenda (GSGDA).

Accra Metropolitan Assembly. (n.d.). Sub metro. Retrieved from http://www.ama.gov.gh/ama/page/5052/sub-metro

Accra Planning and Development Programme in association with the United Nations Development Programme and the United Nations Center for Human Settlements. (n.d.). Strategic plan for the Greater Accra Metropolitan Area. Volume 1 context report: draft final report.

Acworth, W. (2013). FIA annual volume survey: commodity and interest rate trading push trading higher in 2013. Retrieved from http://www.futuresindustry.org/downloads/FIA_Annual_Volume_Survey_2013.p df

Adams, F. G. (2011). Globalization, today and tomorrow. London and New York: Routledge: Taylor and Francis Group.

Agyeman-Duah, B. (1987). Ghana, 1982-6: the politics of the PNDC. The Journal of Modern African Studies, 25(4), 613-642.

Albrechts, L., Healey, P., and Kunzmann, K. R. (2003). Strategic spatial planning and regional governance in Europe. Journal of the American Planning Association, 69(2), 113-129. doi:10.1080/01944360308976301

Allen, J. and Thompson, G. (1997). Think global, then think again - economic globalization in context. Area, 29(3), 213-227.

Alperovitz, G. (2011). America beyond capitalism: reclaiming our wealth, our liberty, and our democracy. Democracy Collaborative Press. 
Althuser, A., Morrill, W., Wolman, H., \& Mitchell, F. (Eds.). (1999). Governance and opportunity in metropolitan America. Washington, DC: National Academy Press.

Andersen, O.J. and Pierre, J. (2010). Exploring the strategic region: rationality, context, and institutional collective action. Urban Affairs Review, 46(218). doi: $10.1177 / 1078087410367756$

Antwi, K. B. and Analoui, F. (2008). Reforming public sector: facing the challenges of effective human resource development policy in Ghana. Journal of Management Development, 600-612. Retrieved from http://dx.doi.org/10.1108/02621710810877848

Arthur, W. B., Ermoliev, Y. M., and Kaniovski, Y. M. (1987). Path dependent processes and the emergence of macrostructure. European Journal of Operational Research, 30, 294-303.

Arthur, W. B. (1989, March). Competing technologies, increasing returns, and lock-in by historical events. The Economic Journal, 99(394), 116-131. Retrieved from http://www.jstor.org/stable/2234208

Arthur, W. B. (1990, February). Positive feedbacks in the economy. Scientific American, 92-99.

A. T. Kearney. (2014). 2014 Global cities index and emerging cities outlook: global cities, present and future.

Atkins, P. S. and Wilson-Gentry, L. . (1992, Fall/Winter). An etiquette for the 1990s regional council. National Civic Review, 262, 466-487.

Atkinson, R. D. (1998). Technological change and cities. Cityscape: A Journal of Policy Development and Research, 3(3).

Awortwi, N. (2011). An unbreakable path? A comparative study of decentralization and local government development trajectories in Ghana and Uganda. International Review of Administrative Sciences, 77(2), 347-377.

Ayee, J. R. A. (1996). Ghana: a top-down initiative. In D. Olowu \& J. Wunsch, Local governance in Africa: the challenges of democratic decentralization (pp. 125154). Boulder, Colorado and London, United Kingdom: Lynne Rienner Publishers, Inc.

Ayee, J. R. A. (1996, January). The measurement of decentralization: the Ghanaian experience, 1988-92. African Affairs, 95(378), 31-50. Retrieved from http://www.jstor.org/stable/723724

Ayee, J. R. A. (1997, September). The adjustment of central bodies to decentralization: the case of the Ghanaian bureaucracy. African Studies Review, 40(2), 37-57.

Ayee, J. R. A. (2012). The political economy of the creation of districts in Ghana. Journal of Asian and African Studies, O(0). doi:10.1177/0021909612464334 
Bailey, R. (1989). Strategic planning and large-city governance. Proceedings of the Academy of Political Science, 37(3), 167-179. Retrieved from http://www.jstor.org/stable/1173760

Bamberger, M., Rugh, J., and Mabry, L. (2011). Real world evaluation: working under budget, time, data, and political constraints - a condensed summary overview. Los Angeles, London, New Delhi, Singapore, and Washington D.C.: Sage.

Beall, J. (2002). Globalization and social exclusion in cities: framing the debate with lessons from Africa and Asia. Environment and Urbanization, 14(41). doi:10.1177/095624780201400104

Beck, U. (2000). What is globalization? Polity Press.

Becker, C.M., Hamer, A.M., and Morrison, A.R. (1994). Beyond urban bias in Africa: urbanization in an era of structural adjustment. Portsmouth, NH \& London: Heinemann \& James Currey Ltd.

Bennett, L. (2006). Chicago's new politics of growth. In J. P. Koval, L. Bennett, M. I. Bennett, F. Demissie, R. Garner, \& K. Kim (Eds.), The new Chicago: a social and cultural analysis (pp. 44-55). Philadelphia, PA: Temple University Press.

Bennett, L. (2006). Regionalism in a historically divided metropolis. In J. P. Koval, L. Bennett, M. I. Bennett, F. Demissie, R. Garner, \& K. Kim (Eds.), The new Chicago: a social and cultural analysis (pp. 277-285). Philadelphia, PA: Temple University Press.

Benton, J. E. and Gamble, D. (1984). City/county consolidation and economies of scale: evidence from a time-series analysis in Jacksonville, Florida. Social Science Quarterly,65, 190-198.

Berg, B. (1995). Qualitative research methods for the social sciences (Second ed.). Boston, London, Toroto, Sydney, Tokyo, and Singapore: Allyn \& Bacon.

Black, C. E. (1966). The dynamics of modernization: a study in comparative history. New York, Evanston, and London: Harper \& Row, Publishers.

Bobo, L.D. and Massagli, M.P. (2001). Stereotyping and urban inequality. In A. O'Connor, C. Tilly, \& L. Bobo, Urban inequality: evidence from four cities (pp. 89-162). New York: Russell Sage Foundation.

Boudreaux, D. J. (2008). Globalization. Westport, Connecticut and London: Greenwood Press.

Bray, D.W. and Bray, M.W. (2002, November). Beyond neoliberal globalization: another world. Latin American Perspectives, 29(6), 117-126. Retrieved from http://www.jstor.org/stable/3185005 .

Brenner, N. (1997). Global, fragmented, hierarchical: Henri Lefebvre's geographies of globalization. Public Culture, 10(1), 135-167. 
Brenner, N. (1998, Spring). Global cities, glocal states: global city formation and state territorial restructuring in contemporary Europe. Review of International Political Economy, 5(1), 1-37.

Brenner, N. (1999a). Beyond state-centrism? Space, territoriality, and geographical scale in globalization studies. Theory and Society, 28, 39-78.

Brenner, N. (1999b). Globalisation as reterritorialisation: the re-scaling of urban governance in the European Union. Urban Studies, 36(3), 431-451.

Brenner, N. (2003). Metropolitan institutional reform and the rescaling of state space in contemporary Western Europe. European Urban and Regional Studies, 10(4), 297-324. doi:10.1177/09697764030104002

Bridge, G. and Watson, S. (2010). The blackwell city reader (Second ed.). West Sussex, United Kingdom: Blackwell Publishing Ltd.

Briggs, J. and Yeboah, I. A. E. (2001). Structural adjustment and the contemporary subSaharan African city. Area, 33(1), 18-26.

Bryman, A. (1984, March). The debate about quantitative and qualitative research: a question of method or epistomology? The British Journal of Sociology, 35(1), 7592.

Burgel, G. and Burgel, G. (1996). Global trends and city policies: friends or foes of urban development. In M. Cohen, J. B. Ruble, J. S. Tulchin, \& A. Garland (Eds.), Preparing for the urban future: global pressures and local forces (pp. 301-335). Washington, D. C.: The Woodrow Wilson Center press.

Burns, N. (1994). The formation of American local governments. New York and Oxford: Oxford University Press, Inc.

Cain, L. P. (2005). Annexation. Retrieved from The Electronic Encyclopedia of Chicago: http://www.encyclopedia.chicagohistory.org/pages/53.html

Center for Remote Sensing and Geographic Information Services (CERSGIS) and ESRI. (2012 and 2015). Ghana districts. Retrieved from http://geocommons.com/overlays/201941

Center for Remote Sensing and Geographic Information Services (CERSGIS). (2015). Miscellaneous shapefiles and data. Obtained directly from the center.

Chen, Y.-C. and Thurmaier, K. (2009, September). Inter-local agreements as collaborations: an empirical investigation of impetuses, norms, and success. The American Review of Public Administration, 39(5), 536-552. doi: $10.1177 / 0275074008324566$

Chicago Council on Global Affairs. (2011). Capturing Chicago's global opportunity: a memorandum from a global Chicago advisory committee. 
Chicago Home Rule Commission. (1954). Modernizing a city government. Chicago: The University of Chicago Press.

Chicago Metropolitan Agency for Planning. (2013). Metropolitan Chicago's manufacturing cluster: a drill-down report on innovation, workforce, and infrastructure. Summary report, Februray 2013.

Chicago Metropolitan Agency for Planning. (2014). GO TO Metro 2040: plan update summary.

Chicago Metropolitan Agency for Planning. (2014). GO TO 2040. Retrieved from http://www.cmap.illinois.gov/about/2040

Chicago Metropolitan Agency for Planning. (2014). Plan update. Retrieved from http://www.cmap.illinois.gov/about/2040/update

Chicago Sister Cities' International. (2008). Accra-Chicago programs and events. Retrieved from http://old.chicagosistercities.com/cities/e_accra.php

Chicago Sister Cities International. (2013). Chicago Sister Cities International: mission. Retrieved from http://chicagosistercities.com/misson/

Chicago Sister Cities International. (2013). Sister Cities. Retrieved from http://chicagosistercities.com/sister-cities/

Choose Chicago. (n.d.). Foreign consulates. Retrieved from http://www.choosechicago.com/articles/view/FOREIGN-CONSULATES-/120/

City of Chicago. (2010-2013). City of Chicago: the city of Chicago's official site. Retrieved from http://www.cityofchicago.org/city/en/about.html

City of Chicago. (2013). The City of Chicago Technology Plan. Chicago, IL.

City of Chicago. (2010-2014). Mayor Emanuel announces final agreement for $\$ 900$ million Wanda Vista Hotel and Residence. Retrieved from http://www.cityofchicago.org/city/en/depts/mayor/press_room/press_releases/201 4/dec/mayor-emanuel-announces-final-agreement-for--900-million-wanda-v.html

Civic Consulting Alliance. (2015). Choose Chicago tourism market strategy. Retrieved from http://www.ccachicago.org/project/choose-chicago-tourism-market-strategy

Civic Consulting Alliance. (2015). Civic Consulting Alliance: about us. Retrieved from http://www.ccachicago.org/about/about-us

Civic Consulting Alliance. (2015). Civic Consulting Alliance: history. Retrieved from http://www.ccachicago.org/about/history

Civic Consulting Alliance. (2015). Civic Consulting Alliance: our work. Retrieved from http://www.ccachicago.org/our-work 
Civic Consulting Alliance. (n.d.). August 2011 update: Chicago's private sector invests more than $\$ 20$ million pro bono. Retrieved from http://archive.constantcontact.com/fs001/1102192544268/archive/110664123654 $0 . h t m l$

Cochrane, A., Peck, J., and Tickell, A. (1996). Manchester plays games: exploring the local politics of globalisation. Urban Studies, 33(8), 1319-1336.

Coleman, J. S., Pye, L. W., Weiner, M., Rustow, D. A., Blanksten, G. I., Almond, G. A. (1960). In G. A. Almond \& J. S. Coleman (Eds.) The politics of the developing areas. Princeton, New Jersey: Princeton University Press.

Corporation for a Skilled Workforce. (2003). The state of the workforce report for the metropolitan Chicago region. The Workforce Boards of Metropolitan Chicago.

Cox, K. (2004). Globalization and the politics of local and regional development: the question of convergence. Transactions of the Institute of British Geographers, 29(2), 179-194.

Cox, K. R. (1995). Globalisation, competition, and the politics of local economic development. Urban Studies, 32(2), 213-224. doi:10.1080/00420989550013059

Cox, K. R. (2010). The problem of metropolitan governance and the politics of scale. Regional Studies, 44(2), 215-227. doi:10.1080/00343400903365128

Cox, W. (2012). Local demography and townships in the Chicagoland area. Demographia.

Crook, R. C. (1994). Four years of the Ghana district assemblies in operation: decentralization, democratization, and administrative performance. Public Administration and Development, a journal of the Royal Institute of Public Admnistration, 14(4), 339-364.

Danso, A. (1991). Decentralization in Ghana: the case of the district assemblies. Southeastern Political Review, 19(1), 117-141.

Databank Financial Services. (2013-2014). About us. Retrieved from https://www.databankgroup.com/index.php?option=com_content\&view=article\&i $\mathrm{d}=83 \&$ Itemid $=76$

David, P. A. . (1985). Clio and the economics of QWERTY. American Economic Review, $75,332-337$.

Davies, J. (2007). Against "partnership": toward a local challenge to global neoliberalism. In R. Hambleton, \& J. S. Gross (Eds.), Governing cities in a global era: urban innovation, competition, and democratic reform (pp. 199-210). New York: Palgrave Macmillan. 
Davis, D. E. (2005, March). Cities in global context: a brief intellectual history. International Journal of Urban and Regional Research, 29(1), 92-109.

Demissie, F. (2006). Globalization and the remaking of Chicago. In J. P. Koval, L. Bennett, M. I. Bennett, F. Demissie, R. Garner, \& K. Kim (Eds.), The new Chicago: a social and cultural analysis (pp. 19-31). Philadelphia, PA: Temple University Press.

Denters, B. and Mossberger, K. (2006). Building blocks for a methodology for comparative urban political research. Urban Affairs Review, 4l(550). doi: $10.1177 / 1078087405282607$

Derksen, W. (1988). Municipal amalgamation and the doubtful relationship between size and performance. Local Government Studies, 14(6), 31-47.

DiGaetano, A. and Strom, E. (2003, January). Comparative urban governance: an integrated approach. Urban Affairs Review, 38(3), 356-395. doi: $10.1177 / 1078087402238806$

Dolan, D. (1990). Local government fragmentation: does it drive up the cost of government? Urban Affairs Quarterly, 26(1), 28-45.

Douglass, M. (2002, April). From global intercity competition to cooperation for livable cities and economic resilience in Pacific Asia. Environment and Urbanization, 14(1), 53-68.

Doussard, M., Peck, J., and Theodore, N. (2009). After deindustrialization: uneven growth and economic inequality in "postindustrial" Chicago. Economic Geography, 85(2), 183-207.

Drakakis-Smith, D. (2000). Third world cities (Second ed.). London \& New York: Routledge.

Easton, G. (2010). Critical realism in case study research. Industrial Marketing Management, 39, 118-128.

Edwin, B. J. and Gamble, D. (1984). City/county conolidation and economies of scale: evidence from a time-series analysis in Jacksonville, Florida. Social Science Quarterly, 65, 190-198.

Ehsan, M. and Naz, F. (2003, July-September). Origins, ideas, and practice of new public management: lessons from developing countries. Asian Affairs, 25(3), 30-48.

Eisenhardt, K.M. (2002). Building theories from case study research. In A. Huberman \& M. Miles, The qualitative researcher's companion (pp. 5-35). Thousand Oaks, London, and New York: Sage Publications.

Eisner, E. (1997). The new frontier in qualitative research methodology. Qualitative Inquiry, 3(259). doi:10.1177/107780049700300301 
Elander, I. (2002). Partnerships and urban governance. Blackwell Publishers.

Elkins, D. J. and Simeon, R. E. B. (1979, January). A cause in search of its effect, or what does political culture explain? Comparative Politics, 11(2), 127-145.

Ernst and Young. (2014). EY's attractiveness survey: Africa 2014 - executing growth.

Ewusi, K. (1973). Economic development planning in Ghana. New York: Exposition Press.

Fainstein, S and Harloe, M. (1992). Introduction: London and New York in the contemporary world. In S. Fainstein, I. Gordon, \& M. Harloe (Eds.), Divided cities (pp. 1-28). Oxford, UK: Blackwell.

Fairclough, N. (2005). Peripheral vision: discourse analysis in organization studies: the case for critical realism. Organization Studies, 26(6), 915-939. doi: $10.1177 / 0170840605054610$

Farvacque-Vitkovic, C., Raghunath, M., Eghoff, C., and Boakye, C. (2008). Development of the cities of Ghana: challenges, priorities, and tools. Africa Region Working Paper Series Number 110, The World Bank.

Feagin, J. R., Orum, A. M., \& Sjoberg, G. (Eds.). (1991). A case for the case study. Chapel Hill and London: The University of North Carolina press.

Feiock, R. (2007). Rational choice and regional governance. Journal of Urban Affairs, 29(1), 47-63.

Feiock, R. C. (2005). Institutional collective action and local governance. Working Group on Inter-Local Services Cooperation, Paper 5. Retrieved from http://digitalcommons.wayne.edu/interlocal_coop/5

Feiock, R. C. (2009, January). Metropolitan governance and institutional collective action. Urban Affairs Review, 44(3), 356-377. doi:10.1177/1078087408324000

Feiock, R. C., Moon, M. J., and Park, H. J. (2008, January/February). Is the world "flat" or "spiky"? Rethinking the governance implications of globalization for economic development. Public Administration Review, 24-35.

Feoick, R.C., Steinacker, A., and Park, H. J. (2009, March/April). Institutional collective action and economic development joint ventures. Public Admnistration Review.

Ferman, B. (1996). Challenging the growth machine: neighborhood politics in Chicago and Pittsburgh. Lawrence, Kansas: University Press of Kansas.

Ferrazzi, G. (2006). Ghana Local Government Act 1993: a comparative analysis in the context of the review of the act. Local Governance and Poverty Reduction Support Programme (LGPRSP), Ministry of Local Government, Rural Development and Environment/Deutsche Gesellschaft Für Technische Zusammenarbeit (GTZ). 
Fidel, K. (2006). The physical transformation of metropolitan Chicago: the emergent suburban landscape. In J. P. Koval, L. Bennett, M. I. Bennett, F. Demissie, R. Garner, \& K. Kim (Eds.), The new Chicago: a social and cultural analysis (pp. 77-81). Philadelphia, PA: Temple University Press.

Filstead, W. J. (Ed.). (1970). Qualitative method: firsthand involvement with the social world. Chicago: Markham Publishing Company.

Florida, R. (2002). The rise of the creative class: and how it's transforming work, leisure, community, and everyday life. New York: Basic Books.

Florida, R. (2005a). Cities and the creative class. New York \& London: Routeledge.

Florida, R. (2005b). The flight of the creative class: the new global competition for talent. New York: Harper Business.

Florida, R. (2005c, October). The world is spiky: globalization has changed the economic playing field, but hasn't leveled it. The Atlantic, 48-51.

Flyvbjerg, B. (2006). Five misunderstandings about case-study research. Qualitative Inquiry, 12(219). doi:10.1177/1077800405284363

Forbes, D. (n.d.). Reading texts and writing Geography. In I. Hay (Ed.), Qualitative research methods in Human Geography (pp. 122-142). Oxford: Oxford University Press.

Fortune (2013). Fortune 500 2013. Retrieved from http://fortune.com/fortune500/2013/navistar-international-corporation-216/

Fougner, T. (2008). Neoliberal governance of states: the role of competitiveness indexing and country benchmarking. Millenium - Journal of International Studies, 37(303). doi: $10.1177 / 0305829808097642$

Freeman, C. (2007). The "reputation" of neoliberalism. American Ethnologist, 34(2), 252-267. doi:10.1525/ae.2007.34.2.252

Friedman, J. (1986). The world city hypothesis. Development and Change, 69-83.

Frimpong Boamah E. and Amoako C. (2013). Regionalism and urban development planning in Africa: towards a collaborative framework for decentralized planning in Ghana. Developing Country Studies, 3(9), 142-155.

Frisken, F. and Norris, D. F. (2001). Regionalism reconsidered. Journal of Urban Affairs, 23(5), 467-478.

Fuchs, G. and Shapira, P. (2005, January). Rethinking regional innovation and change: path dependency or regional breakthrough? Economics of Science, Technology, and Innovation, 30.

Fuest, V. and Haffner, S. A. (2007). PPP - policies, practices and problems in Ghana's urban water supply. Water Policy, 9, 169-192. 
Gains, F., John, P. C., and Stoker, G. (2005). Path-dependency and the reform of the English local government. Public Administration , 83(1), 25-45.

Ga South Municipal Assembly. (2014). The composite budget of the Ga South District Assembly for the 2014 fiscal year. Retrieved from http://www.mofep.gov.gh/sites/default/files/budget/2014/GR/Ga_South.pdf

Ga West Municipal Assembly. (2006). About this municipality. Retrieved from: http://gawest.ghanadistricts.gov.gh/?arrow=atd\&_=1

Genoud, R. (1969). Nationalism and economic development in Ghana. New York, Washington, and London: Frederick A. Praeger.

Ghana Investment Promotion Center. (2007, April). The GIPC quarterly. First quarter 2007 investment report, 3(1).

Ghana Investment Promotion Center. (2007, June). The GIPC quarterly update. Second quarter 2007 investment report, 3(2).

Ghana Investment Promotion Center. (2007, October). The GIPC quarterly update. Third quarter 2007 investment report, 3(3).

Ghana Investment Promotion Center. (2008, April). The GIPC quarterly update. First quarter 2008 investment report, 4(1).

Ghana Investment Promotion Center. (2008, January). The GIPC quarterly update. Fourth quarter 2007 investment report, 3(4).

Ghana Investment Promotion Center. (2008, July). The GIPC quarterly update. Second quarter 2008 investment report, 4(2).

Ghana Investment Promotion Center. (2008, October). The GIPC quarterly update. Third quarter 2008 investment report, 4(3).

Ghana Investment Promotion Center. (2009). The GIPC quarterly update. First quarter 2009 investment report, 5(1).

Ghana Investment Promotion Center. (2009). The GIPC quarterly update. Third quarter 2009 investment report, 5(3).

Ghana Investment Promotion Center. (2009, August). The GIPC quarterly update. Second quarter 2009 investment report, 5(2).

Ghana Investment Promotion Center. (2009, January). The GIPC quarterly update. Fourth quarter 2008 investment report, 4(4).

Ghana Investment Promotion Center. (2010). The GIPC quarterly update. Fourth quarter 2009 investment report, 5(4).

Ghana Investment Promotion Center. (2010, April). The GIPC quartely update. First quarter 2010 investment report, 6(1). 
Ghana Investment Promotion Center. (2010, July). The GIPC quarterly update. Second quarter 2010 investment report, 6(2).

Ghana Investment Promotion Center. (2010, October). The GIPC quarterly update. Third quarter 2010 investment report, 6(3).

Ghana Investment Promotion Center. (2011, April). The GIPC quarterly update. First quarter 2011 investment update, 7(1).

Ghana Investment Promotion Center. (2011, January). The GIPC quarterly update. Fourth quarter 2010 investment report, 6(4).

Ghana Investment Promotion Center. (2011, July). The GIPC quarterly update. Second quarter 2011 investment update, 7(2).

Ghana Investment Promotion Center. (2011, October). The GIPC quarterly update. Third quarter 2011 investment report, 7(3).

Ghana Investment Promotion Center. (2012, April). The GIPC quarterly update. First quarter 2012 investment report, 8(1).

Ghana Investment Promotion Center. (2012, January). The GIPC quarterly update. Fourth quarter 2011 investment report, 7(4).

Ghana Investment Promotion Center. (2012, July). The GIPC quarterly update. Second quarter 2012 investment report, 8(2).

Ghana Investment Promotion Center. (2012, October). The GIPC quarterly update. Third quarter 2012 investment report, 8(3).

Ghana Investment Promotion Center. (2013). Ghana Investment Promotion Center Act, 2013: Act 865 .

Ghana Investment Promotion Center. (2013, April). The GIPC quarterly update. First quarter 2013 investment report, 9(1).

Ghana Investment Promotion Center. (2013, January). The GIPC quartely update. Fourth quarter 2012 investment report, 8(4).

Ghana Investment Promotion Center. (2013, July). The GIPC quarterly update. Second quarter 2013 investment report, 9(2).

Ghana Investment Promotion Center. (2013, October). The quarterly update. Third quarter 2013 investment report, 9(3).

Ghana Investment Promotion Center. (2014, January). GIPC Quarterly update. Fourth quarter 2013 investment report, 9(4).

Ghana Land Administration Project. (n.d.). Background of AMA. Retrieved from http://www.ghanalap.gov.gh/index.php/implementing-agencies/accrametropolitan-assembly 
Ghana Statistical Service. (2012). 2010 population and housing census: final results. Ghana Statistical Service.

Ghana Statistical Service. (2014). 2010 population and housing census: district analytic report - Adentan Municipality. Retrieved from http://www.statsghana.gov.gh/docfiles/2010_District_Report/Greater\%20Accra/A dentan.pdf

Ghana Statistical Service. (2014). 2010 population and housing census: district analytic report - Ashaiman Municipality. Retrieved from http://www.statsghana.gov.gh/docfiles/2010_District_Report/Greater\%20Accra/A SHAIMAN\%20MUNICIPAL.pdf

Ghana Statistical Service. (2014). 2010 population and housing census: district analytic report - Ga East Municipality. Retrieved from http://www.statsghana.gov.gh/docfiles/2010_District_Report/Greater\%20Accra/G A\%20EAST.pdf

Ghana Statistical Service. (2014). 2010 population and housing census: district analytic report - Ga South Municipality. Retrieved from http://www.statsghana.gov.gh/docfiles/2010_District_Report/Greater\%20Accra/G A\%20SOUTH.pdf

Ghana Statistical Service. (2014). 2010 population and housing census: district analytic report - Ga West Municipality. Retrieved from http://www.statsghana.gov.gh/docfiles/2010_District_Report/Greater\%20Accra/G A\%20WEST.pdf

GhanaWeb. (1994-2014). Diplomatic missions in Ghana. Retrieved from http://www.ghanaweb.com/GhanaHomePage/foreign_affairs/home.php

GhanaWeb. (1994-2014). International organizations in ghana. Retrieved from http://www.ghanaweb.com/GhanaHomePage/foreign_affairs/org.php

Gibbs, D. and Jonas, A. E. G. (2001). Rescaling and regional governance: the English Regional Development Agencies and the environment. Environment and Planning C: Government and Policy, 19, 269-288. doi:10.1068/c9908j

Gillette, C. P. (2001, April). Regionilization and inter-local bargains. New York University Law Review, 76, 190.

Gissendanner, S. (2004). Mayors, governance coalitions, and strategic capacity: drawing lessons from Germany for theories of urban governance. Urban Affairs Review, 40(44). doi:10.1177/1078087404267188

Giulianotti, R. and Robertson, R. (2007). Forms of glocalization: globalization and the migration strategies of Scottish football fans in North America. Sociology, 4l(1), 133-152. 
Glaeser, E. (2011). Triumph of the city: how our greatest invention makes us richer, smarter, greener, healthier, and happier. New York: The Penguin Press.

GoAbroad.com. (1998-2014). Foreign embassies and consulates in Ghana. Retrieved from http://embassy.goabroad.com/embassies-in/ghana

Goldfrank, B. and Schrank, A. (2009, June). Municipal neoliberalism and municipal socialism: urban political economy in Latin America. International Journal of Urban and Regional Research, 33(2), 443-462. doi:10.1111/j.14682427.2009.00834.x

Golubchikov, O. (2004). Urban planning in Russia: towards the market. European Planning Studies, 12(2), 229-247.

Gough, K. (1999, November). The changing nature of urban governance in peri-urban Accra, Ghana. Third World Planning Review, 21(4).

Government of Canada. (2014). The Canadian trade commissioner service. Retrieved from http://www.tradecommissioner.gc.ca/eng/trademissions/document.jsp?did=126829

Government of Ghana: Ministry of Local Government and Rural Development. (2010). Draft decentralization policy framework. Theme: accelerating decentralization and local governance for national development.

Government of Ghana: Ministry of Local Government and Rural Development. (2012). Ghana National Urban Policy Action Plan.

Government of Ghana Official Portal. (2014). Greater Accra. Retrieved from http://www.ghana.gov.gh/index.php/about-ghana/regions/greater-accra

Grant, R. (2001). Liberalization policies and foreign companies in Accra, Ghana. Environment and Planning A , 33, 997-1014. doi:10.1068/a33144

Grant, R. (2009). Globalizing city: the urban and economic transformation of Accra, Ghana. Syracuse, New York: Syracuse University Press.

Grant, R. and Nijman, J. (2002). Globalization and the corporate geography of cities in the less-developed world. Annals of the Association of American Geographers, 92(2), 320-340.

Grant, R. and Nijman, J. (2004). The rescaling of uneven development in Ghana and India. Tijdschrift voor Economische en Sociale Geografie, 95(5), 467-481.

Grant, R. and Yankson, P. (2002). City profile: Accra. Cities, 20(1), 65-74.

Great Cities Institute. (2001). Metropolitan decentralization in Chicago. Chicago Case Study Working Group of the Great Cities Institute. 
Grossman, R. (2004). Global city, global people. In C. Madigan (Ed.), Global Chicago (pp. 94-117). Urbana and Chicago: Chicago Council on Foreign Relations and the University of Illinois Press.

Gruening, G. (2001). Origin and theoretical basis of new public management. International Public Mangement Journal, 4, 1-25.

Gyimah-Boadi, E. (1990). Economic recovery and politics in PNDC's Ghana. The Journal of Commonwealth and Comparative Politics, 28(3), 328-343.

G4S. (n. d.). "Who we are". Retrieved from http://www.g4s.com/en/Who\%20we\%20are/

Hackworth, J. (2007). The neoliberal city: governance, ideology, and development in American urbanism. Ithaca and London: Cornell University Press.

Hambleton, R. \& Gross, J. (Eds.). (2007). Governing cities in a global era: urban innovation, competition, and democratic reform. Palgrave Macmillan.

Hamilton, D. K. (2002, Spring). Regionalism in metropolitan Chicago: a work in progress. National Civic Review, 91(1), 63-80.

Hamilton, D. K. (2004a). Developing regional regimes: a comparison of two metropolitan areas. Journal of Urban Affairs, 26(4), 455-477.

Hamilton, D. K. (2004b). The government centralization-decentralization debate in metropolitan areas. Review of Policy Research, 21(5), 663-680.

Hamilton, D. K., Miller, D. Y., and Paytas, J. (2004, November). Exploring the horizontal and vertical dimensions of the governing of metropolitan regions. Urban Affairs Review, 40(2), 147-182.

Han, J., Liu, R., and Zhang, J. (2012). Globalization and wage inequality: evidence from urban China. Journal of International Economics, 87, 288-297.

Harloe, M. and Fainstein, S. S. (1992). Conclusion: the divided cities. In S. Fainstein, I. Gordon, \& M. Harloe (Eds.), Divided cities (pp. 236-268). Oxford, UK: Blackwell.

Haruna, P. F. (2003, May/June). Reforming Ghana's public service: issues and experiences in comparative perspective. Public Administration Review, 63(3).

Haruna, P. F. (2004, June). Rethinking administrative globalization: promises, dilemmas, and lessons in Ghana. Administrative Theory \& Praxis, 26(2), 185-212. Retrieved from http://www.jstor.org/stable/25610665

Hastings, A. (1999a). Discourse and urban change: introduction to the special issue. Urban Studies, 36(1), 1-12. doi:10.1080/004098993691

Hastings, A. (1999b). Analysing power relations in partnerships: is there a role for discourse analysis? Urban Studies, 36(1), 91-106. doi:10.1080/0042098993754 
Haynes, J. (1991). The PNDC and political decentralisation in Ghana, 1981-1991. The Journal of Commonwealth and Comparative Politics, 29(3), 283-307.

Heinrich, C. (2002, November/December). Outcomes-based performance management in the public sector: implications for government accountability and effectiveness. Public Administration Review, 62(6).

Held, D. (2000). Regulating globalization? The reinvention of politics. International Sociology, 15(2), 394-408. doi:10.1177/0268580900015002015

Held, D. and Mcgrew, A. (2003). Political globalization: trends and choices. In I. Kaul, P. Conceicao, K. L. Goulven, \& R. U. Mendoza (Eds.), Providing global public goods: managing globalization (pp. 185-199). Oxford University Press, Inc.

Henderson, H. (1988). Urban development. New York \& Oxford: Oxford University Press, Inc.

Hendrick-Wong, Y. and Angelopulo, G. (n.d.). 2014 MasterCard African cities growth index: understanding inclusive urbanization. MasterCard.

Herbert, S. (2000). For ethnography. Progress in Human Geography, 24(4), 550-568.

Herbst, J. (1993). The politics of reform in Ghana: 1982-1991. Berkeley, Los Angeles, \& Oxford: University of Califfornia Press.

Hitchings, B. (1998). A typology of regional growth management systems. The Regionalist, 3(1 \& 2), 1-14.

Horwath HTL. (2011). Special Market Report: Accra, Ghana. Issue 2.

Huberman, A. M. and Miles, M. B. (2002). The qualitative researcher's companion. Thousand Oaks, London, and New Delhi: Sage Publications: International Educational and Professional Publisher.

4International Colleges and Universities. (2005-2013). Universities in Ghana. Retrieved from http://www.4icu.org/gh/

Illinois Department of Commerce and Economic Opportunity. (2014). The Illinois economic development plan.

Inglehart, R. (1998, December). The renaissance of political culture. The American Political Science Review, 82(4), 1203-1230. Retrieved from http://www.jstor.org/stable/1961756

Inglehart, R. (2000). Globalization and postmodern values. The Washington Quarterly, 23(1), 215-228. doi:10.1162/016366000560665

Jacobs, A. (2004). Inter-local relations and divergent growth: the Detroit and Tokai Auto regions, 1969 to 1996. Journal of Urban Affairs, 26(4), 479-504. 
Jacobs, J. (1984). Cities and the wealth of nations: principles of economic life. New York: Vintage Books.

Johnson, E. W. (1999). Chicago Metropolis 2020: preparing metropolitan Chicago for the 21st century. Commercial Club of Chicago and the American Academy of Arts \& Sciences.

Johnson, R. A. (2005). Privatization. Retrieved from The electronic encyclopedia of Chicago: http://www.encyclopedia.chicagohistory.org/pages/1011.html

Joint Committee on City-County Collaboration. (2012, February). Final report. Retrieved from http://www.ccachicago.org/sites/default/files/120206_FinalReport_0.pdf

Jonas, A. E. G. and Pincetl, S. (2006). Rescaling regions in the state: the new regionalism in California. Political Geography , 25, 482-505.

Jonas, A. E. G. and Ward, K. (2002). A world of regionalisms? Towards a US-UK urban and regional policy framework comparison. Journal of Urban Affairs, 24(4), 377401.

Jones, M. and MacLeod, G. (1999). Towards a regional renaissance? Reconfiguring and rescaling England's economic governance. Transactions of the Institute of British Geographers, 295-313.

Jung, C. and Kim, J. (2009, May). Patterns and the determinants of inter-local cooperation in American cities and counties. International Review of Public Administration, 14(1), 11-25.

Kacowicz, A. (1998, December). Regionalization, globalization, and nationalism: convergent, divergent, or overlapping? Working Paper \#262, The Helen Kellogg Institue for International Studies.

Kantor, P. and Savitch, H. V. (2005, March). How to study comparative urban development politics: a research note. International Journal of Urban and Regional Research, 29(1), 135-151.

Kaplan, R. D. (1999, December). Could this be the new world? . New York Times, 27, A23. Retrieved from http://www.nytimes.com/1999/12/27/opinion/could-this-bethe-new-world.html

Kaplan, R. D. (2000). The coming anarchy: shattering the dreams of the post Cold War. New York: Vintage.

Katz, B. and Bradley, J. (1999). Divided we sprawl. The Atlantic Monthly, 284(6), 26-34.

Keating, M. (1997). The invention of regions: political restructuring and territorial government in Western Europe. Environment and Planning C: Government and Policy, 15, 383-398. 
Kessides, C. (2005). The urban transition in sub-Saharan Africa: implications for economic growth and poverty reduction. Africa Region: Working Paper Series Number 97, The World Bank, Urban Development Unit, Transportation and Urban Development Department.

Keum, H. (2000, Summer). Globalization and inter-city cooperation in Northeast Asia. East Asia, 18(2), 97-114.

King, A. (1992). Urbanism, colonialism and the world-economy. In The blackwell city reader (pp. 365-373).

King, A. D. (1976). Colonial urban development: culture, social power, and environment. London and Boston: Routledge and Kegan Paul.

Kirkman, R. (2010, Spring). Did Americans choose sprawl? Ethics and the Environment, 15(1), 123-142.

Knox, P. L. (1997, May). Globalization and urban economic change. Annals of the American Academy of Political and Social Science, 551, 17-27.

Knuth, M. (2009). Path shifting and path dependence: labor market policy reforms under German federalism. International Journal of Public Administration, 32(12), 10481069. doi:10.1080/01900690903135934

Koerner, W. (1968). Inter-local cooperation: the Missouri approach. Missouri Law Review, 33(442).

Konadu-Agyemang, K. (2001). The political economy of housing and urban development in Africa: Ghana's experience from colonial times to 1998. Westport, Connecticut \& London: Praeger Publishers.

Koval, J. P. (2006). An overview and point of view. In J. P. Koval, L. Bennett, M. I. Bennett, F. Demissie, R. Garner, \& K. Kim (Eds.), The new Chicago: A social and cultural analysis (pp. 3-15). Philadelphia, PA: Temple University Press.

Koval, J. P. and Fidel, K. (2006). Chicago: the immigrant capital of the heartland. In J. P. Koval, L. Bennett, M. I. Bennett, F. Demissie, R. Garner, \& K. Kim (Eds.), The new Chicago: A social and cultural analysis (pp. 97-104). Philadelphia, PA: Temple University Press.

Laryea-Adjei, G. (2000). Building capacity for urban management in Ghana: some critical considerations. Habitat International, 24, 391-401.

Ledzokuku-Krowor Municipal Assembly. (2015). The composite budget of the Ledzokuku-Krowor District Assembly for the 2015 fiscal year. Retrieved from http://www.mofep.gov.gh/sites/default/files/budget/2015/Composite/GR/Ledzork uku-Krowor.pdf 
Le Gales, P. (2001). Urban governance and policy networks: on the urban political boundedness of policy networks - A French case study. Public Administration, 79(1), 167-184.

Lee, S.-W. and Ducruet, C. (2009). Spatial glocalization in Asia-Pacific hub port cities: a comparison of Hong Kong and Singapore. Urban Geography, 30(2), 162-184.

LeGates, R.T. and Stout, F. (2011). The city reader. London \& New York: Routledge: Taylor \& Francis Group.

Levin Institute - The State University of new York. (2014). Globalization 101: A Project of SUNY Levin Institute. Retrieved from What is Globalization?: http://www.globalization101.org/what-is-globalization/

Li, Y. and Wu, F. (2012). The transformation of regional governance in China: the rescaling of statehood. Progress in Planning, 78, 55-99.

Liebowitz, S.J. and Margolis, S.E. (1995, April). Path dependence, lock-in, and history. Journal of Law, Economics, \& Organization, 11(1), 205-226. Retrieved from http://www.jstor.org/stable/765077

Lindblom, C. (1977). Politics and markets: the world's political economic systems. New York: Basic Books, Inc., Publishers.

Lindstrom, B. (1998). Regional cooperation and sustainable growth: nine councils of government in Northeastern Illinois. Journal of Urban Affairs, 20(3), 327-342.

Lindstrom, B. (1999). The role of regional planning agencies in suburban deconcentration. Great Cities Institute working paper.

Lindstrom, B. (2010). The Metropolitan Mayors Caucus: institution building in a politically fragmented metropolitan region. Urban affairs Review, 46(1), 37-67.

Lindstrom, B. (2014). Regional governance: Chicago style. 2014 Conference of the Urban Affairs Association. San Antonio, TX.

Linsky, A. S. (1965, September). Some generalizations concerning primate cities. Annals of the Association of American Geographers, 55(3), 506-513.

Local Government Service. (2013). About local government. Retrieved from http://www.lgs.gov.gh/about-local-government

Longworth, R. C. (2004). The political city. In C. Madigan (Ed.), Global Chicago (pp. 70-93). Urbana and Chicago: Chicago Council on Foreign Relations and the University of Illinois Press.

Loughborough University. (2015). The world according to GAWC. Retrieved from http://www.lboro.ac.uk/gawc/gawcworlds.html

Louisin, A. (1988). The 1970 Illinois Constitution: has it made a difference? The John Marshall Law School - The John Marshall Institutional Repository. 
MacLeod, G. (2001, December). New regionalism reconsidered: globalization and the remaking of political economic space. International Journal of Urban and Regional Research, 25(4).

Macleod, G. and Goodwin, M. (1999). Space, scale and state strategy: rethinking urban and regional governance. Progress in Human Geography, 23(4), 503-527. doi:10.1191/030913299669861026

Madigan, C. (Ed.). (2004). Global Chicago. Urbana and Chicago: University of Illinois Press.

Madon, S. and Sahay, S. (2001). Cities in the developing world: linking global and local networks. Information Technology \& People, 14(3), 273-286.

Marcum, J. (2005). Thomas Kuhn's revolution. London \& New York: University of Chicago Press.

Marcuse, P. (1993). What's so new about divided cities. International Journal of Urban and Regional Research, 17(3), 355-365.

Martin, R. and Sunley, P. (2006). Path dependence and regional economic evolution. Journal of Economic Geography, 6, 395-437.

Martin, R. (2010). Roepke lecture in Economic Geography - rethinking regional path dependence: beyond lock-in to evolution. Economic Geography, 86(1), 1-27.

Matkin, D. S. and Frederickson,. (2009). Metropolitan governance: institutional roles and inter-jurisdictional competition. Journal of Urban Affairs, 31(1), 45-66.

Mayfield, L. (2005). Government, city of Chicago. Retrieved from The Electronic Encyclopedia of Chicago:

http://www.encyclopedia.chicagohistory.org/pages/532.html

McCann, P. (2008). Globalization and economic geography: the world is curved, not flat. Cambridge Journal of Regions, Economy and Society, 1, 351-370. doi:10.1093/cjres/rsn002

McCann, P. and Acs, Z. J. (2011). Globalization: countries, cities and multinationals. Regional Studies, 45(1), 17-32. doi:10.1080/00343404.2010.505915

McDan Shipping Company Limited. (n. d.). "About McDan". Retrieved from http://www.mcdanshipping.com/index.php?option=com_content\&view=article\&i $\mathrm{d}=47$ \&Itemid $=53$

Meier, K. J. and O'Toole, L. J. (2002, Fall). Public management and organizational performance: the impact of managerial quality. Journal of Policy Analysis and Management.

Merrill, M. (1970, November). Our unrealized resource: Inter-municipal cooperation. Oklahoma Law Review, 23(4). 
Metropolitan Planning Council. (2014). Reinventing the region: 2014 plan for prosperity. Retrieved from

http://www.metroplanning.org/uploads/cms/documents/2014_mpc_plan_for_pros perity.pdf

Metropolitan Planning Council. (2015). About MPC. Retrieved from http://www.metroplanning.org/about/index.html

Metropolis Strategies. (2011). Restoring Chicago's momentum: a regional agenda for economic growth.

Metropolis Strategies. (n.d.). Recent accomplishments and priorities. Retrieved from http://www.metropolisstrategies.org/metropolis-strategies-accomplishments.html

Metropolis Strategies. (n.d.). What is Metropolis Strategies? Retrieved from http://www.metropolisstrategies.org/what-is-metropolis-strategies.html

Meyer-Stamer, J. (1998). Path dependence in regional development: persistence and change in three industrial clusters in Santa Catarina, Brazil. World Development, 26(8), 1495-1511.

Miller, D. Y. (2002). The regional governing of metropolitan America. Cambridge, MA: Westview Press, a member of the Perseus Books Group.

Miller, D. R. (2005). 1970 Illinois Constitution: annotated for legislators. Fourth edition: publication 314.

Millennium Cities Initiative, Earth Institute - Columbia University. (2011). Addressing urban poverty in sub-Saharan Africa: an overview of the Millennium Cities Initiative.

Millennium Cities Initiative: Earth Institue - Columbia University. (n.d.). Background, objectives, and methodology. Retrieved from

http://mci.ei.columbia.edu/millennium-cities/accra-ghana/background-objectivesmethodology/

Ministry of Food and Agriculture - Republic of Ghana. (2015). Districts - Greater Accra. Retrieved from http://mofa.gov.gh/site/?page_id=1561

Ministry of Food and Agriculture - Republic of Ghana. (2015). Tema Municipal: introduction. Retrieved from http://mofa.gov.gh/site/?page_id=1577

Ministry of Local Government \& Rural Development and Maks Publications \& Media Services. (2006). Greater Accra: Accra Metropolitan - administrative and institutional arrangements. Retrieved from

http://www.ghanadistricts.com/districts/?r=1\&_=3\&sa=3037

Ministry of Local Government \& Rural Development and Maks Publications \& Media Services. (2006). Greater Accra: Accra Metropolitan - boundary and 
administrative area. Retrieved from

http://www.ghanadistricts.com/districts/?r=1\&_=3\&sa $=3055$

Ministry of Local Government \& Rural Development and Maks Publications \& Media Services. (2006). Greater Accra: Accra Metropolitan - metro finance. Retrieved from http://www.ghanadistricts.com/districts/?r=1\&_=3\&sa=3032

Ministry of Local Government \& Rural Development and Maks Publications \& Media Services. (2006). Greater Accra: Ga Central (new). Retrieved from $\mathrm{http}: / / \mathrm{www}$.ghanadistricts.com/districts/?news\&r=1\&_=213

Ministry of Local government \& Rural Development and Maks publications \& Media Services. (2006). Greater Accra; Ga East Municipal - Governance. Retrieved from http://www.ghanadistricts.com/districts/?r=1\&_=2\&sa $=6341$

Ministry of Local Government \& Rural Development and Maks Publications \& Media Services. (2006). Greater Accra: Ga West Municipal. Retrieved from http://ghanadistricts.com/districts/?news\&r=1\&_=1

Ministry of Local Government \& Rural Development and Maks Publications \& Media Services. (2006). Greater Accra: Ledzokuku-Krowor Municipal - administrative arrangements. Retrieved from http://www.ghanadistricts.com/districts/?r=1\&_=168\&sa $=5859$

Ministry of Local Government \& Rural Development and Maks Publications \& Media Services. (2006). Greater Accra. Retrieved from http://www.ghanadistricts.com/region/?r=1

Ministry of Local Government \& Rural Development and Maks Publications \& Media Services. (2006). Greater Accra: Tema Metropolitan. Retrieved from http://ghanadistricts.com/districts/?news\&r=1\&_=4

Ministry of Local Government \& Rural Development and Maks Publications \& Media Services. (2006). NATIONAL: Accept new districts- President advises. Retrieved from http://ghanadistricts.com/news/?read=13110

Mittelman, J. (Ed.). (1996). Globalization: critical reflections. Boulder, CO: Lynne Rienner.

Moberg, D. (1997, Spring). Chicago: to be or not to be a global city. World Policy Journal, 14(1), 71-86.

Moberg, D. (2006). Economic restructuring: Chicago's precarious balance. In J. P. Koval, L. Bennett, M. I. Bennett, F. Demissie, R. Garner, \& K. Kim (Eds.), The new Chicago: a social and cultural analysis (pp. 32-43). Philadelphia, PA: Temple University Press.

Mohan, G. (1996a). Adjustment and decentralization in Ghana: a case of diminished sovereignty. Political Geography, 15(1), 75-94. 
Mohan, G. (1996b). Neoliberalism and decentralized development planning in Ghana. Third World Planning Review, 18(4), 433-454.

Moore, D. (2001). Neoliberal globalisation and the triple crisis of modenization in Africa: Zimbabwe, the Democratic Republic of Congo, and South Africa. Third World Quarterly, 22(6), 909-929. doi:10.1080/01436590120099713

Moskow, M. H. (2004). Shaping global Chicago. In C. Madigan (Ed.), Global Chicago (pp. 191-207). Urbana and Chicago: Chicago Council on Foreign Relations and the University of Illinois Press.

Moskow, M. H. and Osborn, W. A., co-chairs. (2012). Foreign direct investment: globalizing Chicago's economic development plans. Report of an independent study group, Sponsored by The Chicago Council on Global Affairs.

National Development Planning Commission. (2011). The implementation of the Ghana Shared Growth and Development Agenda (GSGDA), 2010-2013. 2010 annual progress report.

National Development Planning Commission. (2015a). History of NDPC. Retrieved from http://www.ndpc.gov.gh/about/\#

National Development Planning Commission. (2015b). Introduction to NDPC. Retrieved from http://www.ndpc.gov.gh/about

Nelles, J. and Durand F. (2014). Political rescaling and metropolitan governance in crossborder regions: comparing the cross-border metropolitan areas of Lille and Luxembourg. European Urban and Regional Studies, 21(1), 104-122. doi: $10.1177 / 0969776411431103$

Newmont. (2014). Newmont: about us. Retrieved from http://www.newmont.com/aboutus/default.aspx

Nivola, P. (1999). Laws of the landscape: how policies shape cities in Europe and America. Washington, D.C.: Brookings Institution Press.

Norris, D. F. (2001, March). Whither metropolitan governance? Urban Affairs Review, $36(4), 532-550$.

Nyendu, M. (2012, April). Democratic decentralization in Ghana: the need for a policy review. Journal of Asian and African Studies, 47(2), 221-235.

Odame Larbi, W. (1996, May). Spatial planning and urban fragmentation in Accra. Third World Planning Review, 193-215.

Office of Foreign Missions: U.S. Department of State. (2001). 2001 annual report.

Ohemeng, F. (2010). The dangers of internationalization and "one-size-fits-all" in public sector management: lessons from performance management policies in Ontario 
and Ghana. International Journal of Public Sector Management, 23(5), 456-478. Retrieved from http://dx.doi.org/10.1108/09513551011058484

Okoye, V., Sands, J., and Debrah, C. A. (2010). The Accra Pilot Bus-Rapid Transit Project: transport land use research study. Millennium Cities Initiative: The Earth Institute at Columbia University.

Olberding, J. C. (2002). Diving into the "third waves" of regional governance and economic development strategies: a study of regional partnerships for economic development in U.S. metropolitan areas. Economic Development Quarterly, 16(3), 251-272. doi:10.1177/089124240201600305

Olowu, D. and Wunsch, S. (2004). Local governance in Africa: the challenges of democratic decentralization. Boulder, Colorado \& London: Lynne Rienner Publishers, Inc.

Orum, A. (2005). Governing the metropolis. Retrieved from The Electronic Encyclopedia of Chicago: http://www.encyclopedia.chicagohistory.org/pages/531.html

Osborne, D. and Gaebler, T. (1992). Reinventing government: how the entrepreneural spirt is transforming the public sector. Reading, Massachuussets; Menlo Park, California; New York; Don Mills, Ontario; Wokingham, England; Amsterdam; Bonn; Sydney; Singapore; Tokyo; Madrid; San Juan; Paris; Seoul; Milan; Mexico City; Taipei: Addison Wesley Publishing Company, Inc.

Ostrom, E. (2000, March). The danger of self-evident truths. PS: Poltical Science and Politics, 1-13.

Oteng-Ababio, M. (2010). Private sector involvement in solid waste management in the Greater Accra Metropolitan Area in Ghana. Waste Management \& Research, 28, 322-329.

Oteng-Ababio, M. (2011). The role of the informal sector in solid waste management in the GAMA, Ghana: challenges and opportunities. Tijdschrift voor Economische en Sociale Geografie, 103(4), 412-425.

Otoo, E.A., Whyatt, D.J., and Ite, U.E. (2006). Quantifying urban growth in Accra Metropolitan Area (AMA), Ghana and exploring causal mechanisms. Promoting Land Administration and Good Governace: 5th FIG Regional Conference, (pp. 18). Accra, Ghana.

Owusu, M. (1996, June). Tradition and transformation: democracy and the politics of popular power in Ghana. Journal of Modern African Studies, 34(2), 307-343.

Owusu, G. (2009). Internal boundaries: a challenge to decentralization and district development in Ghana. Swedish Society for Anthropology and Geography, 57-71.

Patomäki, H. and Wight, C. (2000). After postpositivism? The promises of critical realism. International Studies Quarterly, 44, 213-237. 
Peck, J. and Tickell, A. (2002). Neoliberalizing space. Antipode, 380-404.

Peters, B.G. and Pierre, J. (2001). Developments in inter-governmental relations: towards multi-level governance. Policy and Politics, 29(2), 131-135.

Peterson, P. (1981). City limits. Chicago \& London: The University of Chicago Press.

Pierre, J. (2005). Comparative urban governance: uncovering complex causalities. Urban Affairs Review, 40(4), 446-462. doi:10.1177/1078087404273442

Pierson, P. (2000a). Increasing returns, path dependence, and the study of politics. American Political Science Review, 94(2), 251-267. Retrieved from http://www.jstor.org/stable/2586011

Pierson, P. (2000b). Not just what but when: timing and sequencing in political processes. Studies in American Political Development, 14, 72-92.

Pierson, P. (2000c). The limits of design: explaining institutional origins and change. Governance, 13, 474-499.

Purcell, M. (2001). Metropolitan political reorganization as a politics of urban growth: the case of San Frnacisco Valley secession. Political Geography, 20, 613-633.

Rakodi, C. (1997). Global forces, urban change, and urban management in Africa. In C. E. Rakodi, The urban challenge in Africa: growth and management of its large cities (pp. 17-73). Tokyo, New York, and Paris: United Nations University Press.

Rakodi, C. (Ed.). (1997). The urban challenge in Africa: growth and mangement of its large cities. Tokyo, New York, \& Paris: United Nations University Press.

Rast, J. (1999). Remaking Chicago: the political origins of urban industrial change. DeKalb: Northern Illinois University Press.

Regional Transportation Authority. (2013). Regional transit strategic plan: 2013-2018.

Regional Transportation Authority. (2014). Retrieved from Overview and history: http://www.rtachicago.com/about-the-rta/overview-history-of-the-rta.html

Republic of Ghana. (1993). Local Government Act, Act 462. Accra: Assembly Press, Ghana Publishing Corporation.

Republic of Ghana. (1992). Constitution of the Republic of Ghana, 1992. Accra: Assembly Press, Ghana Publishing Corporation.

Richardson, L. (2000). Evaluating ethnography. Qualitative Inquiry, 6(2), 253-255.

Ritzer, G. (1999). Enchanting a disenchanted world. Thousand Oaks, California: Pine Forge Press.

RLG. (2014). "About $R L G$ ". Retrieved from http://www.rlgglobal.com/about-rlg/ 
Röber, M. and Schröter, E. (2007). Governing the capital: comparing institutional reform in Berlin, London, and Paris. In R. Hambleton, \& J. S. Gross (Eds.), Governing cities in a global era: urban innovation, competition, and democratic reform (pp. 33-44). Palgrave Macmillan.

Robertson, R. (1992). Globalization: Social Theory and Global Culture. London: Sage.

Robertson, R. (1994). Globalisation or Glocalisation? Journal of International Communication, 1(1), 33-52.

Martin, R. (2009). Rethinking regional path dependence: beyond lock-in to evolution. Economic Geography, 86(1), 1-27.

Rose, G. (1997). Sitauting knowledges: positionality, reflexivity, and other tactics. Progress in Human Geography, 21(3), 305-320.

Rose, G. (2001). Visual methodologies: an introduction to the interpretation of visual materials. London, Thousand oaks, and New Delhi: Sage Publications.

Ryner, M. (1999). Neoliberal globalization and the crisis of Swedish social democracy. Economic and Industrial Democracy. doi:10.1177/0143831X99201003

Saha, D., Fikri, K., and Marchio, N. (2014). FDI in U.S. metro areas: the geography of jobs in foreign-owned establishments. Washington D.C.: Brookings.

Sandelowski, M. (2000). Focus on research methods: whatever happened to qualitative description? Research in Nursing and Health, 23, 334-340.

Sassen, S. (1996). Cities and communities in the global economy. In N. Brenner \& R. Keil (Eds.), The global cities reader (pp. 82-88). London and New York: Routledge.

Sassen, S. (2000, January/March). New frontiers facing urban sociology at the millenium. British Journal of Sociology, 51(1), 143-159.

Sassen, S. (2001). The global city (Second ed.). Princeton \& Oxford: Princeton University Press.

Sassen, S. (2002). Locating cities on global circuits. In N. Brenner \& R. Keil, Eds. (2006), The global cities reader (pp. 89-95). London and New York: Routledge: Taylor \& Francis Group.

Sassen, S. (2003). Globalization or denationalization? Review of International Political Economy, 10(1), 1-22. doi:10.1080/0969229032000048853

Sassen, S. (2004). A global city. In C. Madigan (Ed.), Global Chicago (pp. 15-34). Urbana and Chicago: Chicago Council on Foreign Relations and the University of Illinois Press.

Sassen, S. (2012, Spring/Summer). Urban capabilities: an essay on our challenges and differences. Journal of International Affairs, 65(2), 85-95. 
Savitch, H. V. (2002). What is new about globalization and what does it portend for cities? International Social Science Journal, 179-189.

Savitch, H.V. and Kantor, P. (2002). Cities in the international marketplace: the political economy of urban development in North America and Western Europe. Princeton \& Oxford: Princeton University Press.

Savitch, H.V. and Vogel, R.K. (2000). Introduction: paths to new regionalism. State and Local Government Review, 32(3), 130-157.

Savitch, H. V. and Vogel, R. K. (2004, July). Suburbs without a city: power and citycounty consolidation. Urban Affairs Review, 39(6), 758-790.

Savitch, H. V., Vogel, R. K., and Ye, L. (2009). Beyond the rhetoric: lessons from Louisville's consolidation. The American Review of Public Administration, $X X(\mathrm{X}), 1-26$.

Sayer, A. (1984). Method in social science. London: Routledge.

Sayer, A. (1992). Method in social science: a realist approach (Second ed.). London: Routledge.

Sayer, A. (2000). Realism and social science. London: Sage.

Schiffer, H. B. (1970). Local administration and national development: fragmentation and centralization in Ghana. Canadian Journal of African Studies, 4(1), 57-76.

Schwieterman, J. (2006). Coalition politics at America's transportation hub. In J. P. Koval, L. Bennett, M. I. Bennett, F. Demissie, R. Garner, \& K. Kim (Eds.), The new Chicago: a social and cultural analysis (pp. 286-294). Philadelphia, PA: Temple University Press.

Schutt, R. K. (2012). Investigating the social world: the process and practice of research. Los Angeles, London, New Delhi, Singapore, and Washington, D. C.: SAGE.

Scott, A.J. (2001). Globalization and rise of city-regions. In N. Brenner \& R. Keil (Eds.), The global cities reader (pp. 370-376). London and New York: Routledge.

Selko, A. (2014). Chicago is new home of Digital Manufacturing and Design Innovation Institute. Retrieved from http://www.industryweek.com/innovation/chicago-newhome-digital-manufacturing-and-design-innovation-institute

Sellers, J. M. (2005). Re-placing the nation: an agenda for comparative urban politics. Urban Affairs Review, 40(4), 419-445. doi:10.1177/1078087404272673

Setterfield, M. (1993, September). A model of institutional hysteresis. Journal of Economic Issues, 27(3), 755-774.

Setterfield, M. (1995). Historical time and economic theory. Review of Political Economy, 7, 1-27. 
Setterfield, M. (1997). Rapid growth and relative decline: modelling macroeconomic dynamics with hysteresis. London: Macmillan.

Sheppard, E. (2002, July). The spaces and times of globalization: place, scale, networks, and positionality. Economic Geography, 78(3), 307-330.

Simpson, D. (2006). From Daley to Daley: Chicago politics 1955-2006. University of Illinois at Chicago, College of Liberal Arts and Sciences. Great Cities institute.

Sister Cities International. (2001-2012). 2014 membership directory. Retrieved from http://www.sister-cities.org/2014Directory

Sister Cities International. (2001-2012). Sister Cities International: mission and history. Retrieved March 19, 2013, from http://www.sister-cities.org/mission-and-history

Sister Cities International. (2013). Accra, Ghana. Retrieved from http://chicagosistercities.com/sister-cities/accra/

Smith, R. G. and Doel, M. A. (2011, January). Questioning the theoretical basis of current global city research: structures, networks, and actor-networks. International Journal of Urban and Regional Research, 35(1), 24-39. doi:10.1111/j.1468-2427.2010.00940.x

Societe Generale Ghana. (2014). The bank: history of the bank. Retrieved from $\mathrm{http} / / /$ societegenerale.com.gh/The-Bank/History-of-the-Bank.aspx

Squires, G. D.; Bennett, L.; McCourt, K.; and Nyden, P. (1987). Chicago: race, class, and the response to the urban decline. Philadelphia: Temple University Press.

Stone, C. N. (1987). The study of the politics of urban development. In C. N. Stone \& H. T. Sanders (Eds.), The politics of urban development. University Press of Kansas.

Stone, C.N. and Sanders, H.T. (1987). The politics of urban development. Lawrence, Kansas: University Press of Kansas.

Storper, M. (1997). The regional world: territorial development in a global economy. New York: The Guilford Press.

Suchar, C. S. (2006). The physical transformation of metropolitan Chicago: Chicago's central area. In J. P. Koval, L. Bennett, M. I. Bennett, F. Demissie, R. Garner, \& K. Kim (Eds.), The new Chicago: a social and cultural analysis (pp. 56-76). Philaddelphia, PA: Temple University Press.

Swanstrom, T. (1988). Semisovereign cities: the politics of urban development. Polity, 21(1), 83-110.

Swyngedouw, E. (2004). Globalisation or 'glocalisation'? Networks, territories and rescaling. Cambridge Review of International Affairs, 17(1), 25-48. 
Sydow, J., Lerch, F., and Staber, U. (2010). Planning for path dependence? The case of a network in the Berlin-Brandenburg optics cluster. Economic Geography, 86(2), 173-195.

Tarver, J. (1994). Urbanization in Africa: a handbook. Westport, Connecticut \& London: Greenwood Press.

Teaford, J. (2005). Government, suburban. Retrieved from The Electronic Encyclopedia of Chicago: http://www.encyclopedia.chicagohistory.org/pages/534.html

Tema Metropolitan Assembly. (n.d.). Tema: three zonal councils ready. Retrieved from http://tema.ghanadistricts.gov.gh/newsdetails.php?id=6527

Testa, W. A. (2004). A city reinvents itself. In C. Madigan (Ed.), Global Chicago (pp. 35-69). Urbana and Chicago: Chicago Council on Foreign Relations and the University of Illinois Press.

The Brookings Institution. (n. d.). The 10 traits of globally fluent metro areas: Chicago. Global Cities Initiative: A joint project of Brookings and J. P. Morgan Chase.

The Chicago Council on Global Affairs. (2011). Capturing Chicago's global opportunity: a memorandum from a global Chicago advisory committee.

The Chicago Council on Global Affairs. (n.d.). About us. Retrieved from http://www.thechicagocouncil.org/basic-page/about-us

The Chicago Council on Global Affairs. (n.d.). History. Retrieved from http://www.thechicagocouncil.org/basic-page/history

The Chicago Council on Global Affairs. (n.d.). "Publications". Retrieved from http://www.thechicagocouncil.org/publications? f[0]=sm_field_issue_link\%3Atax onomy term $\% 3 \mathrm{~A} 12$

The Commercial Club of Chicago. (2013). "History". Retrieved from http://www.commercialclubchicago.org/history

The World Bank. (2010). City of Accra, Ghana: consultative citizens' report card. The International Bank for Reconstruction and Development/The World Bank.

The World Bank Group. (2014). World Bank Group opens new office in Central Accra. Retrieved from http://www.worldbank.org/en/news/pressrelease/2013/08/13/world-bank-group-opens-new-office-in-central-accra

Thornley, A., Rydin, Y., Scanlon, K., and West, K. (2005, October). Business privilege and the strategic planning agenda of the Greater London Authority. Urban Studies, 42(11), 1947-1968.

Tsukamoto, T. and Vogel, R.K. (2007). Rethinking globalization: the impacts of central governments on world cities. In R. Hambleton, \& J. S. Gross (Eds.), Governing 
cities in a global era: urban innovation, competition, and democratic reform (pp. 15-31). New York: Palgrave Macmillan.

U. S. Census Bureau. (2013). Chicago-Naperville-Joliet, IL-IN-WI Metro Area. Retrieved from http://www.census.gov/econ/census/snapshots_center/chicago.html

U. S. Census Bureau. (2014). State and county quick facts: Chicago (city), Illinois. Retrieved from http://quickfacts.census.gov/qfd/states/17/1714000.html

Uitermark, J. (2002). Re-scaling, 'scale fragmentation' and the regulation of antagonistic relationships. Progress in Human Geography, 26(6), 743-765.

doi:10.1191/0309132502ph401oa

UNCTAD. (1999). World Investment Report.

UN Statistics. (2005). Definitions of "urban". Demographic Yearbook 2005. Retrieved from

http://unstats.un.org/unsd/demographic/sconcerns/densurb/Defintion_of\%20Urba n.pdf

UN-Habitat. (2008). The State of African Cities 2008: A Framework for Addressing Urban Challenges in Africa. United Nations Human Settlements Program (UNHabitat). Nairobi, Kenya: UNON: Publishing Services Section.

UN-HABITAT. (2008). The state of African cities 2008: a framework for addressing urban challenges in Africa. Retrieved from http://reliefweb.int/sites/reliefweb.int/files/resources/ADA68006EACB44434925 759000098F81-UN\%20habitat\%20african\%20cities.pdf

UN-Habitat. (2009). Ghana: Accra urban profile. Nairobi, Kenya: UNON, Publishing Services Section.

UN-Habitat. (2010). The state of African cities 2010: governance, inequality, and urban labor markets. United Nations Human Setttlements Program (UN-Habitat). Nairobi, Kenya: UNON: Publishing Services Section.

U. S. Census Bureau. (2015). Foreign trade. Retrieved from http://www.census.gov/foreign-trade/

U. S. Department of State: Office of Website Management, Bureau of Public Affairs. (n.d.). Chicago, IL. Retrieved from http://www.state.gov/ofm/ro/ch/

United Nations. (n. d.). We can end poverty: Millennium Development Goals and beyond 2015. Retrieved from http://www.un.org/millenniumgoals/

U. S. Department of Energy Office of Science: UChicago Argonne LLC. (n.d.). Retrieved from http://www.anl.gov/about-argonne 
Visser, J. A. (2002, March). Understanding local government cooperation in urban regions: toward a cultural model of inter-local relations. American Review of Public Admnistration, 32(1), 40-65.

Vogel, R. K. (2010). Governing global city regions in China and the West. In R. K. Vogel, H. V. Savitch, J. Xu, A. G. Ye, W. Wu, A. Sancton, ... P. Newman, Governing global city regions in China and the West (Vol. 73, pp. 1-75). Progress in Planning.

Wallis, A. D. (1994). Inventing regionalism: a two-phase approach. National Civic Review, 83(4), 447-468.

Wallis, A. D. (1994, Spring/Summer). Inventing regionalism: The first two waves. National Civic Review, 83(2), 159-175.

Wallis, A. D. (1994, Summer/Autumn). The third wave: current trends in regional governance. National Civic Review, 83(3), 290-310.

Wallis, A. D. (1994, Winter/Spring). Evolving structures and challenges of metropolitan regions. National Civic Review, 83(1), 40-53.

Warner, S. B. (1987). The private city: Philadelphia in three periods of its growth (Second ed.). Philadelphia: University of Pennsylvania Press.

Wei, Y.D., Leung, C.K., and Luo, J. (2006). Globalizing Shanghai: foreign investment and urban restructuring. Habitat International, 30, 231-244.

Wells, G. (2001). The issue of globalization: an overview. Cornell University ILR School.

Wheeler, S. (2002, Summer). The new regionalism: key characteristics of an emerging movement. Journal of the American Planning Association, 68(3), 267-278.

White, J. W. (1998). Old wine, cracked bottle?: Tokyo, Paris, and the global city hypothesis. Urban Affairs Review, 33(4), 451-477. doi:10.1177/107808749803300401

Wiewel, W. \& Persky, J. J. (Eds.). (2002). Suburban sprawl: private decisions and public policy. Armonk, New York and London, England: M. E. Sharpe.

WISERTrade. (2013). World Institute for Strategic Economic Research. Retrieved from http://www.wisertrade.org/home/portal/index.jsp

Wolfson, J. and Frisken, F. (2000). Local response to the global challenege: comparing local economic development policies in a regional context. Journal of Urban Affairs, 22(4), 361-384.

Wollmann, H. (2004, March). Urban leadership in German local politics: the rise, role and performance of the directly elected (chief executive) mayor. International Journal of Urban and Regional Research, 28(1), 150-165. 
World Business Chicago. (2010). "About". Retrieved from http://www.worldbusinesschicago.com/about

World Business Chicago. (2010). Chambers of commerce. Retrieved from http://www.worldbusinesschicago.com/services/resources/chambers-of-commerce

World Business Chicago. (2010). Chicago area foreign business, investment, and international trade organizations. Retrieved from http://www.worldbusinesschicago.com/services/resources/international-orgs

World Business Chicago. (2010). ChicagoNEXT. Retrieved from http://www.worldbusinesschicago.com/chicagonext

World Business Chicago. (2010). Consulates and international offices. Retrieved from http://www.worldbusinesschicago.com/data/international/consulates

World Business Chicago. (2010). Get the data. Retrieved from http://www.worldbusinesschicago.com/data

World Business Chicago. (2012). A plan for economic growth and jobs: executive summary. World Business Chicago.

World Business Chicago. (2012). City of Chicago.

World Business Chicago. (2012). Downtown Chicago.

World Business chicago. (2012). Top 10 metro areas for manufacturing.

World Business Chicago. (2012, 2011, and 2010). Chicago's business growth profile: new and expanded companies.

World Business Chicago. (2013). Business services: Chicago area.

World Business Chicago. (2013). Chicago by the numbers.

World Business Chicago. (2013). Chicago colleges and universities research and development expenditures.

World Business Chicago. (2013). Chicago fortune 500 headquarters, 2013.

World Business Chicago. (2013). Chicago gross regional product.

World Business Chicago. (2013). Chicago is home to 17\% of worldwide derivatives trading.

World Business Chicago. (2013). Chicago major trade partners, 2012.

World Business Chicago. (2013). Chicago research and development facilities.

World Business Chicago. (2013). Chicago top commodity exports and imports by value.

World Business Chicago. (2013). Chicago's fastest growing companies. 
World Business Chicago. (2013). Financial exchange employees by metro area, 2013.

World Business Chicago. (2013). Financial services: Chicago Area.

World Business Chicago. (2013). Great Lakes and St. Lawrence Region: 2013 economic profile update.

World Business Chicago. (2013). High tech: Chicago area.

World Business Chicago. (2013). Information technology: Chicago area.

World Business Chicago. (2013). Largest companies: all sectors - headquarters presence in Chicago.

World Business Chicago. (2013). Manufacturing: Chicago area.

World Business Chicago. (2013). Top 10 metro areas for business services.

World Business Chicago. (2013). Top 10 metro areas for financial services.

World Business Chicago. (2013). Top 10 metro areas for high tech sectors.

World Business Chicago. (2013). Top 10 metro areas for information technology.

World Business Chicago. (2013). Top global derivatives exchanges by number of contracts.

World Business Chicago. (2014). Chicago foreign direct investment. Chicago FDI Sheet EN 102014.

World Business Chicago. (2014). Chicago international connections and strengths. Chicago FDI Sheet EN 102014.

World Business Chicago. (2014). Chicago's competitive advantages for business: North America's global corporate hub.

World Business Chicago. (2015). ChicagoNEXT. Retrieved from http://www.worldbusinesschicago.com/chicagonext/

World Business Chicago. (n.d.). Chicago's business climate.

World Economic Forum. (2015). The global competitiveness report, 2014-2015. World Economic Forum.

World Trade Center Accra. (2014). History of World Trade Center Accra. Retrieved from http://www.wtcaccra.com/about-us/history

Wrigley Jr. Company. (2012). Global Innovation Center. Retrieved from http://www.wrigley.com/global/about-us/global-innovation-center.aspx

Wrigley Jnr. Company. (2012). Wrigley: a subsidiary of Mars Incorporated. Retrieved from http://www.wrigley.com/global/about-us.aspx 
Wu, F. (2000). Place promotion in Shanghai, PRC. Cities, 17(5), 349-361.

Wu, F. (2003). Globalization, place promotion and urban development in Shanghai. Journal of Urban Affairs, 25(1), 55-78.

Yeboah, I. E. A. (2000, Spring). Structural adjustment and emerging urban form in Accra, Ghana. Africa Today, 47(2), 61-89.

Yeung, H. W.-C. (1997). Critical realism and realist research in Human Geography: a method or a philosophy in search of a method? Progress in Human Geography, 21(1), 51-74. doi:10.1191/030913297668207944

Yeung, H. W.-C. (2002, July). The limits to globalization theory: a geographic perspective on global economic change. Economic Geography, 78(3), 285-305.

Yin, R. (2014). Case study research: design and methods (Fifth ed.). Los Angeles, London, New Delhi, Singapore, and Washington DC: SAGE Publications, Inc.

Zhang, Y. (2013). The fragmented politics of urban preservation: Beijing, Chicago, and Paris (Vols. Globalization and Community, Volume 22). Minneapolis and London: University of Minnesota Press.

Zhao, X. B. and Zhang, L. (1999). Decentralization reforms and regionalism in China: a review. International Regional Science Review , 22(3), 251-281. doi:10.1177/016001799761012424 
Appendix I: Interviews for the City-Region of Chicago, Illinois

\section{Interview Questions: Chambers of Commerce, Foreign/Trade Missions, and Related Bodies}

(Note: The city-region of Chicago here refers to the Chicago metro Area comprising Cook, DuPage, Kane, McHenry, Lake, and Will counties)

1. How important is globalization to the city-region of Chicago? How eager is the cityregion to be global? What are some distinguishing attributes which make Chicago stand out as a global city-region?

2. How important is foreign direct investment towards the development of Chicago? Please talk about some reasons for the level of importance you attach to foreign direct investment. How does foreign direct investment help to boost the status of Chicago as a global city-region?

3. Given the level of importance you attach to foreign direct investment, please state some measures you have put in place over the years to attract or discourage investment in the city-region of Chicago? What have been the roles of the mayors of Chicago and other officials (e.g. county, state, and federal level officials, officials from planning bodies etc.) in promoting or hindering foreign direct investment?

4. How important is the service sector towards the development of Chicago? Please talk about some reasons for the level of importance you attach to the service sector. How does the growth of the service sector help to enhance the status of Chicago as a global cityregion?

5. Given the level of importance you attach to the service sector, what measures (if any) have you put in place over the years to promote (or hinder) the growth of this sector? What have been the roles of the mayors of Chicago and other officials (e.g. county, state, and federal level officials, officials from planning bodies etc.) in promoting or hindering the growth of the service sector? 
6. How important is international trade (i.e. imports and exports) to the development of Chicago? How does international trade help to enhance the status of Chicago as a global city-region? What measures (if any) have you put in place over the years to promote international trade in the city-region? What, if any, have been the roles of the mayors of Chicago and other officials (e.g. county, state, and federal level officials, officials from planning bodies etc.) in promoting or hindering international trade?

7. How important is trade in portfolio assets (i.e. bonds, stocks, shares, equities etc.) to the development of Chicago? How does trade in portfolio assets help to boost the status of Chicago as a leading global city-region? What measures (if any) have you put in place over the years to promote trade in portfolio assets within the city-region?

8. How do the presence of chambers of commerce, foreign consulates, trade missions etc. (such as yours), help to boost the status of Chicago as a global city-region?

9. How important are liberal economic policies (e.g. privatization, public-private partnerships etc.) to the development of Chicago? Please explain the reasons for the level of importance you attach to these policies. How do liberal economic policies help to boost the status of Chicago as a global city-region?

10. What are some of the measures you have put in place over the years to either promote or hinder liberal economic policies in the city of Chicago? What have been the roles of the mayors of Chicago and other officials (e.g. county, state, and federal level officials, officials from planning bodies etc.) in promoting or hindering liberal economic policies in the city-region?

11. How do the presence of Fortune 500 companies and other firms/investors help to promote the status of Chicago as a leading global city-region? What measures (if any) have you put in place over the years to attract investments from these firms to the cityregion? What have been the roles of the mayors of Chicago and other officials (e.g. county, state, and federal level officials, officials from planning bodies etc.) in attracting investments from these firms?

12. What aspect(s) of the business and political environments in Chicago (e.g. economic indicators, taxes, subsidies, infrastructure, institutions, political leadership, nature of governance, local government cooperation etc.) make firms/investors like doing business in the city-region? What aspect(s) of the business and political environments in Chicago make firms/investors dislike doing business in the city-region? 


\section{Interview Questions: Metro Government(s), Government Agencies, and Planning Bodies}

(Note: The city of Chicago here refers to the Chicago metro Area comprising Cook, DuPage, Kane, McHenry, Lake, and Will counties)

1. How best would you describe the nature of metro governance in Chicago? Decentralized? Centralized? A hybrid model? Please explain your response.

2. Please talk about the history of decentralization in Chicago. How does the nature of metro governance in Chicago today compare with the situation which prevailed in the:

(i) $2000 \mathrm{~s}$

(ii) $1990 \mathrm{~s}$

(iii) $1980 \mathrm{~s}$

3. What primary factor(s) [e.g. political, historical, cultural, economic etc.] explain the nature of metro governance in Chicago? Please elaborate. Please talk about the roles of the mayors of Chicago and other officials (e.g. county, state, and federal level officials, officials from planning bodies etc.) in the metro governance of the city. Have these roles changed over the years? If yes, how and why? If no, why not?

4. What are some of the challenges (e.g. bureaucracy, duplication of roles etc.) associated with metro governance in Chicago? Please talk about some measures, if any, which have been taken over the years to address these challenges.

5. Do localities in the city of Chicago collaborate? If yes, why? In what ways do the localities cooperate? If no, why not? In what ways do the localities refuse to collaborate? What is the legal framework, if any, which governs cooperation among localities (or the absence of cooperation among localities) in Chicago?

6 (a) What are the roles of the following entities in promoting (or discouraging) cooperation among the various localities?

(i) Chicago Metro Government (e.g. Mayor's office etc.) 
(ii) Planning and government agencies (e.g. Metropolitan Planning Council, Chicago Metro Agency for Planning, this particular planning body etc.)

(iii) County governments

(iv) State Government of Illinois

(v) United States Federal Government

(b) What are the roles of the following people in promoting (or discouraging) cooperation among the various localities in Chicago?

(i) The mayors of the city

(ii) Other officials (e.g. county, state, and federal-level officials, officials in planning bodies etc.)

7. What are the benefits of cooperation (or the absence of cooperation) for the various localities in particular and the city-region of Chicago in general? What are the disadvantages or costs of cooperation (or the absence of cooperation) for the various localities in particular and the city-region of Chicago in general?

8. How does cooperation among localities (or the absence of cooperation among localities) in Chicago today compare with the situation which prevailed in the:

(a) $2000 \mathrm{~s}$

(b) $1990 \mathrm{~s}$

(c) $1980 \mathrm{~s}$

9. How important are the public and private sectors, respectively, towards the development of Chicago? Please explain the reasons for the level of importance you attach to these sectors.

10. How important are liberal economic policies (e.g. privatization, public-private partnerships etc.) to Chicago? Please explain the reasons for the level of importance you attach to these policies. What are some of the measures you have put in place over the years to either promote or hinder liberal economic policies? What have been the roles of 
the mayors of Chicago and other officials (e.g. county, state, and federal level officials, officials from planning bodies etc.) in promoting or hindering these policies?

11. How important is foreign direct investment towards the development of Chicago? Please talk about some reasons for the level of importance you attach to foreign direct investment. How does foreign direct investment help to boost the status of Chicago as a global city?

12. Given the level of importance you attach to foreign direct investment, please state some measures you have put in place over the years to attract or discourage investment in the city of Chicago? What have been the roles of the mayors of Chicago and other officials (e.g. county, state, and federal level officials, officials from planning bodies etc.) in promoting or hindering foreign direct investment? 
Appendix II: Interviews for Accra, Ghana

Interview Questions: Chambers of Commerce, Foreign/Trade Missions, and Related Bodies

(NB: The city of Accra here refers to the Greater Accra metro area comprising the AMA, TMA, Ashaiman, Ga Districts, Ledzokuku-Krowor, La-Dadekotopon, La-NkwantanangMadina, and Adentan)

1. How important is globalization to the city of Accra? How eager is the city to be integrated into the global economy? What are some distinguishing attributes which make Accra stand out as a globalizing city?

2. How important is foreign direct investment towards the development of Accra? Please talk about some reasons for the level of importance you attach to foreign direct investment. How does foreign direct investment help to boost the role of Accra within the global economy?

3. Given the level of importance you attach to foreign direct investment, please state some measures you have put in place over the years to attract or discourage investment in the city of Accra? What have been the roles of the mayors of Accra and other officials (e.g. government officials, officials from metropolitan/municipal/district assemblies and planning bodies etc.) in promoting or hindering foreign direct investment?

4. How important is the service sector (e.g. banking and finance, insurance, accounting, law etc.) towards the development of Accra? Please talk about some reasons for the level of importance you attach to the service sector. How does the growth of the service sector help to enhance the role of Accra within the global economy? 
5. Given the level of importance you attach to the service sector, what measures (if any) have you put in place over the years to promote (or hinder) the growth of this sector? What have been the roles of the mayors of Accra and other officials (e.g. government officials, officials from metropolitan/municipal/district assemblies and planning bodies etc.) in promoting or hindering the growth of the service sector?

6. How important is international trade (i.e. imports and exports) to the development of Accra? How does international trade help to enhance the role of Accra within the global economy? What measures (if any) have you put in place over the years to promote international trade in the city-region? What, if any, have been the roles of the mayors of Accra and other officials (e.g. government officials, officials from metropolitan/municipal/district assemblies and planning bodies etc.) in promoting or hindering international trade?

7. How important is trade in portfolio assets (i.e. bonds, stocks, shares, equities etc.) to the development of Accra? How does trade in portfolio assets help to boost the role of Accra within the global economy? What measures (if any) have you put in place over the years to promote trade in portfolio assets within the city-region?

8. How do the presence of chambers of commerce, foreign consulates, trade missions etc. (such as yours), help to boost the role of Accra within the global economy?

9. How important are liberal economic policies (e.g. privatization, public-private partnerships etc.) to the development of Accra? Please explain the reasons for the level of importance you attach to these policies. How do liberal economic policies help to boost the role of Accra within the global economy?

10. What are some of the measures you have put in place over the years to either promote or hinder liberal economic policies in the city of Accra? What have been the roles of the mayors of Accra and other officials (e.g. government officials, officials from metropolitan, municipal, or district assemblies and planning bodies etc.) in promoting or hindering liberal economic policies in the city-region?

11. How do the presence of Ghana Club 100 companies, foreign firms, and other investors help to role of Accra within the global economy? What have been the roles of the mayors of Accra and other officials (e.g. government officials, officials from metropolitan, municipal, or district assemblies and planning bodies etc.) in attracting investments from these firms? 
12. What aspect(s) of the business and political environments in Accra (e.g. economic indicators, taxes, subsidies, infrastructure, institutions, political leadership, nature of governance, local government cooperation etc.) make firms/investors like doing business in the city? What aspect(s) of the business and political environment in Accra make firms/investors dislike doing business in the city? 


\section{Interview Questions: Metro Government(s), Government Agencies, and Planning Bodies}

(NB: The city of Accra here refers to the Greater Accra metro area comprising the AMA, TMA, Ashaiman, Ga Districts, Ledzokuku-Krowor, La-Dadekotopon, La-NkwantanangMadina, and Adentan)

1. How best would you describe the nature of metro governance in Accra? Decentralized? Centralized? A hybrid? Please explain your response.

2 (a) Please talk about Ghana's decentralization programme. Why was it embarked upon? What have been some of the successes and failures? Why were new districts created in 2004 and 2012 (in addition to the ones originally created under the decentralization programme)?

(b) How does the nature of metro governance in Accra today compare with the situation which prevailed in the:

(i) $2000 \mathrm{~s}$

(ii) $1990 \mathrm{~s}$

(iii) $1980 \mathrm{~s}$

3. What primary factor(s) [e.g. political, historical, cultural, economic etc.] explain the nature of metro governance in Accra? Please elaborate. Please talk about the roles of the mayors/chief executives and other officials (from this and the various metropolitan/municipal/district assemblies) in the metro governance of Accra. Have these roles changed over the years? If yes, how and why? If no, why not? 
4. What are some of the challenges (e.g. bureaucracy, duplication of roles, financial limitations etc.) associated with metro governance in Accra? Please talk about some measures, if any, which have been taken over the years to address these challenges.

5. Do assemblies/sub-metros in Accra cooperate? If yes, why? In what ways do they collaborate? If no, why not? In what ways do these assemblies/sub-metros refuse to cooperate? What is the legal framework, if any, which governs cooperation (or the absence of cooperation) among assemblies/sub-metros in Accra?

6 (a) What are the roles of the following entities in promoting (or discouraging) cooperation among the various assemblies/sub-metros (or lower levels of government)?

(i) This metropolitan/municipal/district assembly and other assemblies

(ii) Planning bodies (e.g. Town and Country Planning Department etc.)

(iii) The Greater Accra Regional Coordinating Council

(iv) The Ministry of Local Government and Rural Development

(iv) The Central Government (i.e. Government of Ghana)

(b) What are the roles of the following people in promoting (or discouraging) cooperation among the various assemblies/sub-metros (or lower levels of government)?

(i) The mayor(s)/chief executive(s) of this and other assemblies

(ii) Other government officials (e.g. Greater Accra Regional Minister, Minister of Local Government and Rural Development etc.)

7. What are the benefits of cooperation (or the absence of cooperation) for the various assemblies/sub-metros in particular and the city of Accra in general? What are the disadvantages or costs of cooperation (or the absence of cooperation) for the various assemblies/sub-metros in particular and the city of Accra in general? 
8. How does cooperation (or the absence of cooperation) among assemblies/sub-metros in Accra today compare with the situation which prevailed in the:

(a) $2000 \mathrm{~s}$

(b) $1990 \mathrm{~s}$

(c) $1980 \mathrm{~s}$

9. How important are the public and private sectors respectively towards the development of Accra? Please explain the reasons for the level of importance you attach to these sectors.

10. How important are liberal economic policies (e.g. privatization, public-private partnerships etc.) to Accra? What are some of the measures you have put in place over the years to either promote or hinder liberal economic policies? What have been the roles of the mayors/chief executives (of this and other assemblies), as well as other officials (e.g. government ministers etc.) in promoting or hindering these policies?

11. How important is foreign direct investment towards the development of Accra? Please talk about some reasons for the level of importance you attach to foreign direct investment. How does foreign direct investment help to boost the status of Accra as a globalizing city?

12. Given the level of importance you attach to foreign direct investment, please state some measures you have put in place over the years to attract or discourage investment in the city of Accra? What have been the roles of the mayors of Accra and other officials (e.g. government officials, officials from metropolitan/municipal/district assemblies and planning bodies etc.) in promoting or hindering foreign direct investment? 


\section{CURRICULUM VITAE}

\section{ERIC YANKSON}

426 West Bloom Street

Department of Urban and Public Affairs, University of Louisville, Louisville, KY 40208.
Phone (+1) 502 - 852-8961

Email: eric.yankson@louisville.edu

\section{Education}

- Doctor of Philosophy, Urban and Public Affairs (Urban Planning and Development; Public Policy and Administration), University of Louisville August, 2015

- Master of Science, Geography (Regional, Environmental, and Urban Planning), University of Alabama - December, 2011

- Certificate, Geographical Information Systems (GIS), University of Alabama - September, 2010

- Bachelor of Arts (Honors), Economics and Geography \& Resource Development, University of Ghana-Legon - May, 2006

- Presbyterian Boys' Secondary School-Legon (General Arts: Economics, Geography, and Elective Mathematics) - December, 2000

\section{Research and Teaching Interests}

- Regional and Urban Governance; Urban Policy and Management; Political Economy

- International Relations and Development; Globalization and Geopolitics

- Comparative and Economic Development; Development Policy and Planning; Housing and Community Development 
- Land Use and Transportation Planning; Sustainability; Planning Theory; GIS and Applied Statistics

- Program Evaluation; Policy Analysis; Research Methods; Non-profits; Public Management and Organizational Theory

\section{Key Skills and Competencies}

- Excellent Research and Teaching Skills

- Outstanding Writing, Communication, and Interpersonal Skills

- Commitment to Service and Excellence

- Broad-based and Interdisciplinary Training: Urban Planning and Development, Public Policy and Administration, Geography, Economics, and Applied Statistics

- Languages: English (Very Fluent); Akan (Fluent); French/Spanish (Elementary Knowledge)

\section{Academic Awards/Honors}

- Honoree, Graduate Students' Dean's Receptions - University of Louisville (April 24, 2015 and April 22, 2014)

- Honoree, Graduate Students' Celebration of Excellence in Diversity Event (April 24, 2015)

- Graduate Fellow, Department of Urban and Public Affairs - University of Louisville (August, 2011 to date)

- Member, Golden Key International Honour Society 
- American Planning Association (APA)

- Urban Affairs Association (UAA)

- American Society for Public Administration (ASPA)

- South Eastern Division of the Association of American Geographers (SEDAAG)

\section{Computer/Software Literacy}

- Microsoft Office (Word, Excel, Powerpoint, and Access)

- ArcGIS \&ArcMap

- ERDAS Imagine

- Adobe Illustrator \& Photoshop

- Statistical Package for Social Sciences (SPSS)

- Statistical Analysis System (SAS)

- Analysis of Moment Structures (AMOS)

\section{Experience}

- Graduate Research Assistant (Department of Urban and Public Affairs University of Louisville: July, 2013 to July, 2015)

- Undertaking various research projects with assigned faculty

- Collating and analyzing census data

- Carrying out GIS and statistical modeling exercises

- Political Economy Course Instructor (Department of Political Science University of Louisville: Fall, 2014)

○ Teaching Urban Political Economy (An undergraduate level third year course) 
- Participant, Graduate Teaching Academy (School of Interdisciplinary and Graduate Studies, University of Louisville: September, 2014 to April, 2015)

- Learning classroom management and assessment techniques

○ Acquiring expertise on learner-centered teaching

- Participant, Entrepreneurship Academy (School of Interdisciplinary and Graduate Studies, University of Louisville: September to December, 2014)

- Acquiring expertise on social entrepreneurship, business model canvass, and lean launch pad

- Participant, 2013/2014 Grant Writing Academy (School of Interdisciplinary and Graduate Studies, University of Louisville: September, 2013 to January, 2014)

- Learning about the structure and general rubrics of writing a research grant proposal

○ Learning techniques in post grant award management

- Graduate Teaching Assistant (Department of Geography, University of Alabama: January, 2009 to May, 2011)

○ Teaching Physical Geography during lab hours

- Assisting assigned faculty

- Intern (Geological Survey of Alabama: May to August, 2010)

$\circ$ Performing data entry and ArcGIS digitization tasks

- Tutor (Campus Athletics and Student Services, University of Alabama: June to July 2009 \& 2011)

○ Teaching student athletes World Regional Geography and Climatology

\section{Extra-Curricular Activities}

- Member, Urban \& Public Affairs Ph.D. Students' Association - University of Louisville (August, 2011 to July, 2015)

- Member, African Students' Union - University of Louisville (August, 2011 to July, 2015)

- Member, OASIS: A students' group which engages in service projects University of Louisville (August, 2011 to July, 2015) 
- Treasurer, African Students' Association - University of Alabama (August, 2010 to July, 2011)

- Vice President, PANORAMA: A students' group involved in community service projects - University of Alabama (August, 2010 - July, 2011)

- Member, Club Geography - University of Alabama (August, 2010 to July, 2011)

\section{Conference Presentations (Selected)}

- Globalization and Local Factors in Cities: An Examination (Paper presented at the 2015 Conference of the Urban Affairs Association)

- Globalization, Inter-Local Cooperation, and Urban Governance: A Comparative Case Study Analysis (Paper presented at the 2014 Conference of the Urban Affairs Association)

- The Ecological Paradigm in Urban Development: Implications for Sustainability (Paper presented at the 2013 Conference of Urban and Metropolitan Universities)

- Analyzing Regional Development Policy: A Comparative Case Study Approach (Research presented at the 2013 Annual Meeting of the Indiana Political Science Association)

\section{Conferences Attended (Selected)}

- 2015 Conference of the Urban Affairs Association, Miami - Florida (April 811, 2015)

- 2014 Conference of the Urban Affairs Association, San Antonio - Texas (March 19-22, 2014)

- 2013 Conference of Urban and Metropolitan Universities, Louisville, Kentucky (October 27-29, 2013)

- 2013 Annual Meeting of the Indiana Political Science Association, Evansville (March 22, 2013) 
- 2011 Southern Cities' Conference, Jackson State University, Mississippi (March 25-26, 2011)

- 2010 Conference of the South Eastern Division of the Association of American Geographers, Birmingham - Alabama (November 21-23, 2010).

- 2009 Geospatial Conference, Huntsville - Alabama (November 17, 2009).

\section{Referees}

- Hank V. Savitch, Ph.D.

Emeritus Brown and Williamson Distinguished Research Professor

Department of Urban and Public Affairs

University of Louisville

hank.savitch@louisville.edu

(+1) $502-533-5465$

- Steven G. Koven, Ph.D.

Professor

Department of Urban and Public Affairs

University of Louisville

steven.koven@louisville.edu

(+1) $502-852-8257$

- Margath Walker, Ph.D.

Assistant Professor

Department of Geography and Geosciences

University of Louisville

margath.walker@louisville.edu

(+1) $502-852-2694$ 
- Charles E. Ziegler, Ph.D.

Professor and Distinguished University Scholar

Department of Political Science

University of Louisville

charles.ziegler@louisville.edu

(+1) $502-852-3248$

- Steven C. Bourassa, Ph.D.

Professor and Director,

School of Urban and Regional Planning

Florida Atlantic University

sbourassa@fau.edu

(+1) $561-297-4279$ 